\title{
SINTOMATOLOGIA DAS CARENCIAS DE MACRONUTRIENTES EM CASA DE VEGETAÇÃO E RECRUTAMENTO DE NUTRIENTES PELO FREIJÓ (Cordia goeldiana, HUBER) AOS 2, 3, 4 E 8 ANOS DE IDADE IMPLANTADO EM LATOSSOLO AMARELO DISTRÓFICO, BELTERRA, PARÁ
}

DILSON AUGUSTO CAPUCHO FRAZÃO

Engenhoiro Agrônomo

Orientador: Prof. Dr. RONALDO IVAN SILVEIRA

Tese apresentada à Escola Superior de Agricultura "Luiz de Queiroz", da Universidade de São Paulo, para obtenção do título de Doutor em Agronomia. Área de Concentração: Solos e Nutrição de Plantas.

PIRACICABA

Estado de São Paulo - Brasil

Março - 1985 
A meu prezado tio e

amigo Humberto Frazão por tudo que

representou na minha formação, pela

experiência e conselhos transmitidos, e principalmente pela saudade deixada, minha

HOMENAGEM (in memoriam)

A meus pais,

com admiração, respeito e orgulho.

A minhas irmãs,

com gratidão e carinho.

A minha esposa e fllhos,

pelo amor, dedicação, compreensão

$e$ incentivos constantes. 


\section{AGRADECIMENTOS}

Ao Prof. Dr. Ronaldo Ivan Silveira, pela orientação, estimulo e amizade, importantes na execução deste trabalho.

Aos Drs. Antonio Paulo Mendes Galvão e Carlos Alberto Ferreira pelo incentivo, apoio e consideração.

Ao Prof. Dr. Walter de Paula Lima pelas facilidadescon cedidas na anālise química de plantas.

Ao Dr. Ubaldino Dantas Machado pela consideração, ami zade e ajuda na produção do material fotogrä́fico.

Aos Profs. Drs. José Renato Sarruge, Henrique Paulo Hag e Antonio Augusto Lucchesi pela colaboração e sugestões.

Aos colegas Lourival Ferreira Cavalcante, José Holanda Campelo Junior, Rui de Amorim Carvalho, Moacyr Bermardino Dias Filho, Noemi Vianna Martins Leão e Jorge Alberto Gazel Yared pela colaboração prestada e aos demais colegas do Curso de Pós - Gra duação pelo convívio e amizade.

As Bibliotecárias Rosa Edite Pedreira eMarialice Metzker Poggiani pela valiosa ajuda e atenção dispensada.

Aos funcionārios Luiz Carlos Veríssimo, Mário Benedi to Ludovico e Izabel Cristina Gava daESALQ, Magali Aparecida de Oliveira do IPEF, Cleusa Cabral Pereira do CENA, Paulo Cézar Modesto de Barros, Ruth Rendeiro Palheta e Maria José Rodrigues dos Santos do CPATU/EMBRAPA, pela colaboração prestada.

Aos funcionários do Campo Experimental de Belterra (CPATU/EMBRAPA) pela colaboração na coleta do material vegetal no campo. 
A minha esposa Ana Izabel, pelo estímulo espiritual, incentivo e compreensão em todos os momentos.

A família Ignatti pela amizade sincera, acolhida e mo mentos inesquecíveis vividos durante a realização do Curso.

A Empresa Brasileira de Pesquisa Agropecuária - EMBRA PA e em especial ao Centro de Pesquisa Agropecuária do Trópico Jmido - CPATU pela oportunidade de aperfeiçoamento.

A Escola Superior de Agricultura "Luiz de Queiroz", da Universidade de São Paulo, pelas facilidades concedidas.

A todos aqueles que, de alguma forma, contribuiram posi tivamente na realização deste trabalho,

o autor reconhecidamente agradece. 


\section{INDTCE}

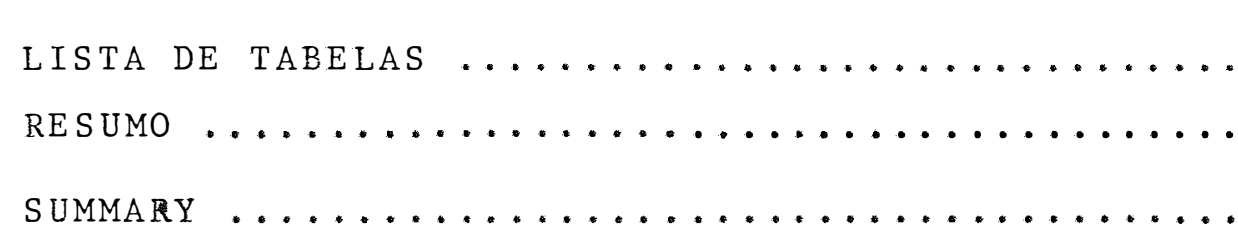

Pàgina

vii

xvii

xxii

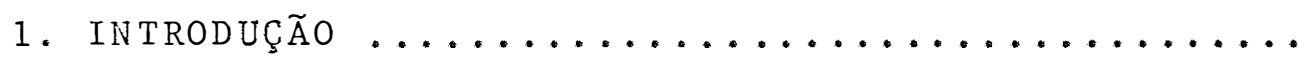

2. REVISÃO DE LiteratuRA ......................... 5

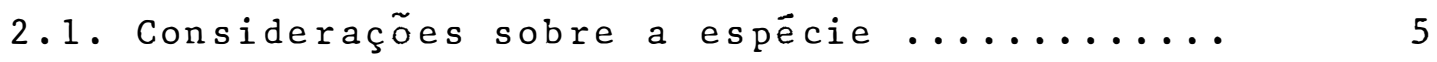

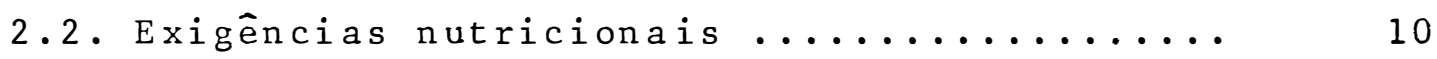

2.2.1. Concentração de nutrientes ........ 11

2.2.2. Extração de nutrientes .......... 33

2.2.3. Sintomas de deficiências nutricionais. 41

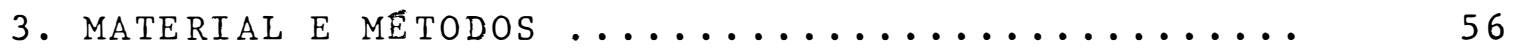

3.1. Experimento em casa de vegetação ......... 56

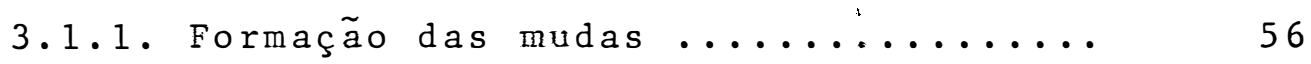

3.1.2. Observações, colheita e preparo para

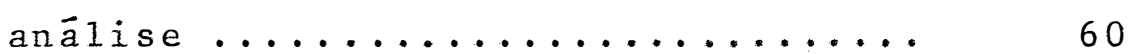

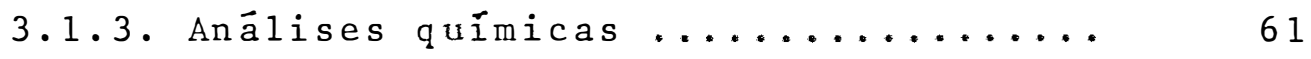

3.1.4. Planejamento experimental e anāiises estatisticas ............... 62

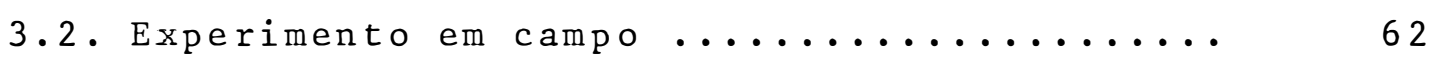

3.2.1. Localização e caracterização da área 63

3.2.2. Seleção do material e coleta das anos $\operatorname{tras} \ldots \ldots \ldots \ldots \ldots \ldots \ldots \ldots \ldots . \ldots \ldots 6 . \ldots \ldots$

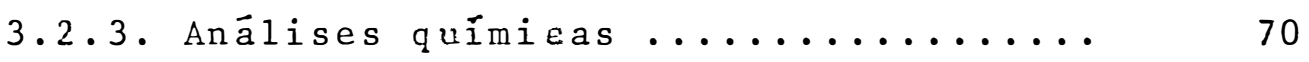

3.2.4. Planejamento experimental e anālises

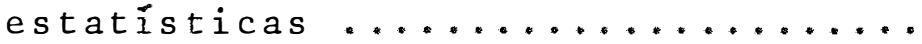

4. RESUltados E Discuss $\tilde{O} 0 \ldots \ldots \ldots \ldots \ldots \ldots \ldots \ldots$

4.1. Experimento em casa de vegetação ......... 72 
vi.

Pägina

4.1.1. Sintomas de deficiência .......... 72

4.1.2. Desenvolvimento das plantas ....... 85

4.1.3. Concentração de nutrientes ........ 89

4.1.4. Níveis de nutrientes ............. 110

4.2. Experimento em campo .................. 113

4.2.1. Desenvolvimento das plantas ....... 113

4.2.2. Macronutrientes ................ 117

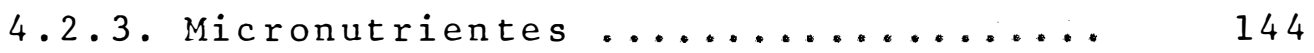

4.2.4. Concentração e quantidades de nutrientes acumuladas nas diversas partes e na planta inteira em função das ida

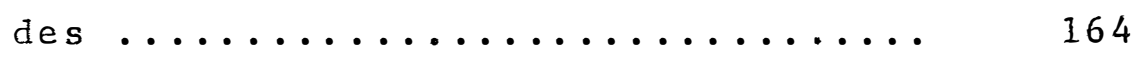

4.2.5. Exportação de nutrientes ......... 174

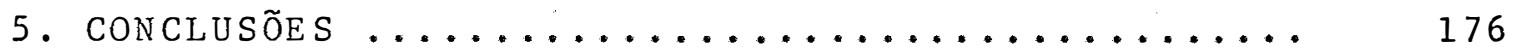

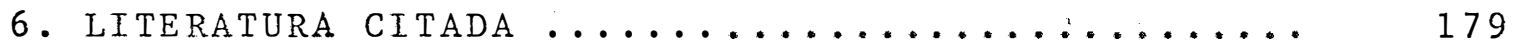




\section{LISTA DE TABELAS}

Tabela n?

01. Composição química das soluções nutritivas (ml/1)

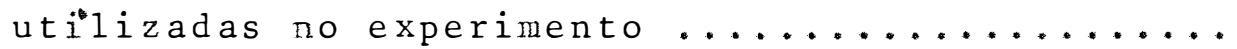

02. Médias mensais e anuais para precipitação pluvial (PP), temperatura mínima (Tm), temperatura média compensada ( $\overline{\mathrm{T}})$, temperatura máxima (TM), umidade relativa do ar (UR) e insolação (INS) para as con dições do Campo Experimental de Belterra, municí pio de Santarém - Estado do Pará (Período 1974/83).

03. Resultados das anāilses química e granulométrica de um perfil representativo da área experimental (Laboratório de Solos do CPATU/EMBRAPA)........ 66

04. Resultados das anālises químicas do solo ( $20 \mathrm{~cm}$ ) em amostras coletadas em áreas de populações com

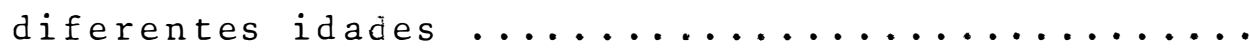

05. Resultados da anālise da composição textural do solo $(20 \mathrm{~cm})$ em amostras coletadas em äreas de

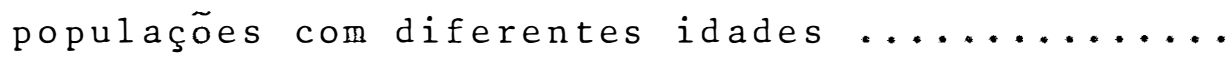

06. Peso da matéria seca (g/planta) total e das diver sas partes da planta cultivada em solução nutriti va, em função dos tratamentos e resumo da análise de variância (Média de 4 repetições)...........

07 . Teor percentual de nitrogênio contido na matéria seca das diversas partes da planta cultivada em solução nutritiva, em função dos tratamentos e re sumo da anālise de variância (Média de 4 repetí

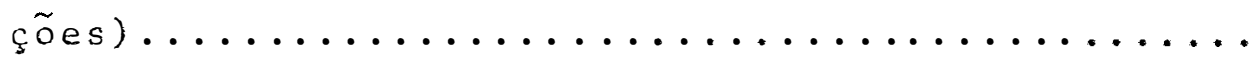


08. Teor percentual de fósforo contido na matéria se ca das diversas partes da planta cultivada em so lução nutritiva, em função dos tratamentos e re sumo da anālise de variância (Média de 4 repetí

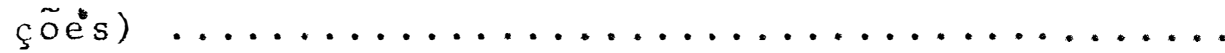

09. Teor percentual de potássio contido na matéria seca das diversas partes da planta cultivada em solução nutritiva, em função dos tratamentos e o resumo da anālise de variāncia (Média de 4 repe

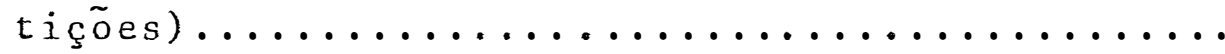

10. Teor percentual de cálcio contido na matéria se ca das diversas partes da planta cultivada em so lução nutritiva, em função dos tratamentos e re sumo da análise de variância (Média de 4 repeti

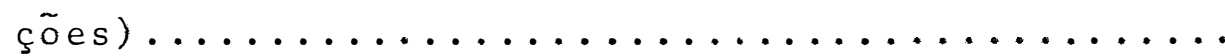

11. Teor percentual de magnésio contido na matéria seca das diversas partes da planta cultivada em solução nutritiva, em função dos tratamentos e re sumo da anālise de variância (Média de 4 repetições)....

12. Teor percentual de enxofre contido na matéria se ca das diversas partes da pianta cultivada em so lução nutritiva, em função dos tratamentos e re sumo da anālise de variância (Média de 4 repeti

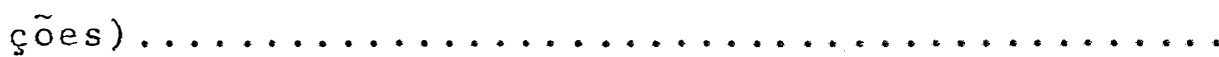

13. Teor em ppm de boro contido na matéria seca das diversas partes da planta cultivada em solução nutritiva, em função dos tratamentos e resumo da anālise de variāncia (Média de 4 repetições).... 
14. Teor em ppm de cobre contido na matéria seca das diversas partes da planta cultivada em solução nutritiva, em função dos tratamentos e resumo da anāilse de variância (Média de 4 repetições)...

15. Teor em ppm de ferro contido na matéria seca das diversas partes da planta cultivada em solução nutritiva, em função dos tratamentos e resumo da anāilse de variância (Média de 4 repetições)....

16. Teor em ppm de manganês contido na matéria seca das diversas partes da planta cultivada em solu ção nutritiva, em função dos tratamentos e resu mo da anālise de variância (Média de 4 repetições)

17. Teor em ppm de zinco contido na matéria seca das diversas partes da planta cultivada em solução nutritiva, em função dos tratamentos e resumo da añàise de variância (Média de 4 repetições)....

18. Teores médios de macronutrientes contidos nas di versas partes da planta em função dos tratamen tos completo e com omissão de nutrientes .......

19. Teores médios de micronutrientes contidos nas di versas partes da planta relativo ao tratamento

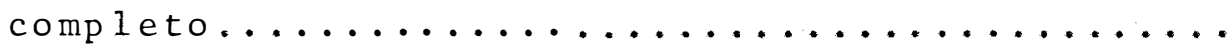

20. Altura das plantas (m) e diâmetro (DAP) do caule $(\mathrm{cm})$, em função das idades (Média de 5 repetições)

21. Equações de regressão, coeficientes de determina ção $\left(R^{2}\right)$, para altura média das plantas (m) e diâmetro (DAP) médio do caule ( $\mathrm{cm}$ ), em função

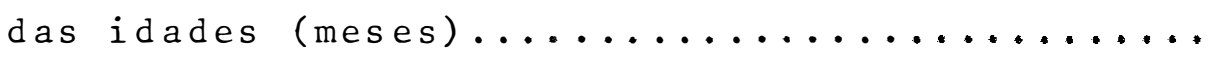


22. Peso da matéria seca (g/planta) acumulada nas dí versas partes e na planta inteira em função das

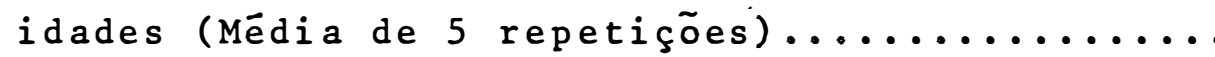

23. Equações de regressão, coeficientes de determina f̧ão $\left(R^{2}\right)$, pontos de mínimo (Pm) das quantidades de matéria seca (g/planta), acumuladas nas dive sas partes e na planta inteira em função das ida

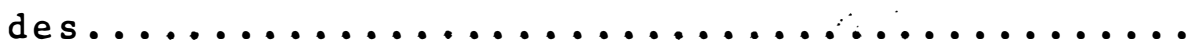

24. Teor percentual de nitrogênio (\%) contido na ma téria seca das diversas partes da planta em fun ção das idades (Média de 5 repetições).........

25. Equações de regressão, coeficientes de determina f̧ão $\left(R^{2}\right)$, pontos de mínimo. (Pm) do teor percen tual de nitrogênio $(\%=y)$ nas diversas partes da planta em função das idades (meses $=x$ )........ 118

26. Quantidades de nitrogênio (g) acumuladas nas di versas partes da planta em função das idades (Mé

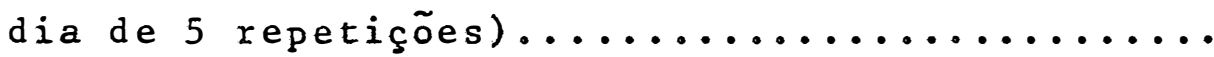

27. Equações de regressão, coeficientes de determina f̧ão $\left(R^{2}\right)$, pontos de mínimo (Pm) das quantidades de nitrogênio ( $g=y)$ acumuladas nas diversas par tes da planta em função das idades (meses $=x$ )....

28. Teor percentual de fósforo (\%) contido na maté ria seca das diversas partes da planta em função das idades (Média de 5 repetiçôes).............

29. Equações de regressão, coeficientes de determina ção $\left(R^{2}\right)$, pontos de máximo (PM) do teor percentual de fósforo $(\%=x)$ nas diversas partes da plan ta em função das idades (meses $=x) \ldots . . . \ldots \ldots$ 
30. Quantidades de fósforo ( $g$ ) acumuladas nas diver sas partes da planta em função das idades (Média

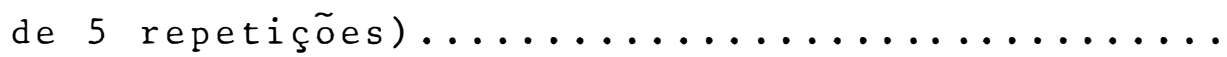

31. Equações de regressão, coeficientes de determina ção $\left(R^{2}\right)$, pontos de mínimo (Pm) da quantidade de fósforo ( $g=y)$ acumuladas nas diversas partes da planta em função das idades (méses $=x) \ldots . . . \ldots$

32. Teor percentual de potássio (\%) contido na maté ria seca das diversas partes da planta em função das idades (Média de 5 repetições)............

33. Equações de regressão, coeficientes de determina ção $\left(R^{2}\right)$, pontos de máximo (PM), pontos de míni mo (Pm) do teor percentual de potássio ( $\%=y)$ nas diversas partes da planta em função das idades

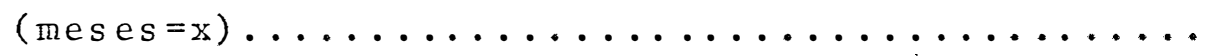

34. Quantidades de potássio ( $g$ ) acumuladas nas diver sas partes da planta em função das idades (Média

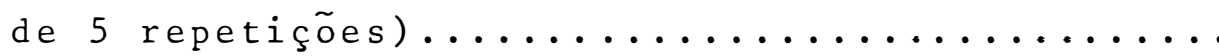

35. Equações de regressão, coeficientes de determina ção $\left(R^{2}\right)$, ponto de máximo (PM) e pontos de míni mo (Pm) das quantidades de potássio ( $g=y$ ) acumu ladas nas diversas partes da planta em funçãodas

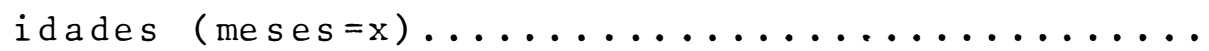

36. Teor percentual de cálcio (\%) contido na matéria seca das diversas partes da'planta, em função das

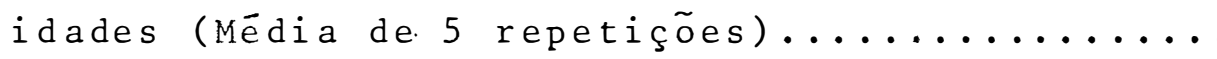


37. Equações de regressão, coeficientes de determina ção $\left(R^{2}\right)$, pontos de mínimo (Pm) do teor perceñ. tual de cálcio $(\%=y)$ nas diversas partes da plan ta. em função das idades (meses $=x) \ldots \ldots \ldots \ldots$

38. Quantidade de cálcio ( $g$ ) acumulada nas diversas partes da planta em função das idades (Média de

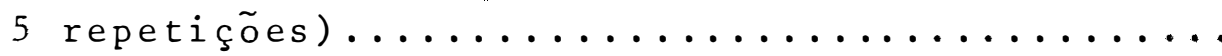

39. Equações de regressão, coeficientes de determina ção $\left(R^{2}\right)$, pontos de mínimo (Pm) das quantidades de cálcio ( $g=y)$ acumuladas nas diversas partes da planta em função das idades (meses=x)....... 134

40. Teor percentual de magnésio (\%) contido na maté ria seca das diversas partes da planta em função das idades (Média de 5 repetições)............

41. Equações de regressão, coeficientes de determina ção $\left(R^{2}\right)$, pontos de mínimo (Pm) do teor perceñ tual de magnésio (\%=y) nas diversas partes da planta em função das idades (meses=x)..........

42. Quantidades de magnésio ( $g$ ) acumuladas nas diver sas partes da planta em função das idades (Média

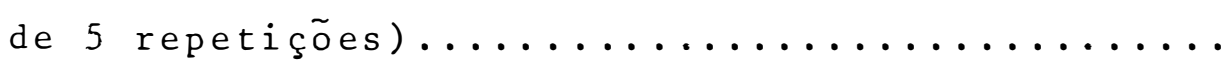

43. Equações de regressão,. coeficientes de determina ção $\left(R^{2}\right)$, pontos de mínimo (Pm) das quantidades de magnésio ( $g=y)$ acumuladas nas diversas partes da planta em função das idades (meses $=x$ )........ 
44. Teor percentual de enxofre (\%) contido na maté ria seca das diversas partes da planta em função das idades (Média de 5 repetições)............ 140

45. Equações de regressão, coeficientes de determina ção $\left(R^{2}\right)$, pontos de mínimo (Pm) do teor perceñ tual de enxofre ( $\%=y)$ nas diversas partes das plantas em função das idades (meses $=x) \ldots . . . .$.

46. Quantidades de enxofre ( $g$ ) acumuladas nas diver sas partes da planta em função das idades (Média

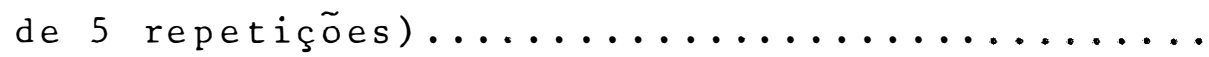

47. Equações de regressão, coeficientes de determina ção $\left(R^{2}\right)$, pontos de mínimo (Pm) das quantidades de enxofre ( $g=y)$ acumuladas nas diversas partes da planta em função das idades (meses=x).......

48. Teor em ppm de boro contido na matéria seca das diversas partes da planta em função das idades

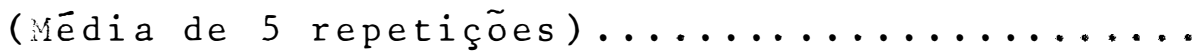

49. Equações de regressão, coeficientes de determina ção $\left(R^{2}\right)$, pontos de mínimo (Pm) do teor em ppm de boro (ppm=y) nas diversas partes da planta, em função das idades (meses=x)............... 145

50. Quantidades de boro ( $\mathrm{mg}$ ) acumuladas nas diversas partes da planta em função das idades (Média de

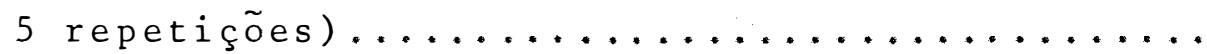

51. Equações de regressão, coeficientes de determina ção $\left(R^{2}\right)$, pontos de mínimo (Pm) das quantidades de boro (mg=y) acumuladas nas diversas partes da planta em função das idades (meses=x) .......... 147 
52. Teor em ppm de cobre contido na matéria seca das diversas partes da planta em função dás idades

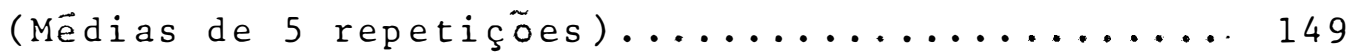

53. Equações de regressão, coeficientes de determina çäo $\left(R^{2}\right)$, pontos de mínimo (Pm) do teor em ppm de cobre (ppm=y) nas diversas partes da planta, em função das idades $($ meses $=x) \ldots \ldots \ldots \ldots \ldots$

54. Quantidades de cobre ( $\mathrm{mg}$ ) acumuladas nas diver sas partes da planta em função das idades (Média

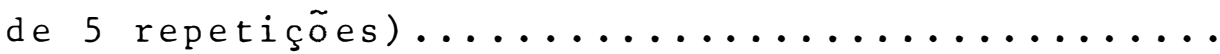

55. Equações de regressão, coeficientes de determina ção $\left(R^{2}\right)$, pontos de mínimo (Pm) das quantidades de cobre (mg=y) acumuladas nas diversas partes da planta em função das idades (meses=x).......

56. Teor em ppm de ferro contido na matéria seca das diversas partes da planta em função das idades

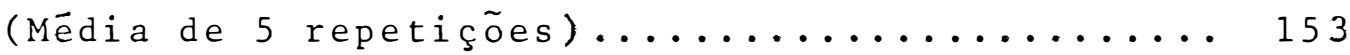

57. Equações de regressão, coeficientes de determina ção $\left(R^{2}\right)$, pontos de mínimo (Pm) do teor em ppm de ferro (ppm=y) nas diversas partes da planta em função das idades $($ meses $=x) \ldots \ldots \ldots \ldots \ldots$

58. Quantidades de ferro (mg) acumuladas nas diver sas partes da planta em função das idades (Média

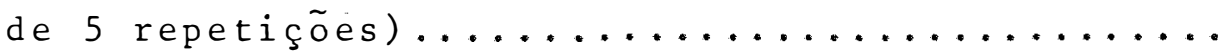

59. Equações de regressão, coeficientes de determina ção $\left(R^{2}\right)$, pontos de mínimo (Pm) das quantidádes deferro (mg=y) acumuladas nas diversas partes da planta em função das idades (meses=x)....... 
60. Teor em ppm de manganês contido na matéria seca das diversas partes da planta em função das idą

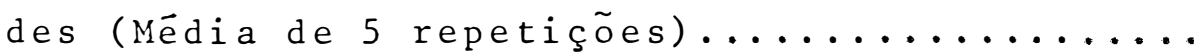

61. Quantidades de manganês (mg) acumuladas nas di versas partes da planta em função das idades (Mé

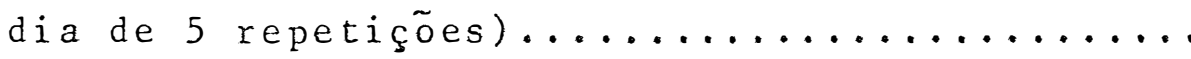

62. Equações de regressão, coeficientes de determina ção $\left(R^{2}\right)$, pontos de mínimo (Pm) das quantidades de manganês (mg=y) acumuladas nas diversas par tes da planta em função das idades (meses=x)...

63. Teor em ppm de zinco contido na matéria seca das diversas partes da planta em função das ida

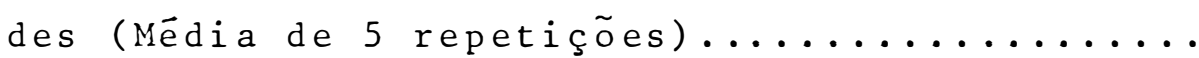

64. Equações de regressão, coeficientes de determi nação $\left(R^{2}\right)$, pontos de mínimo (Pm) do teor em ppm de zinco (ppm=y) contidos nas diversas par tes da planta em função das idades (meses=x)...

65. Quantidades de zinco ( $\mathrm{mg}$ ) acumuladas nas diver sas partes da planta em função das idades (Média

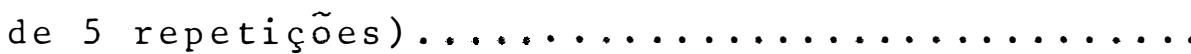

66. Equações de regressão, coeficientes de determi nação $\left(R^{2}\right)$, pontos de mínimo (Pm) das quantidą des de zinco (mg=y) acumuladas nas diversas par tes da planta em função das idades (meses=x)...

67. Concentração dos macro e micronutrientes nas di versas partes da planta de Córáia goeldiana em

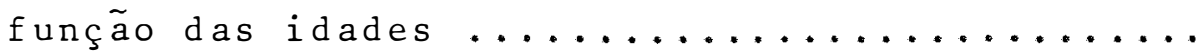


68. Dados comparativos de nutrientes em folhas e/ou acículas de diversas espécies florestais e

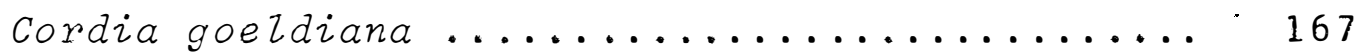

69. Distribuição e quantidades de nutrientes acumu ladas pelas diversas partes da planta de Cordia

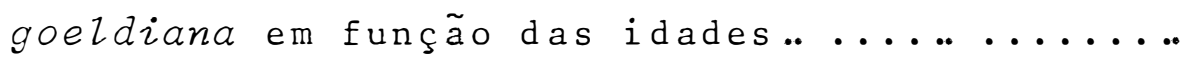

70. Dados comparativos das quantidades de nutrien tes acumuladas pelas diversas espécies em fun

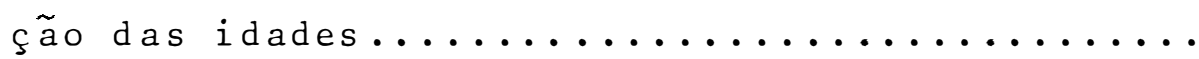

71. Quantidades de nutrientes e percentagem de ex portação pelo caule de Cordia goeldiana aos 96

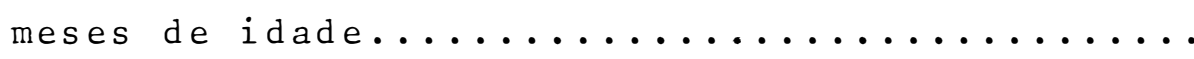


xvii.

SINTOMATOLOGIA DAS CARENCIAS DE NACRONUTRIENTES EM CASA DE VEGETAÇÃO FECRUTAMENTO DE NUTRIENTES PELO FREIJO (Cordia goeldiana, Huber) AOS 2, 3, 4 e 8 ANOS DE IDADE IMPLANTADO EN LATOSSOLO AMARELO ; DISTROFICO, BELTERRA, PARA

Autor: DILSON AUGUSTO CAPUCHO FRAZÃO

Orientador: Prof. Dr. RONALDO IVAN SILVEIRA

RES UMO

No presente trabalho, estudou-se alguns aspectos da nutrição mineral do "freijó" (Cordia goeldiana, Huber) através de dois experimentos, sendo um em casa de vegetação e outro em campo, com os seguintes objetivos: obtenção de sin tomas de deficiência de nitrogênio, fósforo, potássio, cálcio, magnésio e enxofre; avaliação do desenvolvimentóinicial das plantas pela análise da produção de matéria seca; determinar a concentração dos macronutrientes nas folhas superio res, folhas inferiores, ramos, caule e raízesdas plantas cultivadas na ausência desses nutrientes; verificar o efeito da omissão do nutriente no aumento ou diminuição da concentração do mesmo ou dos outros nas diversas partes da planta; verifi car a distribuição da matéria seca total nas plantas com 24, 36, 48 e 96 meses de idade; determinar a concentração dos macronutrientes nas diferentes partes da planta em função da idade; determinar o acümulo dos macronutrientes nas plantas em função de idade' e verificar a exportação dos macró e micro 
xvi i

nutrientes pelo caule das plantas com 96 meses de idade.

No experimento de casa de vegetação, plantas de freijo foram cultivadas em substrato de sílica e irrigadas com soluções nutritivas, sendo os tratamentos: completo, omissão de nitrogênio, omissão de fósforo, omissão de potássio, omis são de cálcio, omissão de magnésio e omissão de enxofre. Acom panhou-se o desenvolvimento dos sintomas e uma vez evidencia dos, realizou-se a coleta das plantas e a separação em folhas superiores, folhas inferiores, ramos, caule e raiz e analisou se as diversas partes para os nutrientes.

No experimento de campo foram coletadas plantas de freijó com 24, 36, 48 e 96 meses de idade em populações instaladas em solo do tipo Latossolo Amarelo distrófico textura muito argilosa no Campo Experimental de Belterra, município de Santarém, Estado do Pará. Após a coleta das plantas, foram retiradas amostras de folhas, ramos e caule (base, meio e ponta) para análise dos nutrientes.

Através da anālise estatística e interpretação dos resultados de acordo com a metodologia empregada obteve-se as seguintes conclusões:

- A produção de matéria seca total das plantas foi afetada em todos os tratamentos com omissão de nutrientes, obedecendo a seguinte ordem decrescente: nitrogênio, fós foro, cálcio, potássio, enxofre e magnésio.

- Os sintomas visuais de deficiência de nitro- 
xix.

gênio, fósforo, potássio, cālcio, magnésio e enxofre apresentaram-se de uma maneira geral bem definidos e de fácil caracterização.

- As plantas apresentaram sintomas de carência quando os níveis dos elementos mostraram valores iguais e abaixo de: Nas folhas superiores - $1,03 \%$ de $N ; 0,08 \%$ de $P ; 0,33 \%$ de $K ; 0,95 \%$ de $\mathrm{Ca} ; 0,34 \%$ de $\mathrm{Mg}$ e $0,09 \%$ de $\mathrm{S}$. Nas folhas inferiores - $0,88 \%$ de $N ; 0,04 \%$ de $P ; 0,07 \%$ de $K ; 1,66 \%$ de $C a ; 0,26 \%$ de $\mathrm{Mg}$ e $0,10 \%$ de S. Nos ramos $-0,66 \%$ de $N ; 0,13 \%$ de $P ; 0,36 \%$ de $K ; 0,42 \%$ de $\mathrm{Ca} ; 0,12 \%$ de $\mathrm{Mg}$ e $0,06 \%$ de $\mathrm{S}$. No caule - 0,53\% de $\mathrm{N} ; 0,07 \%$ de $P ; 0,40 \%$ de $K ; 0,32 \%$ de $\mathrm{Ca} ; 0,09 \%$ de $\mathrm{Mg}$ e $0,04 \%$ de $\mathrm{S}$. Nas raízes $-0,94 \%$ de $N ; 0,10 \%$ de $P ; 0,32 \%$ de $K ; 0,43 \%$ de $C a ; 0,25 \%$ de $\mathrm{Mg}$ e $0,08 \%$ de $\mathrm{S}$.

- Os efeitos da omissão de um nutriente aumentando ou diminuindo a concentração do mesmo e dos outros nos órgãos foram os seguintes:

\begin{tabular}{|c|c|c|c|c|c|c|}
\hline $\begin{array}{l}\text { Nutr. } \\
\text { Def. }\end{array}$ & & Raízes & Caule & Ramos & $\begin{array}{l}\text { Folhas } \\
\text { inferiores }\end{array}$ & $\begin{array}{l}\text { Folhas } \\
\text { superiores }\end{array}$ \\
\hline $\mathrm{N}$ & $\begin{array}{l}\text { aumenta } \\
\text { diminui }\end{array}$ & $\mathrm{N}, \mathrm{S}$ & $\begin{array}{c}\mathrm{P}, \mathrm{Fe} \\
\mathrm{N}, \mathrm{Mg}, \mathrm{S}\end{array}$ & $\mathrm{N}, \mathrm{Ca}$ & $\begin{array}{l}\mathrm{P}, \mathrm{K}, \mathrm{B}, \mathrm{Mn} \\
\mathrm{N}, \mathrm{Ca}\end{array}$ & $\begin{array}{l}\mathrm{P}, \mathrm{B} \\
\mathrm{N}, \mathrm{Ca}\end{array}$ \\
\hline $\mathrm{P}$ & $\begin{array}{l}\text { aumenta } \\
\text { diminui }\end{array}$ & $\bar{p}$ & $\bar{p}$ & $\underset{P, N}{K}$ & $\begin{array}{c}R \\
P, N\end{array}$ & $\begin{array}{c}\mathrm{K} \\
\mathrm{P}, \mathrm{N}\end{array}$ \\
\hline $\mathrm{K}$ & $\begin{array}{l}\text { aumenta } \\
\text { diminui }\end{array}$ & $\underset{\mathrm{K}}{\mathrm{S}, \mathrm{Mn}}$ & $\mathrm{K}_{, \mathrm{B}}^{-}$ & $\mathrm{Kg}$ & $\begin{array}{l}\mathrm{P}, \mathrm{Mg}, \mathrm{Mm} \\
\mathrm{K}, \mathrm{N}\end{array}$ & $\underset{\mathrm{K}}{\mathrm{P}, \mathrm{Ca}, \mathrm{Mg}, \mathrm{B}}$ \\
\hline $\mathrm{Ca}$ & $\begin{array}{l}\text { aumenta } \\
\text { diminui }\end{array}$ & $\begin{array}{c}\mathrm{K}, \mathrm{S}, \mathrm{Fe}, \mathrm{Mn} \\
\mathrm{Ca}\end{array}$ & $\begin{array}{c}\mathrm{K}, \mathrm{Fe} \\
\mathrm{Ca}\end{array}$ & $\begin{array}{l}\mathrm{K}, \mathrm{Fe}, \mathrm{Mn} \\
\mathrm{Ca}\end{array}$ & $\begin{array}{l}\mathrm{P}, \mathrm{Mg}, \mathrm{K}, \mathrm{S}, \mathrm{Fe}, \mathrm{Mm} \\
\mathrm{Ca}, \mathrm{N}, \mathrm{B}\end{array}$ & $\underset{\mathrm{Ca}}{\mathrm{P}, \mathrm{Mg}, \mathrm{K}, \mathrm{S}, \mathrm{B}, \mathrm{Fe}, \mathrm{M} \text { 血 }}$ \\
\hline $\mathrm{Mg}$ & $\begin{array}{l}\text { aumenta } \\
\text { diminui }\end{array}$ & $\begin{array}{c}\mathrm{K}, \mathrm{S}, \mathrm{Mn} \\
\mathrm{Mg}\end{array}$ & $\begin{array}{l}\mathrm{K}, \mathrm{Mnn} \\
\mathrm{Mg}, \mathrm{B}\end{array}$ & $\stackrel{\mathrm{K}}{\mathrm{Mg}, \mathrm{Ca}, \mathrm{B}}$ & $\begin{array}{c}\mathrm{P}, \mathrm{K}, \mathrm{M} \text { m } \\
\mathrm{Mg}, \mathrm{B}\end{array}$ & $\begin{array}{c}\mathrm{P}, \mathrm{K} \underset{\mathrm{Mg}}{\mathrm{M}} \\
\text { Mg }\end{array}$ \\
\hline$S$ & $\begin{array}{l}\text { aumenta } \\
\text { diminui }\end{array}$ & $\begin{array}{l}\mathrm{K} \\
\mathrm{S}\end{array}$ & $\begin{array}{c}\mathrm{K} \\
\mathrm{S}, \mathrm{B}, \mathrm{Cu}\end{array}$ & $\begin{array}{c}\mathrm{K} \\
\mathrm{S}, \mathrm{B}\end{array}$ & $\begin{array}{c}\mathrm{K} \\
\mathrm{S}, \mathrm{B}, \mathrm{Cu}\end{array}$ & $\mathrm{S}, \mathrm{N}_{\mathbf{N}, \mathrm{Cu}}^{\mathrm{K}}$ \\
\hline
\end{tabular}


- A Cordia goeldiana é uma espécie exigente em nutrientes.

- A distribuição da matéria seca total, nas quatro idades estudadas $(24,36,48$ e 96 meses), obedece a seguinte ordem decrescente: caule (base, meio e ponta) ramos e folhas.

- Nas plantas as maiores concentrações de nutrientes ocorrem nas folhas, exceto para zinco que mostra teo res mais elevados nos ramos.

- A concentração dos nutrientes nas partes da planta difere de modo a evidenciar a translocação dos mesmos no interior do vegetal.

- A ordem relativa das concentrações de nutrientes decresce de acordo com a sequiência $\mathrm{N}, \mathrm{K}, \mathrm{Ca}, \mathrm{Mg}, \mathrm{S}, \mathrm{P}$, $\mathrm{Fe}, \mathrm{B}, \mathrm{Mn}, \mathrm{Cu}, \mathrm{Zn}$ nas folhas; $\mathrm{N}, \mathrm{Ca}, \mathrm{K}, \mathrm{Mg}, \mathrm{P}, \mathrm{S}, \mathrm{Fe}, \mathrm{Zn}, \mathrm{B}$, $\mathrm{Cu}, \mathrm{Mn}$ nos ramos; $\mathrm{N}, \mathrm{K}, \mathrm{Ca}, \mathrm{Mg}, \mathrm{P}, \mathrm{S}, \mathrm{Fe}, \mathrm{Mn}, \mathrm{Zn}, \mathrm{B}, \mathrm{Cu}$ na ponta e meio do caule e $\mathrm{N}, \mathrm{Ca}, \mathrm{K}, \mathrm{Mg}, \mathrm{S}, \mathrm{P}, \mathrm{Fe}, \mathrm{Mn}, \mathrm{Zn}, \mathrm{Cu}$ na base do caule.

- A quantidade (gramas) dos nutrientes analisa dos por quilograma de matéria seca decresce em relação à idade das plantas. Esta relação é de $31,7 \mathrm{~g}$ de nutrientes aos 24 meses de idade e $19,4 \mathrm{~g}$ aos 96 meses de idade.

- Considerando a idade de maior acúmulo (96 meses) o nitrogênio foi o macronutriente mais extraído seguido em ordem decrescente do cálcio, potássio, magnésio, enxofre e fósforo. Quanto aos micronutrientes, o elemento extraído em maior quantidade foi o ferro seguido do zinco, manganês, cobre e boro. 
$x \times i$.

- Aos 96 meses de idade o magnésio é o nutrien te que apresenta maior porcentagem de exportação pelo caule, vindo a seguir em ordem decrescente manganês, cálcio, potássio, ferro, cobre, zinco, fósforo, nitrogênio, boro e enxofre. 
SINTOMATOLOGY OF MACRONUTRIENTS DEFICIENCY ON GREENHOUSE . AND NUTRIENT ABSORPTION BY FREIJO (Cordia goendiana, Huber) ON 2, 3, 4 AND 8 YEARS OF AGE ESTABLISHED ON DISTROPHIC YELLOW LATOSOL, BELTERRA, PARA

\author{
Author: DILSON AUGUSTO CAPUCHO FRAZÃO \\ Adviser: Prof. Dr. RONALDO IVAN SILVEIRA
}

\title{
S UMMARY
}

Some aspects of mineral nutrition of "freijo" (Cordia goeldiana, Huber) were studied in two experiments, one in greenhouse and the other on the field, with the following objectives: to find deficiency symptoms of nitrogen, phosphorus, potassium, calcium, magnesium and sulphur; to evaluate the plants initial development by means of dry matter production analysis; to determine macronutrients concentration on upper and lower leaves, branches, stem and roots of plants grown in the absence of these nutrients; to observe the effect of nutrient omission on the concentration increase or decrease of the same or the others on the various plant parts; to observe the total dry matter distribution on plants with $24,36,48$ and 96 months of age; to determine the macronutrients concentration on different plant parts according to age; to determine the macro and micronutrients accumulation on plants according to age and to examine the macro and micronutrients exportation by the stem of 96-months- old plants. 
On the greenhouse experiment freijo plants were cultivated in pots containing pure quartz and irrigated with nutrient solution, with the following treatments: full solution, omission of nitrogen, omission of phosphorus, omission of potassium, omission of calcium, omission of magnesium and omission of sulphur. The development of deficiency symptoms were followed, and once identified, the collection of plants and posterior separation in upper leaves, lower leaves, branches, stem and root were made, the various plant parts were analysèd.

On the field experiment, $24,36,48$ and

months old freijo plants were collected from populations settled on very clayey distrophic Yellow Latosol at Belterra Research Station, county of Santarém, State of Pará. After the plant collection, samples of leaves, branches and stem (base, center and top) were sampled for nutrient analysis.

Though statistical analysis and interpretation. of the results, according to the used methodology, the following. conclusions were made:

- The total dry matter production of plants was affected in all treatments with nutrient omission according to the following decreasing order: nitrogen, phosphorus, calcium, potassium, sulphur and magnesium。

- The visual deficiency symptoms of 'nitrogen, phosphorus, potassium, calcium, magnesium and sulphur were generally well defined and easily characterized. 
xxiv.

- The plants showed deficiency symptoms

when

the nutrient levels had values equal and lower than: Upper leaves $1.03 \%$ of $\mathrm{N} ; 0.08 \%$ of $\mathrm{P} ; 0.33 \%$ of $\mathrm{K} ; 0.95 \%$ of $\mathrm{Ca} ; 0.34 \%$ of $\mathrm{Mg}$ and $0.09 \%$ of $\mathrm{S}$. Lower leaves - $0.88 \%$ of $\mathrm{N} ; 0.04 \%$ of $\mathrm{P} ; 0.07 \%$ of $\mathrm{K}$; $1.66 \%$ of $\mathrm{Ca} ; 0.26 \%$ of $\mathrm{Mg}$ and $0.10 \%$ of $\mathrm{S}$. Branches $-0.66 \%$ of $\mathrm{N} ; 0.13 \%$ of $\mathrm{P} ; 0.36 \%$ of $\mathrm{K} ; 0.42 \%$ of $\mathrm{Ca} ; 0.12 \%$ of $\mathrm{Mg}$ and $0.06 \%$ of S. Stem $-0.53 \%$ of $\mathrm{N} ; 0.07 \%$ of $\mathrm{P} ; 0.40 \%$ of $\mathrm{K} ; 0.32 \%$ of $\mathrm{Ca} ; 0.09 \%$ of $\mathrm{Mg}$ and $0.04 \%$ of $\mathrm{S}$. Roots $-0.94 \%$ of $\mathrm{N} ; 0.10 \%$ of $\mathrm{P} ; 0.32 \%$ of $\mathrm{K} ; 0.43 \%$ of $\mathrm{Ca} ; 0.25 \%$ of $\mathrm{Mg}$ and $0.08 \%$ of $\mathrm{S}$. - The omission effects of a nutrient increasing or decreasing its own or the other concentration on the organs were as follows:

\begin{tabular}{|c|c|c|c|c|c|c|}
\hline $\begin{array}{l}\text { Nutr. } \\
\text { Def. }\end{array}$ & & Roots & Stem & Branches & $\begin{array}{l}\text { Lower } \\
\text { leaves }\end{array}$ & $\begin{array}{l}\text { Upper } \\
\text { leaves. }\end{array}$ \\
\hline $\mathrm{N}$ & $\begin{array}{l}\text { increases } \\
\text { decreases }\end{array}$ & $\overline{\mathrm{N}, \mathrm{S}}$ & $\begin{array}{c}\mathrm{P}, \mathrm{Fe} \\
\mathrm{N}, \mathrm{Mg}, \mathrm{S}\end{array}$ & $\mathrm{N}, \mathrm{Ca}$ & $\begin{array}{l}\mathrm{P}, \mathrm{K}, \mathrm{B}, \mathrm{Mn} \\
\mathrm{N}, \mathrm{Ca}\end{array}$ & $\begin{array}{l}\mathrm{P}, \mathrm{B} \\
\mathrm{N}, \mathrm{Ca}\end{array}$ \\
\hline$P$ & $\begin{array}{l}\text { increases } \\
\text { decreases }\end{array}$ & $\bar{P}$ & $\overline{\mathrm{P}}$ & $\stackrel{\mathrm{K}}{\mathrm{P}, \mathrm{N}}$ & $\stackrel{K}{P, N}$ & $\begin{array}{c}\mathrm{K} \\
\mathrm{P}, \mathrm{N}\end{array}$ \\
\hline K & $\begin{array}{l}\text { increases } \\
\text { decreases }\end{array}$ & $\begin{array}{l}\mathrm{S}, \mathrm{Mn} \\
\mathrm{K}\end{array}$ & $\mathrm{K}, \mathrm{B}$ & $\begin{array}{r}\mathrm{Mg} \\
\mathrm{K}, \mathrm{B}\end{array}$ & $\begin{array}{l}\mathrm{P}, \mathrm{Mg}, \mathrm{Mn} \\
\mathrm{K}, \mathrm{N}\end{array}$ & $\underset{\mathrm{K}}{\mathrm{P}, \mathrm{Ca}, \mathrm{Mg} ; \mathrm{B}}$ \\
\hline $\mathrm{Ca}$ & $\begin{array}{l}\text { increases } \\
\text { decreases }\end{array}$ & $\begin{array}{c}\mathrm{K}, \mathrm{S}, \mathrm{Fe}, \mathrm{Mn} \\
\mathrm{Ca}\end{array}$ & $\begin{array}{c}\mathrm{K}, \mathrm{Fe} \\
\mathrm{Ca}\end{array}$ & $\begin{array}{l}\mathrm{K}, \mathrm{Fe}, \mathrm{Mn} \\
\mathrm{Ca}\end{array}$ & $\begin{array}{c}\mathrm{P}, \mathrm{Mg}, \mathrm{K}, \mathrm{S}, \mathrm{Fe}, \mathrm{Mn} \\
\mathrm{Ca}, \mathrm{B}, \mathrm{N}\end{array}$ & $\underset{\mathrm{Ca}}{\mathrm{P}, \mathrm{Mg}, \mathrm{K}, \mathrm{S}, \mathrm{B}, \mathrm{Fe}, \mathrm{M}}$ \\
\hline $\mathrm{Mg}$ & $\begin{array}{l}\text { increases } \\
\text { decreases }\end{array}$ & $\begin{array}{c}\mathrm{K}, \mathrm{S}, \mathrm{Nm} \\
\mathrm{Mg}\end{array}$ & $\begin{array}{l}\mathrm{K}, \mathrm{Mn} \\
\mathrm{Mg}, \mathrm{B}\end{array}$ & $\underset{\mathrm{Mg}, \mathrm{Ca}, \mathrm{B}}{\mathrm{K}}$ & $\begin{array}{c}\mathrm{P}, \mathrm{K}, \mathrm{Mn} \\
\mathrm{Mg}, \mathrm{B}\end{array}$ & $\begin{array}{c}\mathrm{P}, \mathrm{K}, \mathrm{Mm} \\
\mathrm{Mg}\end{array}$ \\
\hline$S$ & $\begin{array}{l}\text { increases } \\
\text { decreases }\end{array}$ & $\begin{array}{l}\mathrm{K} \\
\mathrm{S}\end{array}$ & $\begin{array}{c}\mathrm{K} \\
\mathrm{S}, \mathrm{B}, \mathrm{Cu}\end{array}$ & $\begin{array}{c}K \\
S, B\end{array}$ & $\mathrm{~K}, \mathrm{~B}, \mathrm{Cu}$ & $\begin{array}{l}\mathrm{K} \\
\mathrm{S}, \mathrm{N}, \mathrm{Cu}\end{array}$ \\
\hline
\end{tabular}

- Cordia goeldiana is a species demanding of nutrients. 
- The total dry matter distribution,in the four studied ages ( $24,36,48$ and 96 monthers of age) obey the following decreasing order: stem (base, center and top), branches and leaves.

- The highest nutrient concentrations ocurred on leaves, except for zinc that showed highes levels on the branches.

- The nutrient concentration on the plant parts differs so as to make evident their flow inside. the plant.

- The relative order of the nutrient concentration decreases according to the following sequence: $N, k$, $\mathrm{Ca}, \mathrm{Mg}, \mathrm{S}, \mathrm{P}, \mathrm{Fe}, \mathrm{B}, \mathrm{Mn}, \mathrm{Cu}, \mathrm{Zn}$ on the leaves; $\mathrm{N}, \mathrm{Ca}, \mathrm{K}, \mathrm{Mg}$, $\mathrm{P}, \mathrm{S}, \mathrm{Fe}, \mathrm{Zn}, \mathrm{B}, \mathrm{Cu}, \mathrm{Mn}$ on the branches; $\mathrm{N}, \mathrm{K}, \mathrm{Ca}, \mathrm{Mg}, \mathrm{P}, \mathrm{S}$, $\mathrm{Fe}, \mathrm{Mn}, \mathrm{Zn}, \mathrm{B}, \mathrm{Cu}$ on the top and center of the stem and $\mathrm{N}$, $\mathrm{Ca}, \mathrm{K}, \mathrm{Mg}, \mathrm{S}, \mathrm{P}, \mathrm{Fe}, \mathrm{Mn}, \mathrm{Zn}, \mathrm{Cu}$ on the stem base.

- The amount (grams) of analized nutrients per kilogram of dry matter decreases according to plant age. This relation is of $31,7 \mathrm{~g}$ of nutrients at 24 months of age and $19,4 \mathrm{~g}$ at 96 months of age.

- Considering the age of higher accumulation (96 months nitrogen was the most extracted macronutrient followed in decreasing order by calcium, potassium, magnesium, sulphur and phosphorus. For the micronutrients the most extracted nutrient was the iron followed by zinc, manganese, copper and boron. 
- At 96 monthes of age magnesium is the nutrient with the greatest exportation percentage by the stem, followed in a decreasing order, by manganese, calcium, potassium, iron, copper, zinc, phosphorus, nitrogen, borum and sulphur. 


\section{INTRODUÇÃO}

Fazendo-se uma anälise da contribuição do setor florestal no desenvolvimento da economia brasileira, pode -se concluir facilmente que ela tem sido da maior importância, uma vez que a participação da madeira e de seus produtos industrializados no total das exportaçoes duplicou em menos de uma década, gerando uma receita em 1983, em torno de 900 milhões de dólares, com a exportação de produtos florestais (EMPRESA BRASILEIRA DE PESQUISA AGROPECUARIA/INSTITUTO BRASILEIRO DE DESENVOLVIMENTO FLORESTAL, 1984a).

Em face do crescimento acelerado das exportações, bem como do parque industrial brasileiro utilizando matéria-prima de origem florestal, fica evidenciado a necessidade de se examinar e aprimorar a metodologia de trabalho que vem sen do empregada na ärea da Silvicultura Nacional, considerando que possuimos um dos maiores programas de reflorestamento do mundo e que precisa ser ampliado e conduzido de forma que o 
aumento da produtividade florestal por unidade de área seja progressivo.

Ao lado das preocupações, de maiores cuidados com o material genético a ser utilizado, preparo de solo, manejo, exploração e proteção florestal observa-se atualmente uma carência muito grande na ärea de pesquisa em nutrição e fertilização florestal. Entretanto, um dos problemas mais sé rios, é a falta de informações básicas sobre a nutrição das espécies encontradas nas diferentes regiões ecológicas do país, uma vez que esses dados são indispensáveis para o estabelecimento de hipótese de trabalho, visando também a interpretações de resultados de difícil explicação.

Pelo exposto, considerando que a grande totalidade das espécies florestais encontram-se em solos de baixa fertilidade, bem como os problemas de ordem nutricional que as espécies vêm apresentando, hà necessidade de um maior número de trabalhos de pesquisa em nutriçãomineral, pois assim procedendo-se estaremos adquirindo conhecimentos necessários para o uso racional de fertilizantes, aumentando conseqüentemente a produtividade das florestas de maneira a atender as necessidades dos mercados interno e externo.

Na atual conjuntura, a Amazônia Brasileira apa rece como uma grande opção como fonte fornecedora de madeira e produtos florestais tropicais com seus 280 milhões de hecta res e reservas madeireiras estimadas em 50 bilhós de metros cūbicos, sendo 16 bilhões de metros cūbicos comerciāveis 
em virtude dos países tradicionalmente abastecedores do mercado mundial estarem diminuindo a produção, bem como em função da sua potencialidade e diversidade de espécies de grande valor comercial (EMPRESA BRASILEIRA DE PESQUISA AGROPECUARIA/ instituto BRASileiro DE DESENVOLVImento Florestal, 1984b). Po rém, sua exploração racional terá que ser apoiada na pesquisa, uma vez que os dados existentes são insuficientes para o estabelecimento de sistemas de manejo adequados à região objetivando uma produção sustentada, técnica e economicamente viāvel.

Entre as diversas espécies madeireiras de grande valor comercial da região amazônica, o "freijō" (Cordia goeldiana, Huber) tem merecido destaque especial em vista das suas características silviculturais e alcançado preços altamente competitivos nos mercados interno e externo, como espécie apropriada para a indústria de móveis, laminados, painéis, lambris e construções navais e aeronáuticas.

Pelo exposto; considerando a carência de trabalhos experimentais referentes à nutrição mineral do freijó e a necessidade fundamental de estudos básicos para o es tabelecimento de um programa de pesquisa nesta área, desenvol veu-se dois experimentos, em casa de vegetação e no campo, com os seguintes objetivos:

- obtenção de sintomas de deficiências minerais de nitrogênio, fósforo, potássio, cálcio, magnésio e enxofre; 
- avaliação do desenvolvimento inicial das plantas através da anāilise da produção de matéria seca;

- determinar a concentração dos macronutrientes nas folhas su periores, folhas inferiores, ramos, caule e raízes das plantas cultivadas na ausência desses nutrientes;

- verificar o efeito da omissão do nutriente no aumento ou di minuição da concentração do mesmo e dos outros nas diversas partes da planta;

- verificar a distribuição da matéria seca total nas plantas com $24,36,48$ e 96 meses de idade;

- determinar a concentração dos macro e micronutrientes nas diferentes partes da planta em função da idade;

- determinar o acúmulo dos macro e micronutrientes nas plantas, em função da idade;

- verificar a exportação dos macro e micronutrientes pelo cau le de plantas com 96 meses de idade. 


\section{REVISÃo DE LITERATURA}

\subsection{Considerações sobre a espécie}

Cordia goeldiana, Huber (freijó) è uma das principais espécies madereiras da regiắo amazônica, tendo sido citada por YARED et alii (1980) e CARPANEZZI e YARED (1981) como de grande potencial para plantios comerciais. Na América as espécies mais importantes do genero Cordia produtoras de madeira comercial são Cordia tricho toma (Vel1.) Arrab. principalmente na região Sul do Brasil e regiões fronteiras da Argentina e Paraguai Cordia alliodora (R. \& P.) Oken explorada nas äreas tropicais a noroeste da Ama zônia Brasileira e principalmente na América Central e a Cordia goeldiana, Huber na Amazônia Brasileira.

Segundo RODRIGUES (1982), a Cordia goeldiana é uma das espécies do gênero que alcança porte arbóreo com cerca de 30 m. de altura, porém CARPANEZZI e KANASHIRO (1982) informam que em cerca de 50 árvores selecionadas para coleta de semen- 
tes na Floresta Nacional do Tapajós, foram encontradas plantas com alturas totais de 40 a $45 \mathrm{~m}$ e diâmetros (DAP) de 80 a $100 \mathrm{~cm}$ e que na maioria das vezes a relação entre maiores alturas e diâmetros maiores não ocorre junto numa mesma árvore.

Considerando o valor de sua madeira, o frei jó vem sendo hã vários anos uma das espécies mais visadas pela exploração seletiva, entretanto recentemente, trabalhos de pesquisa resultaram na sua indicação como uma das mais impor tantes espécies para regeneração artificial, face as suas características silviculturais.

Por outro lado, de acordo com CARPANEZZI et alii (1983), BRIENZA JUNIOR (1982a) e BRIENZA JUNIOR (1982c) o freijó pode adaptar-se a diversos métodos silviculturais, como "taungya"*, plantios em vegetação matricial (florestas ex ploradas e capoeiras) e, em caráter comprobatório, em plantios homogêneos a pleno sol, podendo servir a produtores de diferentes níveis econômicos, como pequenos proprietários e empresas reflorestadoras, as quais recentemente passaram a cluir a espécie em seus programas. Outrofato que deve ser

* "taungya" - técnica que busca reduzir o custode formação de povoamentos florestais de rendimentos, mediante a associação temporária de cultivos de ciclo curto, durante os dois ou três anos iniciais do período de estabelecimentodos povoamentos (KING, 1968). 
considerado segundo BRIENZA JUNIOR (1982b) è o grande potencial da espécie para combinações silvoagrícola e silvopastó ril, onde a pesquisa já está testando estes sistemas na Amazô nia. No caso de combinações silvoagrícolas com algumas espécies perenes, jā existe um exemplo pioneiro no município de Tomé-Açu, Estado Parā, onde agricultores de origem japonesa utilizaram o freijó para sombreamento definitivo de cacau (Theobroma cacao, L.) que substituiu pimentais (Piper nigrum L.) decadentes atacados pelo fungo Fusarium solani var.piperi. Outros agricultores estabeleceram consorciaçōes em pequena es cala de freijó com café (Cofbea spp.), com guaranà (Paullinia cupana var. sorbilis (Mart.) Ducke) e com cupuaçu (Theobroma grandiflorum shum).

Não hà informação quanto a longevidade do frei jó, uma vez que ainda é especulativa a estimativa de uma ida de de corte final em face de todos os plantios existentes serem jovens. Como indicação CARPANEZZI et alii (1983) mencionam que as medições de povoamentos de 6,5 anos em Belterra e 5,5 a 6,5 anos em Tomé-Açu, Estado do Pará, revelam incrementos médios anuais de diâmetro de 2 a $2,5 \mathrm{~cm}$. Portanto, a continuar esses resultados espera-se que as ärvores atinjam dimensões para serraria numa rotação de aproximadamente 25-30 anos.

Quanto as características silviculturais BRIEN ZA JUNIOR ( $1982 \mathrm{~b}$ ) relata que a espécie possui crescimento ini 
cial rápido, árvores de boa forma, fuste reto, boa dominância apical e desrama natural.

A Cordia goeldiana é uma espécie que pertence a família Borraginaceae, cujo gênero possui cerca de 250 espécies tropicais e subtropicais. E conhecida vulgar e comercialmente como: "freijo", "freijo-cinza", "frei-Jorge", "frejo", "freijó verdadeiro" no Brasil (PIO CORREA, 1952; BRA SIL/SUDAM, 1979 ; SILVA, 1977 e RIZZINI, 1971) e "brazilian walnut", "cordia wood" e "jenny wood" em outros países (PIO CORREA, 1952).

Atualmente a distribuição natural conhecida da espécie é limitada à Amazônia Brasileira, porém é provável que ocorra em outros países como Bolívia e Peru, em virtudede constatações no Acre e Rondônia, e Venezuela e Guiana em face da sua presença em regiões fronteiriças de acordo com levantamen tos do Projeto RADAMBRASIL (CARPANEZZI e KANASHIRO, 1982). Em função dos conhecimentos atuais, os mesmos autores afirmamque o freijó ocorre em todos os Estados e Territórios da Amazônia clássica, porém ainda não foi possível delimitar preci= samente sua ārea de distribuição e conseqüentemente suas exigências edafo-climáticas em virtude da escassez de registros det a lhados.

Na Amazônia Brasileira, o freijó jā foi encontrado segundo a classificação de köppen nas condiçõescli máticas do tipo Afi que se caracteriza por chuvas relativamen te abundantes durante todo o ano, e por uma precipitação plu- 
viométrica superior a $60 \mathrm{~mm}$ nos meses mais secos; do tipo Ami cujo regime de chuvas anual determina uma estação relativamen te seca, entretanto, com total pluviométrico capaz de manter este período e finalmente o tipo Awi que se caracteriza por índice pluviométrico anual relativamente elevado, com estação seca bem definida.

Segundo CARPANEZzI (1980), no tocante a déficit hídrico, considerando o balanço de Thornthwaite \& Mather (capacidade de retenção de ägua pelo solo = $300 \mathrm{~mm}$ ), a espécie jā foi vista em áreas com pequenos déficit hídricos como no caso de Belém-Pará (15 mm), moderados déficit como em Belterra-Pará (110 mm) e elevados déficit como se verifica. em Altamira-Parā $(241 \mathrm{~mm})$. Os Iimites de precipitação em sua ārea de ocorrência estão entre $1.500 \mathrm{~mm}$ em Altamira-Parāe 2.500 mm em Belém-Pará, e em temperaturas médias anuais situam-sena faixa de 2490 a 289C (CARPANEZZI e KANASHIRO, 1982). Com relação à altitude DOI et alie (1975) informam ter detectado a ocorrência do freijó entre 5 m em Belém-Pará e 600 a 1.000 m no complexo Guianense.

Quanto às condições edäficas CARPANEZZI et alii (1983) e CARPANEZZI e KANASHIRO (1982) mencionam que a espēcie já foi encontrada em diversos tipos de solo como Latossolo Amarelo textura leve, Latossolo Amarelo textura muito argilosa e Terra Roxa Estruturada, porém pode ocorrer em outros solos face a sua ampla distribuição geogrā́fica.

A Cordia goeldiana possue características que 
lhe colocam em evidência entre as boas madeiras do Brasil e do mundo, substituindo nas construções até a madeira de teca (Tectona grandis L.) e segundo PIO CORREA (1952) e MAINIERI (1958) em certos casos, como na marcenaria de luxo, substitui perfeitamente o carvalho (2uercus rubor L.).

PIO CORREA (1952) e SLOOTEN et alii (1976) relatam que a madeira de freijó tem seu uso na construção de barcos e navios (para convēs, acabamentos e ornamentação, assoalhamento), carpintaria e construção em geral, assoalhos (in clusive para serviço pesado), marcenaria (para painéis, 1 ambris, móveis, caixilhos, persianas, esicadas, remos, etc) e mo biliário fino. Possue boa aceitação na indústria tanoeira e na construção aeronāutica, nas envergadura dos aviões e nas hêlices.

\section{2. Exigências nutricionais}

Uma das principais alternativas segundo BAULE (1975) para se obter um aumento de recursos florestais é sem dúvida o emprego de fertilizantes minerais, os quais poderão alterar os níveis de fertilidade do solo, de acordo com as exigências nutricionais da espécie arbórea a ser cultivada, adequando o solo à planta, entretanto para isso devem ser tam bém observadas outras técnicas de implantação e manejo.

A nutrição mineral é considerada por KRAMER e 
KOSLOWSKI (1960) como um fator muito importante da fisiologia da árvore, porque o suprimento adequado de certos elementos minerais é essencial para o sucesso do seu crescimento. Por outro lado, segundo BALLONI (1984) a integração entre a experimentação, anālise do solo e anālise foliar, podem fornecer os subsídios para uma orientação segura das necessidades nutricionais das espécies florestais.

No Brasil, o conhecimento das exigências nutricionais das diversas espécies florestais é relativamente pequeno e na maioria das vezes limitado a algumas espécies em condições específicas de solo, uma vez que os primeiros expe: rimentos sobre nutrição em florestas iniciaram por volta de 1960, através de trabalhos de BRASIL SOBRINHO et alie (1961),

HAAG et alii (1961 a e b) MELLO et alii (1960) e MELLO et alii (1961). Atualmente, a pesquisa na ārea de nutrição florestal particularmente a anālise de tecido para fins de diagnóstico de avaliação do estado nutricional, tem recebido um incentivo muito grande em face do uso de fertilizantes na ärea florestal.

2.2.1. Concentração de nutrientes

A concentração dos nutrientes nas diferentes partes da planta, segundo CURLIN (1970), obedece a seguinte ordem decrescente: folhas, ramos, lenho e raízes. Contu- 
do, o autor considera que, em geral, a distribuição da fitomassa se processa em maior quantidade no lenho, seguido de raízes, ramos, casca e folhas.

Diversas são as causas que podem influenciar a concentração de nutrientes, entre elas a espécie, diferenças entre procedências, progênies e clones (FORREST e OVINGTON, 1971; BARTOS e JOHNSTON, 1978), idade (SWITZER e NELSON, 1972), fertilidade do solo (PRITCHETf, 1979), estação do ano (WHITACKER, 1975), umidade do solo (SHOULDERS, 1981) e densidade de plantio (SWITZER et alii, 1968) dai as diferenças verificadas nos trabalhos mencionados na presente revisão a seguir.

2.2.1.1. Experimentos em condições de casa de veget ação

Utilizando mudas de um ano de idade de Pinus taeda L. e Pinus virginiana Mill para estudos de nutrição mineral em substrato de areia com irrigação automática e diversas doses de nitrogênio e fósforo FOWELLS e KRAUSS (1959) verifica ram após cinqüenta semanas, que ambas as espécies apresentavam melhor crescimento quando o $N$ era suprido de forma constante a doses de 25 e 100 ppm. As diferenças entre as respos tas às doses de 25 ppm e entre 25 e 100 ppm, sendomuito pequenas permitiam levar à afirmação de que valores entre 25 e 100 ppm representavam bom nível de N. Um suprimento constante de 1 ppm de $\mathrm{P}_{2} \mathrm{O}_{5}$ revelou ser um nível adequado ao crescimento das duas espécies. A anālise foliar mostrou que as concen- 
trações de 1,7 a $2,3 \%$ de $N$ e 0,14 a $0,16 \%$ de $P$ nas folhas des tas espécies, indica uma nutrição satisfatōria para estes ele mentos.

\section{SUCOFF (1961) trabalhou com Pinus taeda}

e

Pinus virginiana em condições de vasos, com o objetivo de verificar sintomas de deficiência de $\mathrm{K}, \mathrm{Ca}$ e Mg. Determinou que os sintomas de carência de K estavam associados a teores de 0,16 a $0,26 \%$ do elemento nas acículas. A concentração do $\mathrm{Mg}$ nas acículas das plantas deficientes variou de 0,006 a 0,08\%, enquanto que para o $\mathrm{Ca}$ as concentrações eram menores de $0,033 \%$. Uma série de experimentos foram desenvolvidos no Instituto de Pesquisa Florestal de Rotorua em Nova Zelândia, visando o estabelecimento de métodos para a cultura de Eucalipto naquele país. Entre eles foi realizado um ensaio por WILL (1961a) o qual utilizou as espécies Eucalyptus pilularis, Eucalyptus botryoides e Eucalyptus saligna em condições de viveiro e em solução nutritiva com a finalidade de ve rificar a concentração de $N, P$ e K nas folhas dessas espécies na ausência e presença dos respectivos elementos, obtendo cos seguintes resultados: Eucalyptus pilularis - 1,24 e $1,66 \%$ de $\mathrm{N} ; 0,08$ a $0,24 \%$ de $\mathrm{P}$ e 0,35 e $1,90 \%$ de $\mathrm{K}$. Eucalyptus botryoides - 1,40 e $1,81 \%$ de $N$; 0,08 e $0,16 \%$ de $P$ e 0,36 e $1,60 \%$ de K. Eucalyptus saligna $-1,70$ e $1,90 \%$ de $N ; 0,09$ e $0,22 \%$ de $P$ e 0,37 e $1,90 \%$ de $K$. Concluiu que o Eucalyptus saligna apresentou uma maior concentração de $N$ quando comparado com as outras 
espëcies estudadas, enquanto que para $P$ e $K$ as concentrações se equivaleram.

WILL (1961b), cultivando Pinus radiata D.Don em vaso observou que as quantidades de 100 ppm de N, 1 ppm de P, 10 ppm de $K$ e 10 ppm de $M g$ na solução nutritiva, foram suficientes para manter bom crescimento das plantas. Concluiu através da anālise química que os teores foliares de $1,6 \%$ de $N, 0,1 \%$ de $\mathrm{P}, 1,1 \%$ de $\mathrm{K}$ e $0,11 \%$ de $\mathrm{Mg}$ indicaram suprimentos adequados de cada nutriente:-

HAAG et alii (1961a) realizaram estudos sobre a alimentação mineral do Eucalyptus alba desenvolvendo ensaio em vasos com areia lavada e solução nutritiva com o objetivo de estudar os efeitos das deficiências de macronutrientes $N$, $\mathrm{P}, \mathrm{K}, \mathrm{Ca}, \mathrm{Mg}$ e $\mathrm{S}$ no aspecto crescimento e composição química do Eucalyptus alba Reinw. Os resultados mostraram diferentes niveis do elemento nos tratamentos com omissão e completo nas diversas partes da planta: Folhas superiores - 0,84 e $1,73 \%$ de $N ; 0,09$ e $0,12 \%$ de $P ; 0,70$ e $1,13 \%$ de $K ; 0,16$ e $0,30 \%$ de Ca; 0,21 e $0,52 \%$ de $M g$ e 0,16 e $0,26 \%$ de S. Folhas infe$\underline{\text { riores }}-0,89$ e $1,23 \%$ de $N ; 0,05$ e $0,10 \%$ de $P ; 0,55$ $0,95 \%$ de $\mathrm{K} ; 0,32$ e $0,34 \%$ de $\mathrm{Ca} ; 0,21$ e $0,51 \%$ de $\mathrm{Mg}$ e 0,09 e $0,26 \%$ de S. Ramos $-0,61$ e $0,67 \%$ de $N ; 0,05$ e $0,22 \%$ de P; 0,40 e $0,84 \%$ de $\mathrm{K} ; 0,38$ e $0,62 \%$ de Ca; 0,11 e $0,36 \%$ de Mg e 0,16 e $0,19 \%$ de S. Caule $-0,50$ e $0,56 \%$ de $N ; 0,04$ e $0,13 \%$ de P; 0,20 e $0,75 \%$ de K; 0,14 e $0,24 \%$ de Ca; 0,14 e $0,27 \%$ de $\mathrm{Mg}$, traços e $0,15 \%$ de S. Raiz $-0,56$ e $0,61 \%$ de $\mathrm{N} ; 0,05$ 
e $0,18 \%$ de P; 0,25 e $0,55 \%$ de K; 0,08 e $0,22 \%$ de $\mathrm{Ca} ; 0,13$ e $0,28 \%$ de $\mathrm{Mg}$ e 0,04 e $0,18 \%$ de $S$. Os autores concluiram que comparando com os resultados analíticos obtidos no presente ex perimento com os provenientes de material cultivado em. condições de campo (HAAG et alii, 1961b) os primeiros podem ser de utilidade para o reconhecimento de deficiências minerais nas plantações de Eucalipto.

Conduzindo trabalho experimental em vaso com solos deficientes em N, GONZALES ESPARCIA e GARCIA NUÑo (1964) estabeleceram correlação entre crescimento medido através doc peso seco e concentração do elemento nas folhas e verificaram que a concentração crítica de $\mathrm{N}$ em Eucalyptus globulus é da ordem de $1,65 \%$ enquanto que em Eucalyptus rostrata é de 1,5\%. MALAVolta et alii (1964) estudaram o efeito do nitrogênio, fósforo e potássio no crescimento e composição quí mica do Pinnus elliottii Engelmenn cultivado em solução nutritiva, em vasos contendo substrato de sílica. Foram empregadas mudas de 1 ano de idadeque se achavam repicadas em laminados com solo, provenientes do Horto Florestal de Tupi em Piracicaba-S.P.. O ensaio consistiu num fatorial com 3 ní veis de $N(25,50$ e $100 \mathrm{ppm}), P(5,10$ e $20 \mathrm{ppm})$ e $K(25,50$ e $100 \mathrm{ppm}$ ), sendo os outros nutrientes fornecidos em niveis constantes. Com base nos resultados obtidos os autores concluíram que os sintomas de deficiência do N, P e K apareceram primeiramente nas acículas velhas e são concordantes com os obtidos em outras espécies de Pinus L.; a análise química dos di 
versos órgãos avalia o estado nutricional do Pinus e serve de confirmação ao diagnöstico visual; os resultados sugerem que o melhor tratamento no substrato consistiu em 100 ppm de $\mathrm{N}, 10$ ppm de $\mathrm{P}$ e $50 \mathrm{ppm}$ de $\mathrm{K}$ mais os outros macro e micronutrientes nos níveis estabelecidos; nas condições de ensaio o $N$ proporcionou maior aumento no crescimento, traduzido pelo aumento em altura e peso da matéria seca, enquanto que o $P$ e $K$ tiveram efeito menor.

Com a finalidade de avaliar a composição química do Eucalipto (híbrido) na fase inicial de desenvolvimento e cultivado em solução nutritiva submetido a : tratamentos com omissão de $N, P, K, C a, M g$ e $S$ e na presença de todos os nutrientes, KAUL et alii (1966) encontraram os seguintes resul tados, respectivamente: 1,20 e $1,97 \%$ de $N ; 0,20$ e $0,34 \%$ de P; $1,18 \%$ e $2,29 \%$ de K; 0,66 e $1,48 \%$ de Ca; 0,13 e 0,26\% de Mg e 1,40 e $1,48 \%$ de S. Em 1968, KAUL et alii desenvolveram o mesmo tipo de ensaio, entretanto, utilizaram a espécie Eucalyptus. grandis e obtiveram os seguintes teores: 1,15 e $2,38 \%$ de $\quad$; 0,08 e $0,21 \%$ de $P ; 0,40$ e $0,80 \%$ de $K ; 0,56$ e $0,84 \%$ de $\mathrm{Ca}$; 0,12 e $0,29 \%$ de $M g$ e 0,17 e $0,33 \%$ de S, respectivamente.

Para verificar os efeitos da omissão de nutrientes na nutrição mineral do "pinheiro do Paranā", Araucaria angustifolia (Bert.) o.ktze., SIMÕES (1973) desenvolveu um experimento em condições de vasos, com substrato de sílica e em solução nutritiva por um período de dois anos. os resultados mostraram níveis diferentes do elemento nos tratamentos 
com ausência e completo nas partes das plantas estudadas: Par te aérea $-0,66$ e $0,87 \%$ de $N ; 0,10$ e $0,23 \%$ de $P ; 0,23$ e $0,72 \%$ de K; 0,32 e $0,76 \%$ de Ca; 0,06 a $0,21 \%$ de $M g$ e 0,04 e $0,06 \%$ de S. Sistema radicular $-0,48$ e $0,63 \%$ de $N ; 0,11$ e $0,18 \%$ de P; 0,19 e $0,41 \%$ de $\mathrm{K} ; 0,21$ e $0,33 \%$ de Ca; 0,04 e 0,12 de $\mathrm{Mge} 0,04$ e $0,07 \%$ de $\mathrm{S}$.

Após a análise dos resultados o autor concluiu que todos os tratamentos afetaram o crescimento das mudas exceção feita apenas à tratamento com omissão de S; a omissão de $N$, além de limitar o crescimento das plantas e diâmetro do caule,provocou forte clorose nas folhás; a omissão de P, 1imitou também o crescimento e diâmetro do caule e provocou cres tamento e morte das folhas. e ramos; a omissão de $\mathrm{N}, \mathrm{P}$ e $\mathrm{Mg}$ reduziram o crescimento das raízes; a omissão de $\mathrm{K}$ aumentou o teor de $\mathrm{Ca}$ nas partes aéreas da planta; a omissão de Ca resultoú em absorção muito baixa de $\mathrm{N}$ $(0,65 \%)$; a omissão de $\mathrm{N}$ induziu a um aumento relativo do nível de $\mathbf{P}$ $(0,30 \%), \mathrm{K}(1,18 \%)$ e e $\mathrm{Ca}(0,85 \%)$; a omissão de $\mathrm{Ca}$ e de $\mathrm{K}$ aumentou sensivel. mente o teor de Mg na parte aérea das plantas.

ROCHA FILHO et alii (1978b) cultivaram mudas de Eucalyptus urophylla em soluções nutritivas carente nos macro e micronutrientes com o objetivo de observar a influência da omissão e presença dos nutrientes sobre o crescimento e compo sição química das folhas superiores, medianas e inferiores, as sim como do caule e raízes. Os resultados alcançados evidenciaram diferentes níveis do elemento nos tratamentos com omis são e presença nas diversas partes da planta, respectivamente: 
Eolhas superiores $=0,72$ e $2,67 \%$ de $N ; 0,04$ e $0,22 \%$ de P;0,09 e $1,78 \%$ de K; 0,04 e $0,64 \%$ de Ca; 0,04 e $0,17 \%$ de $M g$ e 0,05 e $0,11 \%$ de S; 8,25 e 30,5 ppm de B 950 e 139 ppm de Fe. Folhas medianas $-0,60$ e $3,16 \%$ de $N ; 0,03$ e $0,19 \%$ de $P ; 0,13$ e $1,88 \%$ de K; 0,10 e $0,80 \%$ de Ca; 0,04 e $0,13 \%$ de $\mathrm{Mg}$ e 0,06 e $0,10 \%$ de S; 10 e 26 ppm de B e 169 e 231 ppm de Fe. Foihas inferiores 0,69 e $2,10 \%$ de $N ; 0,04$ e $0,22 \%$ de $P ; 0,14$ e 2,10\% de K; 0,22 e $1,30 \%$ de $\mathrm{Ca} ; 0,05$ e $0,19 \%$ de $\mathrm{Mg} ; 0,07$ e $0,08 \%$ de S, 20 e 55 ppm de B e 214 e 422 ppm de Fe. Caule - 0,32 e 1,23\% de N; 0,04 e $0,17 \%$ de $P ; 0,08$ e $1,28 \%$ de $K ; 0,08$ e $0,94 \%$ de Ca;0,01 e $0,11 \%$ de $M g ; 0,02$ e $0,04 \%$ de S, 8 e 22 ppm de B e 56 e 145 ppm de Fe. $\underline{\text { Raiz }}-0,65$ e 2,50 de N; 0,04 e $0,68 \%$ de P; 0,08 e $1,10 \%$ de $K ; 0,01$ e $1,64 \%$ de Ca;0,01 e 0,15\% de Mg; 0,09 e $0,18 \%$ de S, 22 e 59 ppm de B e 805 e 1306 ppm de Fe.

Verificaram que a omissão de nutrientes afe= tou sensivelmente o crescimento das plantas, exceção feita pa ra o enxofre que apresentou uma produção de matéria seca maior. que a produzida pela plantas cultivadas no tratamento completo. O tratamento com omissão de $N$ foi o que mostrou maior efei to depressivo no crescimento. As plantas apresentaram sintomas de carência quando os níveis dos elementos nas folhas acu sam os seguintes valores: $\mathrm{N}-0,69 \% ; \mathrm{P}-0,04 \% ; \mathrm{K}-0,14 \% ; \mathrm{Ca}$ $-0,04 \% ; \mathrm{Mg}-0,05 \% ; \mathrm{S}<0,05 \%$ 。

Haag (1965) citado por BELLOTTE (1979), estudando micronutrientes em mudas de Eucalyptus terenticornis e apōs analisar a composição química das folhas superiores e 
inferiores, encontrou teores, respectivamente para os seguin tes elementos: 83 e 176 ppm de B; traços e 17,2 ppm de Cu; 164 e 310 ppm de Fe; traços e 113 ppm de Mn; 0,47 e 2,20 ppm de Mo e 15,70 e 15,50 ppm de $Z n$.

Com o objetivo de estudar o crescimento inicial e composição química da Gmelina arborea Roxb. HAAG et alii (1981) cultivaram mudas dessa espécie em solução nutritivaten do como substrato silica moída e submetidas aos tratamentos com omissão de $\mathrm{N}, \mathrm{P}, \mathrm{K}, \mathrm{Ca}, \mathrm{Mg}, \mathrm{S}, \mathrm{B}$ e presença de todos os nutrientes. Quando as plantas apresentaram sintomas evidentes de carência, foram coletadas, divididas em folhas novas, foIhas maduras, caule, raiz e pesadas e analisadas para os ele mentos em questão, obtendo os seguintes teores: Folhas novas0,88 e $3,00 \%$ de $N ; 0,14$ e $0,20 \%$ de P; 0,53 e $1,85 \%$ de K; 0,31 e $1,10 \%$ de Ca; 0,20 e 0,52\% de $\mathrm{Mg} ; 0,03$ e $0,16 \%$ de S e 13 e 128 ppm de B. Folhas maduras $-0,87$ e $2,70 \%$ de $\mathrm{N} ; 0,10$ e $0,15 \%$ de P; 0,33 e 2,00\% de K; 0,64 e $1,30 \%$ de Ca; 0,07 e $0,52 \%$ de $M g ; 0,07$ e $0,18 \%$ de $\mathrm{S}$ e 28 e 71 ppm de B. Caule 0,37 e $2,00 \%$ de $N ; 0,08$ e $0,15 \%$ de $P ; 0,15$ e $1,60 \%$ de $K ; 0,12$ e $0,40 \%$ de $\mathrm{Ca} ; 0,07$ e $0,22 \%$ de $\mathrm{Mg} ; 0,08$ e $0,12 \%$ de $\mathrm{S}$ e 5 e 20 ppm de B. $\underline{\text { Raiz }}-0,61$ e $1,40 \%$ de $N ; 0,09$ e $0,15 \%$ de P; 0,16 e $1,70 \%$ de K; 0,08 e $0,28 \%$ de Ca; 0,05 e $0,17 \%$ de $\mathrm{Mg} ; 0,04$ e $0,14 \%$ de Se 4 e 13 ppm de B. Os autores observaram que a omis são dos nutrientes afetou o crescimento da planta, sendo que o S foi o elemento mais limitante. 
2.1.1.2. Experimentos em condições de campo

Estudando o teor de $K$ em folhas coletadas de povoamentos de Eucalyptus camaldulensis e Eucalyptus gomphoce phala. METRO e BEAUCORPS (1958) encontraram valores oscilando na matéria seca em torno de $0,60 \%$ e $0,62 \%$, respectivamente. Para conhecer a composição química do Pinus elliottii, Engelmann, MELLO et alii (1960) coletaram plantas de uma população com 4 anos de idade no Horto Florestal de Tu pi em Piracicaba - Estado de São Paulo, instalada em um solo da formação Corumbatai. As plantas depois de cuidadosamente co letadas foram divididas em folhas, galhos ou ramos, caule e raízes e pesadas separadamente para obtenção do peso seco e posteriormente analisadas para determinação da concentração de $\mathrm{N}, \mathrm{P}, \mathrm{K}, \mathrm{Ca}$ e Mg contido nas diversas partes. Os resultados obtidos indicaram os seguintes teores: - Folhas - 1,23\% de N; $0,08 \%$ de P; $0,35 \%$ de K; 0,21\% de Ca e 0,12\% de Mg. Galhos ou ramos $-0,56 \%$ de $N ; 0,08 \%$ de $P ; 0,20 \%$ de $K ; 0,01 \%$ de Ca e $0,10 \%$ de Mg, $\underline{\text { Caule }}-0,42 \%$ de N;0,06\% de P; $0,19 \%$ de K; $0,13 \%$ de Ca e $0,12 \%$ de $\mathrm{Mg}$. Raízes $-0,70 \%$ de $\mathrm{N} ; 0,07 \%$ de P; 0,25\% de $\mathrm{K} ; 0,17 \%$ de Ca e $0,10 \%$ de $\mathrm{Mg}$. Os autores concluíram que o Pinus elliottii apresenta baixas concentraçôes com relação aos macronutrientes analisados.

HAAG et alii (1961b) tomaram plantas de Eucalyptus alba Reinw e Eucalyptus grandis (Mi11.) Maiden, provenientes de povoamento de 2 anos de idade situados num solo de cerrado. No laboratório as plantas foram divididas em folhas, galhos ou 
ramos, caule e raízes e posteriormente pesadas e submetidas à secagem até atingir peso constante para depois de moídas, serem analisadas para obtenção dos teores de N, P, K, Ca e Mg. Os resultados alcançados mostraram as seguintes concentrações nas diferentes partes da planta para Eucalyptus alba: Folhas $2,07 \%$ de $\mathrm{N} ; 0,19 \%$ de $\mathrm{P} ; 1,04 \%$ de $\mathrm{K} ; 1,28 \%$ de $\mathrm{Ca}$ e 0,43\% de Mg. Galhos ou ramos - $0,67 \%$ de N;0,13\% de P; 0,83\% de K; 1,14\% de Ca e 0,24\% de Mg. Caule $-0,41 \%$ de N; 0,06\% de P;0,35\% de $\mathrm{K}$; $0,91 \%$ de Ca e 0,19\% de Mg, Rai.z - 0,54\% de N; 0,07\% de P; $0,43 \%$ de K; $0,92 \%$ de Ca e $0,21 \%$ de Mg. Os teores encontrados para Eucalyptus grandis foram: Folhas- $2,22 \%$ de $N ; 0,17 \%$ de $\mathrm{P} ; 1,14 \%$ de K; $1,15 \%$ de Ca e $0,44 \%$ de Mg. Galhos ou ramos $0,55 \%$ de $N$; $0,09 \%$ de P; 0,57\% de K; 1,06\% de Ca e 0,21\% de Mg. Caule $-0,39 \%$ de N; $0,06 \%$ de P; $0,48 \%$ de K; $0,92 \%$ de Ca e $0,20 \%$ de Mg. Raiz - 0,60\% de N;0,10\% de P;0,42\% de K; $1,01 \% \mathrm{Ca}$ e $0,23 \%$ de $\mathrm{Mg}$. Os autores observaram através dos resultados obtidos que o Eucalyptus alba e o Eucalyptus grandis são mais exigentes em $\mathrm{Ca}, \mathrm{N}$ e $\mathrm{K}$ e menos em $\mathrm{Mg}$ e $\mathrm{P}$.

Através da análise foliar HAG et alii (1976) estudaram cinco espécies de Eucaliptos estabelecidos em dois povoamentos com 7 anos de idade em solos do município de Mogi-Guaçu (Latossolo Vermelho-amarelo-barro argilo arenoso), e Areia Branca (Latossolo Vermelho-amarelo - barro arenoso) no Estado de São Paulo. Após as análises químicas observaram os seguintes teores de macronutrientes, respectivamente em função do tipo de solo: Eucalyptus grandis - 2,26 e $1,97 \%$ de $N$; 
0,12 e $0,11 \%$ de $P$; 0,58 e $0,38 \%$ de $K ; 0,38$ e $0,41 \%$ de Ca;0,15 e $0,15 \%$ de $\mathrm{Mg}$ e 0,24 e $0,26 \%$ de $\mathrm{s}$. Eucalyptus microcorys $-1,70$ e $1,21 \%$ de $N ; 0,08$ e $0,08 \%$ de $P ; 0,37$ e $0,17 \%$ de $K ; 0,24$ e $0,30 \%$ de $\mathrm{Ca} ; 0,09$ e $0,12 \%$ de $\mathrm{Mge} 0,28$ e 0,12\% de S. Eucalyptus resinifera $-1,54$ e $1,28 \%$ de $N ; 0,09$ e $0,06 \%$ de P; 0,49 e $0,31 \%$ de K; 0,33 e $0,28 \%$ de Ca; 0,12 e $0,11 \%$ de $M g$ e 0,22 e $0,15 \%$ de S. Eucalyptus robusta - 1,62 e $1,40 \%$ de $\mathrm{N} ; 0,09$ e $0,08 \%$ de P; 0,55 e $0,38 \%$ de $K ; 0,46$ e $0,54 \%$ de Ca; 0,16 e $0,17 \%$ de Mge 0,21 e 0,12\% de S. Eucalyptus saligna - 1,91 e $1,62 \%$ de $N ; 0,11$ e $0,09 \%$ de $P ; 0,52$ e $0,33 \%$ de $K ; 0,22$ e $0,36 \%$ de Ca; 0,14 e $0,16 \%$ de $\mathrm{Mge} 0,20$ e 0,16\% de S. Concluíram que as concentrações mais elevadas de $\mathrm{N}, \mathrm{P}, \mathrm{K}, \mathrm{e} \mathrm{S}$ são, encontradas no Eucalyptus grandis e que as mais baixas com exceção do s, são encontradas no Eucalyptus microcorys. Por outro lado, os Eucaliptos da região de Mogi-Guaçu apresentam concentrações mais elevadas nos macronutrientes $N, P, K$ e S .

Os mesmos autores, determinaram também a concentração dos micronutrientes nas folhas, expressa em ppm na matéria seca e obtiveram os seguintes resultados considerando os solos que ocorrem em Mogi-Guaçu e Areia Branca, respectiva mente: Eucalyptus grandis -18 e 27 ppm de B; 6 e 6 ppm de $\mathrm{Cu} ; 98$ e 90 ppm de Fe; 452 e 466 ppm de Mn e 39 e 34 ppm - de $\mathrm{Zn}$. Eucalyptus microcorys -18 e 19 ppm de B; 7 e 6 ppm Cu; 78 e 65 ppm de Fe; 373 e 352 ppm de Mne 32 e 26 ppm de Zn. Eucalyptus resinifera - 22 e 19 ppm de B; 6 e 5 ppm de Cu; 95 e $72 \mathrm{ppm}$ de Fe; 315 e 374 ppm de Mn e 37 e 36 ppm de $\mathbf{Z n}$. 
Eucalyptus robusta -28 e 29 ppm de B; 8 e 7 ppm de Cu; 78 e 87 ppm de Fe; 348 e 542 ppm de Mne 33 e 38 ppm de $2 n$. Eucalyp tus saligna - 18 e 34 ppm de B; 6 e 6 ppm de Cu; 80 e 69 ppm de Fe; 296 e 500 ppm de Mne 36 e 38 ppm de Zn. Concluíram que as espécies de Eucaliptos não mostram diferença nos teores dos micronutrientes nas folhas.

objetivando determinar as concentrações de macronutrientes e micronutrientes em algumas espécies florestais do Parque da Escola Superior de Agricultura "Luiz de Queiroz", em Piracicaba - S.P., DALL'ORTO et alii (1976) coletaram folhas de ärvores adultas de Aleurites moluccana (Lineu) Willd. conhecida como "nogueira de iguape", Cariniana estrellensis (Raddi) 0. Ketze. conhecida como "jequitibä bran co", Tabebuia roseo-alba sin. Paratecoma peroba Record conhecida como "ipê branco" (localizadas em solo do tipo Terra Roxa Estruturada), Piptadenia rigida conhecida como "angico bran co" (desconhece-se a caracterização química do solo onde se achava implantada, porém segundo os autores possui como material de origem o folhelho) e Aspidosperma polyneuron Müell conhecida como "peroba" (localizada em solo Hidromórfico, des conhecendo-se a caracterização química, entretanto, possui co mo material de origem o folhelho). Após a análise química do material os resultados mostraram as seguintes concentrações na matéria seca: "Angico branco" - 2,08\% de $\mathrm{N} ; 0,05 \%$ de $\mathrm{P} ; 0,55 \%$ de $\mathrm{K} ; 0,87 \%$ de Ca;0,22\% de Mg; 6 ppm de Cu; 565 ppm de Fe; 262 ppm de Mn e 76 ppm de Zn . "Nogueira-de-iguape" $-2,51 \%$ de 
$\mathrm{N} ; 0,16 \%$ de $\mathrm{P} ; 1,81 \%$ de $\mathrm{K} ; 1,39 \%$ de $\mathrm{Ca} ; 0,51 \%$ de $\mathrm{Mg} ; 6$ ppm de Cu; 95 ppm de Fe; 193 ppm de Mn e 24 ppm de Zn. "Jequetibäbran co" $-2,02 \%$ de $N ; 0,08 \%$ de P; $0,86 \%$ de $K ; 1,31 \%$ de Ca; $0,49 \%$ de Mg; 7 ppm de Cu; 211 ppm de Fe; 379 ppm de Mn e 24 ppm de Zn. "Ipêe branco" - 1,55\% de N;0,14\% de P; 1,17\% de K; 2,14\% de Ca;0,31\% Mg; 5 ppm de Cu; 124 ppm de Fe; 57 ppm de Mn e 28 ppm de Zn. "Peroba" - 1,63\% de N;0,23\% de P; 1,44\% de $\mathrm{K}$; $1,62 \%$ de Ca; $0,39 \% \mathrm{Mg} ; 12 \mathrm{ppm} \mathrm{de} \mathrm{Cu;139} \mathrm{ppmde} \mathrm{Fe;} 60$ ppm de Mn e 25 ppm de Zn. Os autores concluiram que em todas as espécies estudadas, com exceção da Aleurites moluccana ou "noguei ra-de-iguape", os nutrientes constatados em concentrações mais elevadas foram o $N$ e o Ca, enquanto que nesta espécie observou-se uma concentração maior para $\dot{N}$ e K. As ärvores pertinentes às espécies Piptadenia rígida "angico branco" Cariniana estrellensis "jequetibà branco" mostraram concentrações particularmente elevadas de Fe.

Analisando folhas sadias de plantas adultas de Eucalyptus obliqua coletadas em tểs diferentes äreas da Tasmânia NIELSEN e PALZER (1977), observaram concentrações de nu trientes oscilando entre $1,27-1,66 \% \operatorname{para} \mathrm{N} ; 0,75-0,82 \%$ pa ra $P ; 0,33-0,56 \%$ para K; $0,62-0,78 \%$ para Ca e 0,28-0,31\% para $\mathrm{Mg}$.

Estudando a concentração de nutrientes em foThas de Eucalyptus citriodora provenientes de um povoamento de aproximadamente. 4 anos de idade, localizado em solodo tipo Regossolo, situado no município de Santa Maria da Serra, 
no Estado de São Paulo, HAAG et alii (1977) encontraram em fo lhas sadias os seguintes teores para macro e micronutrientes: $\mathrm{N}-1,38 \% ; \mathrm{P}-0,07 \% ; \mathrm{K}-1,38 \% ; \mathrm{Ca}-0,17 \% ; \mathrm{Mg}-0,18 \% ; \mathrm{S}-$ $0,06 \% ; \mathrm{B}-18 \mathrm{ppm} ; \mathrm{Cu}-7 \mathrm{ppm} ; \mathrm{Fe}-127 \mathrm{ppm} ; \mathrm{Mn}-390 \mathrm{ppm} ; \mathrm{Zn}$ - 18 ppm. Em virtude de na mesma ärea existir certo número de plantas de cedro (Cedrela fissilis, Ve11) no povoamento, os autores aproveitaram para analisar folhas novas e maduras encontrando os seguintes resultados, respectivamente: $N \quad-\quad 2,48$ e $2,35 \% ; P-0,13$ e $0,13 \% ; K-0,74$ e $0,81 \% ; C a-0,63 \ldots$ e $0,68 \% ; \mathrm{Mg}-0,27$ e $0,27 \% ; \mathrm{S}-0,25$ e $0,27 \% ; \mathrm{B}-18$ e 16 ppm; $\mathrm{Cu}-8$ e 8 ppm; Fe - 216 e $177 ; \mathrm{Mn}-52$ e 54 ppm; Zn - 21 e 23 ppm. Observaram através dos dados analíticos valores elevados em $\mathrm{N}$ e $\mathrm{Mg}$ e inferiores em $\mathrm{B}$, $\mathrm{Mn}$ e $\mathrm{Zn}$ quando confrontados com os encontrados em Eucalyptus citriodora.

\section{ROCHA FILHO et alii (1978a) verificaram o teor} de nutrientes nas folhas de Eucalyptus citriodora com * 24 anos de idade em dois povoamentos situados em um solo Podzólico Vermelho-Amarelo variação Laras no município de Piracicaba, Estado de São Paulo. Para um melhor conhecimento da mobilidade dos nutrientes, as amostras foram divididas em folhas novas, maduras e velhas, sendo observadas as seguintes concentrações, respectivamente: Eucalyptus citriodora - 1,71, 1,38 e $0,86 \%$ de $N$; $0,09,0,10$ e $0,08 \%$ de $P ; 1,53,1,23$ e $0,86 \%$ de K; $0,46,0,74$ e $0,81 \%$ de Ca; $0,23,0,16$ e $0,11 \%$ de Mg;0,12, 0,12 e $0,10 \%$ de S; 37, 52 e 49 ppm de B; 11, 7 e 6 ppm de Cu; 77,167 e 131 ppm de Fe; 412, 725 e 830 ppm de Mn e 27, 23 e 
$32 \mathrm{ppm}$ de $\mathrm{Zn}$. Pinus taeda $-1,16,1,06$ e $0,81 \%$ de $\mathrm{N} ; 0,09$, 0,07 e $0,05 \%$ de P; $0,45,0,32$ e $0,42 \%$ de $K ; 0,29,0,50$ e $0,57 \%$ $\mathrm{Ca} ; 0,14,0,19$ e $0,13 \%$ de $\mathrm{Mg} ; 0,13,0,12$ e $0,11 \%$ de S; 37 , 30 e 25 ppm de B; 5, 3 e 5 ppm de Cu; 100, 149 e 250 ppm de Fe; 476,700 e 426 ppm de Mn e 23,23 e 20 ppm de $\mathrm{Zn}$. Os autores concluíram que o Eucalyptus citriodora apresenta-se mais exigente que o Pinus taeda em relação aos nutrientes. Eucalyptus citriodora contribuiu em maior proporção para enriquecer o solo em $\mathrm{K}$ e em $\mathrm{Mg}$.

Em diferentes localidades da India, BHIMAyA e KAUL (1966), observaram sintomas de deficiência de alguns micronutrientes em populações de Eucalyptus camaldulensis

após coletar folhas com e sem sintomatologia dos diversos ele mentos e analisá-las quimicamente obtiveram, respectivamente: 8,0 e 10,3 ppm de Cu; 141 e 146 ppm de Fe; 77 e 105 ppm de Mn e 12,6 e $20,3 \mathrm{ppm}$ de $\mathrm{Zn}$.

CASTRO et alii (1980) estudaram a distribuição de nutrientes em Pinus oocarpa com 8 anos de idade, localizado na Companhia Agro-Florestal Monte Alegre, no município de Agudos, Estado de São Paulo e instalado em Latossolo Verme 1ho-Amarelo fase arenosa. Após a derrubada das ārvores foram separadas nos seguintes componentes: acículas, ramos, casca e madeira do tronco. Os resultados alcançados mostraram concentrações diferentes nas diversas partes da planta: Aciculas - $1,59 \%$ de N; $0,08 \%$ de P; $0,54 \%$ de K; $0,18 \%$ de Ca; $0,08 \%$ de Mg; 232 ppm de Fe; 217 ppm de Mne 16 ppm de Zn。 Ramos - 0,37\% 
de $\mathrm{N} ; 0,02 \%$ de $\mathrm{P} ; 0,20 \%$ de $\mathrm{K} ; 0,12 \%$ de $\mathrm{Ca} ; 0,04 \%$ de $\mathrm{Mg} ; \quad 66$ ppm de Fe; 104 ppm de Mn e 13 ppm de Zn . Casca - 0,30\% de N; $0,02 \%$ de P; $0,12 \%$ de K; $0,12 \%$ de Ca; $0,02 \%$ de Mg; 68 ppm de Fe; 32 ppm de Mn e 7 ppm de Zn. Madeira do tronco - 0,13\% de $\mathrm{N} ; 0,01 \%$ de P; $0,09 \%$ de $\mathrm{K} ; 0,05 \%$ de Ca; $0,02 \%$ de $\mathrm{Mg} ; 23$ ppm de Fe; 56 ppm de Mne 7 ppm de $Z n$. Com base nos resultados verificaram que as acículas contêm maior concentração em todos os nutrientes enquanto que a madeira do tronco apresenta as menores concentrações. Observaram que a ordem relativa dos teores de nutrientes obedece a seguinte seqüência: $\mathrm{N}>\mathrm{K}>\mathrm{Ca}$ $>\mathrm{P}=\mathrm{Mg}>\mathrm{Fe}=\mathrm{Mn}>\mathrm{Zn}$, no componente acícula. A casca apre senta a seguinte ordem: $\mathrm{N}>\mathrm{K}=\mathrm{Ca}>\mathrm{Mg}=\mathrm{P}>\mathrm{Fe}>\mathrm{Mn}>\mathrm{Zn}$. Para ramos e madeira do tronco, a seqüència é: $\mathrm{N}>\mathrm{K}=\mathrm{Ca}>$ $\mathrm{Mg}>\mathrm{P}>\mathrm{Mn}>\mathrm{Fe}>\mathrm{Zn}$.

Os autores compararam os resultados com os obtidos por EGUNJOBI e BADA (1979) trabalhando com Pinus caribaea, Morelet de 10 anos de idade na Nigéria os quais obtiveram as seguintes concentrações nas acículas: $0,87 \%$ de $N ; 0,03 \%$ de $P ; 0,75 \%$ de $\mathrm{K} ; 0,35 \%$ de $\mathrm{Ca}$ e. $0,18 \%$ de $\mathrm{Mg}$. Observaram que o Pinus oocar pa mostra uma concentração de $N$ e $P$ distintamente superiorpo rëm com concentrações de $\mathrm{K}, \mathrm{Ca}$ e Mg inferiores.

Procedendo a um estudo de anālise foliar em Gmelina arborea com 6,5 anos de idade, Evans (1979) co letou folhas maduras de vārias posições da ārvore é expostas ao sol e encontrou os seguintes valores: $2,15 \%$ para $N, 0,14 \%$ 
para P, 1,20\% para K, 1,40\% para Ca, 0,30\% para Mg, 22 ppm para B, 7 ppm para Cu, 45 ppm para Fe, 20 ppm para Mn e 38 pm para $\mathrm{Zn}$.

Dechen e Hag (1981) citados por HAAG et alii

(1981) realizaram um trabalho com a finalidade de estudar a composição química de algumas espëcies arbóreas nativas da Ama zônia e coletaram amostras de folhas de plantas vegetando em condições de solo sem apresentarem sintomas visuais de desnu$\operatorname{trição.~}$

Os resultados alcançados mostraram os seguintes teores foliares para as espécies: "Cumaru" (Dipteryx odorata) - 1,49\% de N; $0,04 \%$ de P; $0,50 \%$ de K; $0,16 \%$ de Ca; $0,22 \%$ de Mg; $0,11 \%$ de S; 30 ppm de B; 5 ppm de Cu; 23 ppm de $\mathrm{Fe} ; 77 \mathrm{ppm}$ de $\mathrm{Mn}$ e $24 \mathrm{ppm}$ de $\mathrm{Zn}$. "Andiroba" (Carapa guianensis) - 1,65\% de N; 0,05\% de P;0,41\% de K; 0,39\% de Ca;0,25\% de Mg;0,13\% de $\mathrm{S} ; 52$ ppm de B; 7 ppm de Cu; 38 ppm de Fe; 11 ppm de Mn e 18 ppm de Zn; "Angelim rajado" (Pithecolobium racemosum) - 2,53\% de $\mathrm{N} ; 0,05$ de $\mathrm{P} ; 0,48 \%$ de $\mathrm{K} ; 0,20 \%$ de Ca; $0,16 \%$ de $\mathrm{Mg} ; 0,13 \%$ de S; 27 ppm de B; 4 ppm de Cu; 25 ppm de Fe; 24 ppm de Mn e 11 ppm de Zn. "Cardeiro" (Scleronema micronthum) - 2,59\% de N; $0,08 \%$ de P; $0,56 \%$ de K; $0,27 \%$ de Ca; 0,28\% de Mg;0,09\% de S; 21 ppm de B; 5 ppm de Cu; 45 ppm de Fe; 44 ppm de Mn e 17 ppm de $\mathrm{Zn}$. Os autores observaram que as espécies nativas apresentam concentrações de macronutrientes bem inferiores aos : observados em Gmelina arborea cultivada em presença de solução nutritiva completa (HAAG et alii, 1981). 
Para mostrar as variações de nutrientes ao lon go do caule, ZEN et alii (1981) coletaram três ärvores pertencentes a um talhão homogêneo de Eucalyptus saligna com 11 anos de idade, plantado em Piracicaba - Estado de São Paulo. o método de amostragem constituiu-se em seccionar o caule de 2 em 2 metros a partir da base até o äpice, retirando um disco de cada seç̧ão, os quais foram postos para secar, e posteriormente moidos e analisados quanto ao teor de macronutrientes na casca e no lenho. Os resultados mostraram que as principais diferenças entre a concentração de nutrientes nos caules das ärvores, foram observadas na casca, sendo que no ienho, apenas o P mostrou variação significativa, sugerindo a necessidade de se ampliar a amostragem quando se trata de estimar a concentração média de elementos químicos na biomassa dos caules de um povoamento florestal. Outrofato observado, foi que a concentração de nutrientes tende a ser mais elevada na parte superior do caule, sendo que este fenômeno foi mais evidente no lenho do que na casca.

Em face da ampla variação no tamanho das ärvores da mesma idade plantadas em povoamentos puros zĀKIA et ali (1983) desenvolveram um trabalho com o objetivo de estudar a va riação na concentração dos nutrientes nas copas das árvores de um talhão de Eucalyptus saligna, com 8 anos de idade, no espaçamento de $3 \times 2 \mathrm{~m}$, comparando-o com a concentração de nu trientes nas folhas das ärvores de um povoamento energéticode Eucalyptus grandis no espaçamento de $1,0 \times 1,5 \mathrm{~m}$ e cortado 
com 2,5 anos de idade. Os resultados mostraram as seguintes concentrações de nutrientes nos componentes da copa, em função das diferentes classes de altura para Eucalyptus saligna: $\underline{7,5 \text { a } 12,5 \mathrm{~m} \text { de altura }}-0,29 \%$ de $\mathrm{N} ; 0,04 \%$ de P; $0,22 \%$ de K;

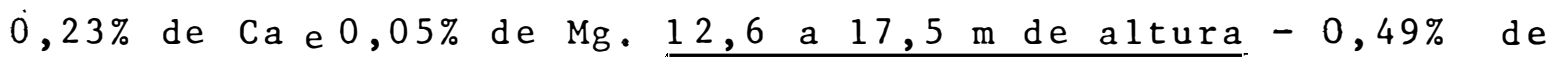
$\mathrm{N} ; 0,06 \%$ de P; $0,26 \%$ de K; $0,26 \%$ de Ca e $0,07 \%$ de $\mathrm{Mg}, \underline{17,6 \quad \text { a }}$ $\underline{22,5 \mathrm{~m} \text { de altura }}-0,58 \%$ de $\mathbb{N} ; 0,07 \%$ de P; $0,35 \%$ de $\mathrm{K} ; 0,35 \%$ de Ca e 0,10\% de Mg. 22,6 a 27,5 m de altura. $-0,67 \%$ de N; $0,08 \%$ de P; $0,42 \%$ de K; $0,43 \%$ de Cae $0,14 \%$ de Mg. A concentração de nutrientes. nas folhas de Eucalyptus grandis em função das classes de altura foram: 6,0 a $8,5 \mathrm{~m}$ de altura $-1,84 \%$ de $N ; 0,11 \%$ de $P ; 0,86 \%$ de $K ; 0,87 \%$ de Cae $0,25 \%$ de $\mathrm{Mg}, \underline{8,6 \quad a}$ $\underline{11,0 \mathrm{~m} \text { de altura }}-1,93 \%$ de $\mathrm{N} ; 0,10 \%$ de $\mathrm{P} ; 0,79 \%$ de $\mathrm{K} ; 0,59 \%$ de Ca e $0,21 \%$ de $\mathrm{Mg} \cdot \underline{11,1 \text { a } 13,5 \text { m de altura }}-1,81 \%$ de Na $0,10 \%$ de P; $0,58 \%$ de K; $0,45 \%$ de Ca e $0,17 \%$ de $\mathrm{Mg} \cdot \underline{13,6 \text { a } 16,0 \mathrm{~m}}$ de altura-1,87\% de $N ; 0,11 \%$ de $\mathrm{P} ; 0,53 \%$ de $\mathrm{K} ; 0,46 \%$ de Ca e $0,16 \%$ de Mg. Os autores observaram que no talhão convencional de Eucalyptus saligna a concentração de nutrientes na copa cresce com a altura das árvores, enquanto que a concentração de nutrientes nas folhas do talhão de Eucalyptus grandis apresenta um comportamento inverso e que este efeito pode ser explicado pe 1 a intensa competição entre as ärvores de Eucalyptus grandis, principalmente em relação ao consumo de àgua.

Estudando a exportação de biomassa e nutrientes através da explotação dos troncos e copas de um povoamento de Eucalyptus saligna com 8 anos de idade instalado em um 
solo arenoso e de baixa fertilidade POGGIANI et alie

coletaram 50 árvores de diferentes classes de diâmetro para avaliação da concentração de nutriẹtes. Os resultados mostra ram as seguintes concentrações de nutrientes nos resíduos (fo ihas + ramos) por classes de diâmetro (DAP): $\underline{2-6,9 \text { cm }}$ $0,25 \%$ de N; $0,04 \%$ de P; $0,19 \%$ de K; $0,19 \%$ de Ca; $0,04 \%$ de Mg; 76 ppm de Fe; 5 ppm de Cu; 128 ppm de Mn e 5 ppm de Zn. 7 $\underline{11,9 \mathrm{~cm}}-0,47 \%$ de $\mathrm{N} ; 0,06 \%$ de $\mathrm{P} ; 0,27 \%$ de K; $0,28 \%$ de Ca; $0,07 \%$ de Mg; 50 ppm de Fe; 5 ppm de Cu; 194 ppm de Mn e 9 ppm de $Z_{n}: 12-16,9 \mathrm{~cm}-0,67 \%$ de $\mathrm{N} ; 0,07 \%$ de $\mathrm{P} ; 0,37 \%$ de $\mathrm{K} ; 0,39 \%$ de Ca; 0,11\% de Mg; 70 ppm de Fe; 5 ppm de Cu; 298 ppm de Mn e 9 ppm de Zn $17-24,0 \mathrm{~cm}-0,66 \%$ de $N ; 0,09 \%$ de $P ; 0,42 \%$ de $\mathrm{K} ; 0,40 \%$ de Ca; $0,15 \%$ de Mg; 69 ppm de Fe; 5 ppm de Cu; 320 ppm de $M n$ e 14 ppm de Zn. Através dos resultados obtidos observaram um aumento da concentração dos elementos nos resíduos em função dos diâmetros das ärvores. De uma maneira geral verificaram que quanto maior o diâmetro, maior é a concentração dos elementos. Entretanto relatam que este fato poderia ser explicado pela existência de manchas mais férteis de solo devido, provavelmente, ao efeito da deposição de cinzas sobre o solo por ocasião da queimada das leiras formadas antes do preparo do solo. Parece haver uma estreita correlação entre DAP, a biomassa de resíduos e a concentração de nutrientes.

Estudando a concentração de nutrientes contidos nos diferentes órgãos da planta em função da biomassa pró 
duzida SILVA (1983) desenvolveu um experimento envolvendo Eucalyptus grandis, Eucalyptus saligna, Eucalyptus propinqua, Eucalyptus dunnii e Eucalyptus robusta todos com 10 anos de idade, plantados em solos arenosos e de baixa fertilidade, em Itirapina, Estado de São Paulo. Em função dos resultados obtidos verificou que os nutrientes concentraram-se de forma de crescente nas folhas do äpice da copa, folhas da parte intermediária da copa, ramos, casca e lenho. Nas folhas de um modo geral, o Eucalyptus dunnie apresentou as maiores concentrações de $\mathrm{N}$ e $\mathrm{P}$. Os Eucalyptus dunnie e Eucalyptus robusta destacaram-se pelas altas concentrações de Mn nas folhas. Nos ra mos, o Eucalyptus dunnie apresentou a maior concentração de $\mathrm{N}$ e o Eucalyptus propinqua as mais altás concentrações de $\mathrm{P}$, $\mathrm{K}, \mathrm{Ca} \mathrm{e} \mathrm{Mg}$. Na casca, o Eucalyptus saligna mostrou a maior concentração de $\mathrm{Ca}$ e no lenho o Eucalyptus grandis apresentou as menores concentrações de $P$ e $K$. Observou também que as cor relações entre as concentrações dos diferentes elementos e o tamanho das ärvores acusaram várias tendências de acordo com as espéciés. Entretanto, relata que de uma maneira geral, ocor reu um efeito de diluição dos elementos $N$, Mg e K em funçãodo aumento do tamanho das ärvores. O Eucalyptus grandis evidenciou uma capacidade maior de translocação de $P$ do lenho para as folhas. O Eucalyptus saligna mostrou-se como uma espécie acumuladora de Ca na casca. 
2.2.2. Extração de nutrientes

Os valores apresentados pela literatura sobre extração de nutrientes em espēcies florestais são variáveis. Estas variações devem-se fundamentalmentè às condições experimentais sob as quais foi realizado o trabalho. Porém, a dis tribuição das quantidades de nutrientes na planta depende de diversos fatores, entre eles a espécie (OVINGTON e MADGWICK, 1959 ; CROW e BLANK, 1978; TARAS, 1978), idade da planta (FORREST e OVINGTON, 1970; POGGIANI et alii, 1979; SINGH, 1982), altitude e práticas de manejos silvicuiturais (MADGWICK, 1976). Daí portanto as diferenças encontradas nos trabalhos citados dos diversos autores, a seguir:

Estudando a composição do Pinus elliottii, MELo et alii (1960) obtiveram as seguintes quantidades de macronutrientes extraídos e distribuídos nas diversas partes das plantas de um povoamento com 4 anos de idade instalado em um solo da formação Corumbatai em Piracicaba: Folhas - 7,23 g de N;0,47 g de P; 2,05 g de K; 1,23 g de Cae 0,70 g de Mg. $\underline{\text { Ramos }}-0,48 \mathrm{~g}$ de $\mathrm{N} ; 0,07 \mathrm{~g}$ de $\mathrm{P} ; 0,17 \mathrm{~g}$ de K;0,01 g de Ca e $0,08 \mathrm{~g}$ de $\mathrm{Mg}$. Tronco $-2,73 \mathrm{~g}$ de $\mathrm{N} ; 0,39 \mathrm{~g}$ de P; 1,23 g de $\mathrm{K} ; 0,84 \mathrm{~g}$ de Cae $0,78 \mathrm{~g}$ de $\mathrm{Mg} \cdot \underline{\text { Raízes }}-1,80 \mathrm{~g}$ de $\mathrm{N} ; 0,18 \mathrm{~g}$ de $\mathrm{P} ; 0,64 \mathrm{~g}$ de $\mathrm{K} ; 0,43 \mathrm{~g}$ de $\mathrm{Ca}$ e $0,25 \mathrm{~g}$ de $\mathrm{Mg}$. Esses valores perfazem um total de $12,24 \mathrm{~g} / \mathrm{planta}$ de $\mathrm{N} ; 1,11 \mathrm{~g} / \mathrm{planta}$ de $\mathrm{P}$; 4,09 g/planta K; 2,51 g/planta de Ca e 1,81 g/planta de Mg. Os autores observaram que as quantidades de P, Ca e Mg extraídas 
foram muito pequenas, entretanto, consideraram que talvez fos se devido a pobreza do solo onde as plantas estavam instaladas .

HAAG et alii (1961a) analisaram plantas de Eucalyptus alba e Eucalyptus grandis provenientes de uma população de 2 anos instalada em solo de cerrado e observaramas seguintes quantidades de nutrientes extraídas em g/planta: Eucalyptus alba - 22,21 g de $\mathrm{N} ; 2,33 \mathrm{~g}$ de $\mathrm{P} ; 22,28 \mathrm{~g}$ de $\mathrm{K}$; $32,44 \mathrm{~g}$ de Ca e 7,82 g de Mg. Eucalyptus grandis - 22,80 g de $\mathrm{N} ; 2,55 \mathrm{~g}$ de P; 19,06 g de K; 33,71 g de Ca e 8,10 g de Mg. Pe los dados obtidos verificaram que as éspécies estudadas requerem grande quantidade de $N, P$ e Ca.

Com o objetivo de avaliar a contribuição d o Pinus taeda e Eucalyptus citriodora na formação da quantidade de nutrientes na manta orgânica do solo HAAG et alii coletaram amostras de dois povoamentos com 20 e 24 anos respectivamente, instalados em um solo classificado como Podzólico Vermelho-Amarelo, variação Laras: no município de Piracica ba, Estado de São Paulo. Em cada povoamentoforam colhidas amostras de acículas e folhas para a determinação dos teores e quantidade de nutrientes, amostras da manta orgânica e de so10. Os resultados mostraram que o Pinus taeda contribuiu com $13,95 \mathrm{t} / \mathrm{ha}$ e o Eucalyptus citriodora com $19,98 \mathrm{t} / \mathrm{ha}$ na quant dade da manta orgânica do solo. Por outro lado, os autores observaram que a quantidade de nutrientes existentes em 100 acículas de Pinus taeda foram: $91,71 \mathrm{mg}$ de $\mathrm{N} ; 6,24 \mathrm{mg}$ de P: 
$35,30 \mathrm{mg}$ de $\mathrm{K} ; 43,24 \mathrm{mg}$ de Ca; 14,40 mg de Mg; 10,78 mg de s; $0,27 \mathrm{mg}$ de $\mathrm{B} ; 0,03 \mathrm{mg}$ de Cu; 1,57 $\mathrm{mg}$ de Fe; 4,96 mg de $\mathrm{Mn}$ e $0,22 \mathrm{mg}$ de $\mathrm{Zn}$ enquanto que as quantidades contidas em 100 foThas de Eucalyptus citriodora foram: $1.038,94 \mathrm{mg}$ de $\mathrm{N} ; 73,04$ mg de P; 926,44 mg de K; 577,72 mg de Ca; 99,02 mg de Mg; $90,92 \mathrm{mg}$ de S; 3,85 mg de B; 0,58 mg de Cu; 10,88 mg de Fe; $57,26 \mathrm{mg}$ de $\mathrm{Mn} 2,54 \mathrm{mg}$ de $\mathrm{Zn}$. Concluíram que o Eucalyptus citriodora contribuiu em maior quantidade de nutrientes para a formação da manta orgânica, em face do seu maior volume de nutriente contido nas folhas.

BALLONI (1979) fez uma estimativa da quantidade de nutrientes contidos no caule e nos resíduos de uma floresta de Eucalyptus grandis com 4 anos de idade obtendo os se guintes resultados: Caule $-60 \mathrm{~kg} / \mathrm{ha}$ de $\mathrm{N} ; 6 \mathrm{~kg} / \mathrm{ha}$ de $\mathrm{P}$ e 16 $\mathrm{kg} / \mathrm{ha}$ de K. Residuos - $90 \mathrm{~kg} / \mathrm{ha}$ de $\mathrm{N} ; 10 \mathrm{~kg} / \mathrm{ha}$ de $\mathrm{Pe} 39 \mathrm{~kg} / \mathrm{ha}$ de K. Concluiu que é evidente a importância dos resíduos de ex ploração para o desenvolvimento da rotação seguinte.

Estudando a extração e exportação de macronu trientes pelo Eucalyptus grandis em função da idade BELLOTE (1979) coletou amostras de folhas, ramos ativos e inativos, ponta, meio e base do caule de plantas com 1 a 7 anos de idade em povoamentos instalados em um solo do tipo Latossolo ver melho-Amarelo barro arenoso, no Horto Florestal de Mogi-Guaçu, em São Paulo. Os resultados obtidos mostraram que as plantas acumularam o máximo de matéria seca aos 6,7 anos; a altura ma xima ocorreu aos 7 anos de idade e diâmetro (DAP) máximo após 
7 anos de idade $(7,3 \mathrm{~cm})$; as maiores acumulações de $\mathrm{N}, \mathrm{P}, \mathrm{K}$, $\mathrm{Ca}, \mathrm{Mg}$ e $\mathrm{S}$ nas plantas ocorreram nas folhas; as plantas atingiram a mäxima quantidade de nutrientes nas seguintes idades (anos): $\mathrm{P}=6,1 ; \mathrm{N}, \mathrm{K}, \mathrm{Ca}, \mathrm{Mg}$ e $\mathrm{S}=7$; os nutrientes mais extraídos e exportados em ordem decrescente foram: $\mathrm{Ca}>\mathrm{N}>\mathrm{K}$. $>\mathrm{S}>\mathrm{Mg}>\mathrm{P}$; a quantidade de macronutrientes extraídos por planta aos 7 anos de idade foram: $386,92 \mathrm{~g} / \mathrm{planta}$ de Ca; 260,14 g/planta de N; 117,43 g/planta de K; 106,11 g/plantade $\mathrm{S} ; 85,47 \mathrm{~g} / \mathrm{planta} \mathrm{de} \mathrm{S}$ e $20,18 \mathrm{~g} / \mathrm{planta} \mathrm{de} \mathrm{P}$; mais de $98 \%$ do P acumularam até 6 anos de idade e para os demais nutrientes as quantidades acumuladas aumentaram com o envelhecimento das plantas; o Mg foi o nutriente mais exportado em porcentagemdo total extraído pelas plantas, vindo em ordem decrescente: P > $\mathrm{Ca}>\mathrm{K}=\mathrm{S}>\mathrm{N}$.

\section{Com relação aos micronutrientes BELLOTE} obedeceu a mesma metodologia do trabalho citado anteriormente e concluiu que as plantas atingiram a máxima quantidade de nu trientes nas seguintes idades (anos): $\mathrm{Zn}=5,4 ; \mathrm{Mn}=6,3 ; \mathrm{B}$, $\mathrm{Cu}, \mathrm{Fe}$ e Mo $=7,0$; os nutrientes mais extraídos e exportados, em ordem decrescente, foram: $\mathrm{Mn}>\mathrm{Fe}>\mathrm{B}>\mathrm{Cu}>\mathrm{Zn}>\mathrm{Mo}$; a quantidade de micronutrientes extraídos por planta aos 7 anos de idade foram: $12135,13 \mathrm{mg} / \mathrm{planta}$ de Mn; 2618,23 mg/plantade Fe; $884,16 \mathrm{mg} / \mathrm{planta} \mathrm{de} B ; 538,57 \mathrm{mg} / \mathrm{planta} \mathrm{de} \mathrm{Cu} ; 258,92 \mathrm{mg} /$ planta de Zne $6,78 \mathrm{mg} / \mathrm{planta}$ de Mo; o Mo foi o micronutriente mais exportado do total extraído pelas plantas; mais de $98 \%$ do Mn acumulou até 6 anos de idade, $99,4 \%$ do $\mathrm{Zn}$ aos 5 anos 
e para os demais nutrientes as quantidades acumuladas aumentaram com o envelhecimento das plantas.

Fazendo uma estimativa da remoção de nutrientes e biomassa de um povoamento florestal poGGIANI et ali (1980) coletaram vinte e quatro ärvores íncluindo todas classes de diâmetro de um talhão de Eucalyptus grandis com 2,5 anos de idade ( 5.333 ärvores/ha). As ärvores coletadas fo ram divididas em folhas, ramos e caule para determinação da biomassa e nutrientes contidos nas diferentes partes da planta. Os resultados mostraram que num talhão de Eucalyptus gran dis aos 2,5 anos de idade foram produzidas as seguintesquantida des de nutrientes em kg/ha: Folhas. $-140,9 \mathrm{~kg}$ de $\mathrm{N} ; 8,4$ $\mathrm{kg}$ de $\mathrm{P} ; 49,5 \mathrm{~kg}$ de $\mathrm{K} ; 44,9 \mathrm{~kg} \mathrm{de} \mathrm{Ca} ; 15,2 \mathrm{~kg}$ de $\mathrm{Mg} ; 2,2 \mathrm{~kg}$ de $\mathrm{Fe} ; 0,03 \mathrm{~kg}$ de $\mathrm{Cu} ; 7,2 \mathrm{~kg}$ de $\mathrm{Mn}$ e 0,09 kg de Zn. Ramos. $26,6 \mathrm{~kg}$ de N; $2,3 \mathrm{~kg}$ de P; $21,4 \mathrm{~kg}$ de $\mathrm{K} ; 15,0 \mathrm{~kg}$ de Ca; 2,3kg de $\mathrm{Mg} ; 0,5 \mathrm{~kg}$ de $\mathrm{Fe} ; 0,02 \mathrm{~kg}$ de Cu; 2,3 kg de Mn e 0,03 kg de Zn. Caule $-108,4 \mathrm{~kg}$ de $\mathrm{N} ; 17,3 \mathrm{~kg}$ de $\mathrm{P} ; 166,3 \mathrm{~kg}$ de K; 65,1 $\mathrm{kg}$ de Ca; 15,2 kg de Mg; $2,8 \mathrm{~kg}$ de Fe;0,11 kg de Cu; 13,3 kg de $M n$ e $0,40 \mathrm{~kg}$ de $Z n$. Observaram que $9 \%$ da biomassa está con tida nas folhas, $7 \%$ nos ramos e $83 \%$ no caule, entretanto $37 \%$ dos nutrientes estão contidos nas folhas, $10 \%$ nos ramos e $53 \%$ nos caules. Os autores concluiram que em solos de cerrado com baixa fertilidade, principalmente em $P$ e K, seria recomendävel que se evitasse a remoção de folhas, ramos e cascas do local explorado.

A distribuição da fitomassa e nutrientes em ta 
Ihão de Pinus oocarpa com 8 anos de idade foi estudada

por

CASTRO et alii (1980). Observaram que a biomassa está distribuída numa proporção de $5,7 \%$ nas acículas, $9,9 \%$ nos ramos, $15,2 \%$ na casca e $69,2 \%$ na madeira do tronco, correspondendo a $5.933 \mathrm{~kg} / \mathrm{ha}, 10.089 \mathrm{~kg} / \mathrm{ha}, 15.485 \mathrm{~kg} / \mathrm{ha}$ e $70.552 \mathrm{~kg} / \mathrm{ha}$, respectivamente; a quantidade de macronutrientes contidos na bio massa arbórea nos diferentes órgãos da planta estão assim dis tribuidas num hectare $(2.313$ plantas $):$ Aciculas - $92,8 . \mathrm{kg}$ de $\mathrm{N} ; 7,0 \mathrm{~kg}$ de $\mathrm{P} ; 31,5 \mathrm{~kg}$ de $\mathrm{K} ; 10,7 \mathrm{~kg}$ de $\mathrm{Ca} ; 5,1 \mathrm{~kg}$ de $\mathrm{Mg} ; 1,4$ $\mathrm{kg}$ de Fe; $1,3 \mathrm{~kg}$ de Mne 0,1 kg de Zn. Ramos $-37,3 \mathrm{~kg}$ de N; $2,5 \mathrm{~kg}$ de $\mathrm{P} ; 20,7 \mathrm{~kg}$ de $\mathrm{K} ; 11,7 \mathrm{~kg}$ de $\mathrm{Ca} ; 4,5 \mathrm{~kg}$ de $\mathrm{Mg} ; 0,7$ $\mathrm{kg}$ de Fe; 1,0 kg de Mne 0,1 kg de Zn. Casca $-46,6 \mathrm{~kg}$ de N; $2,5 \mathrm{~kg}$ de P; 18,1 kg de K; 18,9 kg de Ca; 3,3 kg de $\mathrm{Mg} ; \quad 1,1$ $\mathrm{kg}$ de Fe; $0,5 \mathrm{~kg}$ de Mne $0,1 \mathrm{~kg}$ de $\mathrm{Zn}$. Madeira do tronco $93,9 \mathrm{~kg}$ de $\mathrm{N} ; 8,5 \mathrm{~kg}$ de $\mathrm{P} ; 63,5 \mathrm{~kg}$ de $\mathrm{K} ; 36,0 \mathrm{~kg}$ de Ca; 12,0 $\mathrm{kg}$ de $\mathrm{Mg} ; 1,7 \mathrm{~kg}$ de Fe; $3,9 \mathrm{~kg}$ de $M n^{2} 0,5 \mathrm{~kg}$ de $\mathrm{Zn}$. A absorção de nutrientes seguiu a seguinte ordem decrescente: $N>K$ $>\mathrm{Ca}>\mathrm{Mg}>\mathrm{P}>\mathrm{Mn}>\mathrm{Fe}>\mathrm{Zn}$ correspondendo a um total de 270,6 $\mathrm{kg} / \mathrm{ha}$ de $\mathrm{N} ; 133,8 \mathrm{~kg} / \mathrm{ha} \mathrm{de} \mathrm{K} ; 77,3 \mathrm{~kg} / \mathrm{ha}$ de Ca; 24,9 kg/ha de $\mathrm{Mg} ; 18,5 \mathrm{~kg} / \mathrm{ha}$ de $\mathrm{P} ; 6,7 \mathrm{~kg} / \mathrm{ha}$ de $\mathrm{Mn} ; 4,9 \mathrm{~kg} / \mathrm{ha}$ de $\mathrm{Fe}$ e $0,8 \mathrm{~kg}$ de $Z n$, respectivamente; a distribuị̧ão dos nutrientes das plan tas não é equitativa à da matéria seca, sendo suas concentrações mais elevadas nas acículas, em seguida nos ramos, :casca e madeira do fuste.

SILVA (1983) fez.um. trabalho onde um dos objetivos foi verificar o conteúdo de nutrientes no lenho e cas 
ca da planta em função da biomassa produzida. Os resultados mostram o conteúdo de nutrientes no lenho e casca em kg/ha, respectivamente, nas diferentes espécies estudadas: Eucalyptus grandis - 128,2 e $67,6 \mathrm{~kg}$ de $\mathrm{N} ; 3,7$ e $6,2 \mathrm{~kg}$ de $P ; 97,8$ e $70,0 \mathrm{~kg} d e \mathrm{~K} ; 264,5$ e $71,3 \mathrm{~kg}$ de Ca e 76,9 e 22,6 de Mg. Eucalyptus saligna - 202,4 e $57,8 \mathrm{~kg}$ de $\mathrm{N} ; 6,4$ e'4,0 kg … de P; 121,5 e $51,8 \mathrm{~kg}$ de K; 317,2 e $102,4 \mathrm{~kg}$ de Ca e 72,5 e 24,0 kg de $\mathrm{Mg}$. Eucalyptus propinqua - 102,8 e $52,7 \mathrm{~kg}$ de $\mathrm{N} ; 8,0$ e 4,3 de P; 111,4 e $39,2 \mathrm{~kg}$ de K; 123,4 e 30,3 kg de Ca e 19,7 $36,4 \mathrm{~kg}$ de $\mathrm{Mg}$. Eucalyptus dunnii - 95,5 e 42,0 kg de $\mathrm{N} ; 6,7$ e $3,6 \mathrm{~kg}$ de P; 199,4 e 61,1 kg de K; 265,0 e 69,9 kg de Cae 41,4 e $22,6 \mathrm{~kg}$ de $\mathrm{Mg}$. Eucalyptus rabusta - 185,5 e 37,4 kg de $\mathrm{N}$; 10,3 e 4,7 kg de P; 135,0 e 43,7 kg de K; 210,1 e 52,8 kg de Ca e 29,3 e $33,7 \mathrm{~kg}$ de $\mathrm{Mg}$. Analisando o conteūdo de nutrientes no lenho o autor observou que o Eucalyptus dunnie é o que menos acumula $\mathrm{N}$ enquanto o Eucalyptus grandis é o que tem maior produtividade com menor acúmulo de $P$ e $K$ e o Eucalyptus robus ta é o que mais acumula P. Na casca verificou que o talhão de Eucalyptus grandis é o que acumula mais $N, P$ e $K$ e o que tem menor acúmulo de $\mathrm{Mg}$. Os demais elementos são acumulados em menores quantidades nos talhões de Eucalyptus robusta (N); Eucalyptus dunnii ( $P$ ) e Eucalyptus propinqua ( $\mathrm{K}$ e $\mathrm{Ca}$ ).

POGGIANI et alii (1983) quantificaram a biomas sa produzida pelos residuos florestais da copa (ramos e fo1has) de um talhão de Eucalyptus saligna com 8 anos de idade, plantado em solo arenoso e de baixa fertilidade no interiorde 
São Paulo. Para avaliação do conteüdo de nutrientes foram ana lisadas 50 ärvores de diferentes classes de diâmetro, onde fo ram retiradas duas amostras dos resíduos da copa bem homogeneizada e duas do fuste englobando lenho.e casca de maneira proporcional. Os resultados da anälise mostraram o conteūdo de nutrientes na biomassa arbörea em kg/ha: Copa_ (fo1has + ramos $)-83,3 \mathrm{~kg}$ de $\mathrm{N} ; 10,6 \mathrm{~kg}$ de $\mathrm{P} ; 50,4 \mathrm{~kg} \mathrm{de} \mathrm{K} ; 51,3$ $\mathrm{kg}$ de $\mathrm{Ca} ; 14,9 \mathrm{~kg}$ de $\mathrm{Mg} ; 1,0 \mathrm{~kg}$ de Fe; $0,08 \mathrm{~kg}$ de Cu; 3,8 kg de $\mathrm{Mn}$ e $0,14 \mathrm{~kg}$ de $\mathrm{Zn}$. Fuste $(1$ enho + casca) - 134,9 kg de N; $17,9 \mathrm{~kg}$ de P; 125,9 kg de K; 134,9 kg de Ca; 27,0 kg de $\mathrm{Mg}$; $6,7 \mathrm{~kg}$ de Fe; $0,17 \mathrm{~kg}$ de $\mathrm{Cu} ; 7,3 \mathrm{~kg}$ de $\mathrm{Mn}$ e 0,44 kg de Zn. Ob servaram que os resíduos acumulam grande parte dos nutrientes contidos na biomassa do talhão com 1200 ärvores/ha nas seguin tes proporções: $38 \%$ de N; $37 \%$ de P; $28 \%$ de K; $27,6 \%$ de Ca e $35 \%$ de Mg. Por outro lado, constataram que em todos os casos a participação da copa no valor total de nutrientes $\vec{e}$ muito elevada, e que em face do preço atual dos adubos é agora possível pesar as vantagens da exportação dos resíduos para fins energéticos. Os autores aconselham incrementar as pesquisas para seleção de espécies e clones com uma eficiência mais elevada na utilização dos nutrientes com o objetivo de se aumentar a produção de biomassa com uma menor exportação de nutrientes do sítio. 
2.2.3. Sintomas de deficiências nutricionais

Segundo FRAZÃo (1983), os elementos minerais exercem funções muito importantes na planta, e muitas vezes específicas nos processos fisiológicos. As carências minerais nas plantas provocam distürbios no seu metabolismo, os quais freqüentemente alteram os aspectos morfológicos e anatômicos, evidenciando muitas dessas deficiências. Porēm, em virtude das interações que ocorrem nos processos torna-se difícil pre cisar a maneira pela qual as deficiências provocam os efei tos observados, haja vista que o amarélecimento ou clorosedas folhas que são sintomas comumente verificados, podem ser causados por outros fatores como excesso de nutrientes, deficiên cia hídrica, ataque de pragas elou doenças, são alguns dos mo tivos de clorose que podem ser confundidos com carência mineral (KRAMER e KOSLOWSKI, 1960 e BALLARD, 1979).

Uma das principais restrições para o uso desse artificio, visando à correção através da adubação, ë o fato do sintoma aparecer somente após a planta sofrer uma redução do ritmo de crescimento (BALLARD, 1979). Entretanto, apesar das limitações mencionadas, não hã dūvida de que os sintomas visuais são a maneira mais prätica e räpida de acordo com TAMM (1964) para se detectar uma deficiência nutricional, desdeque o técnico seja habilidaso e experiente e possa contar sempre que possivel com a ajuda de uma anālise foliar. 
2.2.3.1. Deficiência de nitrogênio

o nitrogênio é um elemento de extrema importân cia, uma vez que em quantidade é o quarto nutriente mais abun dante nas plantas, vindo após o carbono, o hidrogênio e o oxi gênio. De acordo com EPSTEIN (1975), o estudo do papel do nitrogênio quase se confunde com a própria bioquímica, pois, além de ser constituinte de compostos vitais e participar na formação da clorofila, é essencial para a planta nas diversas fases de desenvolvimento. A carência deste elemento, entre ou tros fatores provoca uma clorose nas folhas reduzindo assim sua capacidade fotossintética, bem como apresenta uma diminui ção no ritmo de crescimento das plantas e em casos extremospo de até causar a paralisação.

Os sintomas iniciais de carência de nitrogênio em Eucaluptus urophylla caracterizam-se, segundo Rocha FILHo et alii (1978b), pelo aparecimento nas folhas inferiores de uma clorose generalizada na área do limbo. Associada a essa cloro se ou amarelecimento, observou-se uma diminuição do crescimen to da planta, quando comparada com a testemunha (cultivada em solução completa). Posteriormente, a clorose caminhava no sen tido das folhas mais novas e com a progressão da sintomatologia todas as folhas apresentavam sintomas de deficiência. As folhas mostravam no limbo uma coloração verde-limão, enquanto que as nervuras tinham uma cor levemente avermelhada. HAAG et alii (1961b) trabalhando com Eucalyptus alba observou que neste estágio de carência apareceram também pequenas manchas aver 
melhadas no limbo e com o progredir da deficiência atingia a folha inteira. Outros sintomas descritos por RochA FILHO et alie (1978b) foi o crescimento reduzido do caule, dando à planta um porte baixo, internódios curtos, poucas folhas, sem rami ficações ou brotações laterais. Os sintomas obtidos estão con cordantes com os descritos por WILL (1961a) trabalhando com E. botryoides, E. salignae E. pilularis; por HAAG et alii (1961b), com E. alba; por KAUL et alii (1966) com Eucalipto (híbrido) e por BHIMAYA e KAUL (1966) desenvolvendo trabalho com E. camaldulensis.

MALAVOLTA et alie (1970) obtiveram e descreveram sintomas de deficiência de nitrogênio em Pinus elliottii evidenciados primeiramente por uma clorose nas acículas mais velhas e que mais tarde com a evolução dos sintomas atingiram as mais novas. Posteriormente, nas acículas mais velhas apareceu uma coloração parda no äpice, e quando a carência se acentuou, toda a acícula se tornava avermelhada e em seguida murcha destacando-se facilmente. Outro sintoma típico é uma redução no crescimento das plantas.

As plantas de Araucaria angustifolia deficientes em nitrogênio de acordo com SIMÕES (1973) apresentaram-se pouco desenvolvidas e com clorose acentuada e generalizada. 0 amarelecimento começava pelas folhas mais velhas, tanto do caule, como dos ramos laterais. O crescimento vegetativo foi reduzido enquanto os ponteiros permaneciam - discretamente mais verdes, contrastando com a clorose restante. Com a pro- 
gressão da deficiência iniciou, pelas folhas mais velhas, um crestamento a partir do äpice progredindo para a base do limbo e atingindo a bainha, dando um aspecto de morta à folha.

Os primeiros sintomas de deficiência de nitrogênio em Gmelina arborea, reportados por HAAG et alii (1981), se manifestaram nas folhas mais velhas que perderam a sua coloração característica sendo substituída por uma coloraçãover de-clara tomando conta de toda a ärea foliar. Com a evolução da deficiência estes sintomas se transferiram para as folhas medianas, iniciando nas mais velhas um processo de secamento. A planta também diminuiu seu ritmo de crescimento.

2.2.3.2. Deficiência de fósforo
o fósforo nos solos do trópico úmido é um dos elementos mais carentes, fazendo com que os níveis de pro dutividade alcançados nos diversos cultivos sofram limitações. Desempenha na planta um papel relevante em reações bioquímicas no metabolismo dos carboidratos, particularmente na respiração, divisão celular e desenvolvimento meristemático.A maioria das plantas carentes em fósforo tem seu sistema radicular pouco desenvolvido e apresenta distúrbios de crescimento. As folhas e caules de plantas deficientes geralmente são pequenas e têm cor avermelhada, marrom ou bronzeada.

Em Eucalyptus urophylla, ROCHA FILHO et alii (1978b) observaram que os sintomas de deficiência de fósforo iniciaram-se pelo surgimento de pontos cloróticos no limbodas 
folhas inferiores que com a progressão dos sintomas tornavamse avermelhadas crescendo em tamanho formando manchas maiores até alcançar a folha inteira. Posteriormente, essas manchas necrosavam-se, secavame em seguida ocorria a queda da folha. Quando comparadas com as plantas testemunhas, as deficientes apresentavam um menor porte vegetativo. A sintomatolo gia descrita está de acordo com as obtidas por HAAG et ali (1961b), WILL (1961a), BHIMAYA e KAUL (1966) e KAUL et ali (1966).

MALAVOLTA et alie (1970) relatam que em Pinus elliottil os sintomas de carência de fósforo aparecem em primeiro lugar nas acículas mais velhas com um leve amarelecimen to do ápice progredindo em seguida para as acículas mais novas. Com o avanço da deficiência essa clorose passa para uma cor marrom, e finalmente toda acícula fica parda.

A carência de fósforo em Araucaria angustifolia caracterizou-se por um desequilíbrio nutricional generalizado. resultando em drāstica redução no crescimento das plantas quan do comparadas com as nutridas com solução nutritiva. SIMÕES (1973) verificou que apesar de pouco desenvolvidas, as folhas novas mantinham uma coloração verde. A clorose começou também pelas folhas mais velhas, partindo do ápice para base, passando posteriormente para uma coloração parda escura e ter minando com o secamento e morte dos ramos laterais; enquanto o caule continuava vivo. Houve um pequeno desenvolvimento da 
gema terminal e surgiu indícios de brotação lateral à altura do colo da planta.

As plantas de Gmelina arborea carentes de fósforo não apresentaram redução no ritmo de crescimento quando comparadas com as plantas sadias relatam HAAG et alii (1981). Os sintomas de deficiência iniciaram-se nas folhas mais novas caracterizadas por uma coloração verde intensa em confronto com as folhas de mesma idade das plantas sadias. As folhas ve 1has perderam a cor verde, substituída por uma coloração verde-clara associada ao aparecimento de áreas necróticas entre as nervuras, da margem das folhas até a nervura. principal. Com a evolução da carência as áreas necróticas secavam e as folhas caiam.

2.2.3.3. Deficiência de potássio

Diferente dos outros macronutrientes e apesar de ser um elemento vital para a planta, a natureza do papel do potássio em qualquer processo específico, ainda não é totalmente esclarecida. Entretanto, segundo SHORROCKS (1964) hä evidências de que o potássio ocupa posição central no metabolismo da planta e está presente em grandes quantidades no tecido meristemático onde esteja ocorrendo crescimento acelerado. O potássio é um elemento altamente móvel na planta onde é redistribuído das folhas mais velhas para os órgãos novos de crescimento e como conseqüência,os sintomas de carência são encontrados nas folhas mais juelhas e se caracterizam por uma 
clorose marginal e um mosqueamento amarelo das margens e algumas vezes do ápice das folhas, seguido de necrose nessas àreas.

ROCHA FILHO et alie (1978b) relataram que os sintomas iniciais de carência de potássio em Eucalyptus urophilla apareceram nas folhas medianas com pontuações cloróticas na ārea do limbo, nos espaços entre as nervuras. Com a continuação dos sintomas, os pontos se uniam formando faixas cloróticas, que se localizavam nos bordos e ápice das folhas. Posteriormente, as manchas se tornavam necróticas espalhandose e tomando toda a ārea foliar. As folhas inferiores, nessa fase, mostravam também algumas pontuações cloróticas. .. Embora com algum desenvolvimento vegetativo, o caule apresentava menor porte quando comparado ao da planta testemunha. Esses sin tomas são concordantes com os descritos por KAUL et alii (1966) trabalhando com Eucalipto (híbrido).

A deficiência de potássio em Pinus elliottii produziu sintomas característicos, segundo o observado por MA LAVOLTA et alie (1970). Inicialmente, as acículas mais velhas apresentaram um amarelecimento nas extremidades, as quais num estägio mais avançado se tornaram de coloração parda e finalmente necrosadas:

0 aspecto geral das plantas de Araucaria angus tibolia carentes em potássio apresentaram-se pouco diferente do normal SIMÕES (1973). O crescimento da planta teve ritmo diminuido, resultando internódios curtos. Por outro lado, os 
ramos laterais superiores mostravam-se dispostos em ângulos fechados, enquanto os inferiores, em ângulos abertos, com ramificações secundárias pouco freqüentes. Além do tamanho reduzido, as folhas mais velhas apresentavam clorose nas extremidades, chegando a cor parda no äpice. Na base'do caule surgiram folhas completamente pardas, porém esparsas.

o crescimento das plantas de Gmelina arborea não foi prejudicado pela carência de potássio conforme relatam HAAG et alii (1981), porēm o nümero de folhas era bem menor, assim como o diâmetro do caule quando em confronto com as plantas sadias. Observaram uma superbrotação de folhas pe quenas na parte inferior da planta. Os primeiros sintomas sur giram nas folhas intermediärias e não nas mais velhas, e consistiram de uma leve clorose marginal caminhando para a nervu ra principal das folhas. Com o transcorrer da falta do nutriente ocorreu o secamento dos vértices das folhas. Neste es tágio as folhas logo acima mostravam os sintomas iniciais. Pa ralelamente a estes sintomas as plantas mostravam um aspecto de murchamento.

\subsubsection{Deficiência de câlcio}

Como catiónio principal da lamela média da pa rede celular na forma de pectato, o cálcio tem importante relação com a resistência mecânica dos tecidos, sendo indispensável para o funcionamento dos meristemas e desenvolvimentodo sistema radicular (CLELAND, 1960; RASMUSSEN, 1967). Mesmo sob 
condições de deficiência, o cālcio não é prontamente redistri buido, pois é relativamente imóvel no interior da planta.

Os sintomas de carência de cálcio causam prejuízos nas regiōes meristemäticas como nas folhas localizadas nas extremidades dos ramos e nas pontas das raízes. Uma clorose desenvolveu-se no ápice das folhas, que logo se transmite pelas margens, porém penetra gradualmente, nos tecidos sadios.

HAAG et alii (1961b) trabalhando com Eucalyptus alba observaram que sintomas de deficiência de cālcio eram caracterizados por plantas mal desenvolvidas, com aparecimento de manchas de coloração avermelhada ao longo do limbo das folhas mais velhas ou situadas na base dos ramos. Com a conti nuação da deficiência, o limbo mostrava-se clorótico e as man chas se tornavam necróticas.

Os sintomas iniciais de carência de cálcio emplantas de Pinus elliottii foram relatados por MALAVOLTA et alii com aparecimento de clorose das acículas começando pela base. Posteriormente as acículas inteiras se mostravam verde-amareladas com as extremidades avermelhadas. Em seguida, perdiam a turgidez ficando curvas e murchavam até caírem. Outro sintoma apresentado era a morte da gema terminal.

Os sintomas de deficiência de cālcio em Arauca ria angustifolia se manifestaram tardiamente. As plantas mostravam um aspecto quase normal, entretanto com leve clorose nas folhas, acentuando-se naquelas localizadas no terço infe- 
rior dos ramos. As ramificações e o comprimento dos internödios eram normais. As folhas mais velhas, da base do caule, apresentavam manchas de coloração parda em diferentes pontos do limbo foliar, ou às vezes completamente pardas

( S IMÕES , $1973)$.

Diferente da maioria das espécies conhecidas,os sintomas de carência de cálcio em Gmelina arborea começaram pelas folhas mais velhas e intermediárias com um amarelecimen to nítido no ápice das folhas enquanto o resto da área foliar permanecia verde. Relatam ainda HAAG et alii (1981) que em se guida as folhas mais velhas iam perdendo a coloração verde ficando com uma cor verde-clara até ocorrer a queda das mesmas, entretanto não houve morte da gema apical.

2.2.3.5. Deficiência de magnésio

0 magnésio exerce um papel de fundamental importância na fotossíntese, em virtude de ser um constituinteda molécula da clorofila. Na ausência do elemento a síntese deste pigmento é reduzida, com conseqüente diminuição do processo fotossintético. O magnésio também se envolve em muitos sis temas enzimáticos, atuando como ativador específico de numerosas enzimas, sempre associadas aos compostos de fósforo, for necedores de energia, funcionando como veículo para este elemento.

Os sintomas de deficiência surgem inicialmente nas folhas velhas e em seguida nas folhas novas à medida que 
a carência evolui, e são caracterizados por manchas cloröticas entre as nervuras em virtude do desaparecimento da clorofila.

Os sintomas de deficiência de magnésio

e m Eucalyptus urophylla foram amplamente descritos por ROCHA FILHO et alie (1978b). Constataram que nas folhas inferiores e medianas os sintomas iniciaram-se através de uma pequena clorose internerval do limbo, que rapidamente evoluiu no sentido da nervura principal. Com a evolução dos sintomas a parte clorötica secava, porém o restante da folha ficava verde. Quan do os sintomas chegavam as folhas superiores, as inferiores a presentavam manchas avermelhadas nas regiões internervais do limbo, formando, na maioria das folhas, duas faixas paralelas uma de cada lado da nervura principal. Visualmente o caule não mostrou nenhum sintoma de carência, embora, quando comparado com a planta sadia, apresentasse um menor crescimento. Os sin tomas descritos estão concordantes com os obtidos por HAAG et alii (1961b), WILL (1961a), BHIMAYA e KAUL (1966) e KAUL et alii (1966).

Conforme MALAVoLTA et alie (1974), os sintomas de deficiência de magnésio em Pinus elliottie se caracterizavam por uma descoloração das acículas sendo mais intensa naquelas localizadas na parte superior da planta. Com o progres so da deficiência, as acículas adquiriam uma coloração pardoavermelhada que se estendia da extremidade para o meio da acícula, porém os sintomas mais severos se localizavam próximo à extremidade dos ramos. 
Em Araucaria angustifolia a deficiência de mag nésio apareceu através de uma coloração parda dás folhas loca lizadas nos ramos laterais, progredindo de baixo para cima na planta. Estes sintomas de acordo com SIMÕES (1973) surgiram quando as plantas já estavam bem desenvolvidas. Nas folhas, esse crestamento começava no sentido do äpice para base, enquanto que nos ramos laterais estes sintomas caminhavam da ba se para a extremidade, chegando algumas vezes a morrer inteira mente. Por outro lado, o broto terminal vegetava intensamente, produzindo internodios de comprimento normal.

o crescimento das plantas de Gmelina arborea não foi prejudicado pela ausência de magnésio conforme relatam HAAG et alii (1981). Os sintomas de carência tiveram iní cio pelas folhas mais velhas que perdiam gradualmente a coloração verde entre as nervuras acompanhada por uma cor verde-clara em todo o 1 imbo. Com a evolução da carência as āreas cloróticas entre as nervuras necrosavam-se seguida pela queda das folhas. Neste estágio as folhas intermediárias apresenta vam-se cloróticas, repetindo o mesmo aspecto observado nas fo 1has mais velhas.

\subsubsection{Deficiência de enxofre}

0 enxofre é constituinte de numerosos compostos da planta, como proteínas e aminoácidos, bem como das subs tâncias reguladoras do crescimento (tiamina, biotina e glutamina), que participam de reaçöes do oxi-redução (JORDAN e EN 
MINGER, 1958). Entre as deficiências de enxofre e nitrogênio são observadas certas semelhanças, sendo que as características comuns a ambas são o teor reduzido de clorofila e de proteína, além de um aumento de compostos solúveis de nitrogênio presentes na folha decorrentes de uma redução na síntese da proteína. Como o enxofre é pouco móvel na plan ta, os sintomas de deficiência ocorrem inicialmente nas folhas superiores, ao conträrio do nitrogênio, cuja deficiência se caracteriza por uma clorose gradual da folha inteira, cujo tamanho é reduzido.

ROCHA FILHO et alie (1978b) observaram que a deficiência de enxofre em Eucalyptus urophylla se caracteri zou por uma clorose geral das folhas superiores, as quais iam progressivamente ficando com uma coloração verde-limão, distinguindo-se das demais que mantinham uma cor verde escuro. Embora com ausência de enxofre, as plantas mostravam um bom de senvolvimento e maiores que as plantas cultivadas em solução nutritiva completa. HAAG et alie (1961b) trabalhando com Eucalyptus alba também reportaram que com a deficiência de enxo fre as folhas novas mostravam uma clorose uniforme por toda a superfície do limbo e depois se tornavam de coloração bronzea da. Entretanto, observaram que os ramos novos apresentavam coloração purpúrea.

Os sintomas de deficiência de enxofre em Pinus elliottii relatados por MALAVOLTA et alie (1974) se caracteri zavam por uma coloração verde-pálida nas acículas mais novas, 
enquanto as mals velhas apresentavam indicação de secamento. Nas bainhas das acículas apareciam uma coloração rósea, particularmente nas mais velhas.

Para SIMÕES (1973), trabalhando com Araucaria angustifolia, não foi observado praticamente sintomas eviden tes que distinguissem as plantas normais daquelas deficientes em enxofre, a não ser um amarelecimento muito discreto nas fo lhas mais novas.

o crescimento paralisado das plantas de Gmelina arborea e apresentando $1 / 3$ da altura daquelas cultiva das em solução nutritiva completa, foi uma das características observadas por HAAG et alii (1981) em plantas deficientes em enxofre. As folhas mostraram-se menores e mais delicadas do que as plantas normais. As folhas novas de tamanho reduzido, apresentavam uma coloração citrina clara, a qual se transferia com menos intensidade para as folhas médias e mais velhas. Os pecíolos mostravam uma coloração rósea, em contras te com a coloração verde das plantas sadias.

A revisão de literatura apresentada focaliza diferentes aspectos nutricionais de algumas espécies florestais, entretanto, revela que tem sido pequeno o interesse dos pesquisadores no que concorne a nutrição mineral de espécies nativas daí mostrar-se poucas informações. Com relação a espécie do presente trabalho, ou seja, Cordia goeldiana Huber, não encontrou-se nenhum estudo específico sobre o assunto. En tretanto, considerando a importân cia que a Amazônia represen- 
ta no contexto da política florestal do Brasil e do esforço desenvolvido pela Empresa Brasileira de Pesquisa Agropecuária no sentido de estabelecer naquela região um programa de pesquisa na ärea florestal com bases mais sólidas, direcionado pa ra as espécies nativas de grande potencial como por exemplo - freijó, acredita-se que num futuro bem próximo essas lacu nas poderão ser perfeitamente preenchidas. 
3. MATERIAL E METODOS

0 presente trabalho consta de dois experimentos, sendo um desenvolvido em casa de vegetação com solução nutritiva e outro em campo.

3.1. Experimento em casa de vegetação

o experimento foi conduzido no Departamento de Solos, Geologia e Fertilizantes da Escola Superior de Agricu任 tura "Luiz de Queiroz", Universidade de São Paulo, em Piracicaba, Estado de São Paulo.

Foram utilizadas sementes da espécie

Cordia goeldiana, Huber, procedentes do Campo Experimental de Belterra, município de Santarém, Estado do Parä, pertencente ao Centro de Pesquisa Agropecuāria do Trópico Úmido - CPATU.

\subsubsection{Formação das mudas}

As sementes foram semeadas em caixa de madeira 
contendo substrato de vermiculita e areia no dia $26 / 01 / 83$, ten do a emergência iniciado 30 dias após.

Aos 70 dias após a semeadura, dia 05/04/83, as mudas com a altura aproximada de $10 \mathrm{~cm}$, foram selecionadas e após as raízes terem sido lavadas com āgua destilada para eliminar os resíduos do substrato, foram transplantadas, uma por vaso, com capacidade de 10 itros, estes revestidos inter namente com saco plästico, contendo sílica moída.

As plantas inicialmente foram irrigadas com so lução nutritiva completa (SARRUGE, 1975), diluída na propor ção de 1:1 (solução nutritiva : ägua) è renovada a cada 7 dias. Com a finalidade de propiciar um crescimento mais acelerado das mudas, passoú-se a utilizar a solução nutritiva com pleta a partir de $19 / 05 / 83$, renovando-a a cada 25 a 30 dias até que as plantas atingissem uma altura de mais ou menos $50 \mathrm{~cm}$. Cerca de 284 dias $(05 / 11 / 84)$ apōs a semeadura observourse que havia uma certa variação na altura das plantas em razão da posição em que as mudas se encontravam dispostas na casa de vegetação. Dessa maneira, para eliminar-se esta variabilidade, optou-se pelo delineamento em blocos casualizados agrupando-se em cada repetição plantas que tinham alturas semelhantes.

Em seguida procedeu-se uma coleta de dados de altura das plantas e diâmetro do caule a $3 \mathrm{~cm}$ do colo e através de uma anālise estatística ficou demonstrado que não havia diferenças significativas entre as plantas com relação a estes parâmetros. 
No dia $06 / 11 / 83$ passou-se ägua destilada em abundância no interior dos recipientes, visando remover os nu trientes retidos na sílica e deram-se inicio aos tratamentos.

Os tratamentos obedeceram o seguinte esquema:

1. Completo $-\mathrm{N}_{1}, \mathrm{P}_{1}, \mathrm{~K}_{1}, \mathrm{Ca}_{1}, \mathrm{Mg}_{1}, \mathrm{~S}_{1}+$ micronutrientes

2. Omissão de nitrogênio $-\mathrm{N}_{0}, \mathrm{P}_{1}, \mathrm{~K}_{1}, \mathrm{Ca}_{1}, \mathrm{Mg}_{1}, \mathrm{~S}_{1}+$ + micronutrientes

3. Omissão de fósforo $-\mathrm{N}_{1}, \mathrm{P}_{0}, \mathrm{~K}_{1}, \mathrm{Ca}_{1}, \mathrm{Mg}_{1}, \mathrm{~S}_{1}+$ + micronutrientes

4. Omissão de potássio $-\mathrm{N}_{1}, \mathrm{P}_{1}, \mathrm{~K}_{0}, \mathrm{Ca}_{1}, \mathrm{Mg}_{1}, \mathrm{~S}_{1}+$ + micronutrientes

5. Omissão de cālcio $-\mathrm{N}_{1}, \mathrm{P}_{1}, \mathrm{~K}_{1}, \mathrm{Ca}_{0}, \mathrm{Mg}_{1}, \mathrm{~S}_{1}+$ + micronutrientes

6. Omissão de magnésio $-\mathrm{N}_{1}, \mathrm{P}_{1}, \mathrm{~K}_{1}, \mathrm{Ca}_{1}, \mathrm{Mg}_{0}, \mathrm{~S}_{1}+$ + micronutrientes

7. Omissão de enxofre $-\mathrm{N}_{1}, \mathrm{P}_{1}, \mathrm{~K}_{1}, \mathrm{Ca}_{1}, \mathrm{Mg}_{1}, \mathrm{~S}_{0}+$ + micronutrientes

As soluções nutritivas utilizadas foram formuladas de acordo com SARRUGE (1975) e estão detalhadas na Tabe 1 a 1 .

As plantas eram irrigadas duas vezes ao dia, sen do que no período em que ocorriam temperaturas mais elevadas, era preciso fazer irrigações adicionais para manter a umidade da sílica e evitar o murchamento das plantas devido ao aumento da transpiração.

A drenagem das soluções era feita através de orifícios no fundo de cada recipiente ligados com tubos plásticos aos frascos coletores com capacidade de um litro. 
Tabela 1. Composição química das soluções nutritivas utilizadas no experimento (SARRUGE, 1975).

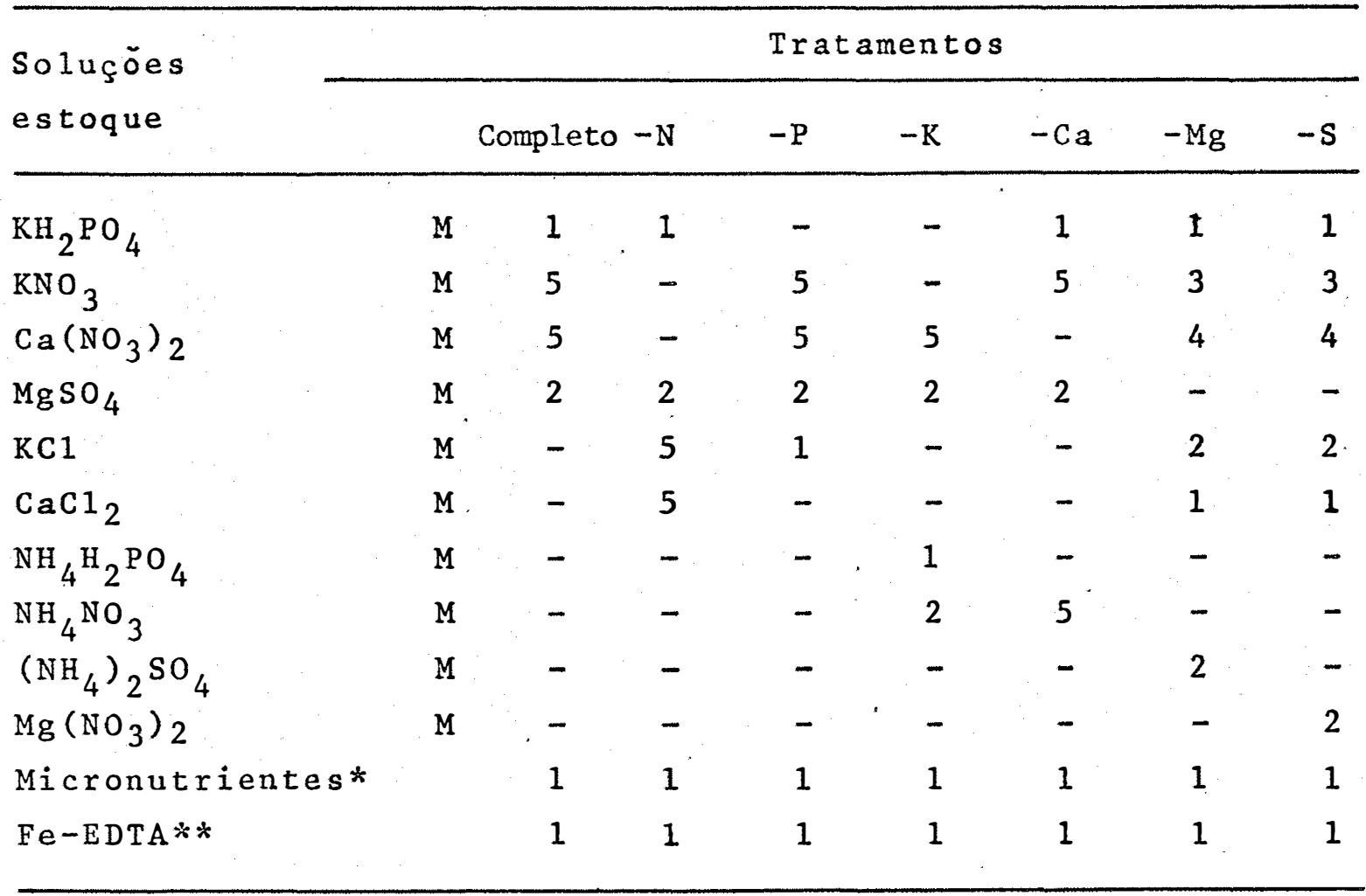

* A solução de micronutrientes tem a seguinte composição ( $/$ / 1): $\mathrm{H}_{3} \mathrm{BO}_{3}, 2,86 ; \mathrm{MnCl}_{2} 4 \mathrm{H}_{2} \mathrm{O}, 1,81 ; \mathrm{ZnCl}{ }_{2}, 0,10 ; \mathrm{CuCl}_{2}, 0,04$; $\mathrm{H}_{2} \mathrm{MOO}_{4} \cdot \mathrm{H}_{2} \mathrm{O}, 0,02$.

* Dissolver 26,1 g de EDTA dissódico em $286 \mathrm{~m} 1$ de $\mathrm{NaOH} \mathrm{N}$; misturar com $24,9 \mathrm{~g}$ de $\mathrm{FeSO}_{4} \cdot 7 \mathrm{H}_{2} \mathrm{O}$. Arejar por uma noite e com pletar a 1 litro.

A solução nutritiva era renovada a cada 20 dias, tomando o cuidado de verificar diariamente o nível da solução nos frascos coletores, completando o volume a um litro, pela adição de água desmineralizada. 
3.1.2. Observações, colheita e preparo para análise

A evolução dos sintomas de deficiências minerais dos macronutrientes foi descrita desde o estágio inicial até tornarem-se bastante definidos, seguido de fotografias to madas para todas aquelas plantas que mostravam intomas típicos marcantes. Para a descrição dos sintomas de deficiência, utilizou-se o Atlas de Cores de villaLOBOS-DOMINGUES e VILLA= LOBOS (1947), o qual permite uma melhor observaçãona descrição da coloração. O sistema de classificação e anotação obedeceu a ordem:

a) a letra ou letras indicam a cor e o seu matiz;

b) o número ou números dão o valor da luminosidade;

c) o grau expressa a tonalidade do matiz.

As plantas foram coletadas em $08 / 04 / 84$, isto é, 153 dias após o início dos tratamentos, tendo já sido evidenciado todos os sintomas de carência minerais estudados. Após serem submetidas a uma lavagem räpi da com água destilada, cada planta colhida foi amostrada em folhas superiores, folhas inferiores, ramos, caule e raízes. As folhas inferiores correspondiam àquelas localizadas no cau le até o lo verticilo (início da ramificação), enquanto que as folhas superiores, correspondiam aquelas que se encontra vam nos ramos. 
0 material separado distintamente foi posto pa ra secar em estufa com circulação de ar em temperatura varian do de 65 a $70^{\circ} \mathrm{C}$, até atingir peso constante e, depois da determinação do peso da matéria seca, foi moído em moinho tipo Wiley, com câmara de aço inoxidável, com peneira de malha 20 (20 malhas por polegada linear), de acordo com as instruçõesde BATAGLIA et alii (1978).

3.1.3. Anālises químicas

As amostras moídas foram submetidas às digestões nítrico perclórica e sulfúrica de acordo com a orienta ção de SARRUGE e HAAG (1974), onde foram determinadas as con centrações dos elementos nos extratos obtidos.

As determinações de nitrogênio foram realizadas através do método analítico do micro kjeldahl (SARRUGE e HAAG, 1974) no Laboratório de Química do Solo do Departamento de Solos, Geologia e Fertilizantes da ESALQ. Para o fósfo ro, as determinações foram feitas por colorimetria pelo método vanado-molibidato de amônio, enquanto que os teores de potássio, cálcio, magnésio, cobre, ferro, manganês e zinco foram determinados por espectrofotometria de absorção atômica no La boratório de Hidrologia e Ecologia Aplicada do Departamento de Silvicultura da ESALQ, de acordo com SARRUGE e HAAG (1974).

As determinações de enxofre foram feitas por turbidimetria da suspensão de sulfato de bārio, após a adição 
de cloreto de bário e realizadas no Laboratório de Nutrição Mineral de Plantas do Centro de Energia Nuclear na Agricultura - CENA, segundo procedimento analítico encontrado em TABATABAI e BREMNER (1970)。

Utilizando-se o método analítico de espectrôme tria de emissão atômica com plasma induzido de argônio (FASSEL, 1979), determinou-se o boro no Laboratório de Radioquími ca e Química Analítica do CENA.

3.1.4. Planejamento experimental e anālises estatísticas

o delineamento estatístico utilizado foi o de blocos ao acaso, com 7 tratamentos e 4 repetições.

Foi realizada anālise de variância dos dados re ferentes a peso da matéria seca das folhas superiores, folhas inferiores, ramos, caule, raiz e planta inteira, assim como concentração de macro e micronutrientes nas diferentes partes da planta. Os nutrientes foram analisados isoladamente, havendo uma anāilse para cada parte amostrada.

As comparações entre as médias dos tratamentos foram efetuadas pelo teste de Tukey, ao nível de $5 \%$ de probabilidade segundo PIMENTEL GOMES (1973).

\subsection{Experimento em campo}

o material utilizado para determinação dos teo 
res de nutrientes foi obtido em populações de freijó (Cordia goeldiana, Huber) com diferentes idades cujas plantas apre sentavam ótimo estado cultural e fitossanitário.

\subsubsection{Localização e caracterização da área}

\section{2 .1 .1 . Local}

o material vegetal utilizado no referido experimento também foi coletado no Campo Experimental de Belterra, localizado na Vila de Belterra, município de Santarēm, Estado do Pará, situado nas coordenadas geogrä́ficas segundo YARED (1983): latitude 02038's, longitude $54^{\circ} 37^{\prime} \mathrm{W}$ e a uma altitude de 175 metros aproximadamente.

\subsubsection{Clima}

Segundo a classificação de küppen, o clima da região é do tipo Ami cujo regime pluviométrico anual define uma estação relativamente seca de um a cinco meses, comefando em julho ou agosto, onde a precipitação mensal chega a ser inferior a $60 \mathrm{~mm}$, porém com um total pluviométrico capaz de manter este período.

No período de 1974-1983, observações meteoroló gicas indicam que a precipitação média anual foi cerca de $1.748 \mathrm{~mm}$, com uma umidade relativa do ar de $90 \%$ e uma insolação de 2.239 horas por ano, enquanto que a temperatura média anual foi de $25,1^{\circ} \mathrm{C}$ e as temperaturas mínimas e máximas mēdias variaram entre $20,6^{\circ} \mathrm{C}$ e $30,5^{\circ} \mathrm{C}$, respectivamente. 
Dados de precipitação pluviométrica, temperatú ra máxima média, temperatura mínima média, temperatura média compensada, umidade relativa do ar e insolação no período 1974 - 1983, registrados na Estação Meteorológica de Belterra, do Instituto Nacional de Meteorologia - INEMET-MA, são apresentados na Tabela 2 .

$3.2 \cdot 1.3$. So 10

A ārea experimental apresenta relevo plano e o solo é classificado como Latossolo Amarelo Distrófico textura muito argilosa (YARED e CARPANEZZI, 1981), cujos dados analíticos de um perfil representativo onde foi coletado material são mostrados na Tabe 1 a 3 .

Para cada idade $(24,36,48$ e 96 meses ), foram coletadas amostras de solo, a uma profundidade de $20 \mathrm{~cm}$ e ana1isadas quimicamente de acordo com os métodos descritos por CATANI e JACINTHO (1974) no Laboratório de Solos do Departamen to de Solos, Geologia e Fertilizantes da ESALQ/USP, cujos re sultados são apresentados na Tabela 4 .

As anālises granulométricas do solo foram feitas pelo método da pipeta, utilizando-se como agente dispersan te hexametafosfato de sódio a $5 \%$, conforme método preconizado por KILMER e ALEXANDER (1949); sendo os resultados obtidos apresentados na Tabela 5 . 


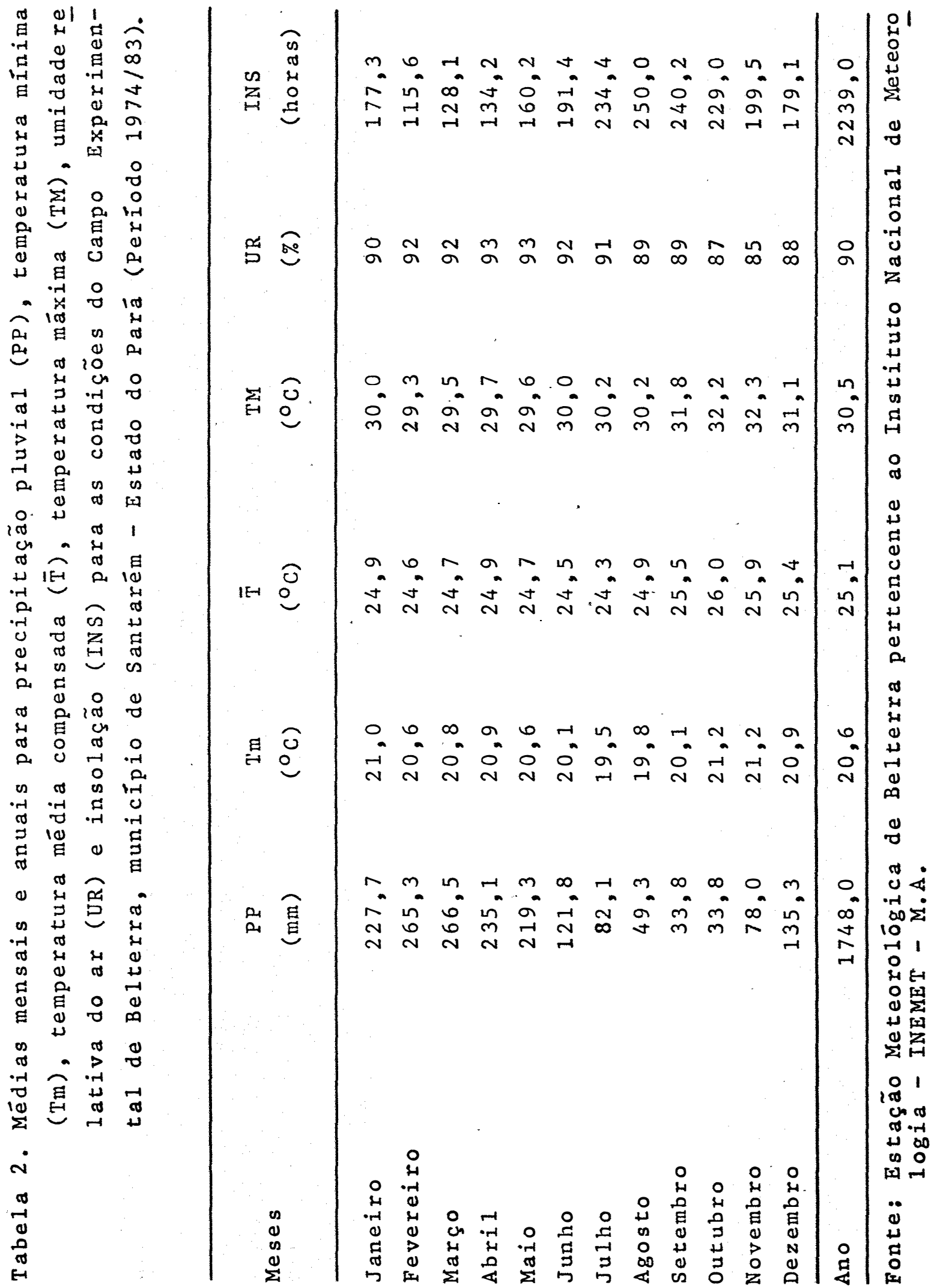




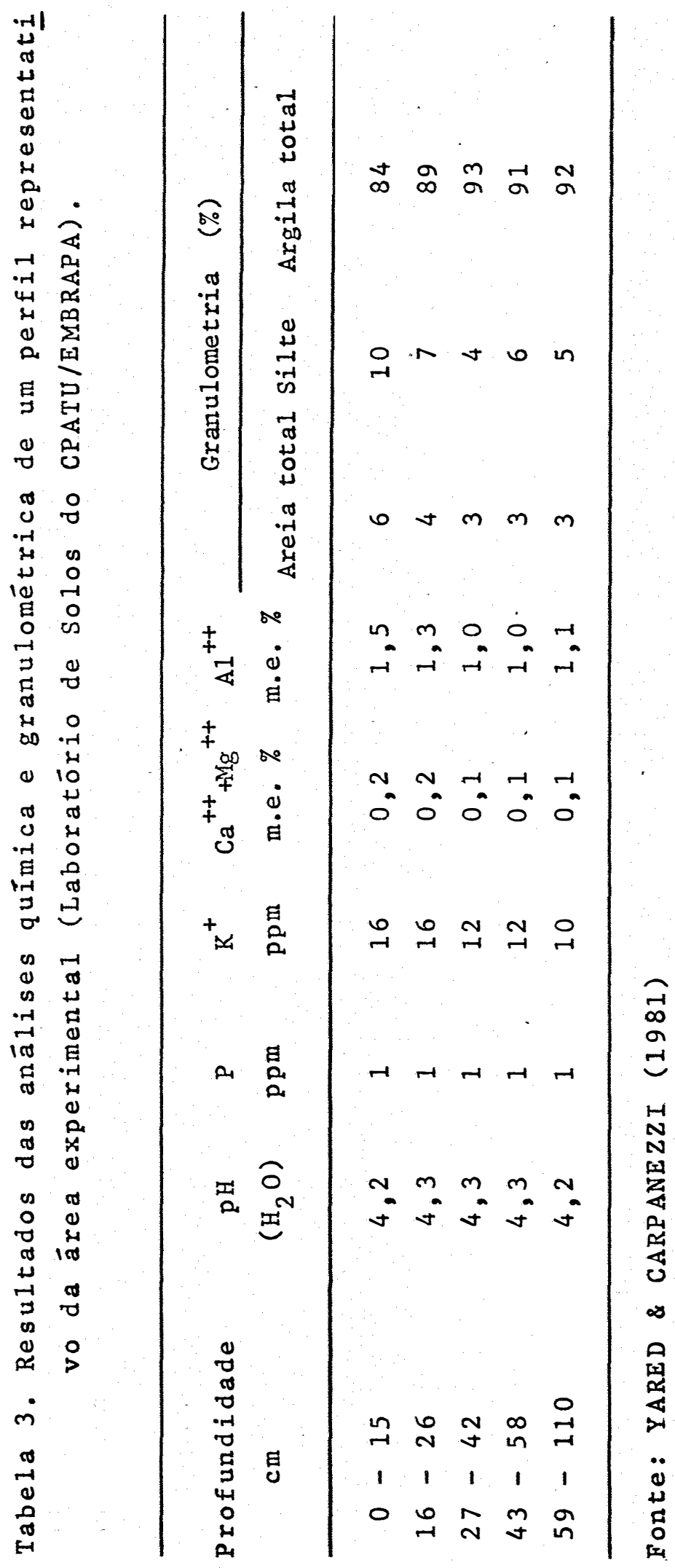




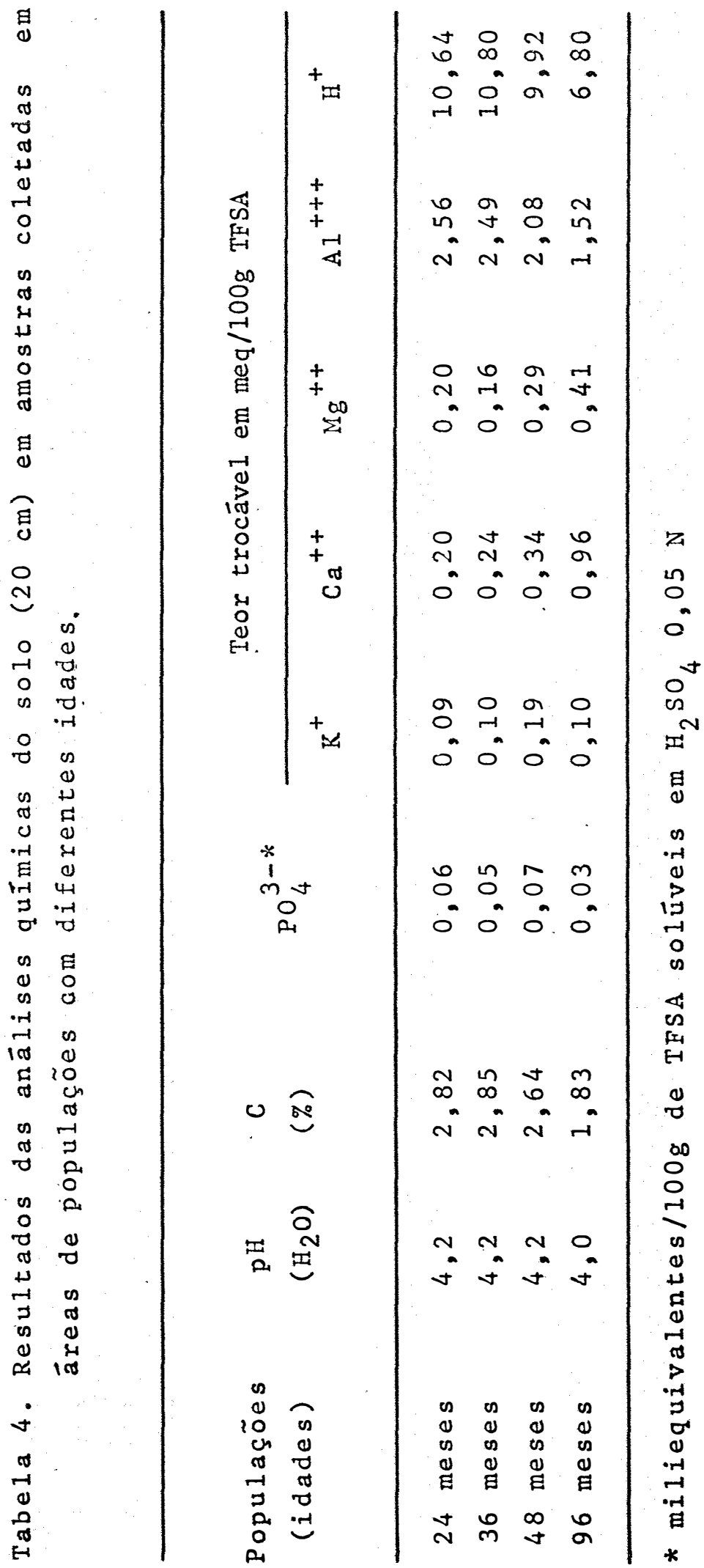


68.

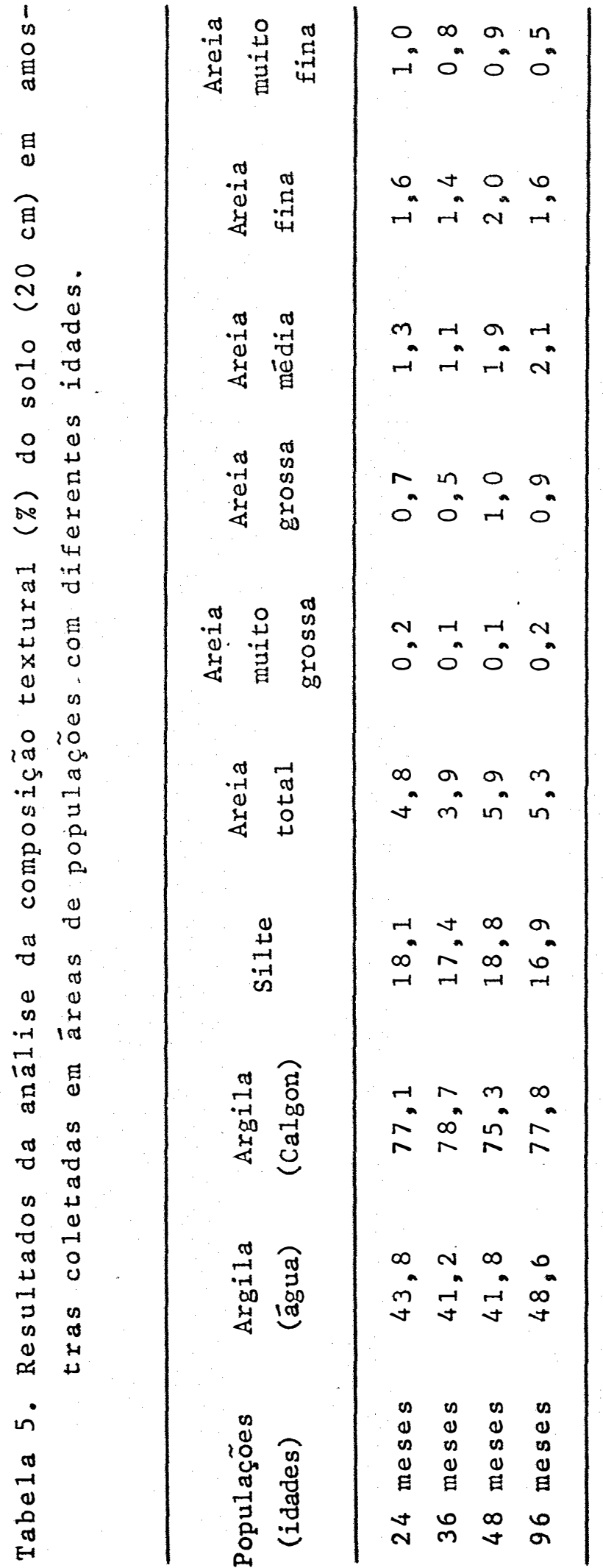




\subsubsection{Seleção do material e coleta das amostras}

No período de $06 / 02$ a $10 / 02 / 84$ foram coletadas plantas de freijo: de diferentes populações, isto é, com 24 meses de idade no espaçamento de $3 \mathrm{~m} \times 3 \mathrm{~m}, 36$ meses de idade espaçadas de $3 \mathrm{~m} \times 3 \mathrm{~m}, 48$ meses de idade de $3 \mathrm{~m} \times 3 \mathrm{~m}$ e com 96 meses de idade com espaçamento $4 \mathrm{~m} \times 4 \mathrm{~m}$. A quantidade de plan tas coletadas foi em nümero de vinte, correspondendo a cinco plantas por idade, onde naqueia ocasião foram retirados dados de altura total de cada planta e diâmetro do caule (DAP - di metro a $1,30 \mathrm{~m}$ do solo).

Após a derrubada cuidadosa das plantas escolhi das foram divididas, em. folhas, ramos e caule, este $\bar{u} 1$ timo dividido em três partes iguais (base, meio e ponta), sendo posteriormente pesadas com o objetivo de se avaliar a extração de nutrientes por planta/idade.

Em seguida retirou-se uma amostra representat $\underline{i}$ va de cada parte da planta, com a finalidade de determinar o peso da matéria seca e análise química:

\subsubsection{Preparo das amostras}

o material colhido como amostragem das divexsas partes, foi levado para o Centro de Pesquisa Agropecuária do Trópico Úmido - CPATU/EMBRAPA, em Belém, Estado do Pará, pesado e colocado em estufa de circulação forçada de ar a 60-650 C com a finalidade de se proceder uma pré-secagem antes de ser en- 
viado para a ESALQ, em Piracicaba, evitando assim uma possível fermentação, principalmente do tecido foliar. Posteriormen te foi feita a secagem final do material também em estufa com a mesma temperatura usada anteriormente e em seguida determi nou-se o peso da matéria seca e moagem em moinho tipo Wiley para análise dos teores de macro e micronutrientes.

\subsubsection{Anālises químicas}

As determinações dos macro e micronutrientes $(\mathrm{N}, \mathrm{P}, \mathrm{K}, \mathrm{Ca}, \mathrm{Mg}, \mathrm{S}, \mathrm{B}, \mathrm{Cu}, \mathrm{Fe}, \mathrm{Mn}$ e $\mathrm{Zn}$ ) nas amostras de fo1has, ramos, ponta do caule, meio do caule e base do caule fo ram efetuadas conforme os métodos anteriormente mencionados no item $3 \cdot 1 \cdot 3$.

\subsubsection{P1anejamento experimental e análises. estatisticas}

Foi utilizado o delineamento experimental inteiramente casualizado com 5 repetições.

Realizou-se anālise de variância dos resultados obtidos referentes à altura das plantas, diâmetro do cau 1e (DAP), produção de matéria seca, concentração e acúmulo de nutrientes pelas diferentes partes das plantas em função da idade (PIMENTEl GOMES, 1973).

Foi feita anālise de regressão para as quanti- 
dades acumuladas, concentração de nutrientes e matēria seca das diversas partes da planta em função da idade para a obten ção dos pontos de mínimo e de mäximo, tomando-se o cuidado de escolher as equações de regressão de maior grau, significativo, tendo como 1 imite a de 29 grau. 


\section{RESUltados E DISCUSSÃO}

4.1. Experimento em casa de vegetação

\subsubsection{Sintomas de deficiências}

Quando um dos nutrientes essenciais à vida da planta não está presente em quantidades satisfatórias ou em condições que o tornam pouco disponível, a deficiência desse nutriente nas células promoverá alterações na sua fisiologia. Esses distúrbios metabólicos, eventualmente se revelam por meio de sintomas visíveis como amarelecimento das folhas, cres cimento reduzido da planta ou outras anomalias. Os sintomas de carência minerais são mais ou menos característicos paraca da nutriente, dependendo também da severidade da deficiência, da espécie ou variedade e de fatores ambientais (Bowen, 1966, citado por EPSTEIN, 1975).

A sintomatologia da deficiência de determinado 
nutriente pode variar de acordo com as espëcies segundo EPSTEIN (1975) e que o conhecimento das causas numa espécie po-derá fornecer poucos subsídios para reconhecê-la em outra.

4.1.1.1. Deficiência de nitrogênio

Aos 65 dias após a omissão do nitro gênio da solução nutritiva, as plantas mostraram os prime ros sintomas de deficiência que se caracterizavam por um retardamento no crescimento das plantas em relação ao tratamento completo e por uma leve clorose (L-9-89) generalizada das folhas inferiores que, gradativamente, alcançava também as su periores. A medida que a deficiência se acentuava, a clorose tomava conta de toda a planta, principalmente das folhas infe riores, que se apresentavam sem brilho natural, mostrando uma coloração verde-limão $(L-14-12 \%)$ e apresentando senescência precoce. Num estádio mais avançado surgiram necrose nos bordos das folhas inferiores, com as plantas apresentando umcres cimento reduzido, internódios curtos, poucas folhas, sem rami ficações ou brotações laterais. A Figura 1 mostra uma planta com sintomas de deficiência de nitrogênio ao lado de uma plantasa dia.

O sistema radicular se mostrava pouco ramifica do quando comparado ao do tratamento completo e suas raízes também apresentavam-se mais finas e mais alongadas.

A sintomatologia descrita está concordante em 


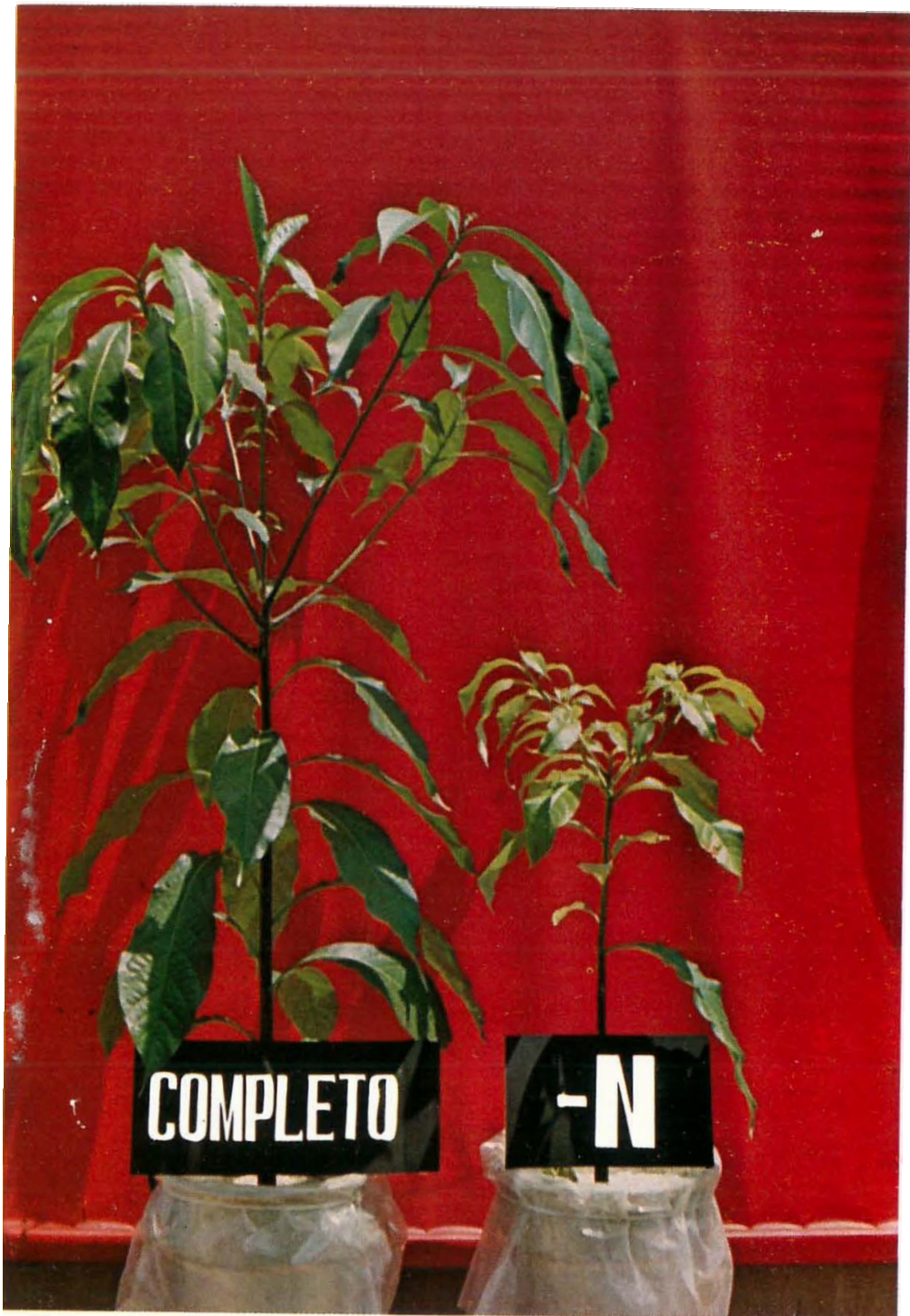

Fig. 1. Comparação entre o tratamento completo e omissão de nitrogênio em plantas de freijó. 
grande parte com as obtidas por ROCHA FILHO et alii (1978b)em Eucalyptus unophylla e HAAG et alii (1981) em Gmelina arborea.

4.1.1.2. Deficiência de fósforo

A deficiência de fósforo foi uma das ültimas a aparecer, iniciando-se os primeiros sintomas aos 105 dias após a omissão desse nutriente.

Esses sintomas de carência começaram pelas folhas inferiores as quais mostravam uma clorose verde mais cla ro (L-10-99) com pequenas manchas de coloração amarelada (YYL-14-109) e arredondadas no limbo f́oliar. Com a evoluçãoda deficiência essas manchas tomavam conta de todo o limbo. foliar e caminhavam progressivamente para uma coloração marrom-escura (OOS-1-89) e as folhas se desprendiam facilmente do cau 1e. Outro sintoma apresentado pelas folhas inferiores eram pequenas manchas amareladas nos bordos do limbo foliar, fican do posteriormente necrosadas. Havia pouca emissão de folhas novas, sendo que algumas delas apresentavam um mosqueamento que se estendia da metade para o ápice das folhas. Observou-se uma pequena redução no porte das plantas quando. comparadas àquelas cultivadas em solução nutritiva completa.

A Figura 2 mostra uma planta com sintomas de deficiência de fósforo em comparação com uma sadia, enquanto que a Figura 3 mostra detalhes da carência do elemento.

O sistema radicular apresentava-se menos desenvolvido que aquele correspondente a plantas sadias. 


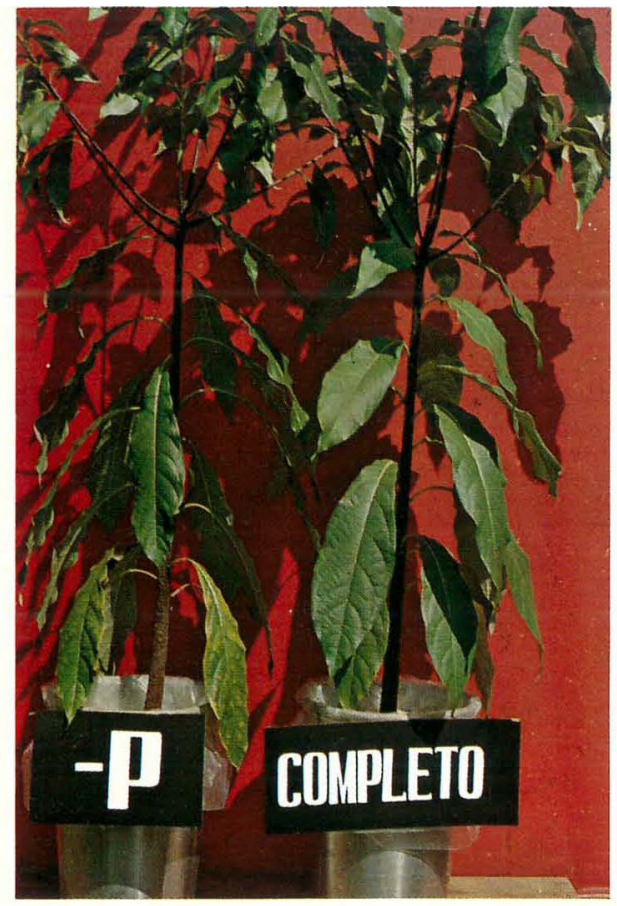

Fig. 2. Comparação entre o tratamento completo e omis são de fósforo em plan= tas de freijó.

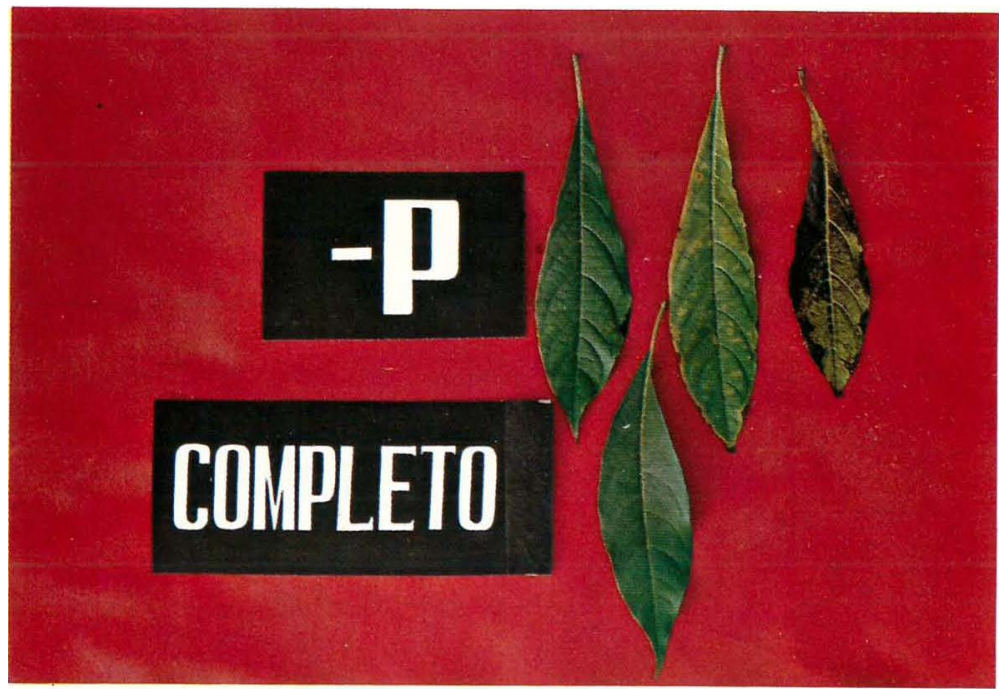

Fig. 3. Sintomas de deficiência de fósforo em fothas inferiores de freijo. 
raízes eram alongadas, mais grossas que o normal, com poucas ramificaçöes e extremidades escurecidas.

Os sintomas obtidos têm algumas semelhanças com os descritos por HAAG et alie (1981) em Gmelina arborea e RoCHA FILHO et alii (1978b) em Eucalyptus urophylla.

4.1.1.3. Deficiência de potássio

Logo após o aparecimento dos sintomas de carência de nitrogênio, istoé, 90 dias, surgiram os pri meiros sintomas de deficiência de potásio.

Folhas inferiores apresentavam uma discreta co loração amarelada $(Y-13-89)$, com pequenas manchas mais ou menos circulares e outras de forma irregular e de coloração fer ruginosa (oos-7-109) entre as nervuras secundárias,principalmente do meio para o ápice da folha. Com a evolução da deficiência, essas manchas aumentavam de tamanho unindo-se, formando faixas transversais necrosadas no tecido compreendidoen tre a nervura principal e o bordo foliar. Na face inferior ou dorsal da folha, a nervura principal se mostrava escurecida o mesmo acontecendo com algumas nervuras secundárias, bem como o pecíolo, ocorrendo algumas vezes a queda da folha.

Outro sintoma característico observado foi a ocorrência nas folhas inferiores de pontos cloróticos na ārea do limbo foliar e particularmente nas margens das folhas que rapidamente se uniam formando faixas cloróticas que se localizavam nos bordos e ápice das folhas. Com a progressão dos 
sintomas, as faixas cloróticas passavam a uma necrose marginal que se iniciava pelo āpice das folhas levando posteriormente a um räpido desenvolvimento de uma clorose onde apenas o tecido da base da folha e aquele adjacente à nervura mediana permaneciam mais esverdeada.

A Figura 4 mostra uma planta com sintomas de ca rência de potāssio em comparação a uma desenvolvida em solução nutritiva completa, enquanto que aFigura 5 mostra detalhes da deficiência do nutriente.

No desenvolvimento das plantas com sintomas de deficiência de potássio, houve uma pequena redução nó ritmo de crescimento em altura, porém o sistema radicular apresentava em menor tamanho quando comparado aos das plantas desenvolvidas em solução nutritiva completa.

Os sintomas observados apresentam uma certa discordância.com aqueles obtidos por HAAG et alie (1981), em Gmelina arborea, ROCHA FILHO et alii (1978b) em Eucalyptus urophylla e por SIMÕES (1973) em Araucaria angustifolia.

4.1.1.4. Deficiência de cảlcio

A deficiência de cảlcio foi a ủltima a aparecer, iniciando-se aos 115 dias apös a omissão desse nutriente.

Inicialmente os sintomas de carência de cálcio ocorreram nas folhas superiores as quais apresentavam manchas cloróticas verde-amareladas (LLY-14-99) e que posteriormente 


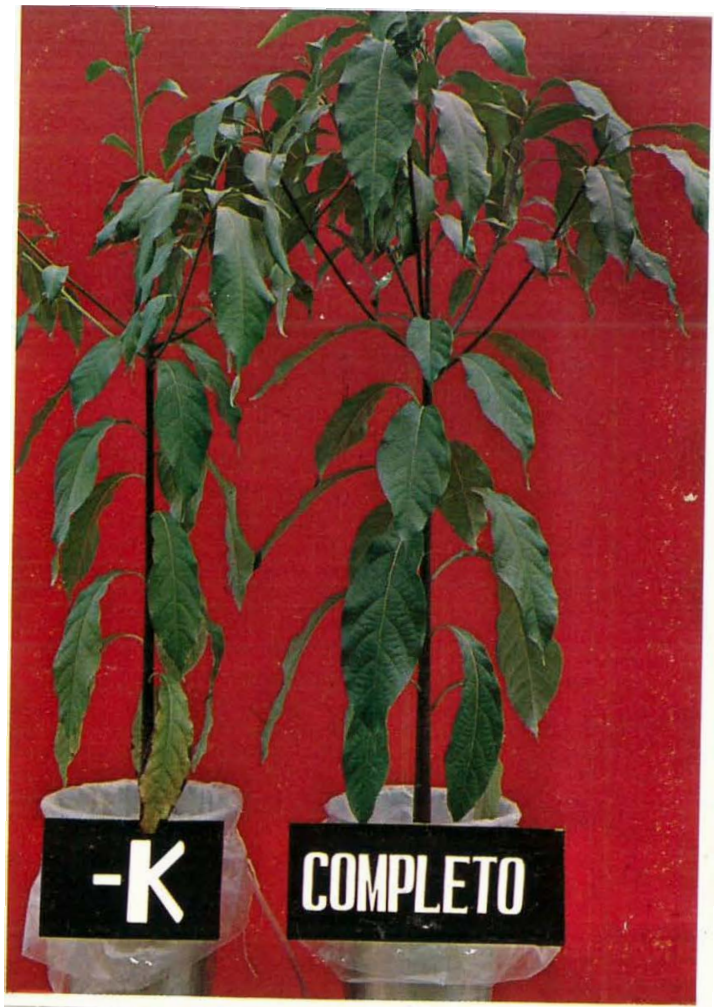

Fig. 4. Comparação entre tratamento com pleto e omissão de potássio e $\vec{m}$ plantas de freijó.

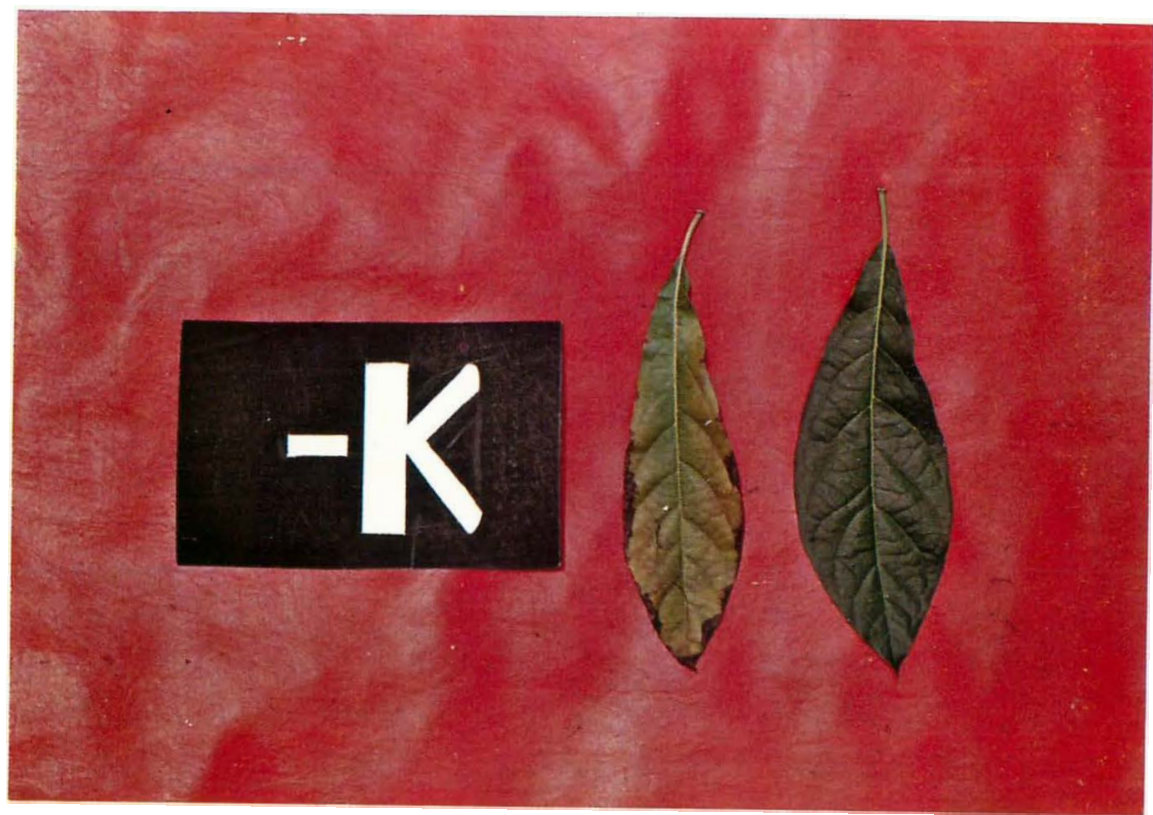

Fig. 5. Sintomas de deficiência de potássio em folhas inferiores de freijó. 
progrediam para as folhas inferiores. Estas mostravam uma clo rose esverdeada (L-6-109) e um amarelecimento em alguns pontos da margem das folhas que algumas vezes tornavam-se necróticas.. Com a evolução da deficiência, as Eolhas inferiores ficavam com uma coloração amare1o-1imão (YL-12-109) onde surgiram manchas de coloração avermelhada (0os-8-69) evoluindo mais tarde para marrom (oss-3-89).

o broto termina 1 , praticamente sem emissão de folhas novas, mostrava algumas delas murchas com o àpi ce voltado para a base da planta.

A Figura 6 mostra uma planta com sintomas de deficiência de cảlcio em comparação a uma sadia, enquanto que a Figura 7 mostra detalhes da carência do elemento.

o crescimento das plantas não foi prejudicado pela carência de cälcio, havendo um maior reflexo no sistema radicular o qual se mostrou escurecido e de tamanho reduzido. Os sintomas obtidos não concordam com aqueles descritos por HAAG et alii (1961b) em Eucalyptus alba e por HAAG et alii (1981) em Gmelina arborea.

4.1.1.5. Deficiência de magnésio

Os sintomas de deficiência de magnésio surgiram praticamente na mesma ëpoca em que apareceu a carência de cálcio, isto é, aos 110 dias do início do tratamento. efetivamente. 


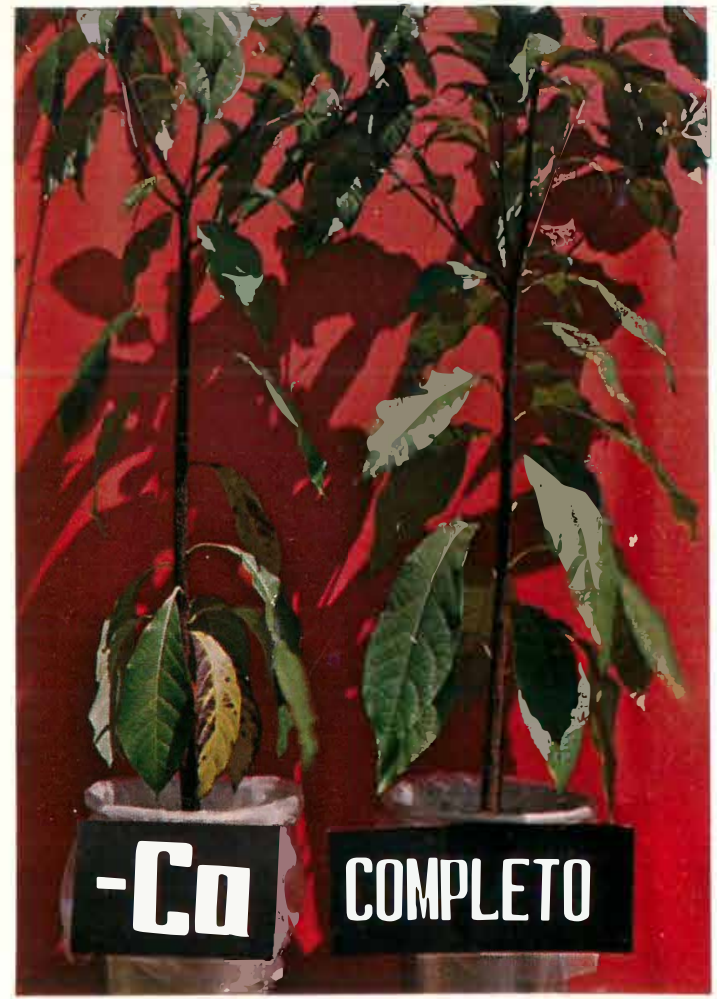

Fig. 6. Comparação entre tratamento com pleto e omissão de cálcio ễ plantas de freijó.

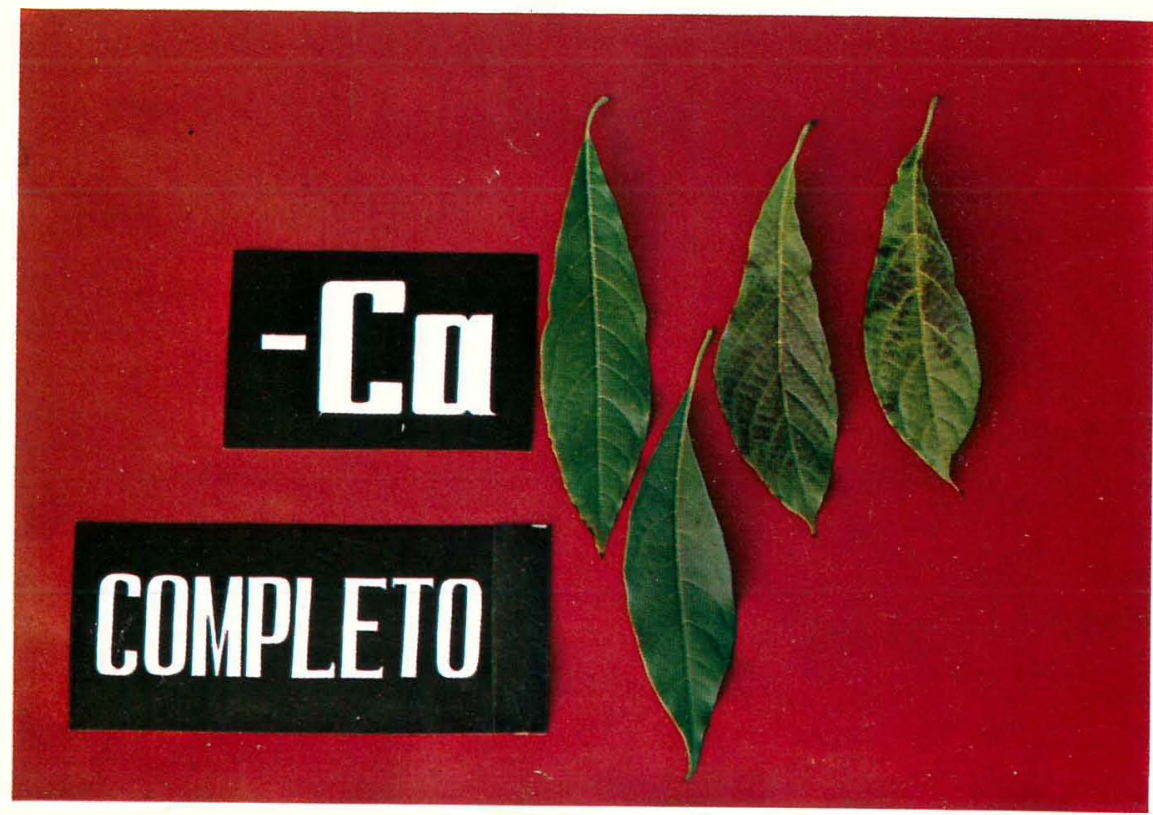

Fig. 7. Sintomas de deficiência de cálcio em folhas inferio res de freijó. 
Os sintomas se manifestaram inicialmente com manchas internervais levemente cloróticas, amareladas (Y-15-89) na base do $1 \mathrm{imbo}$ das folhas inferiores, sendo estes sintomas ascendentes. A progressão dos sintomas foi relativamente rāpida, e com a evolução da carência, essa clorose inicial mente verde-amarelada tornou-se de coloração amarelo intenso (Y-16-119) que se estendia em grande parte pelo bordo ou margem do 1 imbo foliar, ficando a região central, ou seja, que margea a nervura principal com uma coloração esverdeada (LLY -9-89). Os bordos ou margem do limbo foliar que se encontrava amarelo intenso, com o desenvolvimento da deficiência chegavam a necrosar. Em algumas folhas apareciam numerosas e pequenas manchas de coloração ferruginosà (0os-5-6!) no 1 imbo foliar que se aglomeravam formando grandes manchas nos espaços compreendidos entre as nervuras secundárias.

A Figura 8 mostra uma planta com sintomas de carência de magnésio em comparação a uma sadia, enquanto que a Figura 9 mostra detalhes da deficiência do elemento.

0 crescimento das plantas com sintomas de carência de magnésio mostrava-se de menor porte quando comparado com as plantas sadias, enquanto que o sistema radicular não foi prejudicado.

Os sintomas obtidos mostram uma certa semelhan ça com aqueles relatados por ROCHA FILHO et alii (1978b) com Eucalyptus urophylla, porém discordam daqueles descritos por 


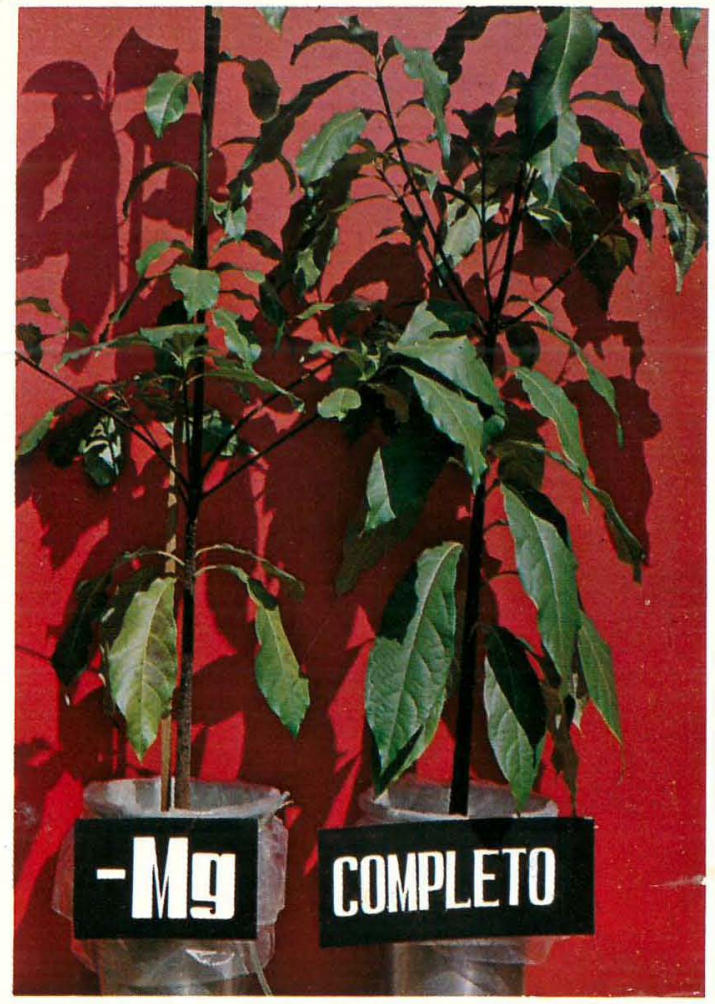

Fig. 8. Comparação entre tratamento com pleto e omissão de magnésio em plantas de freijó.

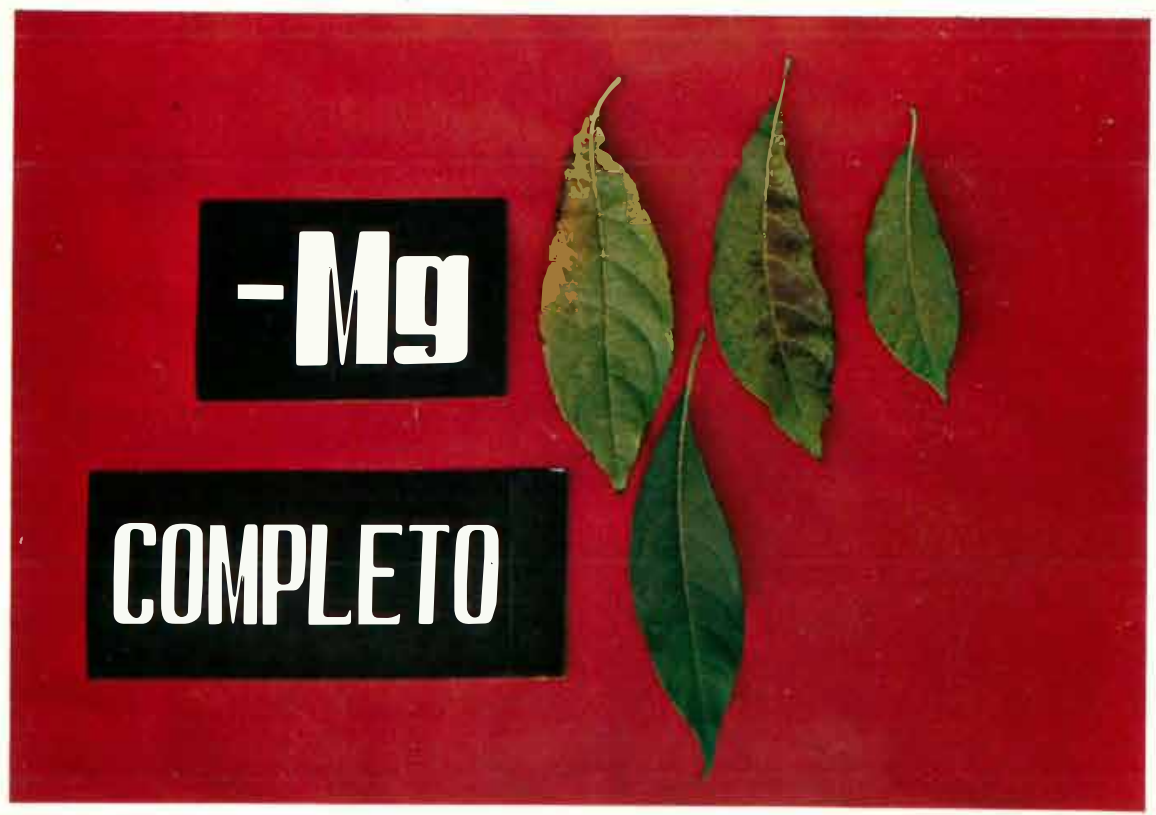

Fig. 9. Sintomas de deficiência de magnésio em folhas in feriores de freijó. 
HAAG et alii (1981) em Gmelina arborea e por SIMÕES

em Araucaria angustifolia.

\subsubsection{Deficiência de enxôfre \\ Aos 80 dias após a omissão do enxofre,}

plantas mostravam os primeiros sintomas de deficiência caracterizado por uma coloração amarelada brilhante uniforme, atin gindo totalmente o limbo foliar das folhas superiores, as quais progressivamente iam se tornando de cor verde-1imão (YL-14-109), distinguindo-se nitidamente das folhas inferiores que apresentavam uma coloração verde-escuro (LG-5-6o), semelhantes às das plantas sadias. No decorrer do ensaio observou - se que às vezes havia regressão desses sintomas, com as folhas voltando à coloração natural e vice-versa, entretanto é possí vel que isso tenha ocorrido devido a pröpria absorção desse nutriente pelas folhas, na forma gasosa, visto o experimento ter-se realizado relativamente pröximo a indüstrias.

Outro sintoma verificado nas folhas superiores era o tamanho ligeiramente reduzido quando comparadas com as das plantas sadias cultivadas em solução nutritiva completa. Com a intensificação da carência de enxofre, al gumas folhas inferiores apresentaram uma clorose verde-amarelada (LLY-9-79), passando posteriormente para uma coloração amarelada (YYL-15-10 $)$, aparecendo a partir daí manchas de di. ferentes tamanhos e forma irregular de coloração ferruginosa 
(00s-6-109) e que mais tarde se uniam formando grandes äreas necrosadas.

A Figura 10 mostra uma planta com sintomas de cä rência de enxofre nas folhas inferiores, a Figura,11 mostra sintomas iniciais de carência, enquanto que a Figura 12 mostra detalhes da deficiência do elemento nas folhas superiores e inferiores. As plantas deficientes em enxofre mostraram um crescimento relativamente menor que as plantas sadias, o mesmo acontecendo com o' sistema radicular que apresentou um menor volume.

Os sintomas de deficiêricia de enxofre são semelhantes aqueles obtidos por ROCHA FILHO et alii (1978b) em Eucalyptus urophylla, porèm discordantès em vārios pontos com aqueles descritos por SIMÕES (1973) em Araucaria angustifolia.

\subsubsection{Desenvolvimento das plantas}

O desenvolvimento das p1antas foi ava1iado através dos dados de peso de matéria seca total e das diferentes partes da planta em função dos tratamentos, cujos resultados e o resumo da anāilse de variância, são apresentados na Tabela 6 .

Conforme os dados contidos na Tabela 6 , observa-se que a omissão de nitrogênio da solução nutritiva causou uma diminuição na produção de matéria seca tota1, o mesmo acontecendo para as diversas partes amostradas da planta. Es- 

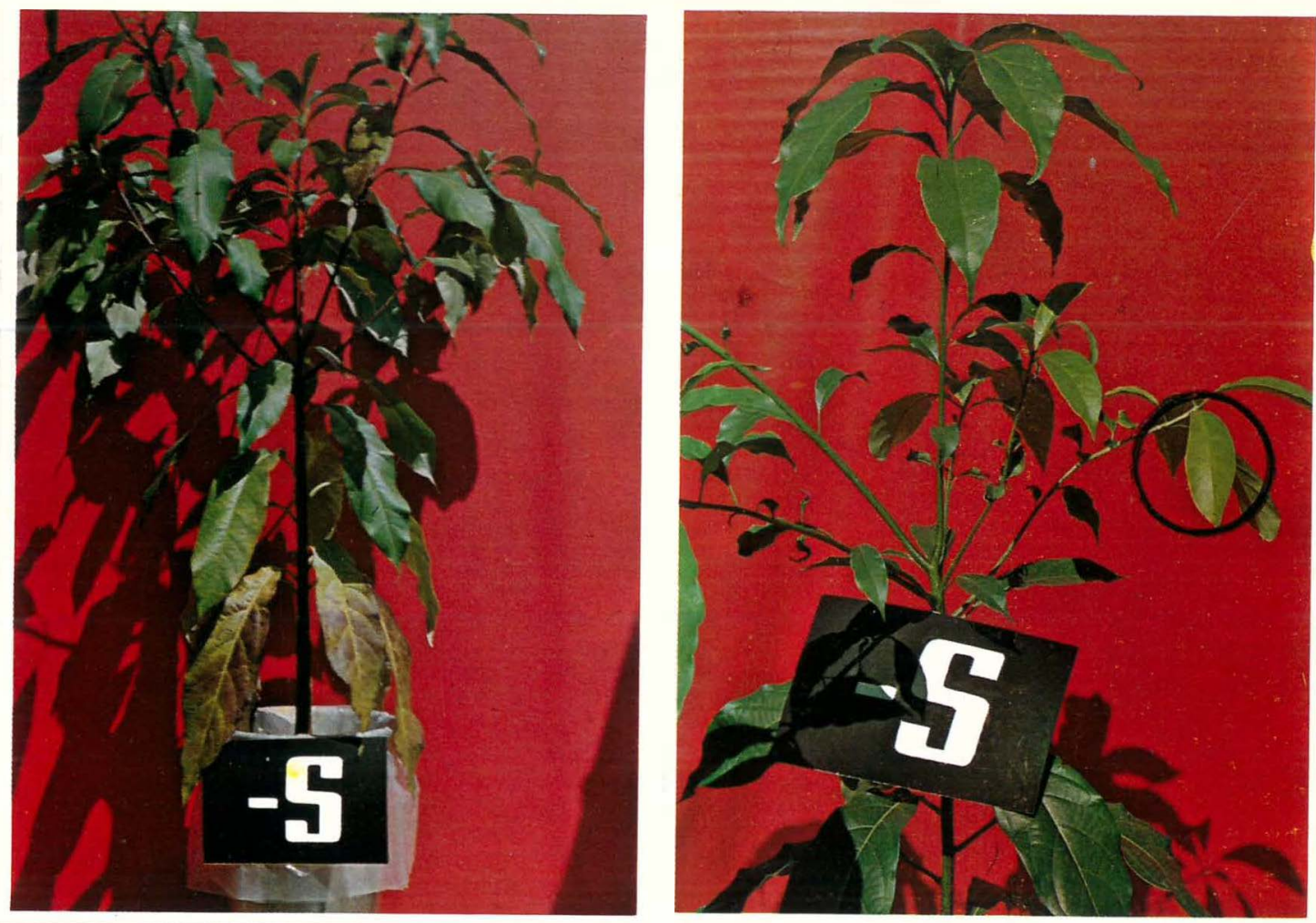

Fig. 10. Planta. de freijó mostran do deficiência de enxofre em folhas inferiores.
Fig. 11. Planta de freijó mostran do deficiência de enxo= fre em folhas superiores.

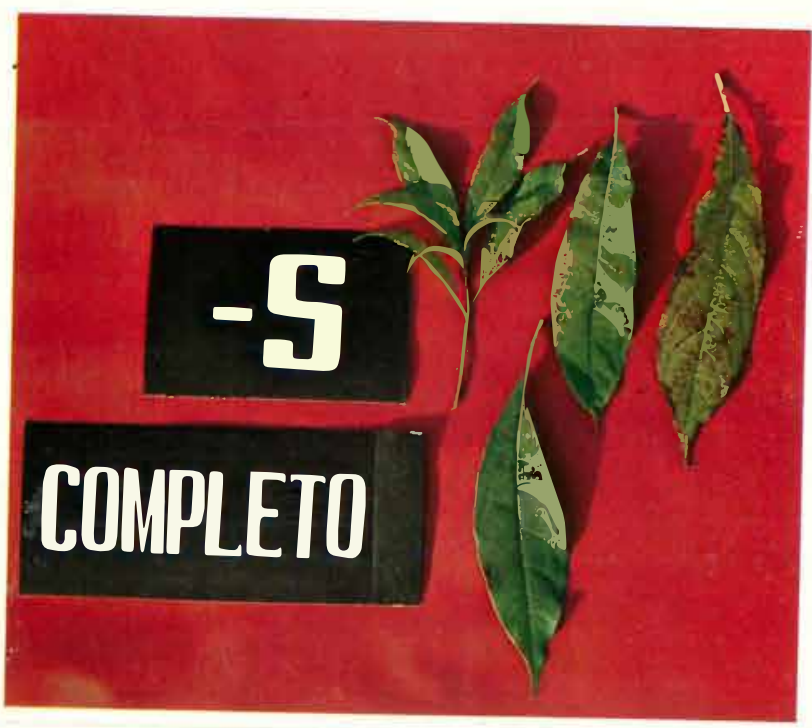

Fig. 12. Sintomas de deficiência de enxo fre em folhas superiores e infe riores de freijō. 


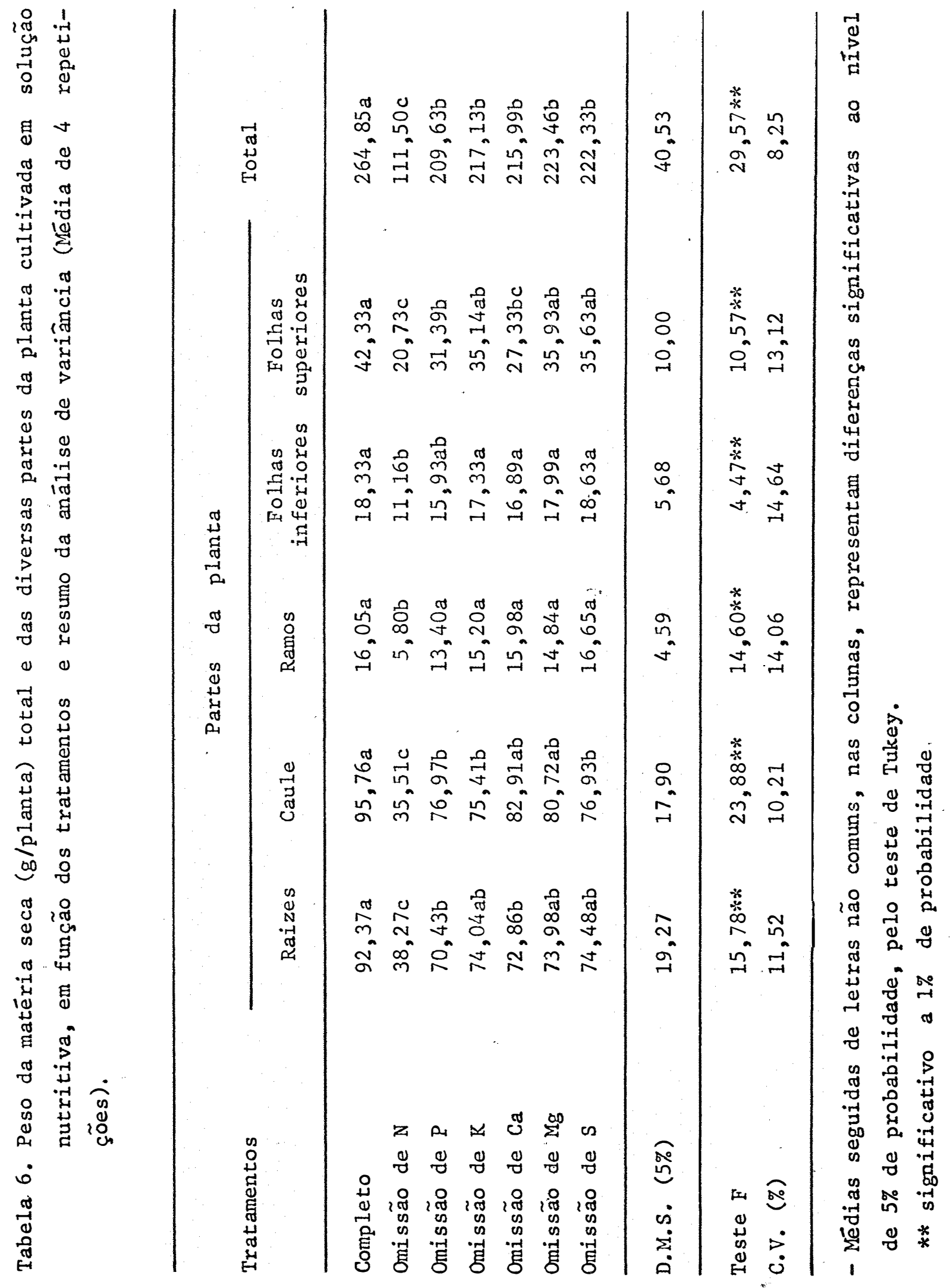


se elemento é considerado como um dos principais na vida das plantas, pois é um dos constituintes dé todas as proteínas,aminoảcidos, nucleotídeos e coenzimas, sendo dessa maneira um nutriente que quando omitido provoca alterações no metabolismo das plantas com conseqüentes prejuízos no seu desenvolvimento (EPSTEIN, 1975).

A omissão de fósforo não afetou o desenvolvimento das folhas inferiores e ramos entretanto, motivou uma redução na produção de matéria seca das folhas novas, caule e raízes, refletindo na produção total da planta.

A redução da produção de matéria seca com a omissão de potássio foi mais acentuada no caule, enquanto as outras partes amostradas da planta tiveram um comportamentose melhante ao tratamento completo.

Constata-se também através da Tabela 6, que a omissão de cálcio participou somente na diminuição da produção de matéria seca das folhas superiores e raízes, enquanto que o desenvolvimento do caule, ramos e folhas inferiores não mostrou diferença quando comparado ao tratamento completo.

Por outro lado, observa-se que a omissão de magnésio não teve influência na produção de matēria seca das diferentes partes da planta, o mesmo acontecendo com o enxofre o qual mostrou apenas uma exceção com relação ao caule que teve o desenvolvimento afetado pela ausência deste elemen to. 
De uma maneira geral, embora algumas partes da planta tenham tido comportamento semelhante ao completo comre 1 ação a produção de matéria seca, todos os tratamentos com omissão de nutrientes foram inferiores ao completo no tocante à matéria seca total.

o nitrogênio foi o elemento que mais limitou a produção de matéria seca total, fato este já conhecido e ob servado em inūmeras espécies, como por exemplo HAAG et alii (1981) em Gmelina arborea e RoCHA FILHO et alii (1978b) em Eucalyptus urophylla.

A omissão de nutrienteś da solução nutritiva afetou o desenvolvimento das plantas através da redução dapro dução de matéria seca, na seguinte ordem decrescente: nitrogênio, fósforo, cālcio, potássio, enxofre e magnésio.

\subsubsection{Concentração de nutrientes}

\subsubsection{Nitrogênio}

Os valores médios dos teores de nitrogênio nas diversas partes da planta, bem como o resumo da anāilise de va riância, encontram-se na Tabela 7 .

Vèrifica-se que a omissão de nitrogênio da solução nutritiva causou uma redução na concentração desse elemento em todas as partes amostradas da planta, em confronto com o tratamento completo. AMARAL (1983) observou o mesmo fato em seringueira. 


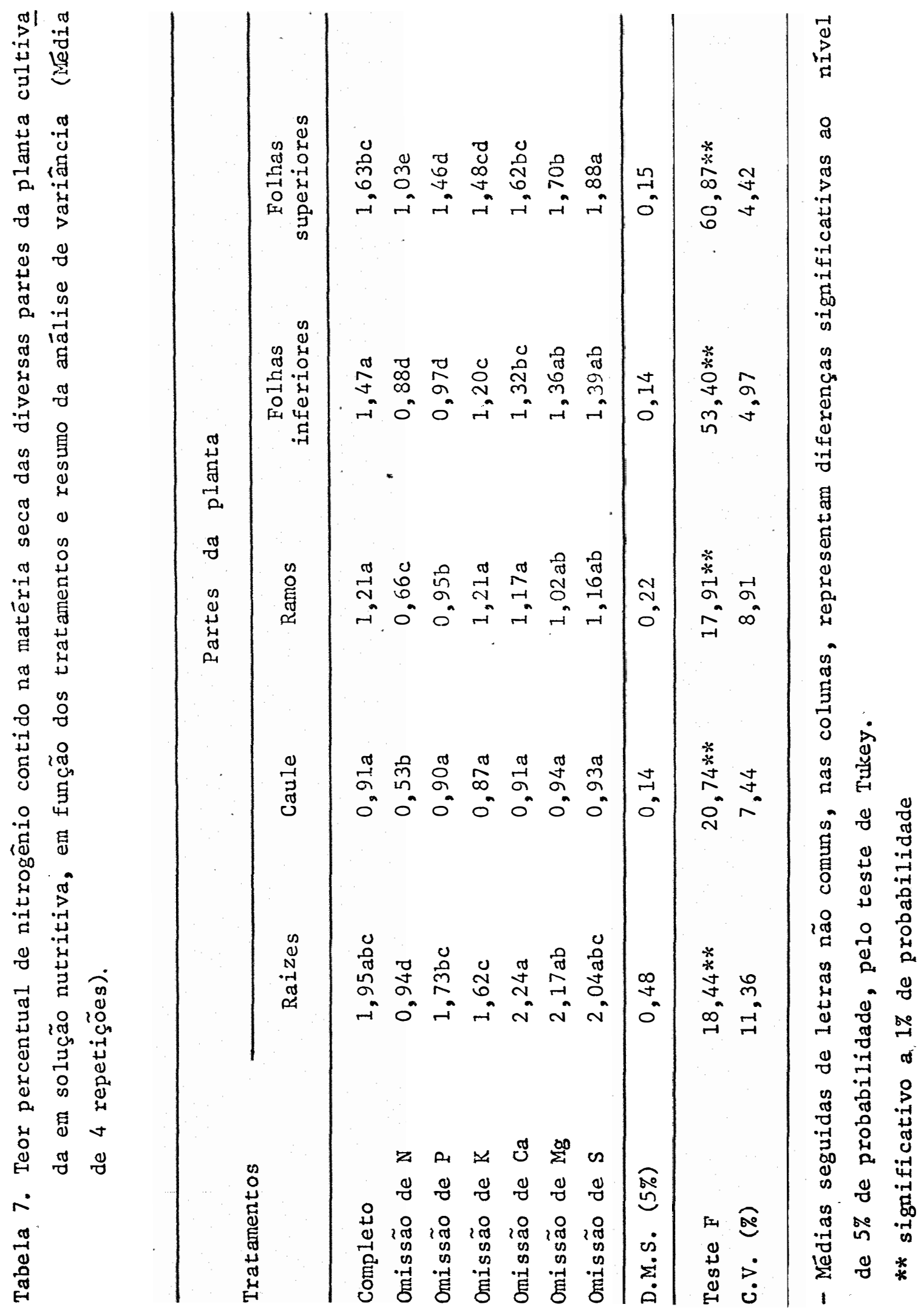


o tratamento deficiente em fósforo provocou uma diminuição no teor de nitrogênio nos ramos, folhas inferiores e superiores em relação ao tratamento completo.

Com a omissão do potássio e cālcio da solução nutritiva, apenas os teores de nitrogênio nas folhas inferiores foram mais baixos e diferiram do tratamento completo.

Alguns autores como CIBES e SAMUELS (1955) e HAAG (1958) trabalhando com cafeeiro observaram que a omissão de potásio elevou a concentração de nitrogênio nas folhas. RI CHARD e BERNER (1954) relataram que plantas deficientes em potássio apresentam teor elevado de aminoácidos livres em seus tecidos.

Por outro 1ado, MACHICADO e BOYNTON (1961), en contraram alta concentração de nitrogênio em folhas de cacau cultivado em soluções nutritivas deficientes em potássio ou magnésio. o teor de nitrogênio nas folhas dessas plantas foi superior ao encontrado nas de plantas do tratamento completo.

As plantas deficientes em enxofre apresentaram um aumento significativo na concentração de nitrogênio apenas nas folhas superiores em relação ao tratamento completo. Segundo GILBERT (1951) plantas carentes em enxofre apresentam, em geral, alta concentração de nitrogênio em seus tecidos.

\subsubsection{Fösforo}

os valores mëdios das concentrações nas diver- 
sas partes da planta e o resumo da anāilse de variância acham -se na Tabe 1 a 8 .

Em confronto com o tratamento completo observa-se que a omissão de fósforo na solução nutritiva motivou uma diminuição no teor desse elemento em todas as partes amostradas. Conclusão semelhante foi obtida com seringueira por AMARAL (1983), apesar de não ter havido éfeito sobre o cresci mento das plantas.

Omitindo nitrogênio da solução nutritiva houve um aumento acentuado na concentração de fósforo no caule, fothas inferiores e superiores quando comparadas com os mesmos ơrgãos de plantas cultivadas em solução completa, o que provavelmente se deva a uma redução no conteúdo de matéria.seca para este tratamento, elevando a concentração do elemento em questão. Fato semelhante ocorreu em relação aos tratamentos referentes à omissão de potássio, cảlcio e magnésio provocando também um aumento significativo nos teores de fósforo nas folhas inferiores e superiores.

\section{$4 \cdot 1 \cdot 3 \cdot 3$. Potás io}

As concentrações médias de potássio para

diferentes partes das plantas, como também o resumo da anälise de variância, são mostrados na Tabela 9.

Observa-se que o teor de potássio nas diversas partes da planta diminuiu acentuadamente em relação ao tratamento completo quando se omitiu este nutriente no supri- 
93.

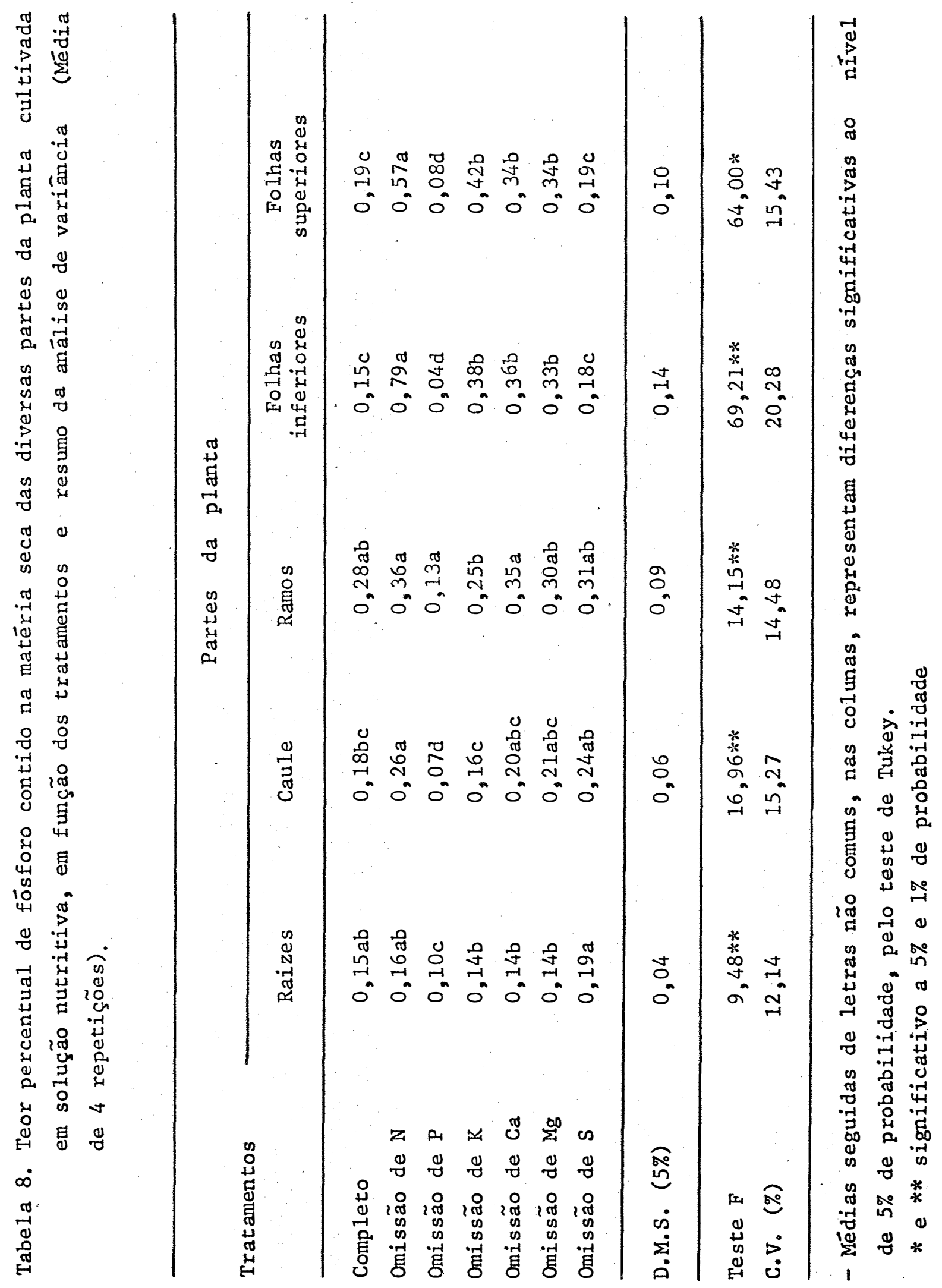




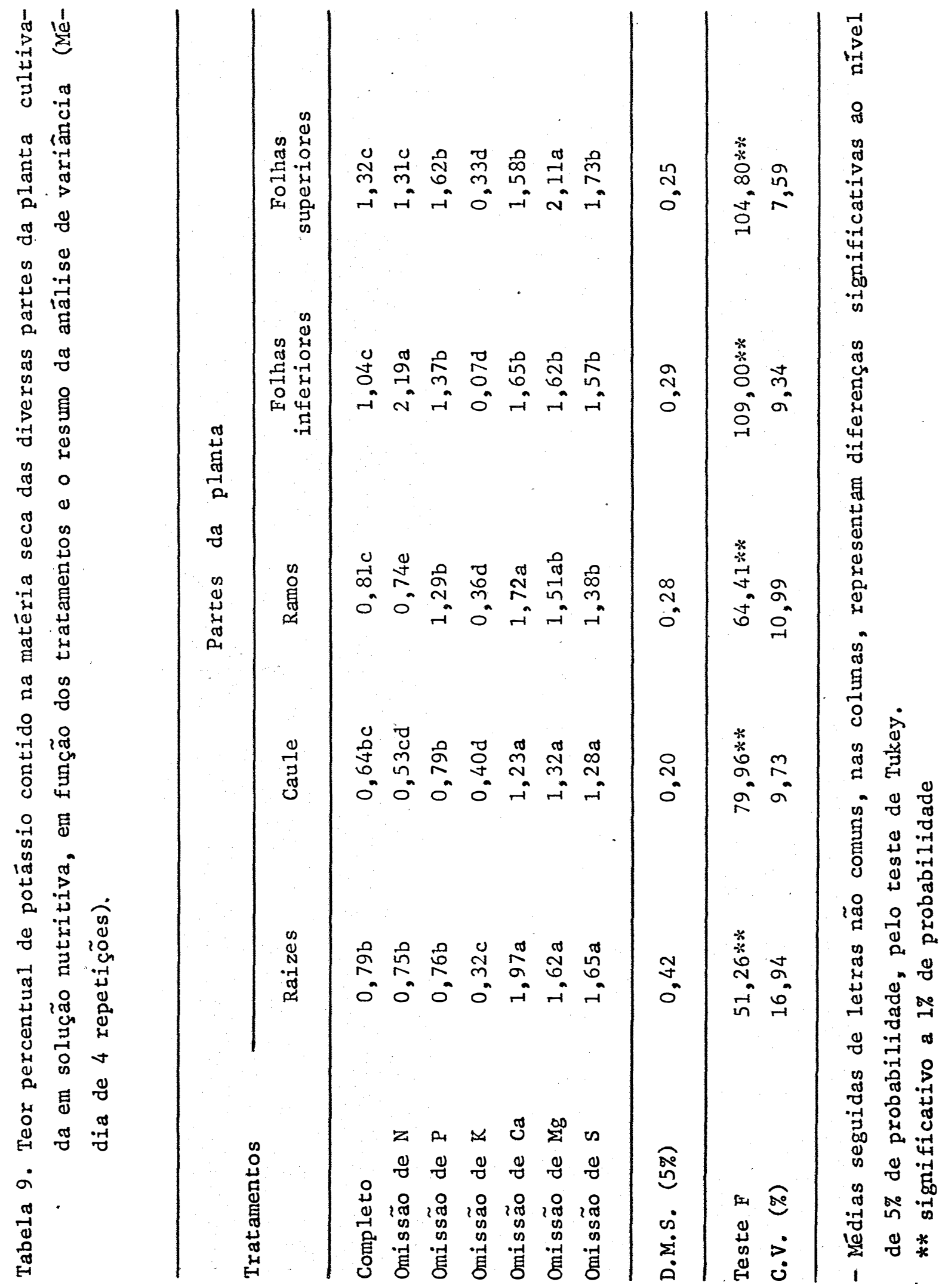


mento mineral das plantas, fato este também observado por HEWITT (1951), BUKOVAC e WITTWER (1957) e ULRICH e OHKI em outras espécies.

A Tabela 9 mostra ainda que omitindo o nitrogênio da solução, houve diferença apenas na concentração de potássio das folhas inferiores, sendo este teor mais alto quando comparado ao tratamento completo. Estudando alguns aspectos nutricionais da seringueira em solução nutritiva, AMARAL (1983) observou o mesmo efeito.

Por outro lado, MENGEL et alie (1976) relatam que o potássio näo influencia somente a translocação de compostos nitrogenados para os grãos, como também exerce efeito positivo no transporte dos mesmos da raiz para a parte aérea da planta.

Com a omissão de fósforo da solução nutritiva verifica-se um aumento da concentração de potássio nos ramos, folhas inferiores e superiores em relação ao tratamento comp leto.

Finalmente observa-se que quando se omitiu o cálcio, magnésio ou enxofre da solução, houve um acréscimo expressivo na concentração de potássio em todos os órgãos da planta. MENGEL e’ASKAY (1954) observaram, em solução nutritiva, que o cälcio pode ou não apresentar efeito sobre o potássio, inibindo ou estimulando a sua absorção.

Segundo ULRICH e OHKI (1966), níveis de potássio nas folhas de plantas com necessidade normal do elemento, 
estão entre $0,70 \%$ a $1,50 \%$ do peso do material seco. Para plantas muito exigente em potássio, esse nível poderá ser igual ou superior a $5 \%$. Os valores médios obtidos no presente trabalho para folhas inferiores sem deficiência de $1,04 \%$ e para folhas superiores $1,32 \%$ estão dentro dos níveis estabelecidos para folhas de plantas com requerimento normal de potássiocon siderando os dados dos referidos autores.

\subsubsection{Cálcio}

Na Tabela 10 estão os teores médios de cálcio nas diferentes partes da planta, bem ćomo o resumo da análít: se de variância.

Através dos dados verifica-se que as maiores concentrações de cálcio ocorrem nas folhas inferiores o que confirma a pouca mobilidade deste nutriente na planta. Na literatura muitas citações sobre a pequena mobilidade do elemento são encontradas, como EPSTEIN (1975), MENGEL e KIRKBY (1978) entre outros.

Observa-se pela Tabela 10 , que houve redução na concentração de cálcio nas diversas partes da planta, quan do se omitiu este elemento da solução, em comparação ao tratamento completo. Os mesmos resultados foram observados por AMARAL (1983) trabalhando com seringueira.

$\mathrm{Na}$ mesma Tabela constata-se que omitindo o ni trogênio da solução nutritiva motivou um menor teor de cálcio nos ramos, folhas inferiores e superiores, sendo estes teo 
97.

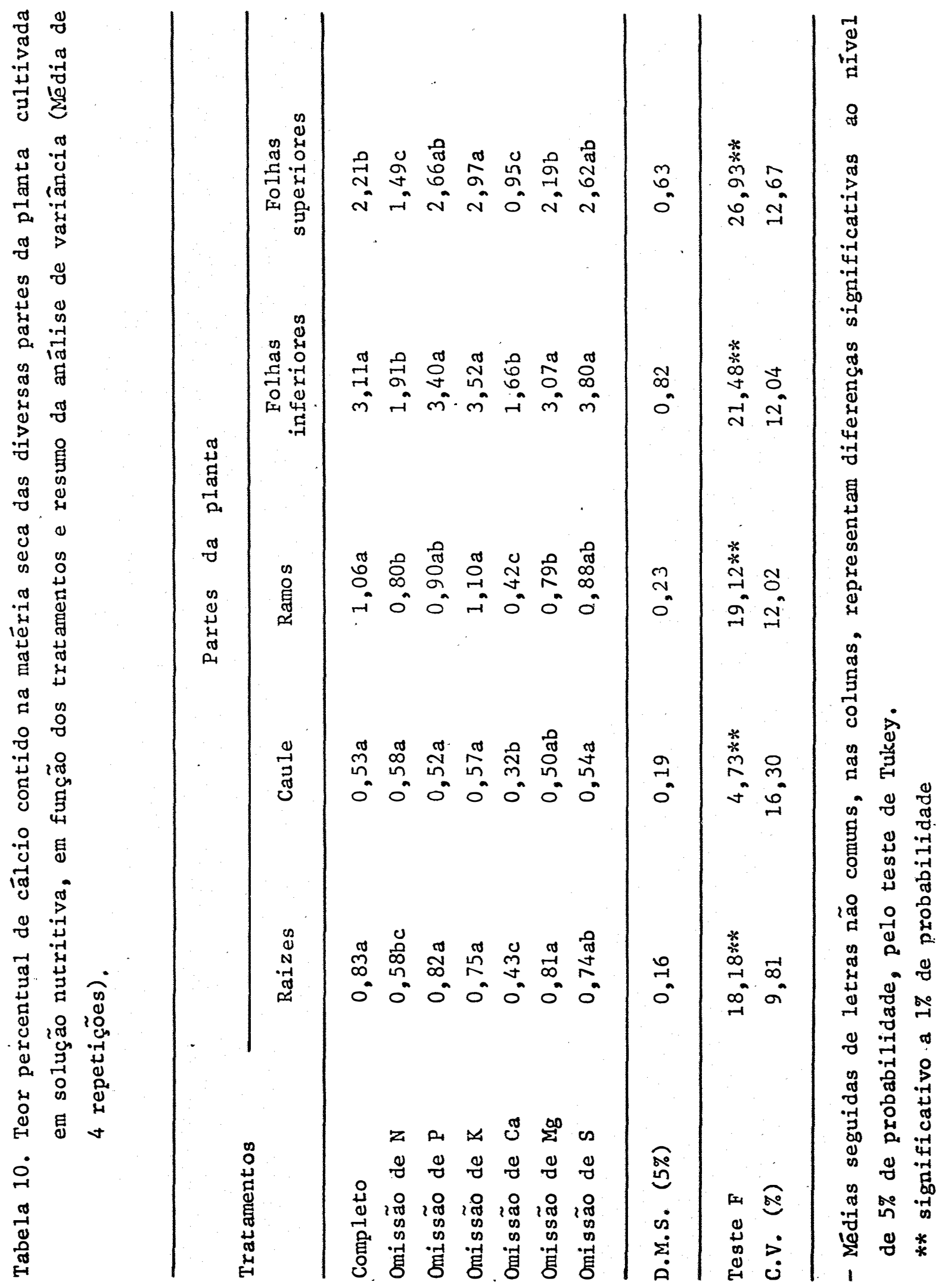


res significativamente mais baixos. que nos mesmos órgãos das plantas cultivadas em solução completa.

Omitindo potássio da solução a concentração de cälcio nas folhas superiores foi mais elevada em comparação com o tratamento completo.

Por outro 1 ado, com a omissão de magnésio da solução houve uma diferença expressiva no teor de cālcio nos ramos da planta em confronto com o tratamento completo.

Quanto as omisiões de fósforo e enxofre verifica-se que estas não afetaram a concentração de cälcio näs diversas partes da planta.

Segundo HOAGLAND (1948), a diminuição na absorção de um cátion será compensada peía absorção de outro, de maneira que o total de bases permanecerá constante, conduzindo a um equilíbrio no interior da planta. overstreEt et alii (1952) estudando aspectos do mecanismo de absorção de cálcio e potássio confirmam essa teoria, afirmando que a falta de um desses cátions resulta na maior absorção do outro.

4.1.3.5. Magnèsio

As concentrações médias de magnésio nas diversas partes da planta, bem como o resumo da anālise de variância acham-se na Tabe 1 a 11 .

Observa-se que houve uma redução na concentração de magnésio para todas as partes das plantas quando este 


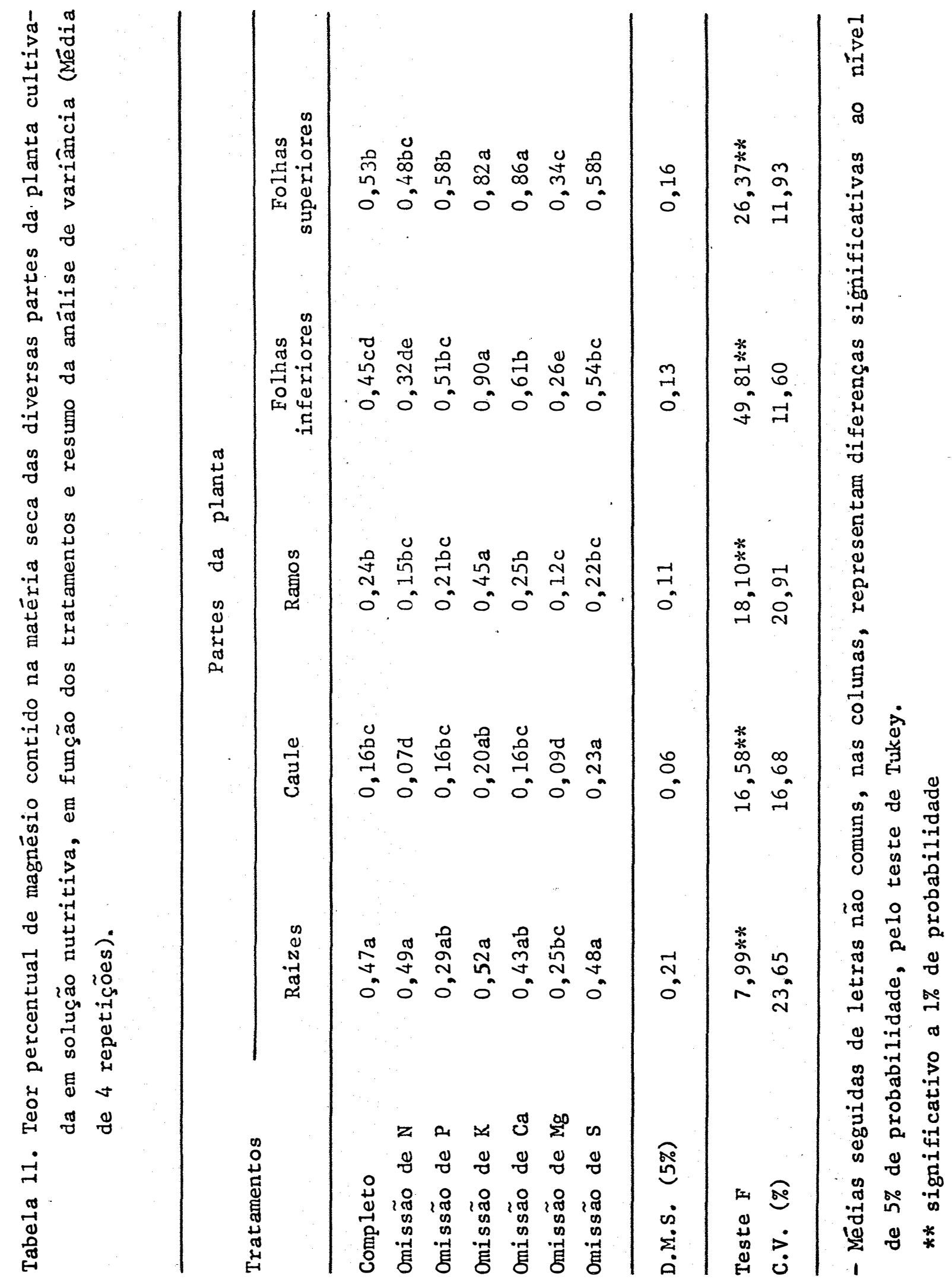


elemento foi omitido. Resultados semelhantes foram encontrados por AMARAL (1983) em seringueira.

Com a omissão do niţrogênio da solução nutritiva houve uma diminuição no teor de magnésio no caule, em comparação ao tratamento completo.

A omissão de fósforo e de enxofre da solução não influenciou a concentração de magnésio nos diferentes órgãos da planta.

Com a omissão de potássio da solução houve um aumento nas concentrações de magnésio nos ramos, folhas inferiores e superiores em comparação ao tiratamento completo, mos trando, segundo LUCAS e SCARSETH (1947) que pode ser uma evidência do papel deste cátion na absorção do magnésio. Vários autores jả observaram fenômeno idêntico, entre eles HAAG (1958) e MALAVOLTA (1963), que trabalharam com cafeeiro em so lução nutritiva e em condições de campo, respectivamente.

Com relação a omissão de cálcio, o mesmo efeito foi observado nas concentrações de magnésio para folhas in feriores e superiores sendo uma indicação do antagonismo exi $\underline{s}$ tente entre esses nutrientes, fato já constatado por inúmeros autores em vārias espécies.

$4 \cdot 1 \cdot 3 \cdot 6$. Enxofre

Na Tabela 12 encontram-se as concentrações médias de enxofre e os dados resumidos da análise de variância. observa-se que a omissão de enxofre causou re- 


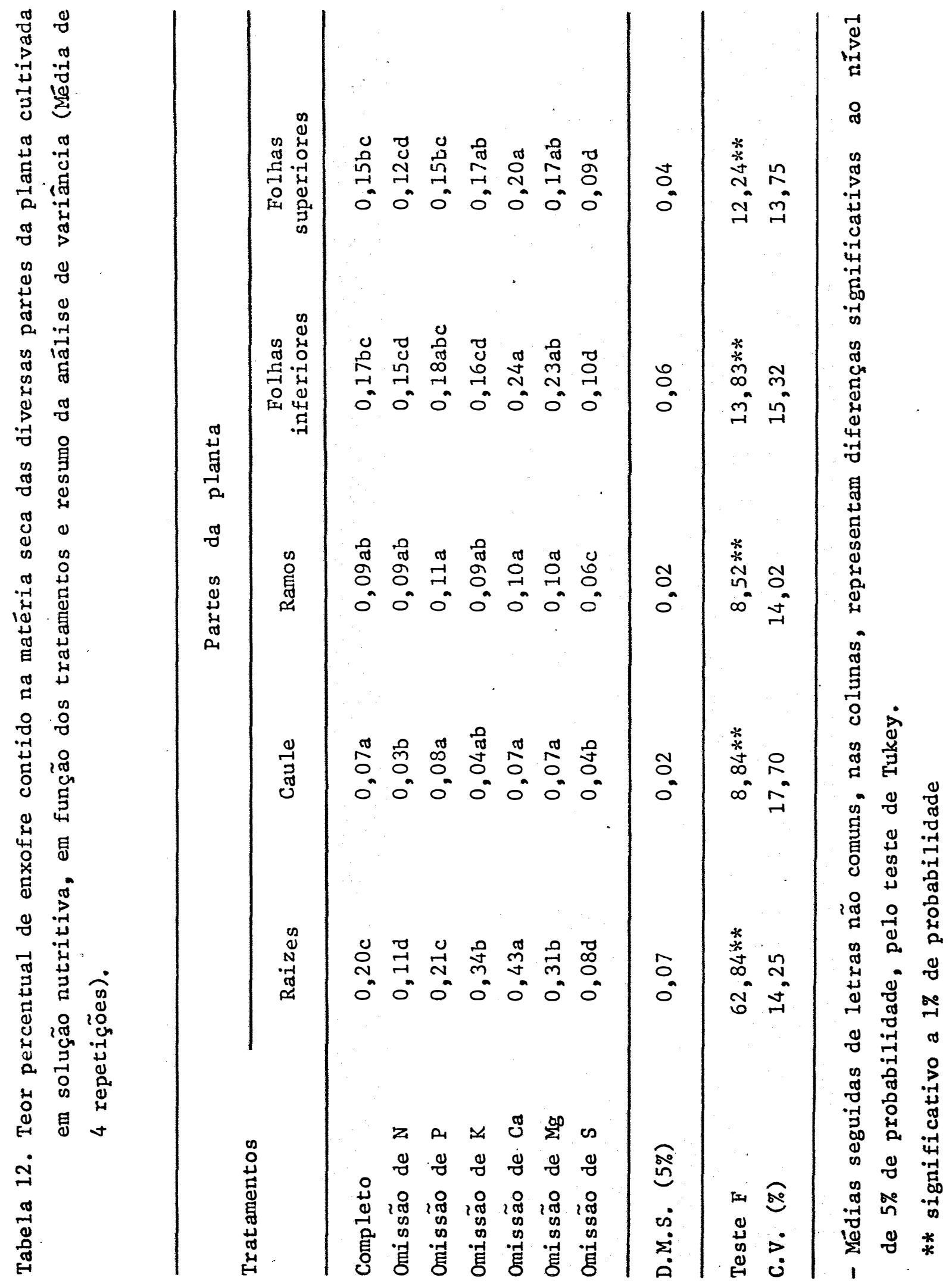


dução nos teores desse elemento nas diversas partes da planta, quando em confronto com o tratamento completo.

A omissāo de nitrogênio da solução nutritiva motivou uma diminuição nas concentraçōes de enxofre nas raíies e caule quando confrontados com a do tratamento completo. Segundo THOMAZ et alii (1950), a estreita relação entre o metabolismo do enxofre e do nitrogênio dentro das plantas, ba seia-se em grande parte, no fato de que os aminoácidos contendo enxofre são constituintes essenciais das proteínas da planta.

A Tabela 12 mostra qué a omissão de f́ósforo não influenciou a concentração de enxofre nos órgãos da planta. Por outro lado, os teores de enxofre nas raízes foram maio res quando se omitiu o potássio e magnésio da solução nutritiva.

Nota-se ainda na referida Tabela, que a omissão do cálcio provocou um aumento expressivo nos teores de en xofre nas raízes, folhas inferiores e superiores em relação ao tratamento com solução completa. MALAvolta (1977) cita que a absorção de enxofre depende diretamente de sua concentração e indiretamente das concentrações de cālcio e magnésio.

\section{$4 \cdot 1 \cdot 3.7$. Boro}

As médias das concentrações em pp̣̣ de boro nas diversas partes das plantas, e o resumo da anālise de variância podem ser observados na Tabela 13. 


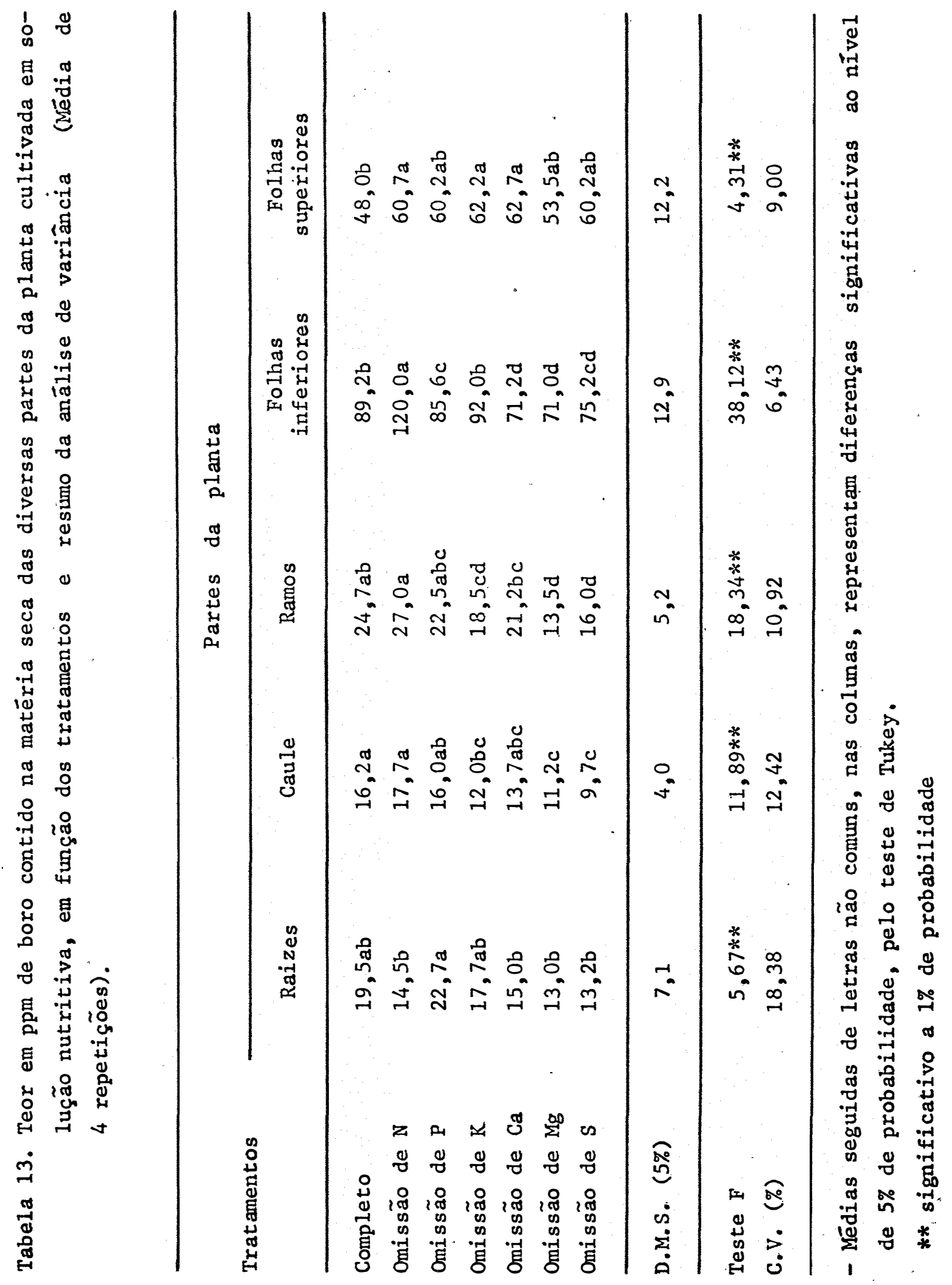


Verifica-se que omitindo o nitrogênio da solução nutritiva houve um aumento acentuado no teor de boro das folhas inferiores e superiores, apresentando valores elevados em relação ao tratamento completo.

A omissão do fósforo da solução não interferiu no teor de boro nas diversas partes da planta.

o potássio quandó omitido provocou uma redução nos teores de boro no caule e ramos e um acréscimo acentuado na concentração das folhas superiores.

Na Tabela 13 observa-se que omitindo o cālcio da solução nutritiva ocorreu uma diminuição no teor de boro nas folhas inferiores e um aumento nas folhas superiores.

SARRUGE (1968), trabalhando com cafeeiro, não encontrou efeito do cálcio na absorção do boro. Por outro lado, segundo JONES e SCARSETH (1944) e MUHR (1942), os resultados contraditórios que são encontrados sugerem que os efeitos do boro sobre o metabolismo do cálcio variam com a espécie estudada e as condições do trabalho experimental. REEVE e SHIVE (1944) estudando a relação potássio-boro na nutrição de plantas, constataram que a concentração de potássio do substrato tem uma influência definida sobre o acúmulo de boro nos tecidos.

Nessa mesma Tabela observa-se que omitindomag nésio e enxofre da solução houve um decréscimo na concentra ção de boro no caule, ramose folhas inferiores. 
$4 \cdot 1 \cdot 3 \cdot 8$. Cobre

Os valores médios dos teores em ppm de cobre nas partes das plantas, bem como o resumo da anälise de variância, encontram-se na Tabela 14 .

Observa-se que a omissäo do enxofre da solução nutritiva, provocou um decréscimo no teor de cobre no caule, folhas inferiores e folhas superiores em relação aos teores dos mesmos órgãos das plantas cultivadas em solução nutritiva completa.

Os teores de cobre nas diversas partes das plan tas não foram influenciadas quando se'omitiu nitrogênio, fósforo, potássio, cālcio e magnésio da solução nutritiva, em confronto com o tratamento completo.

\subsubsection{Ferro}

São apresentadas na Tabela 15 , os teores emppm de ferro nas diversas partes da planta e o resumo da anālise de. variância.

Analisando-se os dados contidos na referida tạ bela, verifica-se que a omis s̃ão do nitrogênio da solução nutritiva originou um aumento no teor de ferro do caule, em com paração ao tratamento completo.

As concentrações de ferro aumentaram significa tivamente em confronto com o tratamento completo nas diversas partes da planta quando se omitiu o cálcio. 


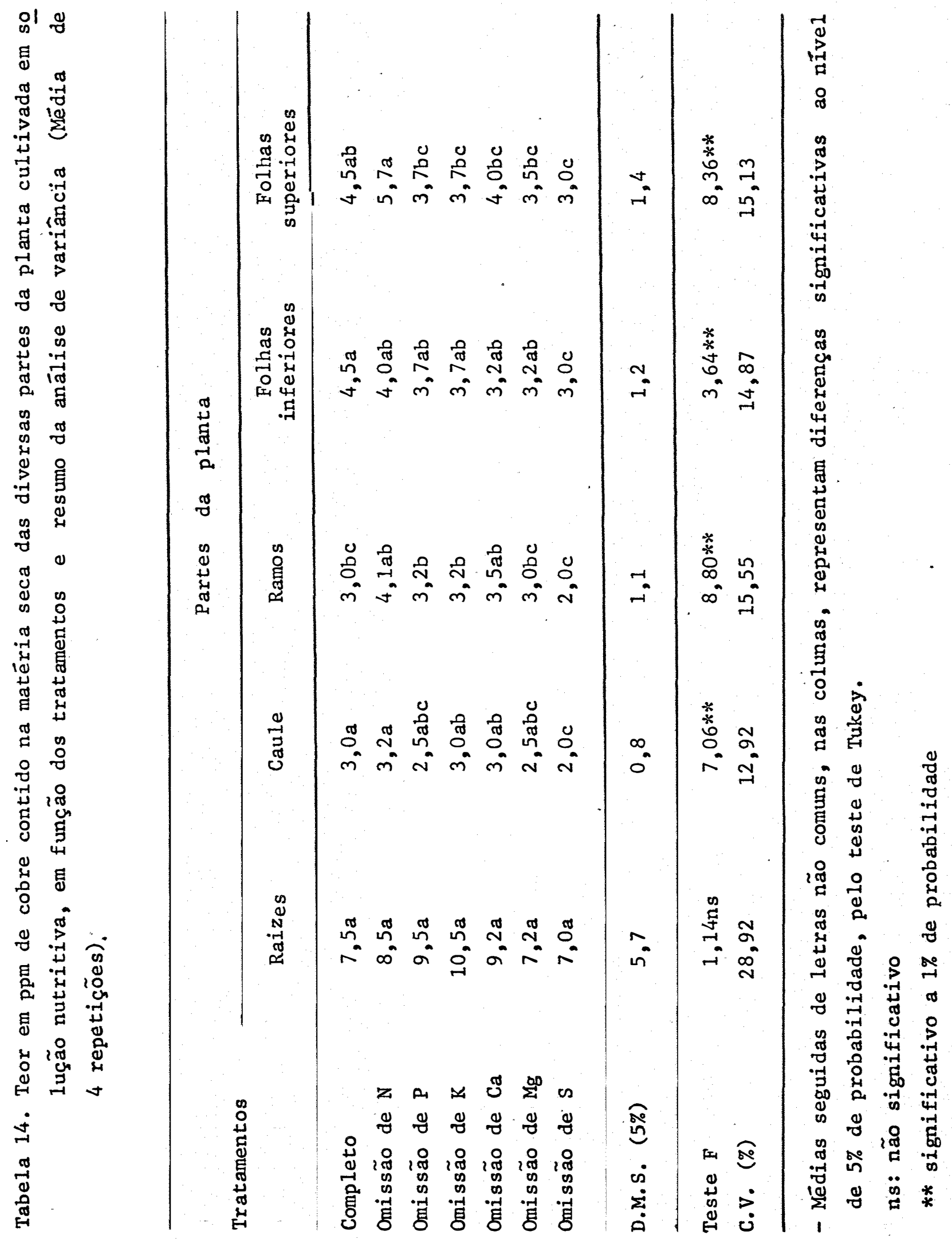




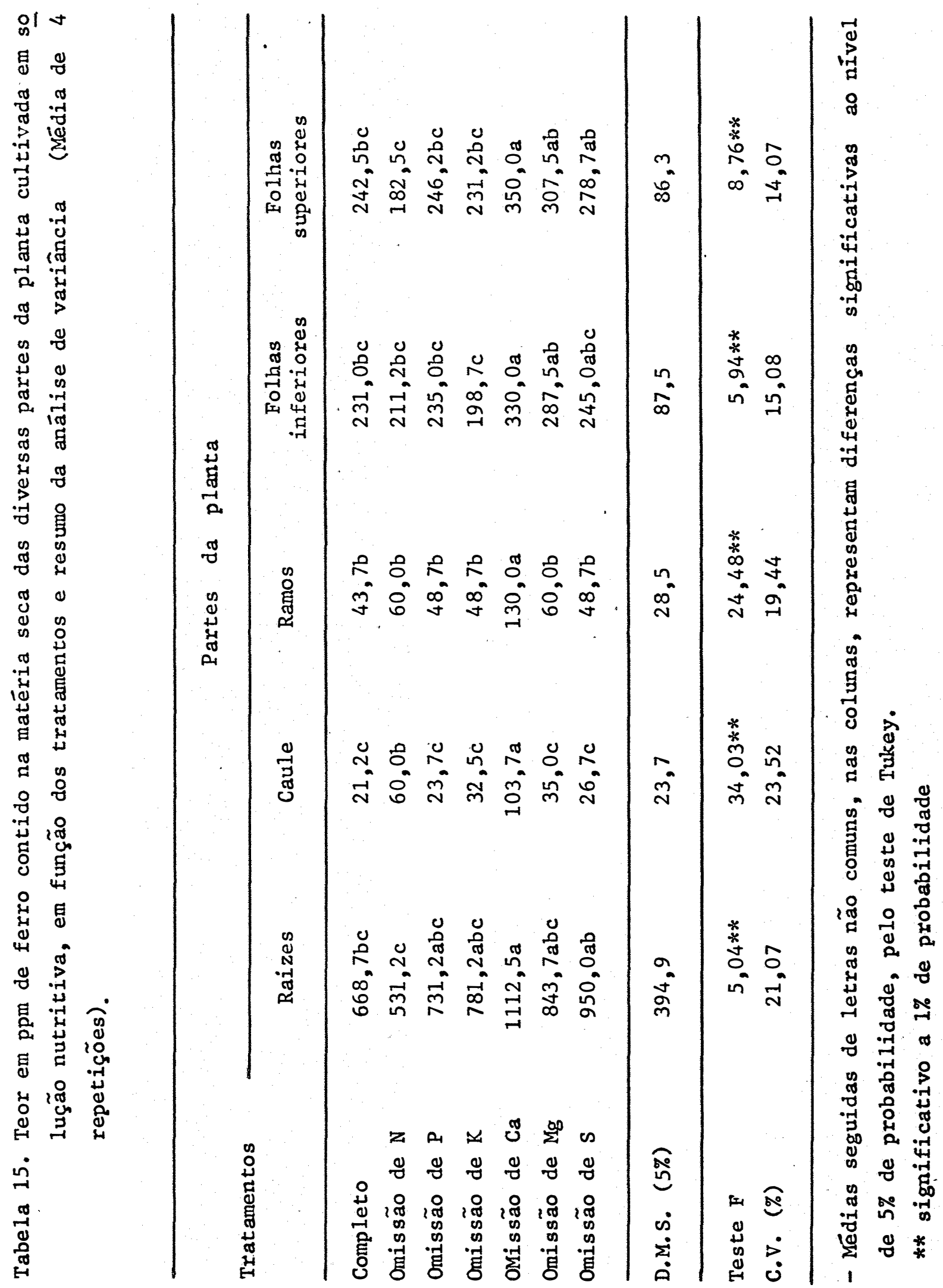


De acordo com MASCARENHAS (1977) é provävel que essa tendência em crescer o nível de ferro nos tratamen tos deficientes em nitrogênio e cảlcio, seja o resultado do antagonismo na absorção do ion ferro, o que reforça os resultados obtidos no presente ensaio.

Finalmente, pela Tabela 15, verifica-se que as omissões de fósforo, potássio, magnésio e enxofre da solução não mostraram diferenças nos teores de ferro nas diversas par tes da planta, em relação ao tratamento completo.

LINGLE et alii (1963) relatam que a absorção de ferro é extremamente influenciada pela competição de cātions como: $\mathrm{Mn}^{+2}, \mathrm{Cu}^{+2}, \mathrm{Ca}^{+2}, \mathrm{Mg}^{+2}, \mathrm{Zn}^{+2} \mathrm{e}^{+}$.

4.1.3.10. Manganês

Os valores médios dos teores em ppm dé manganês nas partes das plantas e o resumo da anảlise de variância encontram-se na Tabela 16 .

Omitindo nitrogênio da solução, houve um aumen to significativo no teor de manganês nas folhas inferiores. En tretanto, quando se omitiu fósforo e enxofre da solução não houve influência na concentração do manganês nos diferentesór gãos da planta.

Verifica-se na Tabela 16 , que no tratamento on de se omitiu o potássio originou. um aumento na. concentração de manganês na raiz e folhas inferiores. Com a omissão do cál cio, houve um aumento no teor de manganês na raiz, ramos, fo- 


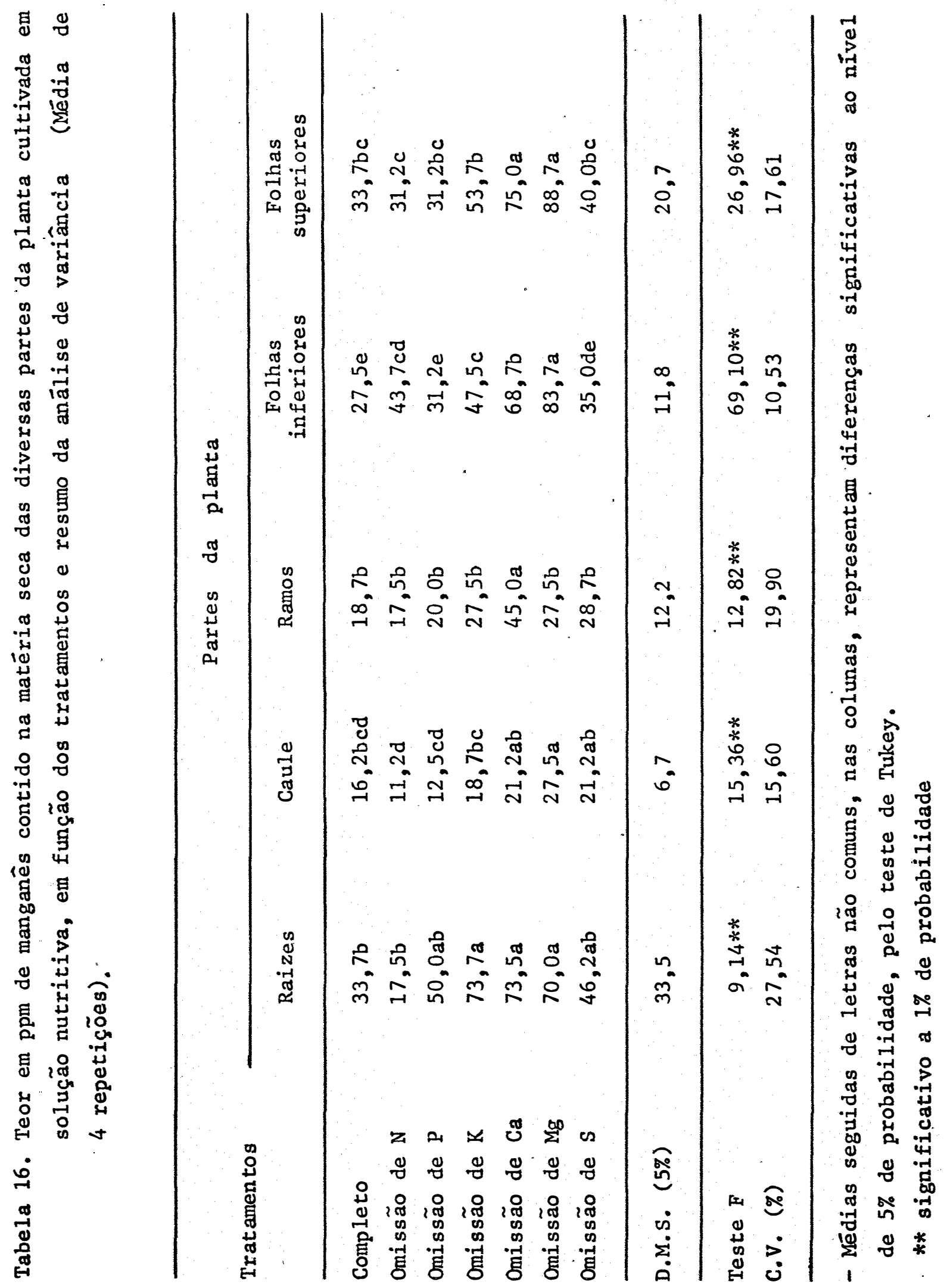


lhas inferiores e superiores, enquanto que omitindo o magnésio este aumento se verificou na raiz, caule, folhas inferiores e superiores, sendo todos eles superiores quando comparados ao tratamento completo. Estes efeitos já foram observados por AMARAL (1983) e SHORROCKS (1965) em seringueira.

Por outro lado, autores como LOHnIS (1960) e MASS et alii (1969) relatam que hä um efeito competitivo entre o manganês e cátions como cálcio e o magnésio.

$$
\begin{aligned}
& 4.1 .3 .11 . \text { Zinco } \\
& \text { Os teores em ppm de zinco nas diversas partes }
\end{aligned}
$$

da planta e o resumo da análise de variância acham-se na Tabe 1 a 17 .

Pelos dados observa-se que a omissão de quais quer dos nutrientes estudados, não afetou a concentração de zinco nas diversas partes da planta quando comparados com o tratamento completo.

4.1.4. Níveis de nutrientes

Os teores médios dos macronutrientes contidos nas diversas partes das plantas em função dos tratamentos com pleto e com omissão de nutrientes são apresentados na Tabela 18 . 


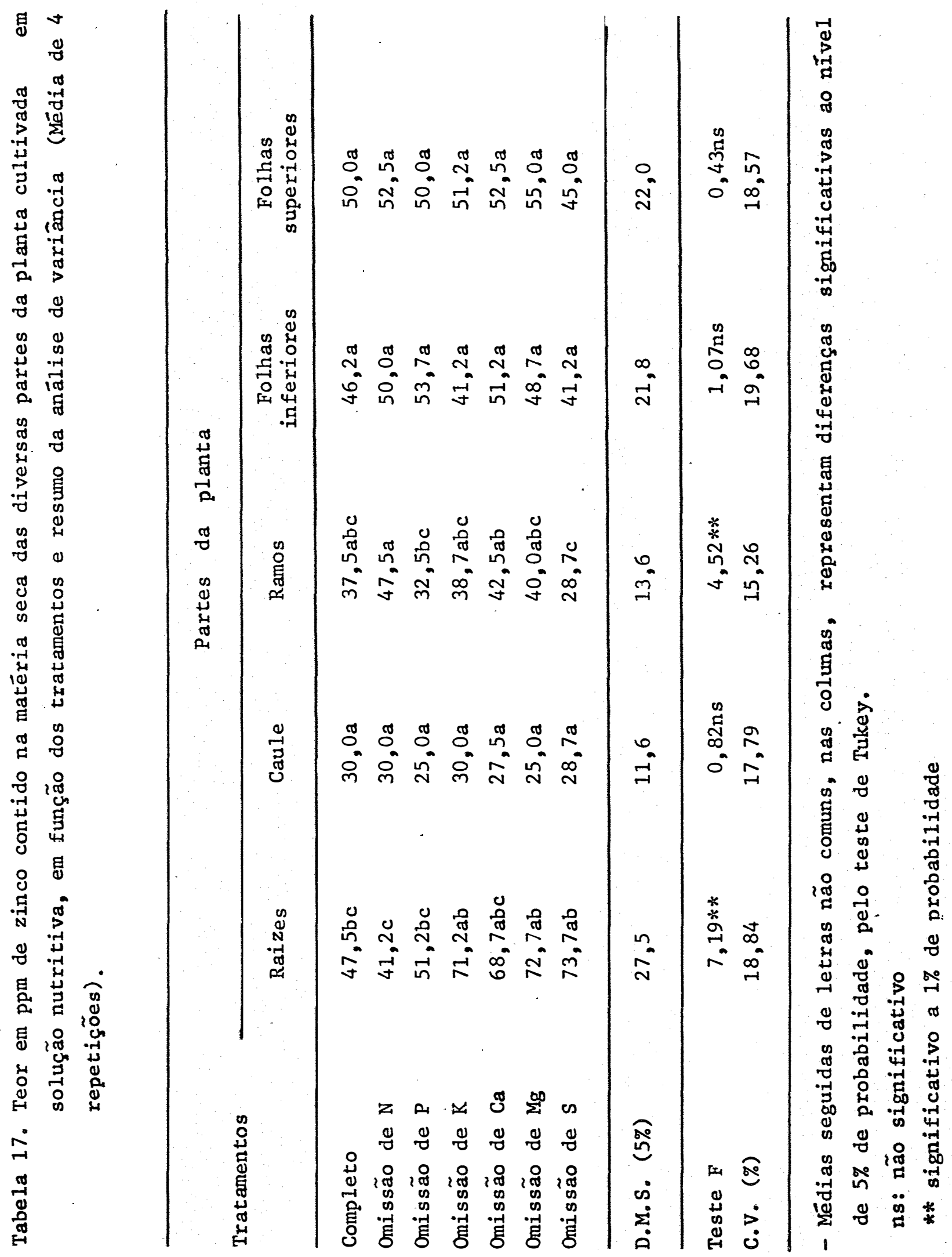


Tabela 18. Teores médios de macronutrientes contidos nas diversas partes da planta em função dos tratamentos completo e com omissão de nutrientes.

\begin{tabular}{llcccc}
\hline Nutrientes & Raizes & Caule & Ramos & $\begin{array}{c}\text { Folhas } \\
\text { inferiores superiores }\end{array}$ \\
\hline N Completo & 1,95 & 0,91 & 1,21 & 1,47 & 1,63 \\
Deficiente & 0,94 & 0,53 & 0,66 & 0,88 & 1,03 \\
P Completo & 0,15 & 0,18 & 0,28 & 0,15 & 0,19 \\
Deficiente & 0,10 & 0,07 & 0,13 & 0,04 & 0,08 \\
K Completo & 0,79 & 0,64 & 0,81 & 1,04 & 1,32 \\
Deficiente & 0,32 & 0,40 & 0,36 & 0,07 & 0,33 \\
Ca Completo & 0,83 & 0,53 & 1,06 & 3,11 & 2,21 \\
Deficiente & 0,43 & 0,32 & 0,42 & 1,66 & 0,95 \\
Mg Completo & 0,47 & 0,16 & 0,24 & 0,45 & 0,53 \\
Deficiente & 0,25 & 0,09 & 0,12 & 0,26 & 0,34 \\
S Completo & 0,20 & 0,07 & 0,09 & 0,17 & 0,15 \\
Deficiente & 0,08 & 0,04 & 0,06 & 0,11 & 0,09 \\
\hline
\end{tabular}

Tabela 19. Teores médios de micronutrientes contidos nas diversas partes da planta relativo ao tratamento completo.

\begin{tabular}{crrrrr}
\hline Nutrientes & Raizes & Caule & Ramos & $\begin{array}{c}\text { Folhas } \\
\text { inferiores superiores }\end{array}$ \\
\hline B & 19,5 & 16,2 & 24,7 & 89,2 & 48,0 \\
Cu & 7,5 & 3,0 & 3,0 & 4,5 & 5,7 \\
Fe & 668,7 & 21,2 & 43,7 & 231,0 & 242,5 \\
Mn & 33,7 & 16,2 & 18,7 & 27,5 & 33,7 \\
Zn & 47,5 & 30,0 & 37,5 & 46,2 & 50,0 \\
\hline
\end{tabular}


Os teores médios de micronutrientes nas diversas partes das plantas relativos ao tratamento completo expressos em partes por milhão acham-se na Tabela 19.

\subsection{Experimento em campo}

4.2.1. Desenvolvimento das plantas

O desenvolvimento das plantas foi avaliadoatra vés dos dados de altura das plantas, diâmetro do, caule (DAP) e produção de matéria seca total e das diversas partes da planta.

$$
\begin{aligned}
& \text { 4.2.1.1. Altura das plantas e diâmetro do } \\
& \text { caule }
\end{aligned}
$$

As médias da altura das plantas e do diâmetro médio dos caules em função das diferentes idades e o resumoda análise de variância encontram-se na Tabela 20 , enquanto que as equações de regressão, acham-se na Tabela 21.

Analisando os dados de altura das plantas e do diâmetro dos caules, verifica-se como era de se esperar que hou ve diferenças acentuadas em função das idades com relação a estas variáveis.

Para ambos os parâmetros ajustaram-se regressões lineares, com altos coeficientes de determinação onde os 
Tabela 20. Altura das plantas (m) e diâmetro (DAP) do caule $(\mathrm{cm})$, em função das idades (Média de 5 repetições).

\begin{tabular}{lcc}
\hline $\begin{array}{l}\text { Idades } \\
\text { (meses) }\end{array}$ & $\begin{array}{c}\text { Altura das plantas } \\
(\mathrm{m})\end{array}$ & $\begin{array}{c}\text { Diâmetro do caule (DAP) } \\
(\mathrm{cm})\end{array}$ \\
\hline 24 & $2,91 \mathrm{~d}$ & $4,44 \mathrm{~d}$ \\
36 & $3,70 \mathrm{c}$ & $6,35 \mathrm{c}$ \\
48 & $5,02 \mathrm{~b}$ & $9,30 \mathrm{~b}$ \\
96 & $12,35 \mathrm{a}$ & $17,75 \mathrm{a}$ \\
\hline DMS (Tukey 5\%) & 0,72 & 1,62 \\
\hline Teste F & $597,40 * *$ & $214,50 * *$ \\
C.V. (\%) & 6,60 & 9,48 \\
\hline
\end{tabular}

*** significativo a $1 \%$ de probabilidade

Tabela 21. Equações de regressão, coeficientes de determinação $\left(R^{2}\right)$, para altura média das plantas (m) e diâmetro (DAP) médio do caule (cm), em função das idades (meses).

Parâmetro

$$
\begin{gathered}
\text { Equação } \\
y=
\end{gathered}
$$

Altura das plantas

Diâmetro do caule

$-0,9453+0,1361 x$

$98,59 * *$

$-0,0205+0,1859 x$

$\mathrm{x}=$ representa a idade da planta em meses

$\mathrm{y}=$ representa a estimativa da altura das plantas e diâmetro do caule em funçẫo das idades.

$* *$ significativo a $1 \%$ de probabilidade 
valores de altura das plantas e diâmetro dos caules aumentavam com a idade das plantas. Aos 96 meses de idade a altura estimada das plantas foi de $12,12 \mathrm{~m}$ e do diâmetro do caule de $17,82 \mathrm{~cm}$.

\subsubsection{Produção de matéria seca}

Na Tabela 22 encontram-se as médias da produção de matéria seca das diversas partes e da planta inteira e resumo da análise de variância em função das idades, enquanto que as equações de regressão, coeficientes de determinação e pontos de mínimo são apresentados na Tabela 23 .

Observa-se pela Tabela 22 que houve diferenças na produção de matéria seca nas diferentes partes, e na planta inteira, em função das idades.

Os acúmulos de matéria seca nas folhas, ponta, meio e base do caule, assim como para planta inteira, ajustaram se a equações de regressão quadrāticas apresentando acúmulos mínimos de $1505,28 \mathrm{~g}$ aos 13 meses de idade para folhas; 363,93 $g$ aos 23 meses para ponta do caule; $681,80 \mathrm{~g}$ aos 22 meses para meio do caule; 945,32 g aos 21 meses para a base do caule e $6624,36 \mathrm{~g}$ aos 19 meses de idade para planta inteira (Tabela 23).

Na Tabela 23 verifica-se ainda que o acúmulo de matéria seca nos ramos também foi crescente, aumentando li nearmente com a idade das plantas. 
Tabela 22. Peso da matéria seca ( $\mathrm{g} / \mathrm{p}$ lanta) acumulada nas diversas partes e na planta inteira em função das idades (Média de 5 repetiçôes).

\begin{tabular}{|c|c|c|c|c|c|c|}
\hline \multirow{2}{*}{$\begin{array}{c}\text { Idade } \\
\text { (meses) }\end{array}$} & \multirow{2}{*}{ Folhas } & \multirow{2}{*}{ Ramos } & \multicolumn{3}{|c|}{ Caule } & \multirow{2}{*}{ Total } \\
\hline & & & Ponta & Meio & Base & \\
\hline $\begin{array}{l}24 \\
36 \\
48 \\
96\end{array}$ & $\begin{array}{r}1767,72 \mathrm{c} \\
1908,54 \mathrm{c} \\
3242,30 \mathrm{~b} \\
10387,71 \mathrm{a}\end{array}$ & $\begin{array}{r}2070,86 \mathrm{~b} \\
7692,56 \mathrm{~b} \\
5013,92 \mathrm{~b} \\
23229,60 \mathrm{a}\end{array}$ & $\begin{array}{c}439,68 c \\
817,42 b c \\
2698,99 b \\
19017,58 a\end{array}$ & $\begin{array}{r}853,59 c \\
1480,61 c \\
4884,04 b \\
32899,89 a\end{array}$ & $\begin{array}{r}1220,92 c \\
2190,12 c \\
7062,50 b \\
46201,82 a\end{array}$ & $\begin{array}{c}6352,77 \mathrm{c} \\
14089,25 \mathrm{bc} \\
22901,77 \mathrm{~b} \\
131736,60 \mathrm{a}\end{array}$ \\
\hline $\operatorname{DMS}(5 \%)$ & 805,93 & 6006,49 & 2127,59 & 2996,95 & 4647,90 & 10654,60 \\
\hline $\begin{array}{l}\text { Teste F } \\
\text { C.V. (\%) }\end{array}$ & $\begin{array}{c}423,46 * * \\
10,28\end{array}$ & $\begin{array}{l}40,47 * * \\
34,90\end{array}$ & $\begin{array}{c}287,30 * * \\
20,45\end{array}$ & $\begin{array}{c}430,26 * * \\
16,49\end{array}$ & $\begin{array}{c}351,22 * * \\
18,11\end{array}$ & $\begin{array}{c}503,52 * * \\
13,43\end{array}$ \\
\hline
\end{tabular}

*

Tabela 23. Equações de regressão, coeficientes de determinação $\left(R^{2}\right)$, pontos de mínimo ( $\mathrm{Pm}$ ) das quantidades de matéria seca ( $\mathrm{g} / \mathrm{planta),}$ acumuladas nas diversas partes e na planta inteira em função das idades.

\begin{tabular}{lccccc}
\hline $\begin{array}{l}\text { Partes da } \\
\text { planta }\end{array}$ & $\begin{array}{c}\text { Equações } \\
\mathrm{y}=\end{array}$ & & \multicolumn{2}{c}{ Ponto de mínimo } \\
\cline { 3 - 6 } & & & $\mathrm{R}^{2}$ & $\mathrm{x}$ & $\mathrm{y}$ \\
\hline Folhas & $1733,0212-34,3944 x+1,2986 \mathrm{x}^{2}$ & $99,77 * *$ & 13 & 1505,28 \\
Ramos & $-5159,71+287,48 x$ & $92,45 * *$ & - & - \\
Caule-ponta & $2139,0911-156,8883 x+3,4664 x^{2}$ & $99,97 * *$ & 23 & 363,93 \\
Caule-meio & $3529,0906-258,9021 x+5,8854 x^{2}$ & $99,96 * *$ & 22 & 681,80 \\
Caule-base & $4610,1996-344,7205 x+8,1061 x^{2}$ & $99,96 * *$ & 21 & 945,32 \\
\hline Total & $14793,9988-836,0699 x+21,3906 x^{2}$ & $99,95 * *$ & 19 & 6624,36 \\
\hline
\end{tabular}

$\mathrm{x}=$ representa $\mathrm{a}$ idade da planta em meses

$\mathrm{y}=$ representa a estimativa do peso da matéria seca, em gramas/planta

** significativo a $1 \%$ de probabilidade 
Aos 24 e 96 meses de idade a produção de materia seca estimada foi de 1655,54 e 10398,00 g/planta para fo1has, 1739,70 e 2243,80 g/planta para ramos; 370,43 e 19024,00 g/planta para ponta do caule; 705,45 e 32914,00 g/planta para meio do caule;1006,00 e 46223,00 g/planta para base do caule e 7049,20 e 131667,05 g/planta para planta inteira.

\subsubsection{Macronutrientes}

4.2.2.1. Nitrogênio

a) Concentração

Os resultados analíticos referentes à concentração de nitrogênio nas diversas partes da planta, em função das idades, são apresentados nas Tabelas 24 e 25 .

Constata-se que as concentrações de nitrogênio nas diversas partes da planta diminuem com a idade (Tabe1a 24), sendo estas diferenças mais efetivas quando se compa= ra os teores aos 24 e aos 96 meses de idade, exceção feita pạ ra base do caule. Por outro lado, verifica-se que as maiores concentrações do elemento foram encontradas nas folhas.

Pela Tabela 25 observa-se que ajustou-se regressões quadráticas para as concentrações de nitrogênio em função das idades em todas as partes da planta, com mínimos de $2,28 \%$ aos 64 meses de idade para folhas; $0,51 \%$ aos 64 meses para ramos; $0,35 \%$ aos 67 meses para ponta do caule, 
Tabela 24. Teor percentual de nitrogênio (\%) contido na matéria seca das diversas partes da planta em função dasidades (Média de 5 repetições).

\begin{tabular}{cccccc}
\hline & & & \multicolumn{3}{c}{ Caule } \\
\cline { 4 - 6 } (meses) & Folhas & Ramos & Ponta & Meio & Base \\
\cline { 4 - 6 } & & & & & \\
\hline 24 & $2,73 \mathrm{a}$ & $0,95 \mathrm{a}$ & $0,80 \mathrm{a}$ & $0,75 \mathrm{a}$ & $0,68 \mathrm{a}$ \\
36 & $2,71 \mathrm{a}$ & $0,74 \mathrm{ab}$ & $0,51 \mathrm{~b}$ & $0,53 \mathrm{~b}$ & $0,60 \mathrm{ab}$ \\
48 & $2,61 \mathrm{a}$ & $0,58 \mathrm{~b}$ & $0,47 \mathrm{~b}$ & $0,44 \mathrm{~b}$ & $0,46 \mathrm{~b}$ \\
96 & $2,25 \mathrm{~b}$ & $0,76 \mathrm{~b}$ & $0,53 \mathrm{~b}$ & $0,51 \mathrm{~b}$ & $0,55 \mathrm{ab}$ \\
\hline DMS (5\%) & 0,36 & 0,20 & 0,13 & 0,09 & 0,16 \\
\hline Teste F & $6,13 * *$ & $8,74 * *$ & $20,33 * *$ & $34,63 * *$ & $5,53 * *$ \\
C.V. (\%) & 7,81 & 14,79 & 12,80 & 9,00 & 15,32 \\
\hline
\end{tabular}

** significativo a $1 \%$ de probabilidade

Tabela 25. Equações de regressão, coeficientes de determinação ( $\left.\mathrm{R}^{2}\right)$, pontos de mínimo $(\mathrm{Pm})$ do teor percentual de nitrogênio $(\%=y)$ nas diversas partes da planta em função das idades (meses = $\mathrm{x})$.

\begin{tabular}{lllll}
$\begin{array}{l}\text { Partes } \\
\text { da planta }\end{array}$ & \multicolumn{1}{c}{$\begin{array}{c}\text { Equações } \\
\mathrm{y}=\end{array}$} & $\mathrm{R}^{2}$ & \multicolumn{2}{c}{ Ponto de mínimo } \\
\cline { 5 - 6 } & & & $\mathrm{x}$ & $\mathbf{y}$ \\
\hline Folhas & $3,6271-0,0421 x+0,0003 \mathrm{x}^{2}$ & $65,07 * *$ & 64 & 2,28 \\
Ramos & $1,6183-0,0339 x+0,0002 x^{2}$ & $92,10 * *$ & 64 & 0,51 \\
Caule-ponta & $1,3237-0,0305 x+0,0002 x^{2}$ & $91,84 * *$ & 67 & 0,35 \\
Caule-meio & $1,2967-0,0279 x+0,0002 x^{2}$ & $97,94 * *$ & 67 & 0,35 \\
Caule-base & $1,0870-0,0196 x+0,0001 x^{2}$ & $93,67 * *$ & 66 & 0,43
\end{tabular}

** significativo a $1 \%$ de probabilidade 
$0,35 \%$ aos 67 meses para meio do caule e $0,43 \%$ aos 66 meses de idade para base do caule.

Aos 24 e 96 meses de idade, as folhas apresentaram concentrações estimadas de $2,80 \%$ e $2,61 \%$; ramos $0,95 \%$ e $0,77 \%$; ponta do caule $0,78 \%$ e $0,53 \%$; meio do caule $0,74 \%$ e $0,52 \%$ e base do caule $0,70 \%$ e $0,56 \%$. No ensaio de casa de vegetação, com solução nutritiva, obteve-se os seguintes teores de nitrogênio para plantas submetidas a tratamento com omissão do elemento: folhas superiores $1,03 \%$; folhas inferiores $0,88 \%$; ramos $0,66 \%$ e caule $0,53 \%$. Observa-se que os teores encontrados nas plantas com 24 e 96 meses de idade estão acima dos limites verificados em plantas carentes.

b) Acūmu 10

Os resultados analiticos obtidos sobre o acumulo de nitrogênio nas diversas partes da planta, em função das idades, acham-se nas Tabelas 26 e 27.

Verifica-se pela Tabela 26 que houve efeitodas idades nas quantidades de nitrogênio acumuladas pelas partes e para planta inteira. Observa-se que embora não tenha havido diferenças marcantes no acưmulo do elemento nas primeiras ida des, este aumento foi gradativo associado à produção da matéria seca, sendo esta diferença expressiva aos 96 meses de ida de .

As quantidades de nitrogênio acumuladas nas partes e na planta inteira obedeceram equações de regressão 
Tabela 26. Quantidades de nitrogênio (g) acumuladas nas diversas partes da planta em função das idades (Média de 5 repetições).

\begin{tabular}{|c|c|c|c|c|c|c|}
\hline \multirow{2}{*}{$\begin{array}{l}\text { Idade } \\
\text { (meses) }\end{array}$} & \multirow{2}{*}{ Folhas } & \multirow{2}{*}{ Ramos } & \multicolumn{3}{|c|}{ Caule } & \multirow{2}{*}{ Total } \\
\hline & & & Ponta & Meio & Base & \\
\hline $\begin{array}{l}24 \\
36 \\
48 \\
96\end{array}$ & $\begin{array}{r}48,26 \mathrm{~b} \\
51,93 \mathrm{~b} \\
73,15 \mathrm{~b} \\
272,94 \mathrm{a}\end{array}$ & $\begin{array}{r}19,86 \mathrm{~b} \\
28,52 \mathrm{~b} \\
56,11 \mathrm{~b} \\
177,83 \mathrm{a}\end{array}$ & $\begin{array}{r}3,53 b \\
4,29 b \\
12,91 b \\
100,55 a\end{array}$ & $\begin{array}{r}6,44 c \\
7,85 c \\
21,94 b \\
168,86 a\end{array}$ & $\begin{array}{r}8,33 b \\
13,33 b \\
32,68 b \\
261,63 a\end{array}$ & $\begin{array}{c}86,42 \mathrm{c} \\
133,51 \mathrm{bc} \\
169,20 \mathrm{~b} \\
981,81 \mathrm{a}\end{array}$ \\
\hline DMS (5\%) & 40,50 & 44,38 & 14,37 & 8,29 & 62,48 & 70,41 \\
\hline $\begin{array}{l}\text { Teste } \mathrm{F} \\
\text { C.V. (\%) }\end{array}$ & $\begin{array}{c}116,88 * * \\
20,04\end{array}$ & $\begin{array}{l}44,54 * * \\
34,72\end{array}$ & $\begin{array}{c}175,55 * * \\
26,16\end{array}$ & $\begin{array}{c}75,23 * * \\
8,93\end{array}$ & $\begin{array}{l}62,74 * * \\
43,67\end{array}$ & $\begin{array}{c}604,28 * * \\
11,34\end{array}$ \\
\hline
\end{tabular}

** significativo a $1 \%$ de probabilidade

Tabela 27. Equações de regressão, coeficientes de determinação $\left(\mathrm{R}^{2}\right)$, pontos de mínimo ( $\mathrm{Pm}$ ) das quantidades de nitrogênio ( $\mathrm{g}=\mathrm{y}$ ) acumula das nas diversas partes da planta em função das idades (meses $\overline{=}$ $\mathrm{x}$.

\begin{tabular}{|c|c|c|c|c|}
\hline \multirow{2}{*}{$\begin{array}{l}\text { Partes } \\
\text { da planta }\end{array}$} & \multirow{2}{*}{$\begin{array}{c}\text { Equações } \\
y=\end{array}$} & \multirow{2}{*}{$\mathrm{R}^{2}$} & \multicolumn{2}{|c|}{ Ponto de mínimo } \\
\hline & & & $\mathrm{x}$ & $\mathrm{y}$ \\
\hline $\begin{array}{l}\text { Folhas } \\
\text { Ramos } \\
\text { Caule-ponta } \\
\text { Caule-meio } \\
\text { Caule-base }\end{array}$ & $\begin{array}{l}73,6226-2,1383 x+0,0439 x^{2} \\
51,5343-1,6417 x+0,0307 x_{2}^{2} \\
17,2222-1,0655 x+0,0201 x_{2}^{2} \\
29,7385-1,7994 x+0,0338 x^{2} \\
44,0297-2,7339 x+0,0521 x^{2}\end{array}$ & $\begin{array}{l}99,98 * * \\
94,43 * * \\
99,98 * * \\
99,98 * * \\
99,99 * *\end{array}$ & $\begin{array}{l}25 \\
27 \\
26 \\
26 \\
26\end{array}$ & $\begin{array}{r}47,59 \\
29,58 \\
3,13 \\
5,82 \\
8,15\end{array}$ \\
\hline Total & $216,1474-9,3789 x+0,1807 x^{2}$ & $99,87 * *$ & 26 & 94,44 \\
\hline
\end{tabular}

** significativo a $1 \%$ de probabilidade 
quadräticas com mínimos de $47,59 \mathrm{~g}$ aos 25 meses de idade para folhas; $29,58 \mathrm{~g}$ aos 27 meses para ramos; $3,13 \mathrm{~g}$ aos 26 meses para ponta do caule; $5,82 \mathrm{~g}$ aos 26 meses para meio do caule; $8,15 \mathrm{~g}$ aos 26 meses para base do caule e $94,44 \mathrm{~g}$ aos 26 meses de idade para planta inteira (Tabela 27).

Aos 24 meses de idade encontrou-se acúmulo estimado de $28,05 \mathrm{~g}$ de $\mathrm{N} / \mathrm{kg}$ de folhas; $9,54 \mathrm{~g}$ de N/kg de ramos; $7,81 \mathrm{~g}$ de $\mathrm{N} / \mathrm{kg}$ de ponta do caule; $7,44 \mathrm{~g}$ de $\mathrm{N} / \mathrm{kg}$ de meio, do caule e 7,00 g de $\mathrm{N} / \mathrm{kg}$ de base do caule. Para plantas com 96 meses de idade a estimativa foi de $26,10 \mathrm{~g}$ de $\mathrm{N} / \mathrm{kg}$ de folhas; $7,70 \mathrm{~g}$ de $\mathrm{N} / \mathrm{kg}$ de ramos; $5,34 \mathrm{~g}$ de $\mathrm{N} / \mathrm{kg}$ de ponta do caule; $5,20 \mathrm{~g}$ de $\mathrm{N} / \mathrm{kg}$ de meio do caule e 5,60 de $\mathrm{N} / \mathrm{kg}$ de base do cau1 e.

As plantas com 24 e 96 meses de idade mostraram acūmulos estimados de nitrogênio (g/planta) em 47,59 e $273,00 \mathrm{~g}$ para folhas; 29,81 e $176,83 \mathrm{~g}$ para ramos; 3,25 e $100,58 \mathrm{~g}$ para ponta do caule; 6,04 e $168,90 \mathrm{~g}$ para meio do. caule e 95,12 e 980,93 g para planta inteira.

\subsubsection{Fósforo}

\section{a) Concentração}

os valores de concentração de fósforo nas diversas partes da planta, em função das idades, resumo da ana lise de variância e as equações de regressão, coeficientes de determinação e pontos de máximo acham-se expostos nas Tabelas 28 e 29 . 
Tabela 28. Teor percentual de fósforo (\%) contido na matéria seca das diversas partes da planta em função das idades (Média de 5 repetiçôes).

\begin{tabular}{|c|c|c|c|c|c|}
\hline \multirow{2}{*}{$\begin{array}{c}\text { Idade } \\
\text { (meses) }\end{array}$} & \multirow{2}{*}{ Folhas } & \multirow{2}{*}{ Ramos } & \multicolumn{3}{|c|}{ Caule } \\
\hline & & & Ponta & Meio & Base \\
\hline $\begin{array}{l}24 \\
36 \\
48 \\
96\end{array}$ & $\begin{array}{l}0,10 a \\
0,13 a \\
0,11 a \\
0,10 a\end{array}$ & $\begin{array}{l}0,05 b \\
0,06 b \\
0,09 a \\
0,05 b\end{array}$ & $\begin{array}{l}0,04 b \\
0,06 a \\
0,07 a \\
0,03 b\end{array}$ & $\begin{array}{l}0,04 \mathrm{a} \\
0,04 \mathrm{a} \\
0,03 \mathrm{ab} \\
0,02 \mathrm{~b}\end{array}$ & $\begin{array}{l}0,04 a \\
0,04 a \\
0,04 a \\
0,02 b\end{array}$ \\
\hline DMS (5\%) & 0,03 & 0,02 & 0,02 & 0,01 & 0,01 \\
\hline $\begin{array}{l}\text { Teste F } \\
\text { C.V. (\%) }\end{array}$ & $\begin{array}{l}3,54 \mathrm{~ns} \\
14,34\end{array}$ & $\begin{array}{l}10,59 * * \\
20,81\end{array}$ & $\begin{array}{l}10,36 * * \\
23,83\end{array}$ & $\begin{array}{l}7,22 * * \\
16,98\end{array}$ & $\begin{array}{l}12,66 * * \\
12,42\end{array}$ \\
\hline
\end{tabular}

$* *$ significativo a $1 \%$ de probabilidade

ns não significativo

Tabela 29. Equações de regressão, coeficientes de determinação $\left(R^{2}\right)$, pon tos de máximo (PM) do teor percentual de fósforo $(\%=x)$ nas di versas partes da planta em função das idades (meses $=\mathrm{x}$ ).

\begin{tabular}{|c|c|c|c|c|}
\hline \multirow{2}{*}{$\begin{array}{l}\text { Partes } \\
\text { da planta }\end{array}$} & \multirow{2}{*}{$\begin{array}{c}\text { Equações } \\
y=\end{array}$} & \multirow{2}{*}{$\mathrm{R}^{2}$} & \multicolumn{2}{|c|}{ Ponto de máximo } \\
\hline & & & $\mathbf{x}$ & $y$ \\
\hline $\begin{array}{l}\text { Folhas } \\
\text { Ramos } \\
\text { Caule-ponta } \\
\text { Caule-meio } \\
\text { Caule-base }\end{array}$ & $\begin{array}{l}\text { não significativo pelo teste } \mathrm{F} \\
-0,02719+0,00390 \mathrm{x}-0,00004 \mathrm{x}^{2} \\
-0,02114+0,00339 \mathrm{x}-0,00003 \mathrm{x}^{2} \\
0,0508-0,0002 \mathrm{x} \\
0,0470-0,0003 \mathrm{x}\end{array}$ & $\begin{array}{l}83,27 * * \\
98,46 * * \\
76,12 * * \\
92,45 * *\end{array}$ & $\begin{array}{r}- \\
60 \\
58 \\
- \\
-\end{array}$ & $\begin{array}{l}- \\
0,09 \\
0,08 \\
- \\
-\end{array}$ \\
\hline
\end{tabular}

$* *$ significativo a $1 \%$ de probabilidade 
A anālise de variância das concentrações de fósforo nas diversas partes da planta em função das idades mos tra diferenças significativas nas partes estudadas, com exceção das folhas que tiveram comportamento semelhante em todas as idades.

Observa-se pela Tabela 29 que para ramos e pon ta do caule as concentrações de fósforo em função das idades são representadas por equações de regressão quadráticas, com máximos de $0,09 \%$ aos 60 meses para ramos e $0,03 \%$ aos 58 meses de idade para ponta do caule.

Quanto ao meio e base do caule, ajustou-se equa ção da regressão 1 inear, nos quais a concentração decresce com a idade da planta.

As concentrações estimadas aos 24 e 96 meses de idade foram para ramos $0,05 \%$ e $0,05 \%$; para ponta do caule $0,04 \%$ e $0,03 \%$; para meio do caule $0,04 \%$ e $0,03 \%$ e para base do caule $0,04 \%$ e $0,03 \%$. Para folhas as concentrações observadas foram $0,10 \%$ e $0,10 \%$. Observa-se que estes valores estão abaixo daqueles encontrados nos örgãos de plantas com nítidos sintomas visuais de carência do elemento, com exceção das folhas (folhas superiores $0,08 \%$; folhas inferiores $0,04 \%$; ramos $0,13 \%$ e cau 1 e $0,07 \%$ ). 
b) Acủmu 10

os resultados obtidos sobre o acúmulo de fósforo nas diversas partes da planta e resumo da análise da va riância, acham-se na Tabela 30 , enquanto que as equações de regressão, coeficientes de determinação e pontos de mínimo na Tabela 31 .

Pela Tabela 30 observa-se que houve diferenf̧as no acúmulo de fósforo em função das idades, tanto para a planta inteira como para as diversas partes amostradas.

As quantidades de fósforo acumuladas tanto nas folhas como no meio e base do caule, ajustaram-se equações de regressão do 20 grau com mínimos de $1,59 \mathrm{~g}$ aos 8 meses de ida de para folhas; $0,03 \mathrm{~g}$ aos 2 meses de idade para meio do caule e $0,08 \mathrm{~g}$ aos 10 meses de idade para base do caule (Tabela $31)$.

Para ramos, ponta do caule e planta inteirahou ve um aumento na quantidade do elemento de forma linear com a maturidade da planta.

Aos 24 e 96 meses de idade verificou-se acúmulos estimados, respectivamente, de 1,06 e $1,06 \mathrm{~g}$ de $\mathrm{P} / \mathrm{kg}$ de folhas; 0,50 e $0,50 \mathrm{~g}$ de $\mathrm{P} / \mathrm{kg}$ de ramos; 0,43 e $0,34 \mathrm{~g}$ de $\mathrm{P} / \mathrm{kg}$ de ponta do caule; 0,45 e $0,30 \mathrm{~g}$ de $\mathrm{P} / \mathrm{kg}$ de meio do caule e 0,41 e $0,30 \mathrm{~g}$ de $\mathrm{P} / \mathrm{kg}$ de base do caule.

Observou-se acúmulos estimados de fósforo ( $g /$ planta) aos 24 e 96 meses de idade em 1,89 e 11,03 g para fo- 
Tabela 30. Quantidades de fósforo ( $\mathrm{g}$ ) acumuladas nas diversas partes da planta em função das idades (Média de 5 repetições).

\begin{tabular}{|c|c|c|c|c|c|c|}
\hline \multirow{2}{*}{$\begin{array}{c}\text { Idade } \\
\text { (meses) }\end{array}$} & \multirow{2}{*}{ Folhas } & \multirow{2}{*}{ Ramos } & \multicolumn{3}{|c|}{ Caule } & \multirow{2}{*}{ Total } \\
\hline & & & Ponta & Meio & Base & \\
\hline $\begin{array}{l}24 \\
36 \\
48 \\
96\end{array}$ & $\begin{array}{c}1,88 \mathrm{c} \\
2,56 \mathrm{bc} \\
3,50 \mathrm{~b} \\
11,04 \mathrm{a}\end{array}$ & $\begin{array}{c}1,07 c \\
4,92 b c \\
4,61 b \\
11,60 a\end{array}$ & $\begin{array}{l}0,18 c \\
0,54 c \\
1,93 b \\
6,43 a\end{array}$ & $\begin{array}{l}0,37 c \\
0,58 b c \\
2,24 b \\
9,29 a\end{array}$ & $\begin{array}{r}0,49 b \\
0,92 b \\
2,53 b \\
11,93 a\end{array}$ & $\begin{array}{c}3,99 \mathrm{c} \\
9,52 \mathrm{bc} \\
14,81 \mathrm{~b} \\
50,27 \mathrm{a}\end{array}$ \\
\hline DMS (5\%) & 1,52 & 3,80 & 0,94 & 1,85 & 2,27 & 6,75 \\
\hline $\begin{array}{l}\text { Teste } \mathrm{F} \\
\text { C.V. (\% }\end{array}$ & $\begin{array}{c}128,33 * * \\
17,68\end{array}$ & $\begin{array}{l}21,93 * * \\
37,82\end{array}$ & $\begin{array}{l}151,41 * * \\
22,99\end{array}$ & $\begin{array}{l}83,46 * * \\
32,86\end{array}$ & $\begin{array}{l}92,45 * * \\
31,54\end{array}$ & $\begin{array}{c}157,07 * * \\
18,96\end{array}$ \\
\hline
\end{tabular}

$* *$ significativo a $1 \%$ de probabilidade

Tabela 31. Equações de regressão, coeficientes de determinação $\left(R^{2}\right)$, pontos de mínimo (Pm) da quantidade de fósforo $(g=y)$ acumuladas nas diversas partes da planta em função das idades (meses $=x$ ).

\begin{tabular}{|c|c|c|}
\hline Partes da & Equações & Ponto de mínimo \\
\hline
\end{tabular}

\begin{tabular}{llllc}
\hline Folhas & $1,6883-0,0209 x+0,0012 x^{2}$ & $99,99 * *$ & 8 & 1,59 \\
Ramos & $-1,3731+0,1358 x$ & $94,92 * *$ & - & - \\
Caule-ponta & $-2,3452+0,0905 x$ & $98,86 * *$ & - & - \\
Caule-meio & $-0,3258-0,0030 x+0,0011 x^{2}$ & $99,57 * *$ & 2 & 0,03 \\
Caule-base & $0,2444-0,0326 x+0,0016 x^{2}$ & $99,89 * *$ & 10 & 0,08 \\
\hline Total & $13,9307+0,6585 x$ & $98,94 * *$ & - & - \\
\hline
\end{tabular}

$* *$ significativo a $1 \%$ de probabilidade 
1 has; 1,88 e $11,66 \mathrm{~g}$ para ramos; 0,17 e $6,34 \mathrm{~g}$ para ponta do caule; 0,22 e 9,28 g para meio do caule; 0,39 e 11,94 g para base do caule e 4,55 e 50,25 g para planta inteira.

\subsubsection{Potás sio}

\section{a) Concentração}

Os resultados analíticos referentes à concentração de potássio nas diferentes partes da planta, em função das idades, são apresentados nas Tabelas 32 e 33.

Analisando-se a Tabela 32 , verifica-se que hou ve diferenças nas concentrações de potässio em função das ida des para todas as partes amostradas da planta. Por outro lado, observa-se que as maiores concentrações ocorreram aos 24 meses de idade em todos os órgãos da planta.

De acordo com a Tabela 33 , constata-se que os valores de concentração de potássio nas folhas, ajustou-se a uma regressão quadrätica, com alto valor de coeficiente de de terminação e um máximo de $1,87 \%$ aos 35 meses de idade.

Para os ramos, ponta e meio do caule ajusta-

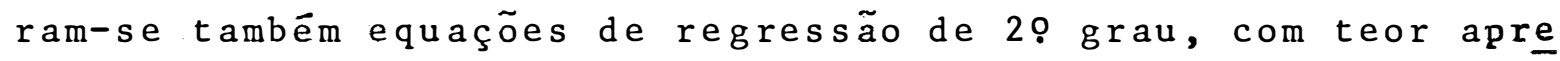
sentando mínimos de $0,29 \%$ aos 72 meses para ramos; $0,29 \%$ aos 93 meses para ponta do caule e $0,23 \%$ de potässio aos 85 meses de idade para meio do caule.

o teor de potássio nabase do caule diminuiu com a idade da planta, ajustando-se a uma equação linear. 
Tabela 32. Teor percentual de potāssio(\%) contido na matëria seca das diversas partes da planta em função das idades (Média de 5 repetiçōes).

\begin{tabular}{cccccc}
\hline & & & \multicolumn{3}{c}{ Caule } \\
Idade & Folhas & Ramos & Ponta & Meio & Base \\
\cline { 5 - 6 } & & & & & \\
\hline 24 & $1,78 \mathrm{ab}$ & $0,62 \mathrm{a}$ & $0,59 \mathrm{a}$ & $0,58 \mathrm{a}$ & $0,37 \mathrm{a}$ \\
36 & $1,96 \mathrm{a}$ & $0,37 \mathrm{~b}$ & $0,44 \mathrm{~b}$ & $0,39 \mathrm{~b}$ & $0,34 \mathrm{ab}$ \\
48 & $1,74 \mathrm{~b}$ & $0,42 \mathrm{~b}$ & $0,44 \mathrm{~b}$ & $0,38 \mathrm{~b}$ & $0,27 \mathrm{~b}$ \\
96 & $0,42 \mathrm{c}$ & $0,36 \mathrm{~b}$ & $0,29 \mathrm{c}$ & $0,24 \mathrm{c}$ & $0,18 \mathrm{c}$ \\
\hline DMS (5\%) & 0,18 & 0,09 & 0,08 & 0,12 & 0,08 \\
\hline Teste F & $250,08 * *$ & $28,43 * *$ & $39,66 * *$ & $21,01 * *$ & $15,61 * *$ \\
C.V. (\%) & 6,83 & 11,59 & 10,08 & 16,79 & 16,26 \\
\hline
\end{tabular}

** significativo a $1 \%$ de probabilidade

Tabela 33. Equações de regressão, coeficientes de determinação $\left(\mathrm{R}^{2}\right)$, pontos de máximo (PM), pontos de mínimo ( $\mathrm{Pm}$ ) do teor percentual de potássio $(\%=y)$ nas diversas partes da planta em função das idades (meses $=\mathrm{x}$ ).

\begin{tabular}{|c|c|c|c|c|c|c|}
\hline \multirow{2}{*}{$\begin{array}{l}\text { Partes } \\
\text { da planta }\end{array}$} & \multirow{2}{*}{$\begin{array}{c}\text { Equações } \\
\mathrm{y}=\end{array}$} & \multirow{2}{*}{$\mathrm{R}^{2}$} & \multicolumn{2}{|c|}{$\begin{array}{l}\text { Ponto de } \\
\text { máximo }\end{array}$} & \multicolumn{2}{|c|}{$\begin{array}{l}\text { Ponto de } \\
\text { mínimo }\end{array}$} \\
\hline & & & $x$ & y & $\mathbf{x}$ & y \\
\hline $\begin{array}{l}\text { Folhas } \\
\text { Ramos }\end{array}$ & $\begin{array}{l}1,3939+0,0271 x-0,0004 x_{2}^{2} \\
0,9582-0,0184 x+0,0001 x^{2}\end{array}$ & $\begin{array}{l}99,13 * * \\
74,06 * *\end{array}$ & 35 & 1,87 & $7 \overline{2}$ & 0,29 \\
\hline $\begin{array}{l}\text { Caule-ponta } \\
\text { Caule-meio }\end{array}$ & $\begin{array}{l}0,81075-0,01125 x+0,00004 x^{2} \\
0,86756-0,01496 x+0,00009 x 2\end{array}$ & $\begin{array}{l}93,45 * * \\
93,27 * *\end{array}$ & - & - & $\begin{array}{l}93 \\
85\end{array}$ & $\begin{array}{l}0,29 \\
0,23\end{array}$ \\
\hline Caule-base & $0,4257-0,0026 x$ & $96,21 * *$ & - & - & - & - \\
\hline
\end{tabular}

** significativo a $1 \%$ de probabilidade 
As concentrações estimadas de potássio aos 24 e 96 meses de idade foram de $1,82 \%$ e $0,41 \%$ para folhas; $0,59 \%$ e $0,36 \%$ para ramos; $0,57 \%$ e $0,29 \%$ para ponta do caule; $0,56 \%$ e $0,25 \%$ para meio do caule e $0,36 \%$ e $0,17 \%$ para base do caule. Comparando com os valores obtidos em plantas deficientes (fo1has superiores $0,33 \%$; folhas inferiores $0,07 \%$; ramos $0,36 \%$ e caule $0,40 \%)$, observa-se que aos 24 meses de idade os teores encontrados estão acima dos 1 imites de carência, enquanto para plantas com 96 meśs de idade apenas as concentrações encontradas no caule estão abaixo.

b) Acūmu 10

As quantidades de potás sio acumuladas nas diferentes partes e na planta inteira, em função das idades e o resumo da anālise de variância, são apresentados na Tabela 34 e as equações de regressão, coeficientes de determinação e pontos de máximo e mínimo na Tabela 35.

Pela Tabela 34 observa-se que houve diferenças no acūmulo do potássio em função das idades para as partes e planta inteira.

Os valores de acúmulo de potássio nas folhas, ponta, meio e base do caule ajustaram-se a equações de regres são quadráticas (Tabela 35), constatando-se um máximo de acümulo igual a $58,17 \mathrm{~g}$ aos 66 meses de idade para folhas e minimos de $0,74 \mathrm{~g}$ aos 12 meses para ponta do caule; $1,97 \mathrm{~g}$ aos 11 meses para meio do caule e $0,69 \mathrm{~g}$ aos 7 meses para base do caule. 
Tabela 34. Quantidades de potássio ( $\mathrm{g}$ ) acumuladas nas diversas partes da plantá em função das idades (Média de 5 repetiçōes).

\begin{tabular}{|c|c|c|c|c|c|c|}
\hline \multirow{2}{*}{$\begin{array}{c}\text { Idade } \\
\text { (meses) }\end{array}$} & \multirow{2}{*}{ Folhas } & \multirow{2}{*}{ Ramos } & \multicolumn{3}{|c|}{ Caule } & \multirow{2}{*}{ Total } \\
\hline & & & Ponta & Meio & Base & \\
\hline $\begin{array}{l}24 \\
36 \\
48 \\
96\end{array}$ & $\begin{array}{l}31,48 \mathrm{~b} \\
37,39 \mathrm{~b} \\
56,44 \mathrm{a} \\
43,31 \mathrm{ab}\end{array}$ & $\begin{array}{l}12,77 b \\
21,25 b \\
28,16 b \\
83,58 a\end{array}$ & $\begin{array}{r}2,61 b \\
3,58 b \\
11,90 b \\
54,98 a\end{array}$ & $\begin{array}{r}5,01 b \\
5,83 b \\
18,87 b \\
81,90 \mathrm{a}\end{array}$ & $\begin{array}{c}4,60 c \\
7,34 b c \\
19,61 b \\
83,51 a\end{array}$ & $\begin{array}{r}56,48 \mathrm{c} \\
82,30 \mathrm{c} \\
128,08 \mathrm{~b} \\
347,28 \mathrm{a}\end{array}$ \\
\hline DMS (5\%) & 10,98 & 22,48 & 9,99 & 28,18 & 13,49 & 40,82 \\
\hline $\begin{array}{l}\text { Teste } F \\
\text { C.V. (\%) }\end{array}$ & $\begin{array}{l}15,50 \% * \\
14,38\end{array}$ & $\begin{array}{l}33,34 * * \\
34,05\end{array}$ & $\begin{array}{c}101,33 * * \\
30,18\end{array}$ & $\begin{array}{l}27,58 * * \\
55,78\end{array}$ & $\begin{array}{c}123,88 * * \\
25,89\end{array}$ & $\begin{array}{c}172,85 * * \\
14,67\end{array}$ \\
\hline
\end{tabular}

$* *$ significativo a $1 \%$ de probabilidade

Tabela 35. Equações de regressão, coeficientes de determinação $\left(R^{2}\right)$, ponto de máximo (PM) e pontos de mímimo (Pm) das quantidades de potássio ( $\mathrm{g}=\mathrm{y})$ acumuladas nas diversas partes da planta em fun ção das idades (meses $=x$ ).

\begin{tabular}{|c|c|c|c|c|c|c|}
\hline \multirow{2}{*}{$\begin{array}{l}\text { Partes } \\
\text { da planta }\end{array}$} & \multirow{2}{*}{$\begin{array}{c}\text { Equações } \\
y=\end{array}$} & \multirow[t]{2}{*}{$\mathrm{R}^{2}$} & \multicolumn{2}{|c|}{$\begin{array}{l}\text { Ponto de } \\
\text { máximo }\end{array}$} & \multicolumn{2}{|c|}{$\begin{array}{l}\text { Ponto de } \\
\text { mínimo }\end{array}$} \\
\hline & & & $\mathrm{x}$ & $\mathrm{y}$ & $x$ & $y$ \\
\hline $\begin{array}{l}\text { Folhas } \\
\text { Ramos } \\
\text { Caule-ponta } \\
\text { Caule-meio } \\
\text { Caule-base }\end{array}$ & $\begin{array}{r}-13,5857+2,1695 x-1,6399 x^{2} \\
-13,5709+0,9806 x \\
1,7618-0,1768 x+0,0076 x^{2} \\
3,3816-0,2511 x+0,0111 x_{2}^{2} \\
1,2019-0,1469 x+0,0105 x^{2}\end{array}$ & $\begin{array}{l}84,19 * * \\
93,24 * * \\
99,75 * * \\
99,65 * * \\
99,81 * *\end{array}$ & $\begin{array}{l}66 \\
- \\
- \\
-\end{array}$ & $\begin{array}{c}58,17 \\
- \\
- \\
-\end{array}$ & $\begin{array}{r}- \\
- \\
12 \\
11 \\
7\end{array}$ & $\begin{array}{l}- \\
- \\
0,74 \\
1,97 \\
0,69\end{array}$ \\
\hline Total & $-59,5449+4,1781 x$ & $99,01 * *$ & - & - & - & - \\
\hline
\end{tabular}

** significativo a $1 \%$ de probabilidade 
Os ramos e planta inteira acumularam potássio com a maturidade da planta ajustando-se equações de regressão 1 ineares.

Encontrou-se acūmulos de potässio aos 24 e 96 meses de idade èstimados em 18,22 e $4,12 \mathrm{~g}$ de K/kg de folhas; 5,90 e $3,63 \mathrm{~g}$ de K/kg de ramos; 5,75 e $2,90 \mathrm{~g}$ de K/kg de ponta do caule; 5,60 e $2,50 \mathrm{~g}$ de $\mathrm{K} / \mathrm{kg}$ de meio do caule e 3,63 e $1,74 \mathrm{~g}$ de $\mathrm{K} / \mathrm{kg}$ de base do caule.

Aos 24 e 96 meses de idade os acúmulos estimados de potássio (g/planta) foram para folhas 29,03 e 43,56 g; para ramos 9,96 e $80,57 \mathrm{~g}$; para ponto do caule 1,91 e 55,05 g; para meio do caule, 3,77 e $82,02 \mathrm{~g}$; para base do caule 3,70 e $83,60 \mathrm{~g}$ e para planta inteira 48,37 e $344,80 \mathrm{~g}$.

4.2.2.4. Cá1cio

a) Concentração

Nas Tabelas 36 e 37 acham-se expostos os rresultados analíticos sobre a concentração de cálcio nas diversas partes da planta em função das idades.

Pela Tabela 36 constata-se que os teores de cálcio mostraram uma tendência a aumentar com a idade, enquan to que a concentração do nitrogênio, fósforo e potảssio diminuiu com a idade da planta. 
Tabela 36. Teor percentual de cálcio (\%) contido na matéria seca das diversas partes da planta, em função dasidades (Média de 5 repetições).

\begin{tabular}{llllll}
\hline \multirow{2}{*}{$\begin{array}{c}\text { Idade } \\
\text { meses) }\end{array}$} & Folhas & Ramos & \multicolumn{3}{c}{ Caile } \\
\cline { 4 - 6 } & & & Ponta & Meio & Base \\
\hline 24 & $0,66 \mathrm{~b}$ & $0,57 \mathrm{a}$ & $0,27 \mathrm{~b}$ & $0,29 \mathrm{~b}$ & $0,41 \mathrm{~b}$ \\
36 & $0,75 \mathrm{~b}$ & $0,36 \mathrm{~b}$ & $0,19 \mathrm{bc}$ & $0,19 \mathrm{~b}$ & $0,47 \mathrm{~b}$ \\
48 & $0,80 \mathrm{ab}$ & $0,39 \mathrm{~b}$ & $0,25 \mathrm{~b}$ & $0,24 \mathrm{~b}$ & $0,43 \mathrm{~b}$ \\
96 & $1,02 \mathrm{a}$ & $0,67 \mathrm{a}$ & $0,35 \mathrm{a}$ & $0,42 \mathrm{a}$ & $0,63 \mathrm{a}$ \\
\hline DMS (5\%) & 0,25 & 0,13 & 0,08 & 0,11 & 0,11 \\
\hline Teste F & $6,04 * *$ & $19,93 * *$ & $11,83 * *$ & $13,10 * *$ & $12,72 * *$ \\
C.V. (\%) & 17,26 & 14,90 & 15,73 & 21,72 & 13,07 \\
\hline
\end{tabular}

** significativo a $1 \%$ de probabilidade

Tabela 37. Equações de regressão, coeficientes de determinação $\left(R^{2}\right)$, pontos de mínimo $(\mathrm{Pm})$ do teor percentual de cálcio $(\%=y)$ nas di versas partes da planta em função das idades (meses $=\mathrm{x}$ ).

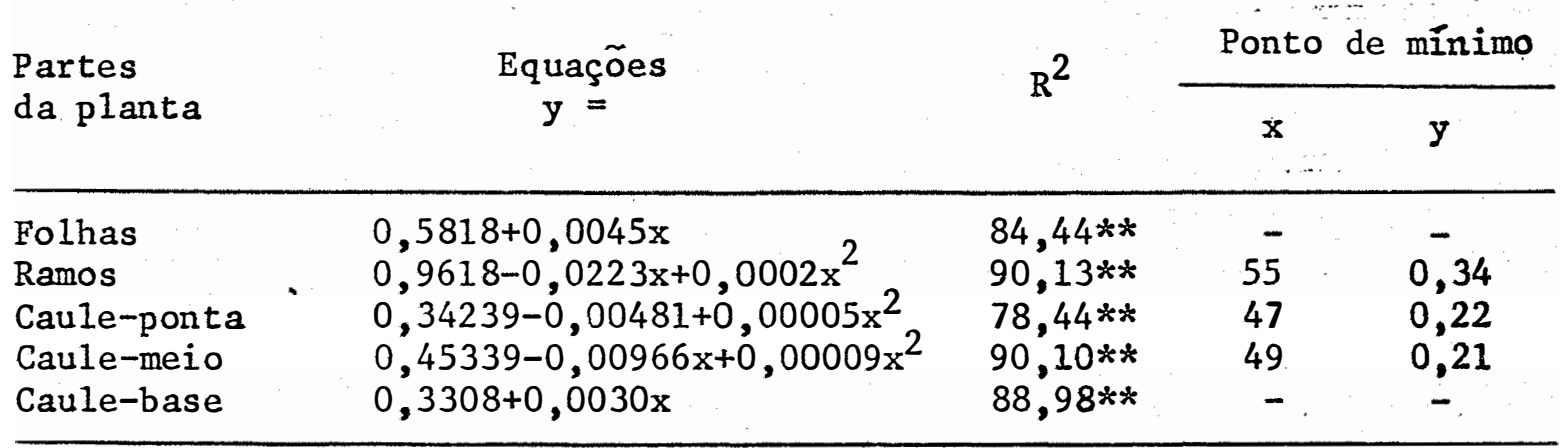

** significativo a $1 \%$ de probabilidade 
Verifica-se pela Tabela 37 , que o teor de cālcio nas folhas e na base do caule aumentaram linearmente com a idade da planta.

Nos ramos, ponta e meio do caule as concentrações de cálcio foram representadas por equações de regressão quadräticas, mostrando mínimos de $0,34 \%$ aos 55 meses para ramos; $0,22 \%$ aos 47 meses para ponta do caule e $0,21 \%$ aos 49 me ses de idade para meio do caule.

Aos 24 e 96 meses de idade as concentrações es timadas de cálcio foram de $0,69 \%$ e $1,01 \%$ para folhas; $0,54 \%$ e $0,67 \%$ para ramos; $0,26 \%$ e $0,35 \%$ para ponta do caule; $0,28 \%$ e $0,42 \%$ para meio do caule e $0,40 \%$ e $0,62 \%$ para base do caule. Confrontando com as concentrações observadas para plantas carentes em cálcio (folhas superiores 0,95\%; folhas inferiores $1,66 \%$; ramos $0,42 \%$ e caule $0,32 \%$ ) constata-se que o teor do elemento observado nas folhas de plantas com 24 meses foi inferior, ao teor verificado em plantas carentes, enquanto que nos ramos foi superior. Nas plantas com 96 meses de idade os teores encontrados nos ramos e caule foram maiores do que os das plantas deficientes.

b) Acūmu 10

As quantidades de cālcio acumuladas em função das idades das plantas e o resumo na anālise de variância encontram-se na Tabela 38 , enquanto que as equações de regres- 
são, coeficientes de determinação e pontas de mínimo acham-se na Tabela 39.

Pela Tabela 38 verifica-se que embora não tenha havido diferenças significativas no acúmulo de cälcio nas primeiras idades para as diversas partes e planta inteira, e tas diferenças foram se tornando evidentes com a maturidade da planta, pois como era de se esperar, os maiores valores estão diretamente relacionados com a quantidade de biomassa produzida.

As quantidades de cälcio acumuladas nas diferentes partes e para planta inteira ajustaram-se a equações de regressão quadráticas (Tabela 39), com mínimos de $11,84 \mathrm{~g}$ aos 20 meses de idade para folhas; 15,46 g aos 29 meses para ramos; $0,90 \mathrm{~g}$ aos 28 meses para ponta do caule; $1,44 \mathrm{~g}$ aos 30 meses para meio do caule; $4,76 \mathrm{~g}$ aos 27 meses para base do cau le e 35,50 aos 27 meses de idade para planta inteira.

Aos 24 e 96 meses de idade encontrou-se acümulos estimados de 6,90 e $10,11 \mathrm{~g}$ de Ca/kg de folhas; 5,43 e $6,74 \mathrm{~g}$ de Ca/kg de ramos; 2,60 e 3,53 g de Ca/kg de ponta do caule; 2,80 e 4,25 g de Ca/kg de meio do caule e 4,03 e 6,2lg de Ca/kg de base do caule.

os acúmulos estimados para quantidades de cálcio em g/planta aos 24 e 96 meses de idade foram de 12,06 e $105,87 \mathrm{~g}$ para folhas; 16,24 e $157,07 \mathrm{~g}$ para ramos; 1,08 e 67,34 $\mathrm{g}$ para ponta do caule; 2,57 e 140,92 g para meio do caule; 5,41 e 290,31 g para base do caule e 37,36 e $761,54 \mathrm{~g}$ para planta inteira. 
Tabela 38. Quantidade de câlcio ( $\mathrm{g}$ ) acumulada nas diversas partes da planta em função das idades (Média de 5 repetições).

\begin{tabular}{|c|c|c|c|c|c|c|}
\hline \multirow{2}{*}{$\begin{array}{c}\text { Idade } \\
\text { (meses) }\end{array}$} & \multirow{2}{*}{ Folhas } & \multirow{2}{*}{ Ramos } & \multicolumn{3}{|c|}{ Caule } & \multirow{2}{*}{ Total } \\
\hline & & & Ponta & Meio & Base & \\
\hline $\begin{array}{l}24 \\
36 \\
48 \\
96\end{array}$ & $\begin{array}{r}13,33 \mathrm{~b} \\
12,79 \mathrm{~b} \\
26,28 \mathrm{~b} \\
105,75 \mathrm{a}\end{array}$ & $\begin{array}{r}11,87 \mathrm{~b} \\
27,51 \mathrm{~b} \\
20,33 \mathrm{~b} \\
157,87 \mathrm{a}\end{array}$ & $\begin{array}{r}1,21 \mathrm{~b} \\
1,58 \mathrm{~b} \\
7,00 \mathrm{~b} \\
67,33 \mathrm{a}\end{array}$ & $\begin{array}{r}2,50 \mathrm{~b} \\
2,78 \mathrm{~b} \\
11,73 \mathrm{~b} \\
140,93 \mathrm{a}\end{array}$ & $\begin{array}{c}5,02 c \\
10,28 b c \\
30,11 b \\
290,36 a\end{array}$ & $\begin{array}{r}33,93 b \\
54,94 b \\
95,45 b \\
762,24 a\end{array}$ \\
\hline DMS (5\%) & 28,33 & 56,29 & $12 ; 77$ & 48,91 & 22,05 & 126,03 \\
\hline $\begin{array}{l}\text { Teste F } \\
\text { C.V. (\%) }\end{array}$ & $\begin{array}{l}70,29 * * \\
28,32\end{array}$ & $\begin{array}{l}24,71 * * \\
57,23\end{array}$ & $\begin{array}{c}103,87 * * \\
36,56\end{array}$ & $\begin{array}{l}51,70 * * \\
53,36\end{array}$ & $\begin{array}{c}642,55 * * \\
14,50\end{array}$ & $\begin{array}{c}209,09 * * \\
22,95\end{array}$ \\
\hline
\end{tabular}

** significativo a $1 \%$ de probabilidade

Tabela 39 - Equações de regressão, coeficientes de determinação $\left(R^{2}\right)$, pon tos de mínimo $(\mathrm{Pm})$ das quantidades de cálcio $(\mathrm{g}=\mathrm{y})$ acumula $=$ das nas diversas partes da planta em função das idades (meses $=\mathrm{x}$ ).

\begin{tabular}{lllll}
$\begin{array}{l}\text { Partes } \\
\text { da planta }\end{array}$ & $\begin{array}{c}\text { Equações } \\
\mathrm{y}=\end{array}$ & $\mathrm{R}^{2}$ & \multicolumn{2}{c}{ Ponto de mínimo } \\
\cline { 5 - 6 } & & & $\mathrm{x}$ & $\mathrm{y}$ \\
\hline Folhas & $18,7069-0,6720 \mathrm{x}+0,0165 \mathrm{x}^{2}$ & $99,74 * *$ & 20 & 11,84 \\
Ramos & $41,9020-1,8255 \mathrm{x}+0,0315 \mathrm{x}^{2}$ & $98,78 * *$ & 29 & 15,46 \\
Caule-ponta & $11,7161-0,7840 \mathrm{x}+0,0142 \mathrm{x}^{2}$ & $99,98 * *$ & 28 & 0,90 \\
Caule-meio & $30,1570-1,9168 \mathrm{x}+0,0319 \mathrm{x}^{2}$ & $99,99 * *$ & 30 & 1,44 \\
Caule-base & $49,8119-3,3016 \mathrm{x}+0,0605 \mathrm{x}^{2}$ & $99,99 * *$ & 27 & 4,76 \\
\hline Total & $152,2940-8,4999 x+0,1546 \mathrm{x}^{2}$ & $99,96 * *$ & 27 & 35,50 \\
\hline
\end{tabular}


4.2.2.5. Magnēsio.

a) Concentração

Os resultados analíticos referentes à concentração de magnésio nas diversas partes da planta em função das idades, acham-se nas Tabelas 40 e 41 .

Embora não tenha ocorrido diferenças na concentração de magnésio nas idades de 24,36 e 48 meses para ra mos e caule (base, meio e ponta) observa-se pelos dados (Tabe las 40) que existe uma tendência de aumento da concentraçãodo nutriente, uma vez que aos 96 meses de idade a concentração foi superior às outras idades. Para folhas, as diferenças na concentração do elemento jä se evidenciaram a partir dos 36 meses de idade.

Através da Tabela 41 constata-se que equações de regressão de 19 grau, ajustaram-se ao acréscimo linear da concentração de magnésio nas folhas e ramos, aumentando o teor do elemento com a idade da planta.

Para ponta, meio e base do caule ajustaram-se equações de regressão quadräticas com mínimos de concentração de $0,03 \%$ aos 32 meses para ponta do caule; $0,04 \%$ aos 33 meses para meio do caule e $0,05 \%$ aos 23 meses de idade para base do caule.

Concentrações estimadas de magnésio aos 2.4 e 96 meses de idade da planta foram de $0,17 \%$ e $0,65 \%$ para fo1 has; $0,04 \%$ e $0,12 \%$ para ramos; $0,04 \%$ e $0,23 \%$ para ponta: 
Tabela 40. Teor percentual de magnësio (\%) contido na matēria seca das di versas partes da planta em função das idades (Média de 5 repetiçōes).

\begin{tabular}{llllll}
\hline \multirow{2}{*}{$\begin{array}{c}\text { Idade } \\
\text { (meses) }\end{array}$} & Folhas & Ramos & \multicolumn{3}{c}{ Caule } \\
\cline { 4 - 6 } & & & Ponta & Meio & Base \\
\hline 24 & $0,17 \mathrm{c}$ & $0,04 \mathrm{~b}$ & $0,03 \mathrm{~b}$ & $0,03 \mathrm{~b}$ & $0,05 \mathrm{~b}$ \\
36 & $0,21 \mathrm{c}$ & $0,05 \mathrm{~b}$ & $0,04 \mathrm{~b}$ & $0,04 \mathrm{~b}$ & $0,05 \mathrm{~b}$ \\
48 & $0,34 \mathrm{~b}$ & $0,06 \mathrm{~b}$ & $0,05 \mathrm{~b}$ & $0,05 \mathrm{~b}$ & $0,08 \mathrm{~b}$ \\
96 & $0,65 \mathrm{a}$ & $0,12 \mathrm{a}$ & $0,23 \mathrm{a}$ & $0,21 \mathrm{a}$ & $0,26 \mathrm{a}$ \\
\hline DMS (5\%) & 0,11 & 0,02 & 0,05 & 0,03 & 0,05 \\
\hline Teste F & $55,97 * *$ & $30,04 * *$ & $52,86 * *$ & $104,51 * *$ & $110,09 * *$ \\
C.V. (\%) & 18,36 & 19,80 & 33,02 & 21,72 & 18,41 \\
\hline
\end{tabular}

** significativo a $1 \%$ de probabilidade

Tabela 41. Equações de regressão, coeficientes de determinação $\left(R^{2}\right)$, pontos de mínimo $(\mathrm{Pm})$ do teor percentual de magnésio $(\%=y)$ nas diversas partes da planta em função das idades (meses $=\mathrm{x}$ ).

\begin{tabular}{lllll}
\hline $\begin{array}{l}\text { Partes } \\
\text { da planta }\end{array}$ & \multicolumn{1}{c}{$\begin{array}{c}\text { Equações } \\
\mathrm{y}=\end{array}$} & $\mathrm{R}^{2}$ & \multicolumn{2}{c}{ Ponto de mínimo } \\
\cline { 3 - 5 } & & & $\mathrm{x}$ & $\mathrm{y}$ \\
\hline Folhas & $0,0047+0,0067 \mathrm{x}$ & $98,67 * *$ & - & - \\
Ramos & $0,0169+0,0010 \mathrm{x}$ & $93,76 * *$ & - & - \\
Caule-ponta & $0,08329-0,00300 x+0,00005 \mathrm{x}^{2}$ & $99,89 * *$ & 32 & 0,03 \\
Caule-meio & $0,08671-0,00291 x+0,00004 x^{2}$ & $99,41 * *$ & 33 & 0,04 \\
Caule-base & $0,07561-0,00178 x+0,00004 x^{2}$ & $99,80 * *$ & 23 & 0,05 \\
\hline
\end{tabular}

** significativo a $1 \%$ de probabilidade 
$0,04 \%$ e $0,21 \%$ para.meio e $0,05 \%$ e $0,26 \%$ para base do caule. Comparando com os teores verificados para plantas deficientes em magnésio (folhas superiores $0,34 \%$; folhas inferiores $0,26 \%$; ramos $0,12 \%$ e caule $0,09 \%$ ) observa-se que as concentrações es timadas para folhas e caule (ponta, meio e base) em plantas com 96 meses foram superiores aos órgãos correspondentes às plantas carentes, enquanto nos ramos as concentrações foram iguais. Nas plantas com 24 meses de idade os valores estimados para todas as partes foram inferiores aos das plantas deficientes.

b) Acūmu 10

As quantidades de magnësio acumuladas nas diversas partes e na planta inteira em função das idades e o re sumo de anālise de variância encontram-se na Tabela 42 e as equações de regressão, coeficientes de determinação e pontos de mínimo na Tabela 43.

0 acúmulo de magnēsio nas diversas partes e na planta inteira foi crescente (Tabela 42), embora as primeiras idades não tenham mostrado diferenças entre sị, acentuando-se, porëm, aos 96 meses de idade, aliada a uma maior produção de matēria seca.

Para todas as partes, assim como na planta inteira, as quantidades acumuladas de magnésio aumentáram de acordo com equações de regressão quadräticas com mínimos de $2,86 \mathrm{~g}$ aos 23 meses de idade para folhas; $1,56 \mathrm{~g}$ aos 26 meses 
Tabela 42. Quantidades de magnësio ( $\mathrm{g}$ ) acumuladas nas diversas partes da planta em função das idades (Média de 5 repetições).

\begin{tabular}{|c|c|c|c|c|c|c|}
\hline \multirow{2}{*}{$\begin{array}{c}\text { Idade } \\
\text { (meses) }\end{array}$} & \multirow{2}{*}{ Folhas } & \multirow{2}{*}{ Ramos } & \multicolumn{3}{|c|}{ Caule } & \multirow{2}{*}{ Total } \\
\hline & & & Ponta & Meio & Base & \\
\hline $\begin{array}{l}24 \\
36 \\
48 \\
96\end{array}$ & $\begin{array}{r}3,28 \mathrm{~b} \\
3,99 \mathrm{~b} \\
11,14 \mathrm{~b} \\
67,43 \mathrm{a}\end{array}$ & $\begin{array}{r}1,03 b \\
3,29 b \\
3,39 b \\
27,99 a\end{array}$ & $\begin{array}{r}0,18 b \\
0,26 b \\
1,37 b \\
43,60 a\end{array}$ & $\begin{array}{r}0,40 \mathrm{~b} \\
0,44 \mathrm{~b} \\
2,61 \mathrm{~b} \\
70,40 \mathrm{a}\end{array}$ & $\begin{array}{r}0,71 b \\
1,22 \mathrm{~b} \\
5,93 \mathrm{~b} \\
121,12 \mathrm{a}\end{array}$ & $\begin{array}{r}5,60 \mathrm{~b} \\
9,20 \mathrm{~b} \\
24,44 \mathrm{~b} \\
330,54 \mathrm{a}\end{array}$ \\
\hline DMS (5\%) & 8,36 & 8,68 & 12,22 & 15,26 & 9,72 & 26,10 \\
\hline $\begin{array}{l}\text { Teste F } \\
\text { C.V }(\%)\end{array}$ & $\begin{array}{c}223,22 * x \\
21,50\end{array}$ & $\begin{array}{l}35,34 * * \\
53,72\end{array}$ & $\begin{array}{l}50,72 * * \\
59,45\end{array}$ & $\begin{array}{l}84,51 * * \\
45,63\end{array}$ & $\begin{array}{c}609,34 * * \\
16,65\end{array}$ & $\begin{array}{c}708,10 * * \\
15,58\end{array}$ \\
\hline
\end{tabular}

*: significativo a $1 \%$ de probabilidade

Tabela 43. Equações de regressão, coeficientes de determinação $\left(R^{2}\right)$, pontos de mínimo $(\mathrm{Pm})$ das quantidades de magnésio $(\mathrm{g}=\mathrm{y})$ acumuladas nas diversas partes da planta em função das idades (meses $=x$ ).

\begin{tabular}{|c|c|c|c|c|}
\hline \multirow{2}{*}{$\begin{array}{l}\text { Partes } \\
\text { da planta }\end{array}$} & \multirow{2}{*}{$\begin{array}{c}\text { Equações } \\
y=\end{array}$} & \multirow{2}{*}{$\mathrm{R}^{2}$} & \multicolumn{2}{|c|}{ Ponto de mínimo } \\
\hline & & & $\mathrm{x}$ & $y$ \\
\hline $\begin{array}{l}\text { Folhas } \\
\text { Ramos } \\
\text { Caule-ponta } \\
\text { Caule-meio } \\
\text { Caule-base }\end{array}$ & $\begin{array}{r}9,0901-0,5478 x+0,0120 x_{2}^{2} \\
5,2876-0,2844 x+0,0054 x_{2}^{2} \\
12,1547-0,7573 x+0,0113 x_{2}^{2} \\
19,1553-1,1965 x+0,0180 x^{2} \\
30,1872-0,1920 x+0,0298 x^{2}\end{array}$ & $\begin{array}{l}99,93 * * \\
99,43 * * \\
99,93 * * \\
99,95 * * \\
99,96 * *\end{array}$ & $\begin{array}{l}23 \\
26 \\
33 \\
33 \\
32\end{array}$ & $\begin{array}{l}2,86 \\
1,56 \\
0,50 \\
0,60 \\
0,70\end{array}$ \\
\hline otal & $76,0537-4,7118 x+0,0767 x^{2}$ & $99,96 * *$ & 31 & 3,66 \\
\hline
\end{tabular}

$* *$ significativo a $1 \%$ de probabilidade 
para ramos; $0,50 \mathrm{~g}$ aos 33 meses para ponta do caule; $0,60 \mathrm{~g}$ aos 33 meses para meio do caule; $0,70 \mathrm{~g}$ aos 32 meses para ba se do caule e $3,66 \mathrm{~g}$ aos 31 meses de idade para planta inteira (Tabela 43 ).

Aos 24 e 96 meses de idade observou-se acúmulos estimados de 1,70 e $6,51 \mathrm{~g}$ de $\mathrm{Mg} / \mathrm{kg}$ de folhas;0,42 e $1,20 \mathrm{~g}$ de $\mathrm{Mg} / \mathrm{kg}$ de ramos; $0,40 \mathrm{e} 2,30 \mathrm{~g}$ de $\mathrm{Mg} / \mathrm{kg}$ de ponta do caule; 0,42 e 2,12 g de $\mathrm{Mg} / \mathrm{kg}$ de meio do caulee 0,55 e $2,64 \mathrm{~g}$ de $\mathrm{Mg} / \mathrm{kg}$ de base do caule.

Constatou-se aos 24 e 96 meses de idade acúmulos estimados de magnésio (g/planta) ém 2,87 e $67,47 \mathrm{~g}$ para folhas; 1,58 e 27,93 g para ramos; 0,48 e 43,57 g para ponta do caule; 0,82 e 70,36 g para meio do caule; 1,31 e 121,06 g Pa ra base do caule e 7,06 e 330,38 g para planta inteira.

\subsubsection{Enxofre}

a) Concentração

Nas Tabelas 44 e 45 encontram-se os dados analíticos referentes às concentrações de enxofre nas diversas partes da planta, em função das idades.

Observa-se que as concentrações de enxofre nas diferentes partes da planta foram afetadas pela idade, verifi cando-se pela Tabela 44, um decréscimo nos teores do elemento com o envelhecimento da planta, com exceção da base do caule onde os teores foram semelhantes. 
Tabela 44. Teor percentual de enxofre (\%) contido na matéria seca das diversas partes da planta em função das idades (Média de 5 repe tiçöes).

\begin{tabular}{cccccc}
\hline \multirow{2}{*}{$\begin{array}{c}\text { Idade } \\
\text { (meses) }\end{array}$} & Folhas & Ramos & \multicolumn{3}{c}{ Caule } \\
\cline { 4 - 6 } & & & Ponta & Meio & Base \\
\hline 24 & $0,38 \mathrm{a}$ & $0,07 \mathrm{a}$ & $0,05 \mathrm{a}$ & $0,06 \mathrm{a}$ & $0,05 \mathrm{a}$ \\
36 & $0,30 \mathrm{ab}$ & $0,04 \mathrm{~b}$ & $0,02 \mathrm{~b}$ & $0,03 \mathrm{~b}$ & $0,05 \mathrm{a}$ \\
48 & $0,29 \mathrm{ab}$ & $0,04 \mathrm{~b}$ & $0,01 \mathrm{~b}$ & $0,02 \mathrm{bc}$ & $0,04 \mathrm{a}$ \\
96 & $0,27 \mathrm{~b}$ & $0,05 \mathrm{ab}$ & $0,01 \mathrm{~b}$ & $0,01 \mathrm{c}$ & $0,04 \mathrm{a}$ \\
\hline DMS (5\%) & 0,09 & 0,02 & 0,01 & 0,01 & 0,02 \\
\hline Teste F & $3,93 *$ & $6,82 * *$ & $102,67 * *$ & $35,11 * *$ & $1,85 \mathrm{~ns}$ \\
C.V. (\%) & 16,50 & 24,17 & 18,63 & 24,25 & 24,57 \\
\hline
\end{tabular}

$* *$ significativo a $1 \%$ de probabilidade

* significativo a $5 \%$ de probabilidade

ns não significativo

Tabela 45. Equações de regressão, coeficientes de determinação $\left(R^{2}\right)$, pontos de mínimo $(\mathrm{Pm})$ do teor percentual de enxofre $(\%=y)$ nas diversas partes das plantas em função das idades (meses $=x$ ).

\begin{tabular}{|c|c|c|c|c|}
\hline \multirow{2}{*}{$\begin{array}{l}\text { Partes } \\
\text { da planta }\end{array}$} & \multirow{2}{*}{$\begin{array}{c}\text { Equações } \\
y=\end{array}$} & \multirow{2}{*}{$\mathrm{R}^{2}$} & \multicolumn{2}{|c|}{ Ponto de mínimo } \\
\hline & & & $\mathrm{x}$ & $y$ \\
\hline $\begin{array}{l}\text { Folhas } \\
\text { Ramos } \\
\text { Caule-ponta } \\
\text { Caule-meio } \\
\text { Caule-base }\end{array}$ & $\begin{array}{l}0,52246-0,00754 x+0,00005 x^{2} \\
0,13017-0,00322 x+0,00002 x_{2}^{2} \\
0,11322-0,00322 x+0,00002 x^{2} \\
0,14251-0,00389 x+0,00003 x^{2} \\
0,08229-0,00151 x+0,00001 x^{2}\end{array}$ & $\begin{array}{l}93,46 * * \\
91,90 * * \\
80,62 * * \\
98,80 * * \\
92,82 *\end{array}$ & $\begin{array}{l}72 \\
63 \\
72 \\
72 \\
63\end{array}$ & $\begin{array}{l}0,25 \\
0,03 \\
0,001 \\
0,002 \\
0,03\end{array}$ \\
\hline
\end{tabular}

$* *$ significativo a $1 \%$ de probabilidade

* significativo a $5 \%$ de probabilidade 
Verifica-se através da Tabela 45 que as concentraçöes de enxofre em todas as partes estudadas foram ajus tadas por equações de regressão quadräticas, com mínimos de concentração de $0,25 \%$ aos 72 meses de idade para folhas; $0,03 \%$ aos 63 meses para ramos; $0,001 \%$ aos 72 meses para ponta do caule; $0,002 \%$ aos 72 meses para meio do caule e $0,03 \%$ aos 63 meses de idade para base do:caule.

Aos 24 e 96 meses de idade, as concentrações es timadas de enxofre na planta, foram de $0,37 \%$ e $0,28 \%$ para fo1 has ; $0,07 \%$ e $0,06 \%$ para ramos; $0,05 \%$ e $0,01 \%$ para ponta do caule; $0,06 \%$ e $0,02 \%$ para meio do caule e $0,05 \%$ e $0,04 \%$ para base do caule. Confrontando-se com os teores encontrados em plantas deficientes (folhas superiores $0,09 \%$; folhas inferiores $0,11 \%$; ramos $0,06 \%$ e caule $0,04 \%$ ) observa-se que os valores para folhas e ramos estimados para plantas com 24 meses es tão acima daqueles correspondentes às plantas deficientes, sen do que para caule a concentração está no limite. Para plantas com 96 meses de idade, a concentração estimada para folhas es tá acima do limite de carência, para ramos semelhantes e para caule estes valores estão abaixo.

\section{b) Acūmu 10}

Os dados de acümulo de enxofre nas diversas par tes da planta e planta inteira, em função da idade e resumo da anālise de variância, acham-se na Tabela 46 , enquanto queas 
equações de regressão, coeficientes de determinação e pontos de mínimo são apresentados na Tabela 47 .

Observa-se pela Tabela 46, que houve diferenças entre as partes e na planta inteira no acūmulo de enxofre, embora essas diferenças não tenham sido significativas nas primeiras idades, tornando-se mais expressivas aos 96 meses de idade.

Para ramos verifica-se que equação de 19 grau com alto coeficiente de determinação ajustou-se ao acréscimo linear do acúmulo de enxofre, mostrando que a quantidade aumenta com a idade da planta (Tabela 47).

No caso de folhas, ponta, meio e base do caule, assim como para planta inteira, ajustaram-se equações de regressão quadráticas no acūmulo do elemento com mínimos de 6,21 $g$ aos 24 meses para folhas; $0,18 \mathrm{~g}$ aos 21 meses para ponta do caule; $0,51 \mathrm{~g}$ aos 29 meses para meio do caule; 0,61 g aos 27 meses para base do caule e $9,47 \mathrm{~g}$ aos 27 meses para planta in teira.

Constatou-se aos 24 e 96 mesés de idade acú mulos estimados de 3,71 e $2,80 \mathrm{~g}$ de S/kg de folhas; 0;70 e $0,60 \mathrm{~g}$ de S/kg de ramos; 0,50 e $0,10 \mathrm{~g}$ de $\mathrm{s} / \mathrm{kg}$ de ponta do caule; 0,65 e 0,20 g de S/kg de méio do caule e 0,53 e 0,44 g de $\mathrm{S} / \mathrm{kg}$ de base do caule.

As plantas mostraram aos 24 e 96 meses de idade acūmulos estimados de enxofre (g/planta) em 6,21 e 28,74 g para folhas; 0,44 e $12,53 \mathrm{~g}$ para ramos; 0,18 e $1,91 \mathrm{~g}$ para 
Tabela 46. Quantidades de enxofre (g) acumuladas nas diversas partes da planta em função das idades (Média de 5 repetições)

\begin{tabular}{|c|c|c|c|c|c|c|}
\hline \multirow{2}{*}{$\begin{array}{l}\text { Idade } \\
\text { (meses) }\end{array}$} & \multirow{2}{*}{ Folhas } & \multirow{2}{*}{ Ramos } & \multicolumn{3}{|c|}{ Caule } & \multirow{2}{*}{ Tota1 } \\
\hline & & & Ponta & Meio & Base & \\
\hline $\begin{array}{l}24 \\
36 \\
48 \\
96\end{array}$ & $\begin{array}{c}6,67 b c \\
5,74 c \\
9,42 b \\
28,69 a\end{array}$ & $\begin{array}{r}1,45 \mathrm{~b} \\
3,24 \mathrm{~b} \\
1,95 \mathrm{~b} \\
13,24 \mathrm{a}\end{array}$ & $\begin{array}{l}0,23 b c \\
0,11 c \\
0,49 b \\
1,90 a\end{array}$ & $\begin{array}{l}0,56 \mathrm{~b} \\
0,50 \mathrm{~b} \\
0,97 \mathrm{~b} \\
5,87 \mathrm{a}\end{array}$ & $\begin{array}{r}0,63 \mathrm{~b} \\
1,00 \mathrm{~b} \\
2,51 \mathrm{~b} \\
21,62 \mathrm{a}\end{array}$ & $\begin{array}{r}9,54 b \\
10,59 b \\
15,34 b \\
71,32 a\end{array}$ \\
\hline DMS (5\%) & 3,36 & 4,88 & 0,25 & 2,33 & 4,98 & 8,45 \\
\hline $\begin{array}{l}\text { Teste F } \\
\text { C.V. (\%) }\end{array}$ & $\begin{array}{c}170,53 * * \\
14,66\end{array}$ & $\begin{array}{l}21,31 * * \\
54,17\end{array}$ & $\begin{array}{c}172,67 * \\
20,52\end{array}$ & $\begin{array}{l}20,44 * * \\
65,08\end{array}$ & $\begin{array}{l}68,00 * * \\
42,74\end{array}$ & $\begin{array}{c}204,75 * * \\
17,46\end{array}$ \\
\hline
\end{tabular}

**. significativo a $1 \%$ de probabilidade

Tabela 47. Equações de regressão, coeficientes de determinação $\left(R^{2}\right)$, pontos de mínimo ( $\mathrm{Pm}$ ) das quantidades de enxofre $(\mathrm{g}=\mathrm{y})$ acumuladas nas diversas partes da planta em função das idades (meses $=x$ )

\begin{tabular}{lcccc} 
Partes & \multicolumn{2}{c}{$\begin{array}{c}\text { Equações } \\
\text { da planta }\end{array}$} & \multicolumn{2}{c}{ Ponto de mínimo } \\
\cline { 4 - 5 } & & & $\mathrm{R}$ & $\mathrm{y}$ \\
\hline Folhas & $8,6744-0,2065 x+0,0043 \mathrm{x}^{2}$ & $99,44 * *$ & 24 & 6,21 \\
Ramos & $-3,5946+0,1680 x$ & $90,85 * *$ & - & - \\
Caule-ponta & $0,3078-0,0126 x+0,0003 x^{2}$ & $98,61 * *$ & 21 & 0,13 \\
Caule-meio & $1,5144-0,0694 x+0,0012 x^{2}$ & $99,96 * *$ & 29 & 0,51 \\
Caule-base & $3,8795-0,2408 x+0,0044 x^{2}$ & $99,98 * *$ & 27 & 0,61 \\
\hline Total & $18,5667-0,6836 x+0,0128 x^{2}$ & $99,99 * *$ & 27 & 9,47 \\
\hline
\end{tabular}

** significativo a $1 \%$ de probabilidade 
ponta do caule; 0,53 e 5,87 g para meio do caule; 0,65 e 21,62 g para base do caule e 8,01 e 70,67 g para planta inteira.

\subsubsection{Micronutrientes}

\section{$4 \cdot 2 \cdot 3 \cdot 1$. Boro}

a) Concentração

os resultados analíticos sobre a concentração de boro nas diversas partes da planta, encontram-se nas, Tabe1 as 48 e 49.

Verifica-se que houve efeito da concentraçãode boro nas diversas partes da planta (Tabela 48) em função das idades, sendo esses teores mais elevados nas plantas com 24 meses quando comparadas às das demais idades, que embora não apresentem diferenças entre si, mostram uma tendência a diminuir gradativamente a concentração conforme foi observado até a idade de 96 meses.

Pela Tabela 49 observa-se que os teores de bo ro nas folhas e ponta do caule ajustaram-se a equações de regressão de 10 grau, mostrando que a concentração do elemento diminui linearmente com o desenvolvimento da planta.

$$
\text { Para ramos, meio e base do caule ajustaram - se }
$$
equações de regressão quadrāticas, com um mínimo de concentração de 11,6 ppm aos 74 meses para ramos; 7,6ppm aos 73 meses para meio do caule e 6,1 ppm aos 70 meses de idade para base do caule. 
Tabela 48. Teor em ppm de boro contido na matéria seca das diversas partes da planta em função das idades (Mèdia de 5 repetições).

\begin{tabular}{|c|c|c|c|c|c|}
\hline \multirow{2}{*}{$\begin{array}{l}\text { Idade } \\
\text { (meses) }\end{array}$} & \multirow{2}{*}{ Folhas } & \multirow{2}{*}{ Ramos } & \multicolumn{3}{|c|}{ Caule } \\
\hline & & & Ponta & Meio & Base \\
\hline $\begin{array}{l}24 \\
36 \\
48 \\
96\end{array}$ & $\begin{array}{l}81,2 \mathrm{a} \\
64,8 \mathrm{ab} \\
70,8 \mathrm{ab} \\
53,8 \mathrm{c}\end{array}$ & $\begin{array}{l}17,6 \mathrm{a} \\
14,2 \mathrm{~b} \\
13,6 \mathrm{~b} \\
12,6 \mathrm{~b}\end{array}$ & $\begin{array}{l}15,6 \mathrm{a} \\
12,8 \mathrm{ab} \\
12,8 \mathrm{ab} \\
11,0 \mathrm{~b}\end{array}$ & $\begin{array}{r}17,4 \mathrm{a} \\
11,2 \mathrm{~b} \\
11,0 \mathrm{~b} \\
9,6 \mathrm{~b}\end{array}$ & $\begin{array}{r}12,8 \mathrm{a} \\
8,6 \mathrm{~b} \\
8,2 \mathrm{~b} \\
8,0 \mathrm{~b}\end{array}$ \\
\hline DMS (5\%) & 16,8 & 2,8 & 2,8 & 2,7 & 2,4 \\
\hline $\begin{array}{l}\text { Teste } \mathrm{F} \\
\text { C.V. }(5 \%)\end{array}$ & $\begin{array}{l}8,37 * * \\
13,8\end{array}$ & $\begin{array}{l}9,80 * * \\
10,68\end{array}$ & $\begin{array}{c}7,44 * x \\
11,93\end{array}$ & $\begin{array}{l}27,42 * * \\
12,05\end{array}$ & $\begin{array}{l}14,44 * * \\
14,27\end{array}$ \\
\hline
\end{tabular}

** significativo a $1 \%$ de probabilidade

Tabela 49. Equações de regressão, coeficientes de determinação $\left(R^{2}\right)$, pontos de mínimo (Pm) do teor em $\mathrm{ppm}$ de boro ( $\mathrm{ppm}=\mathrm{y}$ ) nas diversas partes da planta, em função das idades (meses $=x$ ).

\begin{tabular}{|c|c|c|c|c|}
\hline \multirow{2}{*}{$\begin{array}{l}\text { Partes } \\
\text { da planta }\end{array}$} & \multirow{2}{*}{$\begin{array}{c}\text { Equações } \\
y=\end{array}$} & \multirow{2}{*}{$\mathrm{R}^{2}$} & \multicolumn{2}{|c|}{ Ponto de mínimo } \\
\hline & & & $x$ & $y$ \\
\hline $\begin{array}{l}\text { Folhas } \\
\text { Ramos } \\
\text { Caule-ponta } \\
\text { Caule-meio } \\
\text { Caule-base }\end{array}$ & $\begin{array}{l}83,9638-0,3199 x \\
24,0414-0,3346 x+0,0022 x^{2} \\
15,7228-0,0524 x \\
27,8463-0,5545 x+0,0038 x^{2} \\
20,5487-0,4096 x+0,0029 x^{2}\end{array}$ & $\begin{array}{l}77,70 * * \\
94,44 * * \\
75,78 * * \\
88,75 * * \\
90,47 * *\end{array}$ & $\begin{array}{l}- \\
74 \\
73 \\
70\end{array}$ & $\begin{array}{c}- \\
11,6 \\
7,6 \\
6,1\end{array}$ \\
\hline
\end{tabular}

** significativo a $1 \%$ de probabilidade 
Aos 24 e 96 meses de idade as concentrações es timadas de boro foram 76,3 e 53,2 ppm para folhas; 17,3 e 12,6 ppm para ramos; 14,5 e 10,7ppm para ponta do caule; 16,7 e 9,7 ppm para meio do caule e 12,4 e 8,0 ppm para base do cau1 e.

b) Acūmu 10

As quantidades de boro acumuladas pelas diversas partes e pela planta inteira, em função da idade, e resumo da anālise de variância encontram-se na Tabela 50, enquanto que as equações de regressão, coeficientes de determinação e pontos de minimo na Tabela 51 .

Observa-se que houve efeito no acúmulo de boro nas diversas partes da planta, bem como na planta inteira, em função das idades, com um aumento gradativo nas primeiras ida des embora não tenham mostrado diferenças significativas entre si, tornando-se bastante acentuadas aos 96 meses de idade (Tabela 50).

Pela Tabela 51 constata-se que as folhas, pon ta, meio e base do caule, assim como a planta inteira, acumula ram boro obedecendo equações de regressão quadráticas com mínimos de $113,6 \mathrm{mg}$ aos 8 meses para folhas; $5,0 \mathrm{mg}$ aos 20 meses para ponta do caule; $12,0 \mathrm{mg}$ aos 22 meses para meio do caule; $13,2 \mathrm{mg}$ aos 23 meses para base do caule e $201,8 \mathrm{mg}$ aos 17 meses de idade para planta inteira.

Para ramos acumularam boro segundo uma equa- 
Tabela 50. Quantidades de boro (mg) acumuladas nas diversas partes daplan ta em função das idades (Mèdia de 5 repetições).

\begin{tabular}{|c|c|c|c|c|c|c|}
\hline \multirow{2}{*}{$\begin{array}{l}\text { Idade } \\
\text { (meses) }\end{array}$} & \multirow{2}{*}{ Folhas } & \multirow{2}{*}{ Ramos } & \multicolumn{3}{|c|}{ Caule } & \multirow{2}{*}{ Tota1 } \\
\hline & & & Ponta & Meio & Base & \\
\hline $\begin{array}{l}24 \\
36 \\
48 \\
96\end{array}$ & $\begin{array}{l}144,0 \mathrm{c} \\
121,1 \mathrm{c} \\
229,2 \mathrm{~b} \\
558,2 \mathrm{a}\end{array}$ & $\begin{array}{r}36,2 \mathrm{~b} \\
109,2 \mathrm{~b} \\
67,9 \mathrm{~b} \\
298,9 \mathrm{a}\end{array}$ & $\begin{array}{r}6,9 \mathrm{~b} \\
10,5 \mathrm{~b} \\
34,6 \mathrm{~b} \\
208,6 \mathrm{a}\end{array}$ & $\begin{array}{r}14,8 \mathrm{~b} \\
16,6 \mathrm{~b} \\
53,3 \mathrm{~b} \\
317,0 \mathrm{a}\end{array}$ & $\begin{array}{r}15,6 \mathrm{c} \\
18,9 \mathrm{c} \\
58,4 \mathrm{~b} \\
367,7 \mathrm{a}\end{array}$ & $\begin{array}{r}217,5 c \\
276,3 c \\
443,4 b \\
1750,4 a\end{array}$ \\
\hline DMS (5\%) & 83,6 & 100,9 & 33,6 & 61,9 & 31,6 & 130,6 \\
\hline $\begin{array}{l}\text { Teste } \mathrm{F} \\
\text { C.V. (\%) }\end{array}$ & $\begin{array}{c}157,46 * * \\
13,68\end{array}$ & $\begin{array}{l}22,35 * * \\
43,49\end{array}$ & $\begin{array}{l}134,36 * * \\
28,50\end{array}$ & $\begin{array}{l}90,48 * * \\
34,03\end{array}$ & $\begin{array}{l}472,47 * * \\
15,14\end{array}$ & $\begin{array}{c}505,87 * * \\
10,73\end{array}$ \\
\hline
\end{tabular}

$* *$ significativo a $1 \%$ de probabilidade

Tabela 51. Equações de regressão, coeficientes de determinação $\left(R^{2}\right)$, pontos de mínimo $(\mathrm{Pm})$ das quantidades de boro ( $\mathrm{mg}=\mathrm{y}$ ) acumuladas nas diversas partes da planta em função das idades (meses $=x$ ).

\begin{tabular}{lccccc}
$\begin{array}{l}\text { Partes } \\
\text { da planta }\end{array}$ & $\begin{array}{c}\text { Equações } \\
\mathrm{y}=\end{array}$ & $\mathrm{R}^{2}$ & \multicolumn{2}{c}{ Ponto de mínimo } \\
\cline { 3 - 5 } & & & $\mathrm{x}$ & $\mathrm{y}$ \\
\hline Folhas & $117,2867-0,9239 x+0,0576 \mathrm{x}^{2}$ & $98,19 * *$ & 8 & 113,6 \\
Ramos & $-53,3944-3,5577 x$ & $90,93 * *$ & - & - \\
Caule-ponta & $19,3270-1,4245 x+0,0354 x^{2}$ & $99,92 * *$ & 20 & 5,0 \\
Caule-meio & $39,4453-2,4753 x+0,0559 x^{2}$ & $99,90 * *$ & 22 & 12,0 \\
Caule-base & $48,3543-3,0579 x+0,0665 x^{2}$ & $99,93 * *$ & 23 & 13,2 \\
\hline Total & $278,4368-8,7687 x+0,2511 x^{2}$ & $99,98 * *$ & 17 & 201,8 \\
\hline
\end{tabular}

** significativo a $1 \%$ de probabilidade 
ção linear, aumento e quantidade do elemento com a idade da p 1 anta.

Aos 24 e 96 meses de idade, observou-se acūmu los estimados de 76,3 e $53,2 \mathrm{mg}$ de $B / \mathrm{kg}$ de folhas; 17,3 e $12,6 \mathrm{mg}$ de B/kg de ramos; 14,5 e $10,7 \mathrm{mg}$ de B/kg de ponta do caule; 16,7 e $9,7 \mathrm{mg}$ de B/kg de meio do caule e 12,4 e $8,0 \mathrm{mg}$ de $B / k g$ de base do caule.

As plantas mostraram aós 24 e 96 meses acúmulos estimados de boro (mg/planta) para folhas em 128,3 e 559,7 mg; para ramos 31,9 e $288,1 \mathrm{mg}$; para ponta 5,5 e 208,8 mg; pa ra meio 12,2 e $317,3 \mathrm{mg}$; para base do caule 13,3 e 368,0 mg e para planta inteira 191,2 e $1741,9 \mathrm{mg}$.

\subsubsection{Cobre}

\section{a) Concentração}

Os resultados analíticos referentes à concentração de cobre nas diversas partes da planta, em função das idades, encontram-se nas Tabelas 52 e 53.

Pela anälise dos dados observa-se que houve diferenças nas concentrações de cobre em função das idades, pạ ra todas as partes estudadas (Tabela 52).

Verifica-se pela Tabela 53, que os teores de cobre parafolhas, caule, ponto, meio e base do caule ajustaram-se a equações de regressão quadräticas, com mínimos de concentração para folhas de 12,2 ppm aos 53 meses de idade, 
Tabela 52. Teor em ppm de cobre contido na matéria seca das diversas partes da planta em função das idades (Médias de 5 repetiçöes).

\begin{tabular}{|c|c|c|c|c|c|}
\hline \multirow{2}{*}{$\begin{array}{l}\text { Idade } \\
\text { (meses) }\end{array}$} & \multirow{2}{*}{ Folhas } & \multirow{2}{*}{ Ramos } & \multicolumn{3}{|c|}{ Caule } \\
\hline & & & Ponta & Meio & Base \\
\hline $\begin{array}{l}24 \\
36 \\
48 \\
96\end{array}$ & $\begin{array}{l}19,0 \mathrm{~b} \\
17,0 \mathrm{~b} \\
11,0 \mathrm{c} \\
30,0 \mathrm{a}\end{array}$ & $\begin{array}{r}12,0 \mathrm{~b} \\
11,0 \mathrm{~b} \\
6,0 \mathrm{c} \\
20,0 \mathrm{a}\end{array}$ & $\begin{array}{c}10,0 \mathrm{a} \\
7,0 \mathrm{ab} \\
6,0 \mathrm{~b} \\
10,0 \mathrm{a}\end{array}$ & $\begin{array}{r}10,0 \mathrm{a} \\
10,0 \mathrm{a} \\
7,0 \mathrm{~b} \\
10,0 \mathrm{a}\end{array}$ & $\begin{array}{r}12,0 \mathrm{a} \\
12,0 \mathrm{a} \\
6,0 \mathrm{~b} \\
13,0 \mathrm{a}\end{array}$ \\
\hline DMS (5\%) & 5,9 & 3,8 & 3,2 & 2,5 & 4,7 \\
\hline $\begin{array}{l}\text { Teste F } \\
\text { C.V. (\%) }\end{array}$ & $\begin{array}{l}29,61 * * \\
16,93\end{array}$ & $\begin{array}{l}38,38 * * \\
17,03\end{array}$ & $\begin{array}{r}6,80 * * \\
21,42\end{array}$ & $\begin{array}{l}6,00 * * \\
14,80\end{array}$ & $\begin{array}{l}7,45 * * \\
24,39\end{array}$ \\
\hline
\end{tabular}

** significativo a $1 \%$ de probabilidade

Tabela 53. Equações de regressão, coeficientes de determinação $\left(R^{2}\right)$, pontos de mínimo ( $\mathrm{Pm}$ ) do teor em $\mathrm{ppm}$ de cobre ( $\mathrm{ppm}=\mathrm{y}$ ) nas diversas partes da planta, em função das idades (meses $=x$ ).

\begin{tabular}{llccc}
$\begin{array}{l}\text { Partes } \\
\text { da planta }\end{array}$ & \multicolumn{1}{c}{$\begin{array}{c}\text { Equações } \\
\mathrm{y}=\end{array}$} & & \multicolumn{2}{c}{ Ponto de mínimo } \\
\cline { 5 - 5 } & & & $\mathrm{R}$ & $\mathrm{y}$ \\
\hline Folhas & $38,3292-0,9934 x+0,0094 \mathrm{x}^{2}$ & $95,95 * *$ & 53 & 12,2 \\
Ramos & $26,3658-0,7301 x+0,0069 x^{2}$ & $93,96 * *$ & 53 & 7,1 \\
Caule-ponta & $18,0488-0,4266 x+0,0036 x^{2}$ & $90,22 * *$ & 60 & 5,3 \\
Caule-meio & $15,8170-0,2751 x+0,0022 x^{2}$ & $66,33 * *$ & 62 & 7,3 \\
Caule-base & $23,9634-0,5702 x+0,0047 x^{2}$ & $65,82 * *$ & 60 & 6,8 \\
\hline
\end{tabular}

** significativo a $1 \%$ de probabilidade 
ramos 7,1 ppm aos 53 meses, ponta do caule 5,3 ppm aos 60 me ses, meio do caule 7,3 ppm aos 62 meses e base do caule 6,8 ppm aos 60 meses de idade.

As concentraçöes estimadas de cobre aos 24 e 96 meses foram 19,9 e 29,9 ppm para folhas; 12,8 e 19,9 ppm para ramos; 9,9 e 10,0 ppm para ponta do caule; 10,5e 9,9ppm pa ra meio do caule e 13,0 e 12,9 ppm para base do caule.

\section{b) Açùnu 10}

Nas Tabelas 54 e 55 acham-se expostos os resul tados analíticos sobre o acumulo de cóbre nas diversas partes e na planta inteira em função das idades.

Observarse pela Tabela 54 que houve diferenças entre as partes e planta inteira no acümulo de cobre, embora essas diferenças não tenham sido expressivas nas prime ras idades.

0 acümulo de cobre nas diversas partes e na planta inteira obedeceram a equações quadräticas com mínimos de $26,6 \mathrm{mg}$ aos 35 meses para folhas; $35,7 \mathrm{mg}$ aos 33 meses para ramos; $3,3 \mathrm{mg}$ aos 30 meses para ponta do caule; $8,4 \mathrm{mg}$ aos 28 meses para meio do caule; $11,5 \mathrm{mg}$ aos 31 meses para base do caule e $87,3 \mathrm{mg}$ aos 32 meses de idade para planta inteira ( Tabela 55).

Aos 24 e 96 meses de idade, observou-se um acū mulo estimado de 19,9 e $29,9 \mathrm{mg}$ de Cu/kg de folhas; 12,8 e $19,9 \mathrm{mg}$ de Cu/kg de ramos; 9,9 e $10,0 \mathrm{mg}$ de Cu/kg de ponta do 
Tabela 54. Quantidades de cobre (mg) acumuladas nas diversas partes da planta em função das idades (Média de 5 repetições).

\begin{tabular}{|c|c|c|c|c|c|c|}
\hline \multirow{2}{*}{$\begin{array}{l}\text { Idade } \\
\text { (meses) }\end{array}$} & \multirow{2}{*}{ Folhas } & \multirow{2}{*}{ Ramos } & \multicolumn{3}{|c|}{ Caule } & \multirow{2}{*}{ Total } \\
\hline & & & Ponta & Meio & Base & \\
\hline $\begin{array}{l}24 \\
36 \\
48 \\
96\end{array}$ & $\begin{array}{r}33,6 \mathrm{~b} \\
32,1 \mathrm{~b} \\
35,9 \mathrm{~b} \\
309,0 \mathrm{a}\end{array}$ & $\begin{array}{r}24,3 \mathrm{~b} \\
84,7 \mathrm{~b} \\
30,3 \mathrm{~b} \\
464,6 \mathrm{a}\end{array}$ & $\begin{array}{c}4,4 \mathrm{~b} \\
5,94 \mathrm{~b} \\
16,5 \mathrm{~b} \\
190,2 \mathrm{a}\end{array}$ & $\begin{array}{r}8,5 b \\
14,8 b \\
33,8 b \\
309,0 a\end{array}$ & $\begin{array}{r}14,7 \mathrm{~b} \\
26,0 \mathrm{~b} \\
43,0 \mathrm{~b} \\
605,9 \mathrm{a}\end{array}$ & $\begin{array}{r}85,5 b \\
163,5 b \\
159,5 b \\
1898,7 \mathrm{a}\end{array}$ \\
\hline DMS (5\%) & 33,9 & 117,1 & 22,4 & 30,2 & 154,5 & 192,5 \\
\hline $\begin{array}{l}\text { Teste F } \\
\text { C.V. (\%) }\end{array}$ & $\begin{array}{c}269,32 * x \\
18,26\end{array}$ & $\begin{array}{l}53,12 * * \\
42,84\end{array}$ & $\begin{array}{c}269,52 * * \\
22,78\end{array}$ & $\begin{array}{c}379,23 * * 6 \\
18,23\end{array}$ & $\begin{array}{l}57,47 * * \\
49,47\end{array}$ & $\begin{array}{c}344,44 * * \\
18,42\end{array}$ \\
\hline
\end{tabular}

** significativo a $1 \%$ de probabilidade

Tabela 55. Equações de regressão, coeficientes de determinação ( $R^{2}$ ), pontos de mínimo (Pm) das quantidades de cobre ( $\mathrm{mg}=\mathrm{y}$ ) acumula das nas diversas partes da planta em função das idades (me= ses $=\mathrm{x}$ ).

\begin{tabular}{lcccc}
\hline & \multicolumn{1}{c}{$\begin{array}{c}\text { Equações } \\
\text { Partes } \\
\text { da planta }\end{array}$} & \multicolumn{2}{c}{$\mathrm{R}^{2}$} & \multicolumn{2}{c}{ Ponto de mínimo } \\
\cline { 3 - 5 } & & & $\mathrm{x}$ & $\mathrm{y}$ \\
\hline Folhas & $120,1248-5,3342 x+0,0760 x^{2}$ & $99,91 * *$ & 35 & 26,6 \\
Ramos & $151,6603-7,0484 x+0,1071 x^{2}$ & $97,30 * *$ & 33 & 35,7 \\
Caule-ponta & $41,9271-2,5742 x+0,0429 x^{2}$ & $99,98 * *$ & 30 & 3,3 \\
Caule-meio & $57,7987-3,5647 x+0,0643 x^{2}$ & $99,98 * *$ & 28 & 8,4 \\
Caule-base & $153,3584-9,0021 x+0,1428 x^{2}$ & $99,90 * *$ & 31 & 11,5 \\
\hline Total & $531,4497-27,9238 x+0,4389 x^{2}$ & 99,68 & 32 & 87,3 \\
\hline
\end{tabular}

$* *$ significativo a $1 \%$ de probabilidade 
caule; 10,5 e $9,9 \mathrm{mg}$ de Cu/kg de meio do caule e 13,0 e 12,9 mg de Cu/kg de base do caule.

Os acümulos estimados para quantidades de cobre em mg/planta aos 24 e 96 meses de idade foram respectivamente de 35,9 e $308,8 \mathrm{mg}$ para folhas; 44,2 e 462,6 mg para ra mos; 4,8 e 190,1 mg para ponta do caule; 9,3 e 308,9 mg para meio do caule; 19,6 e 605,4 mg para base do caule e 113,8 e $1875,8 \mathrm{mg}$ para planta inteira.

$4 \cdot 2 \cdot 3 \cdot 3 \cdot$ Ferro

a) Concentração

Os dados analíticos referentes às concentrações de ferro nas diversas partes da planta em função das idades, encontram-se nas Tabelas 56 e 57 .

Observa-se atravēs da Tabela 56 que com exceção da base do caule, houve diferenças nas. concentrações de ferro em função das idades para as demais partes da planta, sendo que as concentrações mais altas ocorreram nas follhas.

As concentrações de ferro nas folhas, ramos e base do caule, foram influenciadas significativamente. pela idade das plantas, havendo um decréscimo no teor do nutriente segundo equações de regressão lineares (Tabela 57).

Nesta mesma tabela verifica-se que os teores de ferro na ponta e meio do caule obedeceram a equações de regressão quadräticas, apresentando teores mínimos de 18,3 
Tabela 56. Teor em ppm de ferro contido na matēria seca das diversas partes da planta em função das idades (Média de 5 repetições).

\begin{tabular}{|c|c|c|c|c|c|}
\hline \multirow{2}{*}{$\begin{array}{c}\text { Idade } \\
\text { (meses) }\end{array}$} & \multirow{2}{*}{ Folhas } & \multirow{2}{*}{ Ramos } & \multicolumn{3}{|c|}{ Caule } \\
\hline & & & Ponta & Meio & Base \\
\hline $\begin{array}{l}24 \\
36 \\
48 \\
96\end{array}$ & $\begin{array}{r}257,0 \mathrm{a} \\
140,0 \mathrm{~b} \\
176,0 \mathrm{~b} \\
57,0 \mathrm{c}\end{array}$ & $\begin{array}{l}65,0 a \\
49,0 a \\
50,0 a \\
43,0 a\end{array}$ & $\begin{array}{l}54,0 \mathrm{a} \\
25,0 \mathrm{~b} \\
32,0 \mathrm{~b} \\
28,0 \mathrm{~b}\end{array}$ & $\begin{array}{l}49,0 \mathrm{a} \\
41,0 \mathrm{a} \\
26,0 \mathrm{~b} \\
19,0 \mathrm{~b}\end{array}$ & $\begin{array}{l}69,0 \mathrm{a} \\
82,0 \mathrm{a} \\
39,0 \mathrm{~b} \\
25,0 \mathrm{~b}\end{array}$ \\
\hline DMS (5\%) & 52,2 & 23,1 & 11,4 & 10,4 & 21,3 \\
\hline $\begin{array}{l}\text { Teste } \mathrm{F} \\
\text { C.V. (\%) }\end{array}$ & $\begin{array}{l}41,31 * * \\
18,32\end{array}$ & $\begin{array}{c}2,69 \mathrm{~ns} \\
24,63\end{array}$ & $\begin{array}{l}21,95 * * \\
18,05\end{array}$ & $\begin{array}{l}28,31 * * \\
17,05\end{array}$ & $\begin{array}{l}23,31 * * \\
22,44\end{array}$ \\
\hline
\end{tabular}

** significativo a $1 \%$ de probabilidade

ns não significativo

Tabela 57. Equações de regressão, coeficientes de determinação $\left(R^{2}\right)$, pontos de mínimo ( $\mathrm{Pm}$ ) do teor em $\mathrm{ppm}$ de ferro ( $\mathrm{ppm}=\mathrm{y}$ ) nas diver sas partes da planta em função das ịdades (meses $=x$ ).

\begin{tabular}{|c|c|c|c|c|}
\hline \multirow{2}{*}{$\begin{array}{l}\text { Partes } \\
\text { da planta }\end{array}$} & \multirow{2}{*}{$\begin{array}{c}\text { Equaçöes } \\
y=\end{array}$} & \multirow{2}{*}{$\mathrm{R}^{2}$} & \multicolumn{2}{|c|}{ Ponto de mínimo } \\
\hline & & & $x$ & $y$ \\
\hline $\begin{array}{l}\text { Folhas } \\
\text { Ramos } \\
\text { Caule-ponta } \\
\text { Caule-meio } \\
\text { Caule-base }\end{array}$ & $\begin{array}{l}277,0120-2,3434 x \\
63,7831-0,2359 x \\
90,9268-2,0759 x+0,0148 x^{2} \\
84,5000-1,6685 x+0,0102 x^{2} \\
85,7831-0,6526 x\end{array}$ & $\begin{array}{l}79,46 * * \\
63,30 * \\
67,15 * * \\
97,01 * * \\
65,56 * *\end{array}$ & $\begin{array}{r}- \\
70 \\
81 \\
-\end{array}$ & $\begin{array}{c}- \\
- \\
18,3 \\
16,6 \\
-\end{array}$ \\
\hline
\end{tabular}

**: significativo a $1 \%$ de probabilidade

* significativo a $5 \%$ de probabilidade 
ppm aos 70 meses para ponta do caule e de 16,6 ppm aos 81 meses de idade para meio do caule.

Aos 24 e 96 meses de idade as concentrações es timadas de ferro para folhas foram 220,8 e 52,0 ppm; para ramos 58,1 e 41,1 ppm; para ponta do caule 49,6 e 28,4 ppm; para meio do caule 50,4 e 18,9 ppm e para base do caule 70,1 e $23,1 \mathrm{ppm}$.

b) Acúmu 10

As quantidades de ferro acumuladas pelas dive $\underline{r}$ sas partes da planta. e na planta inteira, em função das ida des e o resumo da anālise de variância encontram-se na Tabela 58 enquanto que as equações de regressão, coeficientes de determinação e pontos de mínimo acham-se na Tabela 59.

Através da Tabela 58 verifica-se que houve dị ferenças no acūmulo de ferro em função das idades para todas as partes e planta inteira, sendo esses acúmulos mais acentua dos aos 96 meses quando comparados com as demais idades.

As folhas, ramos e base do caule acumularamfer ro com a maturidade das plantas havendo um aumento na quantidade do elemento de forma linear (Tabela 59).

Para ponta e meio do caule, assim como para a planta

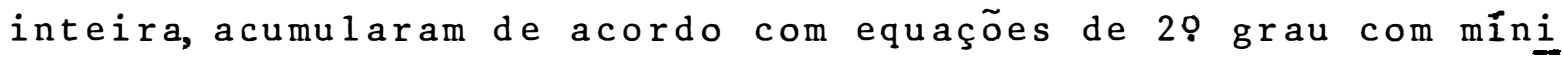
nimos de $17,7 \mathrm{mg}$ aos 23 meses para ponta do caule; $35,3 \mathrm{mg}$ aos 18 meses para meio do caule e $592,4 \mathrm{mg}$ aos 7 meses de ida de para planta inteira. 
Tabela 58. Quantidades de ferro (mg) acumuladas nas diversas partes da planta em função das idades (Média de 5 repetições).

\begin{tabular}{|c|c|c|c|c|c|c|}
\hline \multirow{2}{*}{$\begin{array}{c}\text { Idade } \\
\text { (meses) }\end{array}$} & \multirow{2}{*}{ Folhas } & \multirow{2}{*}{ Ramos } & \multicolumn{3}{|c|}{ Caule } & \multirow{2}{*}{ Total } \\
\hline & & & Ponta & Meio & Base & \\
\hline $\begin{array}{l}24 \\
36 \\
48 \\
96\end{array}$ & $\begin{array}{l}452,2 \mathrm{ab} \\
269,9 \mathrm{~b} \\
574,6 \mathrm{a} \\
595,8 \mathrm{a}\end{array}$ & $\begin{array}{r}133,6 \mathrm{~b} \\
375,3 \mathrm{~b} \\
259,1 \mathrm{~b} \\
1044,5 \mathrm{a}\end{array}$ & $\begin{array}{r}23,5 \mathrm{~b} \\
20,6 \mathrm{~b} \\
86,4 \mathrm{~b} \\
528,6 \mathrm{a}\end{array}$ & $\begin{array}{r}41,6 \mathrm{~b} \\
61,3 \mathrm{~b} \\
127,7 \mathrm{~b} \\
627,9 \mathrm{a}\end{array}$ & $\begin{array}{r}78,9 \mathrm{~b} \\
176,7 \mathrm{~b} \\
277,4 \mathrm{~b} \\
1138,8 \mathrm{a}\end{array}$ & $\begin{array}{c}729,8 \mathrm{c} \\
903,8 \mathrm{bc} \\
1325,2 \mathrm{~b} \\
3935,6 \mathrm{a}\end{array}$ \\
\hline DMS (5\%) & 198,4 & $514 ; 7$ & 106,4 & 108,4 & 419,6 & 690,0 \\
\hline $\begin{array}{l}\text { Teste F } \\
\text { C.V. (\%) }\end{array}$ & $\begin{array}{l}9,31 * * \\
23,15\end{array}$ & $\begin{array}{l}10,22 * x \\
62,71\end{array}$ & $\begin{array}{l}86,53 * * \\
35,66\end{array}$ & $\begin{array}{l}107,73^{*} * \\
27,90\end{array}$ & $\begin{array}{l}22,12 * * \\
55,42\end{array}$ & $\begin{array}{c}126,56 * * \\
17,24\end{array}$ \\
\hline
\end{tabular}

** significativo a $1 \%$ de probabilidade

Tabela 59. Equações de regressão, coeficientes de determinação $\left(R^{2}\right)$, pontos de mínimo ( $\mathrm{Pm}$ ) das quantidades de ferro ( $\mathrm{mg}=\mathrm{y}$ ) acumula das nas diversas partes da planta em função das idades (me= ses $=x$ ).

\begin{tabular}{|c|c|c|c|c|}
\hline \multirow{2}{*}{$\begin{array}{l}\text { Partes } \\
\text { da planta }\end{array}$} & \multirow{2}{*}{$\begin{array}{c}\text { Equações } \\
y=\end{array}$} & \multirow{2}{*}{$\mathrm{R}^{2}$} & \multicolumn{2}{|c|}{ Ponto de mínimo } \\
\hline & & & $\mathrm{x}$ & $y$ \\
\hline $\begin{array}{l}\text { Folhas } \\
\text { Ramos } \\
\text { Caule-ponta } \\
\text { Caule-meio } \\
\text { Caule-base }\end{array}$ & $\begin{array}{l}322,5001+2,9539 x \\
178,1856+12,3789 x \\
67,9567-4,3862 x+0,0957 x^{2} \\
65,9017-3,4441 x+0,0969 x^{2} \\
360,8667+15,2714 x\end{array}$ & $\begin{array}{l}38,86 * * \\
92,39 * * \\
99,83 * * \\
99,97 * * \\
97,80 * *\end{array}$ & $\begin{array}{r}- \\
\overline{2} \\
18 \\
-\end{array}$ & $\begin{array}{r}- \\
- \\
37,7 \\
-\end{array}$ \\
\hline Total & $614,1069-6,0590 x+0,4237 x^{2}$ & $99,95 * *$ & 7 & 592,4 \\
\hline
\end{tabular}

** significativo a $1 \%$ de probabilidade 
Constatou-se um acümulo estimado aos 24 e 96 meses de idade de 220,8 e $52,0 \mathrm{mg}$ de Fe/kg de folhas; 58,1 e $41,1 \mathrm{mg}$ de Fe/kg de ramos; 49,6 e $28,4 \mathrm{mg}$ de Fe/kg de ponta do caule; 50,4 e $18,9 \mathrm{mg}$ de Fe/kg de meio do caule e 70,1 e 23,1 mg de Fe/kg de base do caule.

Aos 24 e 96 meses os acūmulos estimados para quantidades de cobre em mg/planta foram respectivamente de 393,4 e $606,1 \mathrm{mg}$ para folhas; 118,9 e $1010,1 \mathrm{mg}$ para ramos; 17,8 e 529,2 mg para ponta do caule; 39,0 e 628,1 mg para meio do caule; 5,6 e $1105,1 \mathrm{mg}$ para base do caule e 574,7 e 3941,6 mg para planta inteira.

\subsubsection{Manganês}

a) Concentração

As concentrações de manganês acumuladas nas diversas partes da planta em função da idade e o resumo de anālise de variância encontram-se na Tabela 60 .

Observa-se que os teores médios de manganês nas folhas e ramos nãovariaram durante o período estudado, não havendo, portanto, influência da idade destas partes da planta na concentração do nutriente. Por outro lado, para ponta, meio e base do caule, as concentrações de cobre em função das idades foram representadas por equações de regressão superiores a 2 grau .

Aos 24 e 96 meses de idade, as concentraçõesob 
157.

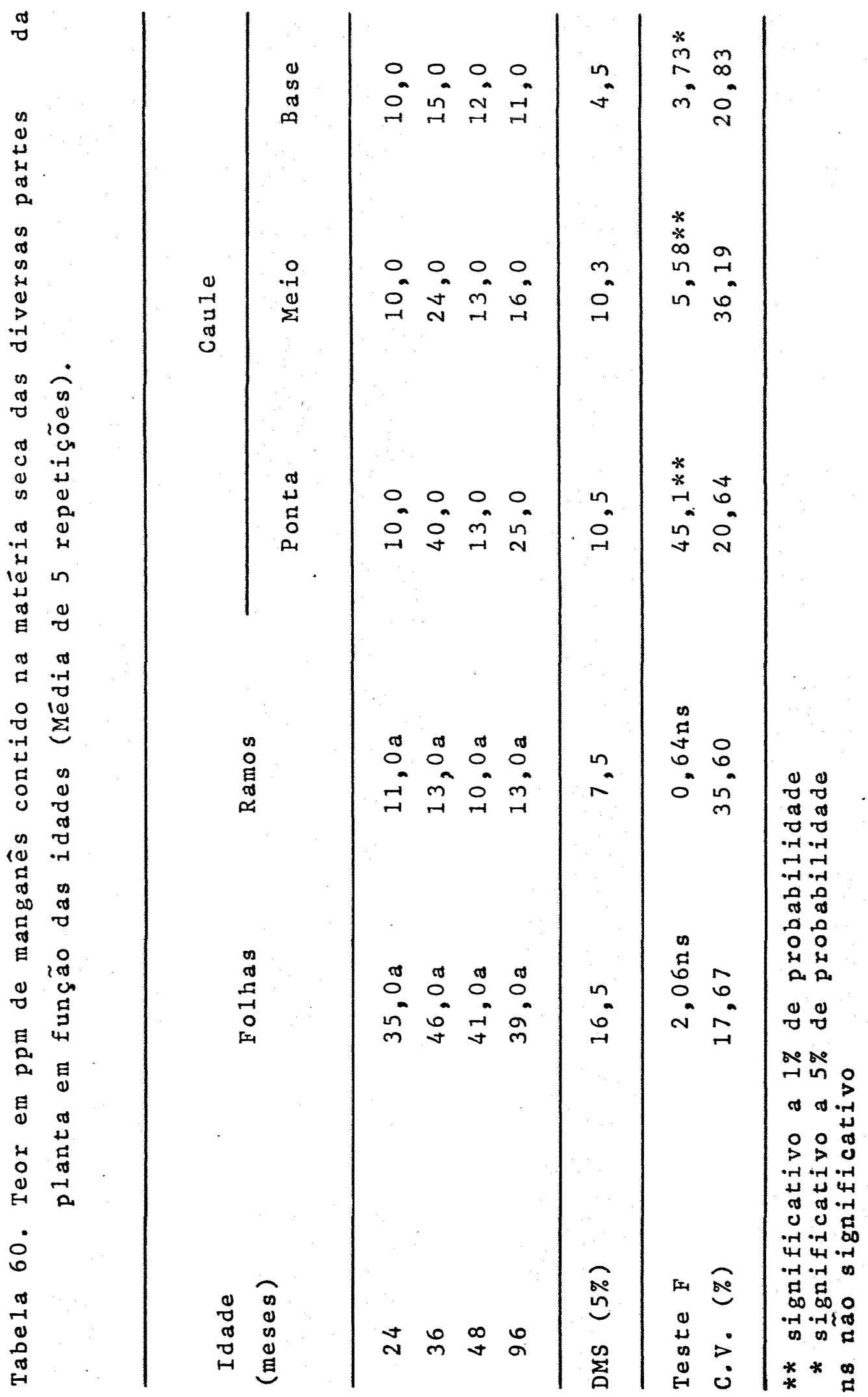


servadas de manganês foram 35,0 e 39,0 ppm para folhas; 11,0 e 13,0 ppm para ramos; 10,0 e 25,0 ppm para ponta do caule; 10,0 e 16,0 ppm para meio do caule e 10,0 e 11,0 para base do caule.

b) Acūmu 10

Os resultados analíticos referentes ao: acúmulo de manganês nas diversas partes e na planta inteira encontram se nas Tabelas 61 e 62 .

Pela análise de variância observa-se que houve diferenças no acúmulo de manganês em função das idades para as partes e planta inteira ( Tabela 61), sendo esses acúmulos mais expressivos aos 96 meses quando comparados com as outras idades .

Nas folhas, as quantidades acumuladas de mangą nês ajustou-se a uma regressão linear observando-se acréscimos com idade da planta (Tabela 62).

Para as demais partes e a planta inteira as acumulações crescentes ajustaram-se a equações de regressão quadráticas como altos coeficientes de determinação com mínimos de $31,7 \mathrm{mg}$ aos 12 meses para ramos; $9,4 \mathrm{mg}$ aos 29 meses para ponta do caule; $12,7 \mathrm{mg}$ aos 25 meses para meio do caule; $8,5 \mathrm{mg}$ aos 18 meses para base do caule e $129,5 \mathrm{mg}$ aos 21 meses de idade para planta inteira.

Constatou-se aos 24 e 96 meses de idade acúmu los observados de 35,0 e $39,0 \mathrm{mg}$ de Mn/kg de folhas 11,0 e 
Tabela 61. Quantidades de manganês (mg) acumuladas nas diversas partes da planta em função das idades (Média de 5 repetições).

\begin{tabular}{|c|c|c|c|c|c|c|}
\hline \multirow{2}{*}{$\begin{array}{l}\text { Idade } \\
\text { (meses) }\end{array}$} & \multirow{2}{*}{ Folhas } & \multirow{2}{*}{ Ramos } & \multicolumn{3}{|c|}{ Caule } & \multirow{2}{*}{ Total } \\
\hline & & & Ponta & Meio & Base & \\
\hline $\begin{array}{l}24 \\
36 \\
48 \\
96\end{array}$ & $\begin{array}{r}61,7 b \\
89,4 b \\
130,7 b \\
407,1 a\end{array}$ & $\begin{array}{c}22,2 \mathrm{c} \\
81,8 \mathrm{~b} \\
50,1 \mathrm{bc} \\
246,4 \mathrm{a}\end{array}$ & $\begin{array}{r}4,4 \mathrm{~b} \\
32,8 \mathrm{~b} \\
36,0 \mathrm{~b} \\
482,1 \mathrm{a}\end{array}$ & $\begin{array}{r}8,5 b \\
35,6 b \\
61,3 b \\
532,0 a\end{array}$ & $\begin{array}{r}12,2 \mathrm{~b} \\
32,8 \mathrm{~b} \\
83,8 \mathrm{~b} \\
513,2 \mathrm{a}\end{array}$ & $\begin{array}{r}109,9 c \\
272,4 b \\
361,9 b \\
2180,8 a\end{array}$ \\
\hline DMS (5\%) & 99,2 & 51,1 & 134,1 & 227,1 & 135,5 & 359,1 \\
\hline $\begin{array}{l}\text { Teste } \mathrm{F} \\
\text { C.V. (\%) }\end{array}$ & $\begin{array}{l}42,22 * * \\
31,78\end{array}$ & $\begin{array}{c}103,94 * * \\
22,00\end{array}$ & $\begin{array}{l}47,92 * * \\
53,35\end{array}$ & $\begin{array}{l}19,76 * * \\
78,70\end{array}$ & $\begin{array}{l}50,18 * * \\
46,61\end{array}$ & $\begin{array}{c}120,17 * * \\
27,11\end{array}$ \\
\hline
\end{tabular}

$* *$ significativo a $1 \%$ de probabilidade

Tabela 62. Equações de regressão, coeficientes de determinação $\left(R^{2}\right)$, pontos de mínimo $(\mathrm{Pm})$ das quantidades de manganês ( $\mathrm{mg}=\mathrm{y}$ ) acumuladas nas diversas partes da planta em função da idades (meses $=x$ ).

\begin{tabular}{|c|c|c|c|c|}
\hline \multirow{2}{*}{$\begin{array}{l}\text { Partes } \\
\text { da planta }\end{array}$} & \multirow{2}{*}{$\begin{array}{c}\text { Equações } \\
y=\end{array}$} & \multirow{2}{*}{$\mathrm{R}^{2}$} & \multicolumn{2}{|c|}{ Ponto de mínimo } \\
\hline & & & $x$ & $y$ \\
\hline $\begin{array}{l}\text { Folhas } \\
\text { Ramos } \\
\text { Caule-ponta } \\
\text { Caule-meio } \\
\text { Caule-base }\end{array}$ & $\begin{array}{l}-82,4017+4,9932 x \\
36,1844-0,7376 x+0,0303 x^{2} \\
97,6721-6,0918 x+0,1051 x^{2} \\
75,8949-5,0896 x+0,1025 x^{2} \\
36,2817-3,0424 x+0,0834 x^{2}\end{array}$ & $\begin{array}{l}98,07 * * \\
99,41 * * \\
99,66 * * \\
99,91 * * \\
99,99 * *\end{array}$ & $\begin{array}{l}- \\
12 \\
29 \\
25 \\
18\end{array}$ & $\begin{array}{r}- \\
31,7 \\
9,4 \\
12,7 \\
8,5\end{array}$ \\
\hline Total & $284,5027-14,9675 x+0,3614 x^{2}$ & $99,80 * *$ & 21 & 121,5 \\
\hline
\end{tabular}

** significativo a $1 \%$ de probabilidade 
$13,0 \mathrm{mg}$ de $\mathrm{Mn} / \mathrm{kg}$ de ramos; 10,0 e $25,0 \mathrm{mg}$ de $M n / k g$ de pontado caule; 10,0 e $16,0 \mathrm{mg}$ de Mn/kg de meio do caule e 10,0 e 11,0 mg de Mn/kg de base do caule.

Os acúmulos estimados para quantidades de manganês em mg/planta aos 24 e 96 meses de idade, foram respecti vamente de 37,4 e 396,9 mg para folhas; 35,9 e 245,0 mg para ramos; 11,9 e 481,3 mg para ponta do caule; 12,8 e 531,6 mg para meio do caule; 11,3 e $513,3 \mathrm{mg}$ para base do caule e 109,3 e $2168,1 \mathrm{mg}$ para planta inteira.

$$
4 \cdot 2 \cdot 3 \cdot 5 . \text { Zinco }
$$

a) Concentração

As concentrações de $z$ inco $n$ as diversas partes da planta em função das idades e o resumo de anālise de variância acham-se na Tabela 63 , enquanto que as equações de re gressão, coeficientes de determinação e pontos de mínimo na Tabe 1 a 64 .

Pela anālise de variância constata-se que hou ve diferenças nos teores de zinco em função das idades para folhas, ramos e base do caule, enquanto que para ponta e meio do caule não houve efeito da idade destas partes na concentração do nutriente (Tabela 63).

Para concentração de zinco nas folhas ajustou se uma equação de regressão de $10 \mathrm{grau}$ (Tabela 64) verificando-se um aumento no teor do nutriente com o desenvolvimento da planta. 
Tabela 63. Teor em ppm de zinco contido na matéria seca das diversas partes da planta em função das idades (Média de 5 repetições).

\begin{tabular}{llllll}
\hline \multirow{2}{*}{$\begin{array}{c}\text { Idade } \\
\text { (meses) }\end{array}$} & Folhas & Ramos & \multicolumn{3}{c}{ Caule } \\
\cline { 4 - 6 } & & & Ponta & Meio & Base \\
\hline 24 & $16,0 \mathrm{~b}$ & $36,0 \mathrm{a}$ & $15,0 \mathrm{a}$ & $15,0 \mathrm{a}$ & $14,0 \mathrm{a}$ \\
36 & $15,0 \mathrm{~b}$ & $19,0 \mathrm{~b}$ & $19,0 \mathrm{a}$ & $14,0 \mathrm{a}$ & $10,0 \mathrm{~b}$ \\
48 & $17,0 \mathrm{~b}$ & $25,0 \mathrm{bc}$ & $15,0 \mathrm{a}$ & $12,0 \mathrm{a}$ & $10,0 \mathrm{~b}$ \\
96 & $21,0 \mathrm{a}$ & $34,0 \mathrm{ab}$ & $19,0 \mathrm{a}$ & $16,0 \mathrm{a}$ & $11,0 \mathrm{~b}$ \\
\hline DMS (5\%) & 3,8 & 10,7 & 9,0 & 6,0 & 3,0 \\
\hline Teste $\mathrm{F}$ & $70,90 *$ & $9,00^{* *}$ & $1,77 \mathrm{~ns}$ & $1,37 \mathrm{~ns}$ & $7,16 * *$ \\
C.V. (\%) & 12,12 & 20,75 & 22,78 & 22,87 & 14,05 \\
\hline
\end{tabular}

$* *$ significativo a $1 \%$ de probabilidade

* significativo a $5 \%$ de probabilidade

ns não significativo

Tabela 64. Equações de regressão, coeficientes de determinação $\left(R^{2}\right)$, pon tos de mínimo $(\mathrm{Pm})$ do teor em ppm de zinco $(\mathrm{ppm}=\mathrm{y}$ ) contidos nas diversas partes da planta em função das idades (meses $=x$ ).

\begin{tabular}{|c|c|c|c|c|}
\hline \multirow{2}{*}{$\begin{array}{l}\text { Partes } \\
\text { da planta }\end{array}$} & \multirow{2}{*}{$\begin{array}{c}\text { Equaçōes } \\
y=\end{array}$} & \multirow{2}{*}{$\mathrm{R}^{2}$} & \multicolumn{2}{|c|}{ Ponto de mínimo } \\
\hline & & & $\mathbf{x}$ & $\mathrm{y}$ \\
\hline Folhas & $13,2048+0,0793 x$ & $90,59 * *$ & - & - \\
\hline Ramos & $5 \underset{\sim}{8}, 3292-1,3079 x+0,0110 x^{2}$ & $64,78 * *$ & 59 & 19,5 \\
\hline Caule-ponta & não significat. pelo teste $F$ & - & - & $\stackrel{-}{\prime}$ \\
\hline Caule-meio & não significat. pelo teste $F$ & - & - & - \\
\hline Caule-base & $21,1585-0,3865 x+0,0029 x^{2}$ & $71,95 * *$ & 66 & 8,4 \\
\hline
\end{tabular}

** significativo a $1 \%$ de probabilidade 
Ajustou-se equações de regressão quadräticas pä ra ramos e base do caule com concentração mínima de 19,5 ppm aos 59 meses para ramos e 8,4 ppm aos 66 meses de idade para base do caule.

As concentrações estimadas de zinco aos 24 e 96 meses de idade foram de 15,1 e 20,8 ppm para folhas; 33,3 e 34,4 ppm para ramos; 13,6 e 11,0 ppm para base do caule; enquanto que as concentrações observadas foram de 15,0 e 19,0 ppm para ponta do caule e 15,0 e 16,0 ppm para meio do caule.

b) Acūmu 10

Os dados analiticos referentes a acumulação dè zinco nas diversas partes das plantas em função das idades en contram-se nas Tabelas 65 e 66 .

Pela Tabela 65 observa-se que houve diferenças das quantidades acumuladas de zinco, para todas as partes e planta inteira, em função das idades, sendo essas diferenças mais acentuadas aos 96 meses de idade.

Para todas as partes estudadas, bem como para planta inteira, a acumulação de zinco obedeceu a equações de regressão de 2 o grau com mínimos $25,5 \mathrm{mg}$ aos 20 meses para fo 1has; $91,8 \mathrm{mg}$ aos 26 meses para ramos; $6,9 \mathrm{mg}$ aos 26 meses pa ra ponta do caule; $12,0 \mathrm{mg}$ aos 27 meses para meio do caule; $14,8 \mathrm{mg}$ aos 25 meses para base do caule e $152,5 \mathrm{mg}$ aos $26 \mathrm{me}-$ ses de idade para planta inteira (Tabela 66).

Verificourse um acúmulo estimado de zinco aos 
Tabela 65. Quantidades de zinco (mg) acumuladas nas diversas partes da planta em função das idades (Mẻdia de 5 repetições).

\begin{tabular}{|c|c|c|c|c|c|c|}
\hline \multirow{2}{*}{$\begin{array}{c}\text { Idade } \\
\text { (meses) }\end{array}$} & \multirow{2}{*}{ Folhas } & \multirow{2}{*}{ Ramos } & \multicolumn{3}{|c|}{ Caule } & \multirow{2}{*}{ Total } \\
\hline & & & Ponta & Meio & Base & \\
\hline $\begin{array}{l}24 \\
36 \\
48 \\
96\end{array}$ & $\begin{array}{r}28,3 \mathrm{c} \\
28,6 \mathrm{c} \\
54,9 \mathrm{~b} \\
216,9 \mathrm{a}\end{array}$ & $\begin{array}{r}73,8 \mathrm{~b} \\
150,3 \mathrm{~b} \\
131,5 \mathrm{~b} \\
780,2 \mathrm{a}\end{array}$ & $\begin{array}{r}6,6 \mathrm{~b} \\
15,6 \mathrm{~b} \\
41,3 \mathrm{~b} \\
367,6 \mathrm{a}\end{array}$ & $\begin{array}{r}13,0 \mathrm{~b} \\
20,8 \mathrm{~b} \\
58,3 \mathrm{~b} \\
530,6 \mathrm{a}\end{array}$ & $\begin{array}{r}17,0 \mathrm{~b} \\
21,9 \mathrm{~b} \\
70,6 \mathrm{~b} \\
502,7 \mathrm{a}\end{array}$ & $\begin{array}{r}138,7 \mathrm{~b} \\
237,2 \mathrm{~b} \\
356,6 \mathrm{~b} \\
2398,0 \mathrm{a}\end{array}$ \\
\hline DMS (5\%) & 13,2 & 244,8 & 110,9 & 112,6 & 66,1 & 325,7 \\
\hline $\begin{array}{l}\text { Teste F } \\
\text { C.V. (\%) }\end{array}$ & $\begin{array}{c}772,33 * \% \\
8,87\end{array}$ & $\begin{array}{l}30,25 * * \\
47,59\end{array}$ & $\begin{array}{l}40,31 * * \\
56,79\end{array}$ & $\begin{array}{l}81,39 * * \\
39,92\end{array}$ & $\begin{array}{c}205,88 * * \\
23,85\end{array}$ & $\begin{array}{c}180,60 * * \\
22,97\end{array}$ \\
\hline
\end{tabular}

$* *$ significativo a $1 \%$ de probabilidade

Tabela 66. Equações de regressão, coeficientes de determinação $\left(R^{2}\right)$, pontos de mínimo (Pm) das quantidades de zinco $(\mathrm{mg}=\mathrm{y}$ ) acumula das nas diversas partes da planta em função das idades (meses= $\mathrm{x})$.

\begin{tabular}{lcccc} 
Partes & Equaçôes \\
da planta & & $\mathrm{R}^{2}$ & \multicolumn{2}{c}{ Ponto de mínimo } \\
\cline { 4 - 5 } & & & $\mathbf{x}$ & $\mathbf{y}$ \\
\hline Folhas & $-38,7214-1,3228 x+0,0331 x^{2}$ & $99,80 * *$ & 20 & 25,5 \\
Ramos & $187,0518-7,3117 x+0,1403 x^{2}$ & $99,05 * *$ & 26 & 91,8 \\
Caule-ponta & $57,5130-3,8667 x+0,0739 x^{2}$ & $99,99 * *$ & 26 & 6,9 \\
Caule-meio & $94,9845-6,0503 x+0,1103 x^{2}$ & $99,99 * *$ & 27 & 12,0 \\
Caule-base & $72,5875-4,7042 x+0,0957 x^{2}$ & $99,97 * *$ & 25 & 14,8 \\
\hline Total & $450,4684-23,2426 x+0,4533 x^{2}$ & $99,93 * *$ & 26 & 152,5 \\
\hline
\end{tabular}


24 e 96 meses de idade para folhas de 15,1 e $20,8 \mathrm{mg}$ de $\mathrm{Zn} / \mathrm{kg}$ de folhas; 33,3 e $34,3 \mathrm{mg}$ de $\mathrm{Zn} / \mathrm{kg}$ de ramos e 13,6 e $11,0 \mathrm{mg}$ de $\mathrm{Zn} / \mathrm{kg}$ de base do caule. Por outro lado, foi observado acümulo de 15,0 e $19,0 \mathrm{mg}$ de $\mathrm{Zn} / \mathrm{kg}$ de ponta do caule e 15,0 e $16,0 \mathrm{mg}$ de $\mathrm{Zn} / \mathrm{kg}$ de meio do caule.

Aos 24 e 96 meses de idade os acúmulos estimados para quantidades de zinco em mg/planta foram 26,1 e 217,1 mg para folhas; 92,4 e 778,3 mg para ramos; 7,3 e $367,6 \mathrm{mg}$ paㅡ ra ponta do caule; 13,3 e 530,6 mg para meio do caule; 14,8 e $502,9 \mathrm{mg}$ para base do caule e 153,9 e $2396,5 \mathrm{mg}$ para planta inteira.

4.2.4. Concentração e quantidades de nutrientes acumu ladas nas diversas partes e na planta inteira em função das idades

Na Tabela 67 são apresentadas as concentrações dos macro e micronutrientes nas diversas partes da planta nas quatro idades.

Constata-se que as maiores concentraçöes de nutrientes nas partes da planta ocorrem nas folhas, exceto pa ra zinco que mostra maiores teores nos ramos em todas as idades estudadas. Quanto a concentração dos macronutrientes, ob serva-se que o nitrogênio é o elemento que apresenta os maiores teores em todas as partes, o qual juntamente com o fósforo e potássio tendem a decrescer com a idade da planta nos 


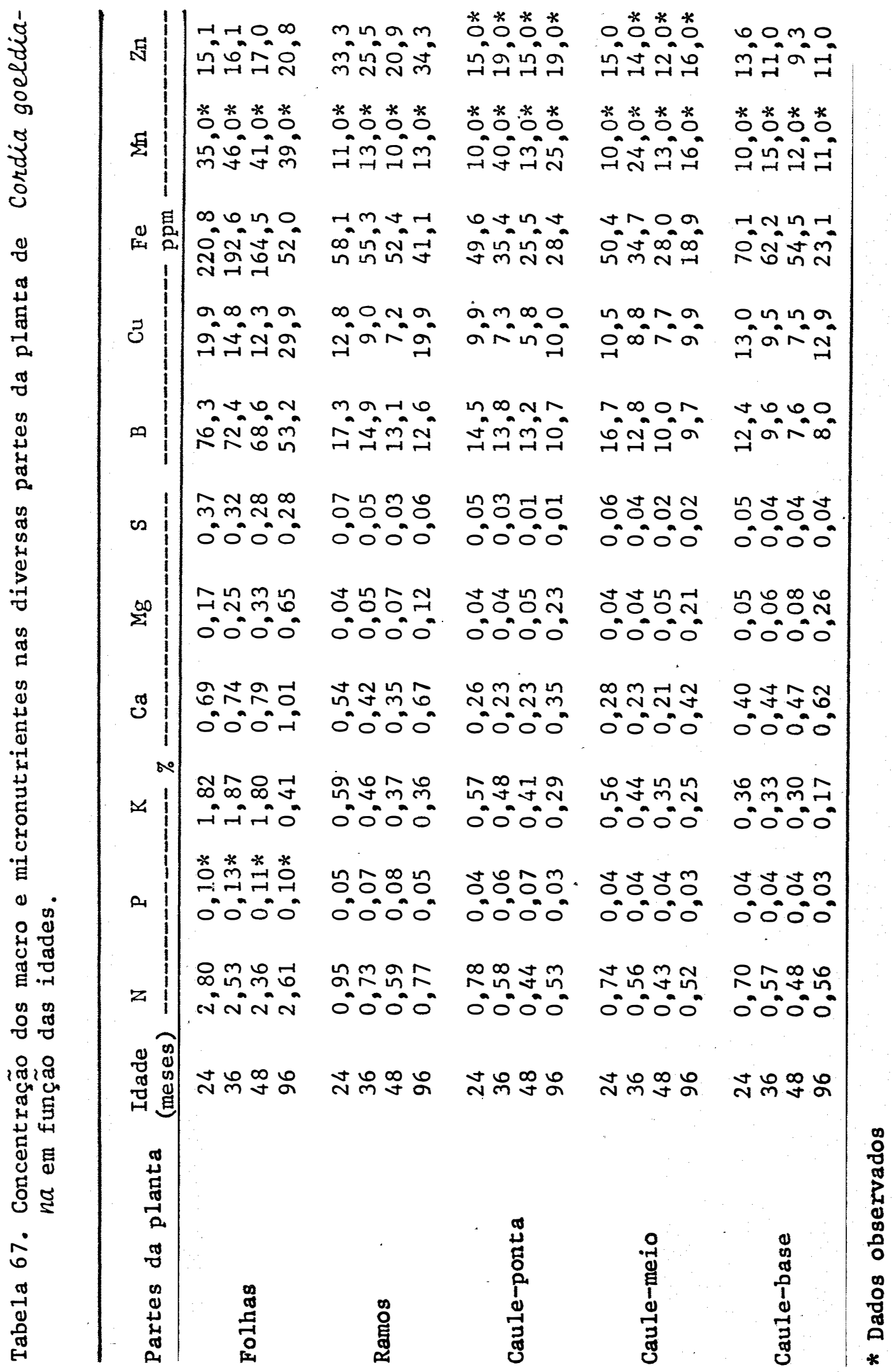


componentes, folhas, ramos, ponta, meio e base do caule. Com relação a micronutrientes verifica-se que a concentração de ferro è nitidamente superior em todas as partes, mostrandouma diminuição do teor também com a maturidade da planta.

Verifica-se quanto à ordem relativa das concentrações de nutrientes nas folhas a seqüência: nitrogênio, potássio, cálcio, magnésio, enxofre, fósforo, ferro, boro, man ganês, cobre e zinco. Os ramos apresentam a seguinte ordem: nitrogênio, cálcio, potássio, magnésio, fósforo, enxofre, fer ro, zinco, boro, cobre e manganês. Para ponta e meio do caule a seqüência: nitrogênio, potássio, cálc̈io, magnésio, fósforo, enxofre, ferro, manganês, zinco, boro e cobre. Finalmente para base do caule a seqüência: nitrogênio, cálcio, potássio, magnésio, enxofre, fósforo, ferro, manganês, zinco, cobre e boro.

Na Tabela 68 apresentam-se os dados comparativos dos teores de nutrientes em folhas de plantas adultas de Cordia goeldiana em relação a outras espécies florestais.

Verifica-se através da Tabela 68, que a Cordia goeldiana apresenta concentração de nitrogênio nas folhas bem superior aos valores observados nas espécies coníferas e folhosas exóticas, algumas folhosas nativas como Carapa guianen sis ("andiroba"), Aspidosperma polyneuron ("peroba") e a coní fera nativa Araucaria angustifolia ("pinheiro-do-paranā"), sen do que as demais mostram teores bem próximos ao da espécie estudada. 


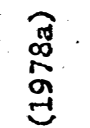

హ.

क

ซึ

苗

๖

䍃 舀昜

(4) तิ

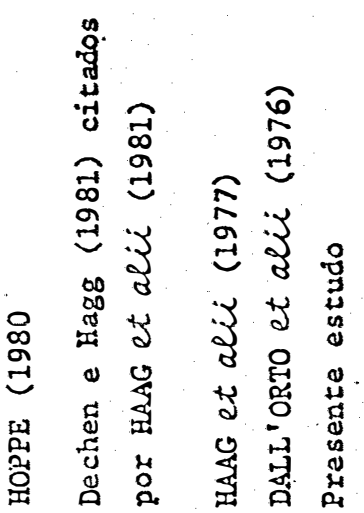

㭧

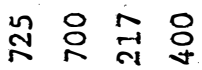

ㅇำ

a

㚙

$\exists$

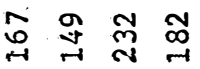

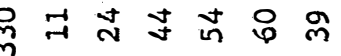

m 1 in

or $t$ in $\infty$ \%

m

즈요 1 n

N

$\frac{2}{2}$

$\underset{0}{7} \div 1 \frac{0}{0}$

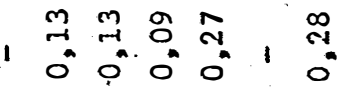

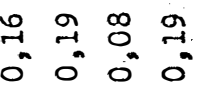

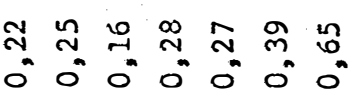

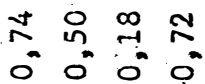

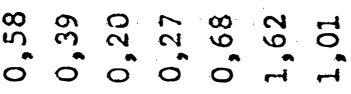

গูก

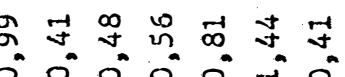

0 응

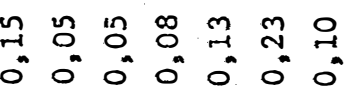

क्ष

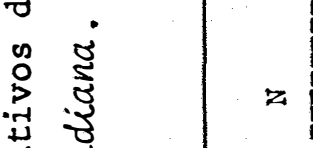

m.

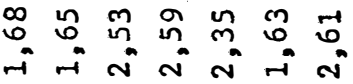

ลิ * *

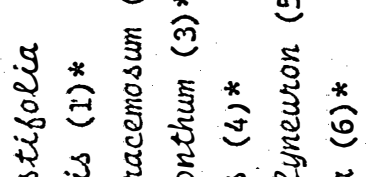

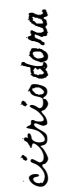

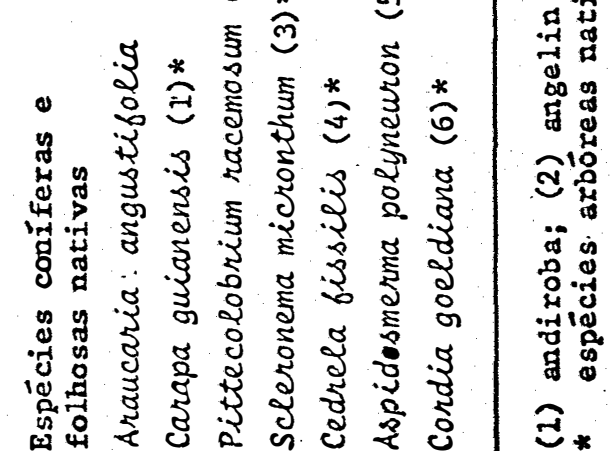

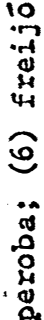

กิ

$\ddot{\circ}$

త

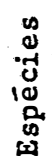

8

व

ईँ

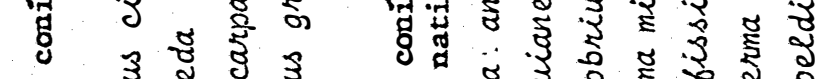

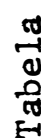

ขู ตู

. 
A concentração de $0,10 \%$ de fósforo em Cordia goeldiana é mais elevada do que as obsérvadas nas espécies na tivas, com exceçäo de cedrela fissilis ("cedro"), Aspidosper ma polyneuron e Araucaria angustifolia. Com relação as espécies exöticas apenas a concentração verificada em Eucalyptus citriodora foi igual a da Cordia goeldiana.

Confrontando os valores da concentração de potássio, observa-se que as diversas espécies mostraram teores mais elevados, excluindo Pinus taeda que mostrou concentração mais baixa e Carapa guianensis com teor similar.

Quanto a concentração de cālcio, apenas Aspidosperma polyneuron mostrou teor mais elevado quando comparado ao da Cordia goeldiana, enquanto que as demais espécies apresentaram concentrações mais baixas.

Por outro lado, verifica-se que os teores de magnèsio e enxofre em Cordia goeldiana são mais elevados quan do confrontados com aqueles observados nas diversas espécies, o mesmo acontecendo com boro e cobre.

Com relação a ferro, as concentrações das espēcies coníferas e folhosas exóticas foram bastante superiores ao da Cordia goeldiana e das espécies nativas apenas Arauca ria angustifolia, Cedrela fissilis e Aspidosperma polyneuron.

Para manganês observa-se que a Cordia goeldía na mostrou teor mais elevado somente em comparação às espécies nativas Carapa guianensis e Pithecolobrium racemosum ("an ge 1 in - rajado") 
Finalmente na Tabela 68 , constata-se que a con centração de zinco foi maior do que aquela apresentada pelas espécies exöticas Pinus oocarpa, Eucalyptus grandis e pelas nativas Carapa guianensis, Pithecolobrium racemosum e Scleronema micronthum ("cardeiro"), sendo portanto, mais baixa que as demais espécies.

A quantidade de nutrientes extraída e distribuída nas diversas partes da planta em função das idades é apresentado na Tabela 69.

Verifica-se que a quantidade de nutrientes aumenta com o incremento da matéria seca. Entretanto, este acréscimo não é diretamente proporcional, uma vez que a razão nutriente/matéria seca decresce com o aumento da idade da plan ta. Aos 24 meses de idade por exemplo, em cada quilograma de matéria seca há 31,7 g dos 11 nutrientes analisados, enquanto que aos 96 meses esta relação diminue para $19,4 \mathrm{~g} / \mathrm{kg}$ de matéria seca.

Este decréscimo pode ser justificado pela menor quantidade de matéria seca nas partes da planta com maío res teores de nutrientes (folhas e ramos) nas plantas de maior idade, associado ao rápido decréscimo da concentração da maio ria dos nutrientes.

Verifica-se que aos 24 meses de idade, a copa (folhas + ramos) representa $60,4 \%$ da matéria seca total e con tém $81,4 \%$ do nitrogênio; $82,8 \%$ do fósforo; $80,6 \%$ do potássio; $75,7 \%$ do cálcio; $63,0 \%$ do magnésio; $83,0 \%$ do enxofre; $83,8 \%$ 


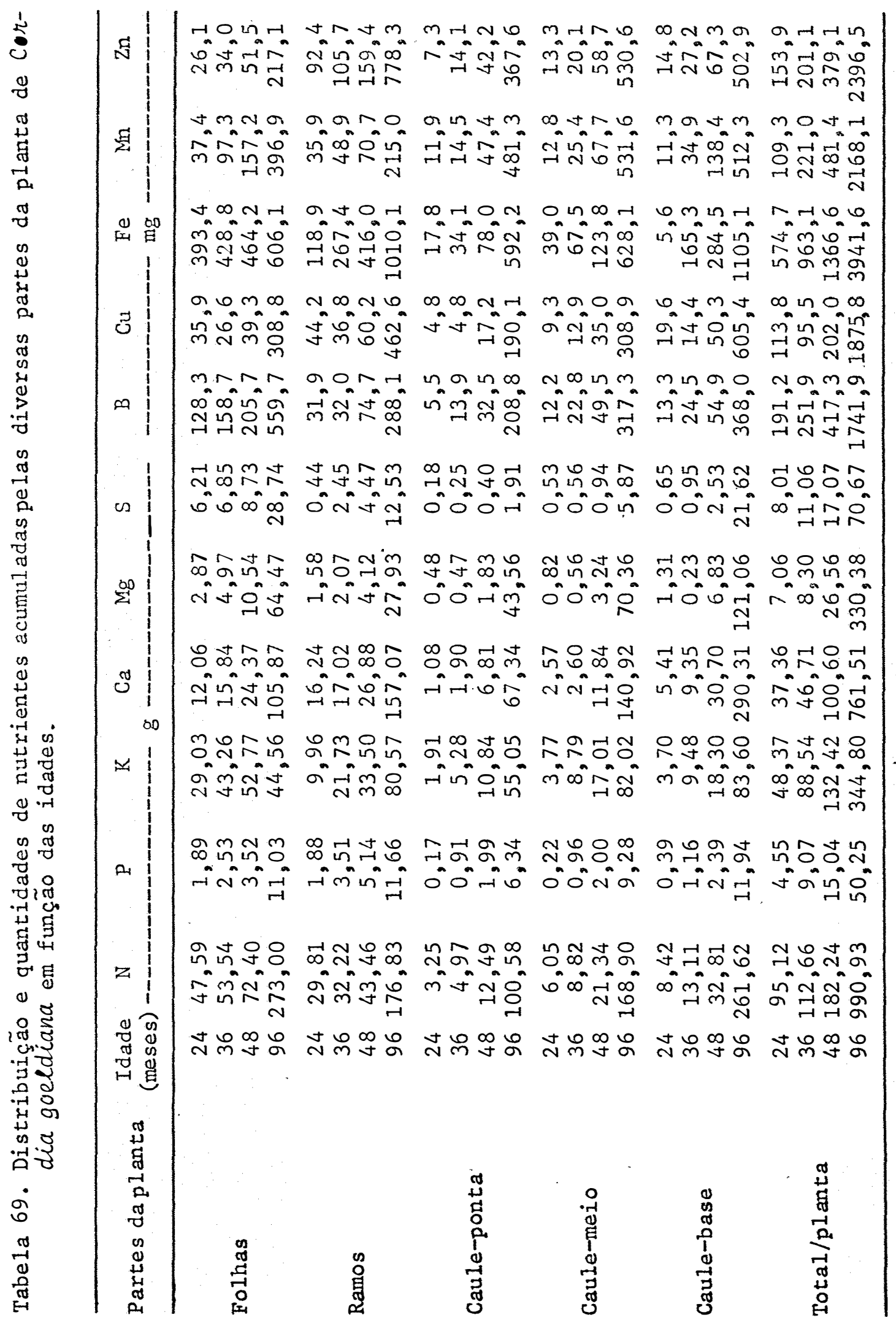


do boro; $70,4 \%$ do cobre; $89,1 \%$ do ferro; $67,1 \%$ do manganês e $77,0 \%$ do zinco acumulado na matéria seca. Por outro lado, nas plantas com 96 meses de idade, a copa representa apenas $25,5 \%$ e contém $45,4 \%$ do nitrogênio; $45,1 \%$ do fósforo; $36,0 \%$ do potássio; $34,5 \%$ do cālcio; $28,9 \%$ do magnésio; 58,4\% do enxofre; $48,7 \%$ do boro; $41,1 \%$ do cobre; $41,0 \%$ do ferro; $29,6 \%$ do manganês e $41,5 \%$ do zinco acumulado na matéria seca.

Fazendo-se uma anālise do total das quantidades de nutrientes acumuladas pelas plantas nas diversas idades estudadas, observa-se que aos 24 meses de idade a ordem decrescente de acümulo, de nutrientes foi nitrogênio, potássio, cálcio, enxofre, magnésio, fósforo, ferro, boro, zinco, cobre emanganês. Aos 36 meses a ordem foi nitrogênio, potássio, cālcio, enxofre, fósforo, magnésio, ferro, boro, manganês, zinco e cobre. Aos 48 meses a ordem foi nitrogênio, potảssio, cālcio, magnésio, enxofre, fósforo, ferro, manganês, boro, zinco e cobre. Aos 96 meses de idade a ordem decrescente foi a seguinte: nitrogênio, cälcio, potássio, magnésio, enxofre, fósforo, ferro, zinco, manganês, cobre e boro.

As quantidades de nutrientes acumuladas pela Cordia goeldiana em relação a outras espécies florestais são apresentadas na Tabela 70 com valores comparativos do acumulo de macro e micronutrientes.

Constata-se através dos dados, que a Cordia goeldiana apresenta valores de acümulo de macronutriente aos 24 meses de idade superiores aos obtidos por HAAG et alii 


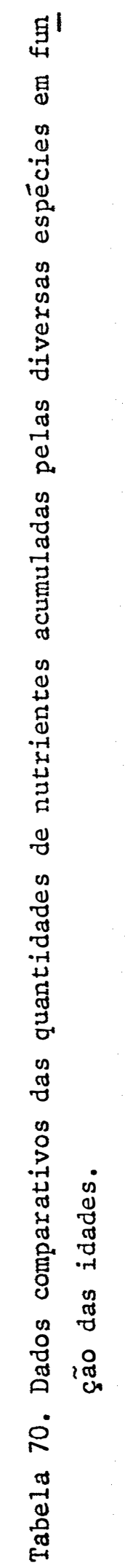

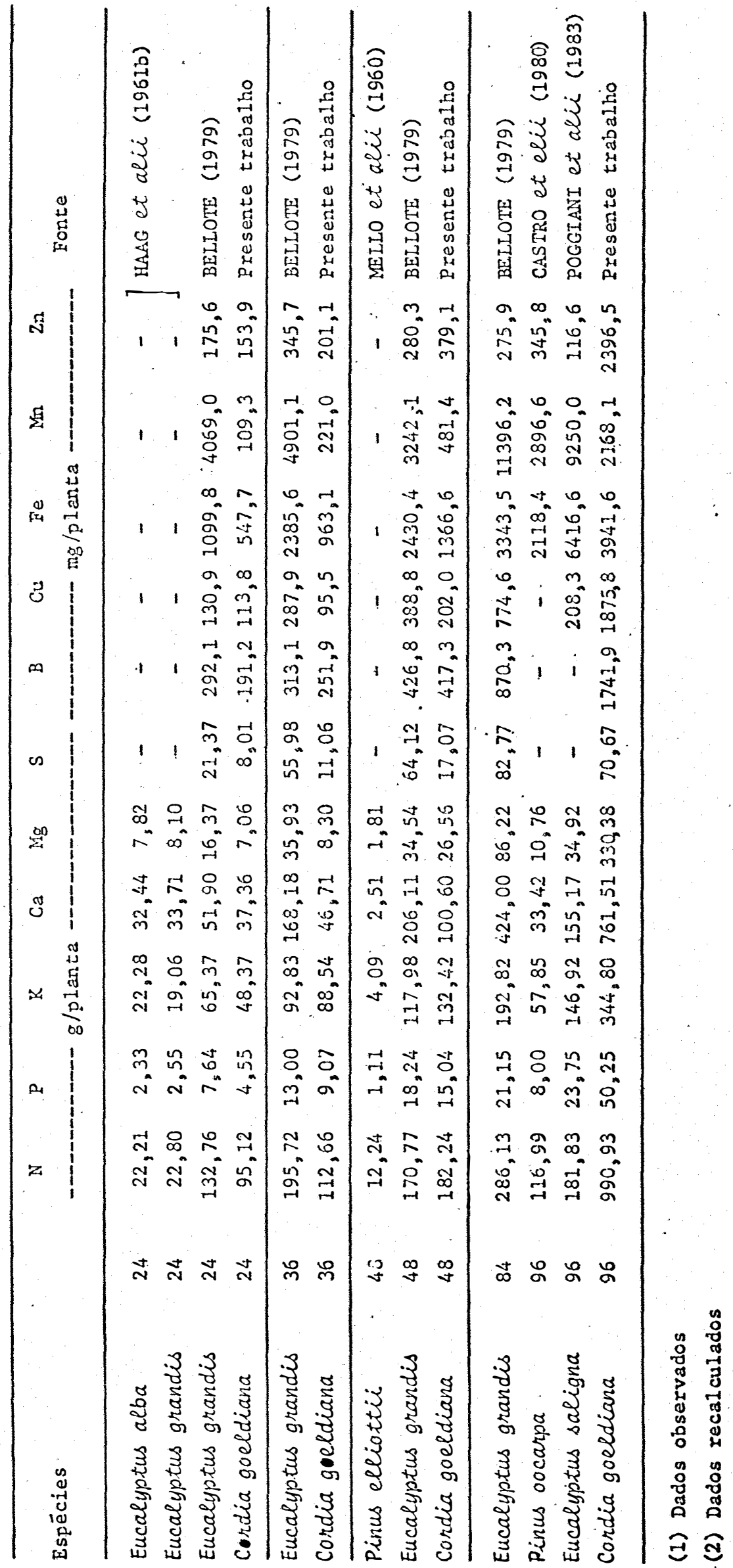


(1961b) em Eucalyptus alba e Eucalyptus grandis, porëm observa-se que as quantidades de macro e micronutrientes alcançadas por BELLOTE (1979) em Eucalyptus grandis foram maiores que as de Cordia goeldiana.

Confrontando-se as quantidades acumuladas aos 36 meses de idade, verifica-se que o Eucalyptus grandis mostrou também maior acūmulo de nutrientes.

Aos 48 meses de idade, a Cordia goeldiana mostra maiores quantidades de macronutrientes acumuladas do que Pinus elliottii, entretanto, quando comparados com os valores obtidos por BELLOTE (1979) em Eucalyptus grandis, verificase que esta espécie apresenta quantidades mais elevadas de nutrientes acumulados com exceção de nitrogênio e potássio.

Acredita-se que as diferenças observadas entre os valores de acúmulo de nutrientes em Eucalyptus grandis encontradas por BELLOTE (1979) aos 24,36 e 48 meses e Cordia goeldiana sejam em virtude das adubações empregadas, uma vez qúe aos 84 meses de idade esta diferença passa a ser a favor da espécie nativa.

Finalmente, aos 96 meses de idade, observase que a Cordia goeldiana acumula quantidades de nutrientes, bem superiores ao Pinus oocarpa, exceção feita ao manganês. Comparando-se com os valores obtidos em Eucalyptus saligna, constata-se que esta espécie mostra maiores quantidades acumuladas apenas em ferro e manganês.

A Cordia goeldiana parece mostrar, portanto, 
ser uma espécie mals exigente em nutrientes em relação as fo1hosas exóticas como Eucalyptus alba, Eucalyptus grandis e Eucalyptus saligna e as espécies exóticas como Pinus elliottii e Pinus oocarpa, quando plantadas em condições semelhan. tes.

4.2.5. Exportação de nutrientes

Na Tabela 71 encontram-se as quantidades de nutrientes e porcentagem de exportação pelo caule das plantas de Cordia goeldiana aos 96 meses de idade.

Observa-se que entre os macronutrientes, o mag nésio, cálcio e potássio foram os mais exportados do total ex traído por planta, enquanto entre os micronutrientes, foram manganês e ferro. Em porcentagem de extração, o magnésiofoi o nutriente mais exportado pelo caule, vindo a seguir em ordem decrescente manganês, cálcio, potássio, ferro, cobre, zin co, fósforo, nitrogênio, boro e enxofre. 
Tabela 71. Quantidades de nutrientes e percentagem de exportação pelo cau le de Cordia goeldiana aos 96 meses de idade.

Nutrientes $\quad$ Extração/planta $\quad \begin{aligned} & \text { \% exportada da } \\ & \text { extração total * }\end{aligned}$

\begin{tabular}{lrl}
\hline $\mathrm{N}$ & $\mathrm{g}$ & 53,4 \\
$\mathrm{P}$ & 531,10 & 54,8 \\
$\mathrm{~K}$ & 27,56 & 64,0 \\
$\mathrm{Ca}$ & 220,67 & 65,5 \\
$\mathrm{Mg}$ & 498,57 & 71,1 \\
$\mathrm{~S}$ & 234,98 & 41,6 \\
& 29,40 & \\
$\mathrm{~B}$ & $\mathrm{mg}$ & 51,3 \\
$\mathrm{Cu}$ & 894,1 & 58,9 \\
$\mathrm{Fe}$ & 1104,4 & 59,0 \\
$\mathrm{Mn}$ & 2325,4 & 70,4 \\
$\mathrm{Zn}$ & 1526,2 & 58,5 \\
\hline
\end{tabular}

* : a porcentagem exportada foi calculada através da relação quantidade de nutrientes acumuladas no caule pela quantidade total de nutriente extraído pela planta. 


\section{CONCLUSÕES}

Através das anālises e interpretações dos resultados de acordo com a metodologia empregada na presente pes quisa, pode-se concluir que:

- A produção de matéria seca total das plantas foi afetada em todos os tratamentos com omissão de nutrientes, obedecendo a seguinte ordem decrescente: nitrogênio, fósforo, cālcio, potássio, enxofre e magnésio.

- Os sintomas visuais de deficiência de nitrogênio, fósforo, potássio, cālcio, magnésio e enxofre apresentam - se bem definidos e de fácil caracteriza ção.

- As plantas apresentaram sintomas de carência quando os níveis dos elementos mostraram valores iguais e abaixo de: Nas folhas superiores - $1,03 \%$ de $N ; 0,08 \%$ de $P ; 0,33 \%$ de $K ; 0,95 \%$ de $\mathrm{Ca} ; 0,34 \%$ de $\mathrm{Mg}$ e $0,09 \%$ de $\mathrm{S}$. Nas folhas inferiores $-0,88 \%$ de $\mathrm{N} ; 0,04 \%$ de $\mathrm{P} ; 0,07 \%$ de $\mathrm{K} ; 1,66 \%$ de $\mathrm{Ca} ; 0,26 \%$ de $\mathrm{Mge} 0,10 \%$ de S. Nos ramos - 0,66\% de $N ; 0,13 \%$ de $P ; 0,36 \%$ de $K ; \quad 0,42 \%$ 
de Ca; $0,12 \%$ de $\mathrm{Mg}$ e $0,06 \%$ de S. No caule - 0,53\% de N; 0,07\% de $\mathrm{P} ; 0,40 \%$ de $\mathrm{K} ; 0,32 \%$ de $\mathrm{Ca} ; 0,09 \%$ de $\mathrm{Mg}$ e 0,04\% de $\mathrm{S}$, Nas raízes $-0,94 \%$ de $\mathrm{N} ; 0,10 \%$ de $\mathrm{P} ; 0,32 \%$ de $\mathrm{K} ; 0,43 \%$ de $\mathrm{Ca} ; 0,25 \%$ de $\mathrm{Mg}$ e $0,08 \%$ de $\mathrm{S}$.

- Os efeitos da omissão de um nutriente aumentando ou diminuindo a concentração do mesmo e dos outros nos örgãos foram os seguintes:

\begin{tabular}{|c|c|c|c|c|c|c|}
\hline $\begin{array}{l}\text { Nutr. } \\
\text { Def. }\end{array}$ & & Raízes & Caule & Ramos & $\begin{array}{c}\text { Folhas } \\
\text { inferiores }\end{array}$ & $\begin{array}{c}\text { Folhas } \\
\text { superiores }\end{array}$ \\
\hline $\mathrm{N}$ & $\begin{array}{l}\text { aumenta } \\
\text { diminui }\end{array}$ & $\mathrm{N}, \mathrm{S}$ & $\begin{array}{c}\mathrm{P}, \mathrm{Fe} \\
\mathrm{N}, \mathrm{Mg}, \mathrm{S}\end{array}$ & $\mathrm{N}^{-} \mathrm{Ca}$ & $\begin{array}{l}\mathrm{P}, \mathrm{K}, \mathrm{B}, \mathrm{Mn} \\
\quad \mathrm{N}, \mathrm{Ca}\end{array}$ & $\begin{array}{r}\mathrm{P}, \mathrm{B} \\
\mathrm{N}, \mathrm{Ca}\end{array}$ \\
\hline $\mathrm{P}$ & $\begin{array}{l}\text { aumenta } \\
\text { diminui }\end{array}$ & - & $\bar{P}$ & $\begin{array}{c}\mathrm{K} \\
\mathrm{P}, \mathrm{N}\end{array}$ & $\stackrel{\mathrm{K}}{\mathrm{P}, \mathrm{N}}$ & $\begin{array}{l}K \\
P, N\end{array}$ \\
\hline K & $\begin{array}{l}\text { aumenta } \\
\text { diminui }\end{array}$ & $\underset{\mathrm{K}}{\mathrm{S}, \mathrm{Mn}}$ & $\bar{K}, \mathrm{~B}$ & $\begin{array}{r}\mathrm{Mg} \\
\mathrm{K}, \mathrm{B}\end{array}$ & $\begin{array}{l}\mathrm{P}, \mathrm{Mg}, \mathrm{Mn} \\
\mathrm{K}, \mathrm{N}\end{array}$ & $\underset{\mathrm{K}}{\mathrm{P}, \mathrm{Ca}, \mathrm{Mg}, \mathrm{B}}$ \\
\hline $\mathrm{Ca}$ & $\begin{array}{l}\text { aumenta } \\
\text { diminui }\end{array}$ & $\begin{array}{l}\mathrm{K}, \mathrm{S}, \mathrm{Fe}, \mathrm{Mn} \\
\mathrm{Ca}\end{array}$ & $\begin{array}{c}\mathrm{K}, \mathrm{Fe} \\
\mathrm{Ca}\end{array}$ & $\begin{array}{c}\mathrm{K}, \mathrm{Fe}, \mathrm{Mn} \\
\mathrm{Ca}\end{array}$ & $\begin{array}{c}P, M g, K, S, F e, M n \\
C, N, B\end{array}$ & $\underset{\mathrm{Ca}}{\mathrm{P}, \mathrm{Mg}, \mathrm{K}, \mathrm{S}, \mathrm{B}, \mathrm{Fe}, \mathrm{Mn}}$ \\
\hline $\mathrm{Mg}$ & $\begin{array}{l}\text { aumenta } \\
\text { diminui }\end{array}$ & $\begin{array}{c}\mathrm{K}, \mathrm{S}, \mathrm{Mn} \\
\mathrm{Mg}\end{array}$ & $\begin{array}{l}\mathrm{K}, \mathrm{Mn} \\
\mathrm{Mg}, \mathrm{B}\end{array}$ & $\stackrel{\mathrm{K}}{\mathrm{Mg}, \mathrm{Ca}, \mathrm{B}}$ & $\begin{array}{c}\mathrm{P}, \mathrm{K}, \mathrm{Mn} \\
\mathrm{Mg}, \mathrm{B}\end{array}$ & $\begin{array}{c}\mathrm{P}, \mathrm{K}, \mathrm{Mn} \\
\mathrm{Mg}\end{array}$ \\
\hline$S$ & $\begin{array}{l}\text { aumenta } \\
\text { diminui }\end{array}$ & $\begin{array}{l}\mathrm{K} \\
\mathrm{S}\end{array}$ & $\begin{array}{c}\mathrm{K} \\
\mathrm{S}, \mathrm{B}, \mathrm{Cu}\end{array}$ & $\begin{array}{c}\mathrm{K} \\
\mathrm{S}, \mathrm{B}\end{array}$ & $\begin{array}{c}\mathrm{K} \\
\mathrm{S}, \mathrm{B}, \mathrm{Cu}\end{array}$ & $\begin{array}{c}\mathrm{K} \\
\mathrm{S}, \mathrm{N}, \mathrm{Cu}\end{array}$ \\
\hline
\end{tabular}

- A Cordia goeldiana é uma espécie exigente em nutrientes.

- A distribuição da matéria seca total, nas quatro idades estudadas $(24,36,48$ e 96 meses), obedece a seguinte ordem decrescente: caule (base, meio e ponta), ramos e folhas.

- Nas plantas as maiores concentrações de nu- 
trientes ocorrem nas folhas, exceto para zinco que mostra teo res mais elevados nos ramos.

- A concentração dos nutrientes nas partes da planta difere de modo a evidenciar a translocação dos mesmos no interior do vegetal.

- A ordem relativa das concentrações de nutrientes de acordo com a sequência $\mathrm{N}, \mathrm{K}, \mathrm{Ca}, \mathrm{Mg}, \mathrm{S}, \mathrm{P}, \mathrm{Fe}, \mathrm{B}, \mathrm{Mn}$, $\mathrm{Cu}, \mathrm{Zn}$ nas folhas; $\mathrm{N}, \mathrm{Ca}, \mathrm{K}, \mathrm{Mg}, \mathrm{P}, \mathrm{S}, \mathrm{Fe}, \mathrm{Zn}, \mathrm{B}, \mathrm{Cu}$, Mn nos ramos; N, K, Ca, Mg, P, S, Fe, Mn, Zn, B, Cu na ponta e meio do caule e N, Ca, K, Mg, S, P, Fe, Mn, Zn, Cu na base do cau1 e.

- A quantidade (gramas) dos nutrientes analisa dos por quilograma de matéria seca decresce em relação à idade das plantas. Esta relação è de $31,7 \mathrm{~g}$ de nutrientes aos 24 meses de idade e $19,4 \mathrm{~g}$ aos 96 meses de idade.

- Considerando a idade de maior acúmulo (96 me ses) o nitrogênio foi o macronutriente mais extraído seguido em ordem decrescente do cálcio, potássio, magnésio, enxofre e fósforo. Quanto aos micronutrientes, o elemento extraído em maior quantidade foi o ferro seguido do zinco, manganês, cobre e boro.

- Aos 96 meses de idade o magnésio é o nutrien te que apresenta maior porcentagem de exportação pelo caule, vindo a seguir em ordem decrescente manganês, cálcio, potássio, ferro, cobre, zinco, fósforo, nitrogênio, boro e enxofre. 
6. LITERATURA CITADA

AMARAL, W. do, 1983. Deficiências de macronutrientese de boro em seringueira (Hevea brasiliensis, L.). Piracicaba, ESALQ -USP. 44p. (Dissertação de Mestrado).

BALLARD, $R_{k}, 1979$. Diagnosis of fertilizer requirements of forest. In: BALLARD, R. Forest soils short course. Raleigh, NCSU. p.41-54.

BALLONI, E.A., 1979. O uso intensivo da floresta e seus reflexos na fertilidade do solo. Bol. Téc. SIF, Viçosa, 2 (nọ especial): 83-93.

BALLONI, E.A., 1984. Efeitos da fertilização mineral sobre - desenvolvimento do Pinus caribaea Morelet var.bahamensis ( $\mathrm{Gri-}$ seb) Barret et Golfari em solo de cerrado do Estado de São Pau1o. Piracicaba. $121 \mathrm{p}$. (Dissertação de Mestrado-ESALQ).

BARTOS, D.L. e K.S. JOHNSTON, R.S., 1978. Biomass and nutrient content of quaking aspen at two sites in the Western Uni ted States. Forest Science, Washington, 24(2): 283-90. 
BATAGLIA, O.C.; J.P.F. TEIXEIRA; P.R. FURLANI, A.M.C. FURLANI e J.R. GALLO, 1978. Análise quimica de plantas. Campinas, Instituto Agronômico, 31 p. (Circular, 87).

BAULE, H., 1975. World-wide use of fertilizer in forestry at present and in the near future. South African Forestry Journal, Pretoria (94): 13-9.

BELLOTE, A.F.J., 1979. Concentração, acumulação e exportação de nutrientes pelo Eucalyptus grandis (Hill ex-Maiden) em função da idade. Piracicaba, ESALQ/USP, 129p. (Disserta ção de Mestrado).

BHIMAYA, C.P. e R.N. KAUL, 1966. Levels of macro and micro elements in Eucalyptus camaldulensis Dehn ( $E$. rostrata Schlecht). Nature, London, 212: 319-320.

BRASIL SOBRINHO, M.O.C.; F.A.F. de MELLO, N. RODRIGUES e H.A. MELLO, 1961. Competição entre diferentes tipos de locali zação de adubos no plantio de Eucaliptos (Eucalyptus saZigna Smith) - Nota Prévia. In: II Conferência Mundial de Eucalipto, São Paulo, v.2, p.919-925.

BRASIL/SUDAM. Departamento de Recursos Naturais. Centro de Tecnologia Madeireira, 1979. Pesquisas e informações so bre espécies florestais da Amazônia. Belém, p.49-51.

BRIENZA JUNIOR, S., 1982a. Cordia goeldiana, Huber (Freijó) em sistema "taungya" na região do Tapajós - Estado do Pară. Belém, EMBRAPA-CPATU, 10p. (EMBRAPA-CPATU . Circular Técnica, 33).

BRIENZA JUNIOR, S., 1982b. Freijó em sistemas agroflorestais. Belém, EMBRAPA-CPATU, 15 . (EMBRAPA-CPATU. Circular Técni ca, 38). 
BRIENZA JUNIOR, S., 1982c. Programa agroflorestal da EMBRAPA /PNPF para a Amazōnia Brasileira. Belém, EMBRAPA - CPATU. 11 p. (EMBRAPA-CPATU. Documentos, 9).

BUKOVAC, M.J. e S.H. WITTWER, 1957. Absorption and mobility of foliar applied nutrients. Plant Physiol., Washington, $32: 428-435$.

CARPANEZZI, A.A., 1980. Autoecologia de Cordia goeldiana e de Cordia alliodora na Amazônia Brasileira. Belém, EM BRAPA-CPATU. 3p. (EMBRAPA-CPATU. Comunicado Técnico, 31).

CARPANEZZI, A.A. e J.A.G. YARED, 1981. Crescimento de freijó (Cordia goeldiana, Huber) em plantiosexperimentais. Belém, EMBRAPA-CPATU. 10p. (EMBRAPA-CPATU. Boletim de Pesquisa, 26).

CARPANEZZI, A.A.; J.A.G. YARED; S. BRIENZA JUNIOR; L.C.T. MAR QUES e J. do C.A. LOPES, 1983. Regeneração artificial de freijó (Cordia goeldiana, Huber). Belém, EMBRAPA - cPATU. $21 \mathrm{p}$. (EMBRAPA-CPATU. Circular Técnica, 39).

CARPANEZZI, A.A. e M. KANASHIRO, 1982. Informações sobre a ecologia do freijó-cinza (Cordia goeldiana, Huber). Be1ém. EMBRAPA-cPATU. 13p. (EMBRAPA-CPATU. Documentos, 14 ).

CASTRO, C.F.A.; F. POGGIANI e N. NICOLIELO, 1980. Distribui ção da fitomassa e nutrientes em talhões de Pinus oocarpa com diferentes idades. IPEF, Piracicaba, (20):61-74.

CATANI, R.A. e A.O. JACINTHO, 1974. Avaliação da fertilidade do solo: métodos de anālises. Piracicaba, ESALQ/USP. $61 \mathrm{p}$. 
CIBES, H. e G. SAMUELS, 1955. Mineral deficiency symptoms dis played by coffee trees under controled conditions. Agric. Exp. Sta. Un. Puerto Rico. Rio Piedras. Technical Paper $14(8)$.

CLELAND, R. , 1960. Effect of auxin upon loss of calcium from cell walls. Plant Physiol., Washington, 35: 581-584.

CROW, T.R. e R.W. BLANK, 1978. Distribution of biomass and production for several northern woody species. North Central Forest Experimental Station, Research Note NC-239. $33 \mathrm{p}$.

CURLIN, J.W., 1970. Nutrient cycling as a factor in site productivity and forest fertilization. In: YOUNGBERG, C.T. and DAVEY, C.B. Ed. Tree growth and forest soils. Oregon, Oregon State University Press. p.313-326.

DALL'ORTO, F.A.C.; R.C.D. GARLIPP; J.L. BRAUNER e M.T. de MIRANDA, 1976. Concentraçoes de alguns macro e micronutrientes em essências florestais do Parque da Escola Superior de Agricultura "Luiz de Queiroz". Anais da E.S.A. "Luiz de Queiroz", Piracicaba, 33: 233-242.

DOI, S.; S. BARROS SILVA; H. de C. FERREIRA; L. GOES FILHO; F. de J.F. COELHO e E.F. de M. TEREZO, 1975 . Folha NA 21 Tumucumaque e parte da NB 21 - IV. Vegetação. As regiões fitoecológicas, sua natureza e seus recursos econômicos; estudo fitogeográfico. In: BRASIL. Ministério das Minas e Energia. Departamento Nacional de Produção Mineral. Proje to RADAMBRASIL. Folha NA 21 Tumucumaque e parte da foIha NB 21. Rio de Janeiro. p.264-6,299-330 (Levantamento de Recursos Naturais, 9). 
EGUNJOBI,J.K. e S.O. BADA, 1979. Biomass and nutrient distri bution in stands of Pinus caribaea L. in the dry forest zone of Nigeria. Biotropica, Fairfax, 11(2): 130-5.

EMPRESA BRASILEIRA DE PESQUISA AGROPECUARIA/INSTITUTO BRASILEIRO. DE DESENVOLVIMENTO FLORESTAL, 1984 a. Programa Nacional de Pesquisas de Florestas, Curitiba, $42 \mathrm{p}$.

EMPRESA BRASILEIRA DE PESQUISA AGROPECUARIA/INSTITUTO BRASILEIRO DE DESENVOLVIMENTO FLORESTAL, 1984b. Relatório Téc nico do Programa Nacional de Pesquisa Florestal, período 1982-1983. Brasília. 88p.

EPSTEIN, E., 1975. Nutrição mineral das plantas: princípios e pespectivas. Rio de Janeiro, Livros Técnicos e Cientí ficos. $341 \mathrm{p}$.

EVANS, J., 1979. The effects of leaf position and leaf age in foliar analysis of Gmelina arborea. Plant and Soil, The Hague, 52(4): 547-552.

FASSEL, V.A., 1979. Simultaneous or sequential determination of the elements at all concentration levels - the renaissance of and old approach. Analytical Chemistry, 5(13).

FORREST, W.G. e J.D. OVINGTON, 1970. Organic matter changes in age series of Pinus radiata plantations. Journal Applied Ecology, 7: 177-80.

FORREST, W.G. e J.D. OVINGTON, 1971. Variation in dry weight and mineral nutrient content of Pinus radiata progeny. Silvae Genetica, Frankfurt, 20(5/6): 174-9. 
FOWELLS, H.A. e R.W. KRAUSS, 1959. The inorganic nutrition of Loblolly Pine and Virginia Pine with special reference to nitrogen and phosphorus. Forest Science, 5: 95-112.

FRAZT̃O, D.A.C., 1983. Efeitos dos elementos e suas deficiên cias. In: HAAG et alii. Nutrição e Adubação da Seringuei ra no Brasil. Campinas, Fundação Cargil, 116 .

GILBERT, F.A., 1951. The place of sulfur in plant nutrition. The Bot. Rev., 17(9): 671-691.

GONZALES ESPARCIA, E. e J.J. GARCIA NUÑO, 1964. Some aspects of $N$ nutrition in Eucalipt seedling. Ann. Inst. For. Invest. Exp., Madrid, 36(9): 81-101.

HAAG, H.P., 1958. Efeitos das deficiências e excessos de macronutrientes no crescimento e na composição do cafeeiro (Cobfea arabica L. var. Bourbon (B. Roch.) Chouss) cultivado em solução nutritiva. Piracicaba, SP, ESALQ/USP. , 103p. (Tese de Doutoramento).

HAAG, H.P.; A.N. GONÇALVES; Z. TENORIO e U.A. TENORIO, 1981. Distürbios nutricionais em Gmelina arborea. o Solo, Piracicaba, $73(2): 33-8$.

HAAG, H.P.; F.A.F. de MELLO; M.O.C. BRASIL SOBRINHO; W.R. ACCORSI; E. MALAVOLTA e S. ARZOLLA, 1961a. Estudos sobre a alimentação mineral do eucalipto: sintomas das deficiências dos macronutrientes e composição mineral. In: II Conferência Mundial do Eucalipto, São Paulo, v.2., p.926932 .

HAAG, H.P.; H.A. MELLO; F.A.F. de MELLO; M.O.C. BRASIL SOBRINHO e A.A. VEIGA, 1961b. Composição quimica de Eucalyptus alba Reinw e Eucalgptus grandis (Hil1) Maiden : resultados preliminares. In: I I Conferência Mundial do Eucalipto, São Paulo, v. 2, p. 1329-34. 
HAAG, H.P.; J.R. SARRUGE; G.D. de OLIVEIRA; F. POGgIANI e C.A. FERREIRA, 1976. Análise foliar em cinco espécies de Eucalyp tus. IPEF, Piracicaba (13): 99-116.

HAAG, H.P.; J.W. SIMÕes; G.D. de OLIVEIRA; J.R. SARRuge e F. POGGIANI, 1977. Distürbios nutricionais em Eucalyptus citriodora. IPEF, Piracicaba (14): 59-68.

HAAG, H.P.; J.V. de C. ROCHA FIlHo e G.D. de OLIVEIRA, 1978. Ciclagem de nutrientes em florestas implantadas de Eucalyptus e Pinus. II. Contribuição das espécies de nutrien tes na manta. O Solo, Piracicaba, 70(2):28-31.

HEWITT, E.J., 1951. Role of the mineral elements in plant nu trition. Ann. Rev. P1ant Physiology, 11: 25-52.

HOAGLAND, D.R., 1948. Lectures on the inorganic nutrition of plants. 2a ed. Waltham, Massachussets, Chronica Botânica Company, $226 \mathrm{p}$.

HOPPE, J., 1980. Correlações entre condições edáficas e o crescimento da Araucaria angustifolia na flora de Passo Fundo, RS. Curitiba (Dissertação de Mestrado - UFP).

JONES, H.E. e G.D. SCARSETH, 1944. The calcium-boron balance in plants as related to boron needs. Soil Science, 57: $15-24$.

JORDAN, H.V. e L.E. ENSMINGER, 1958. The role of sulfur in soil fertility. Advances in Agronomy, New York, 10: 40734 .

KAUL, O.N.; P.B.L. SRIVASTAVA e H.M. MATHUR, 1966. Nutrition studies on Eucalyptus. II. N, P, K requirements of Eucalyptus hybrid seedlings. Indian Forestry, 92(12): 772-778. 
KAUL, O.N.; P.B.L. SRIVASTAVA e V.N. TANDON, 1968. Nutrition studies on Eucalyptus. III. Diagnosis of mineral deficien cies in $E$. grandis seedlings. Indian Forestry, 94 (11): 831-834.

KILMER, V..J. e L.T. ALEXANDER, 1949. Method of making mechanical analysis of soils. Soil science, Baltimore, 68 : $12-26$.

KING, K.F.S., 1968. Agri-silviculture. Ibadan, University of Ibadan, Department of Forestry. 109 p.

KRAMER, P.J. e I.I. KOSLOWSKI, 1960. Mineral nutrition and salt absorption. In: Physiology of trees. New York, McGraw-Hill Book Co. Inc. p.224-75.642p.

LINGLE, J.C.; L.0. TIFFIN e J.C. BROWN, 1963. Iron uptake transport of soybeans as influenced by other cations. Plant Physiology, Lancaster, 38: 71-76.

LUHNIS, M.P., 1960. Effect of magnesium and calcium supplyon the uptake of manganese by various crop plants. Plant and Soil, The Hague, 12: 339-376.

LUCAS, R.E. e G.D. SCARSETH, 1947. Potassium, calcium and magnesium balance and reciprocal relationship in plants. J. Amer. Soc. Agron., 39: 887-897.

MACHICADO, M. e D. BOYNTON, 1961. Effects of K, Mg and Ca de ficiences on the intermediary $N$ constituints of cocoa lea ves. Proc. Amer. Soc. Hort. Sci., 77: 231-235.

MADGWICK, H.A.I., 1976. Mensuration of forest biomass. In: Oslo Biomass Studies. Orono, University of Maine. p.13-27. 
MAINIERI, C., 1958. Identificação das principais madeiras do comércio no Brasil. São Paulo, Instituto de Pesquisas Tec nológicas, 189p. (IPT. Boletim 46).

MALAVOLTA, E., 1963. Cultura e adubação do cafeeiro. São Pau 10, Instituto Brasileiro de Potassa. 277 .

MALAVOLTA, E., 1977. O potássio e a planta. Boletim Técnico. Instituto da Potassa e Fosfato. Piracicaba, (1) 60 .

MALAVOLTA, E.; H.P. HAAG; F.A.F. de MEllo e M.O.C. BRASIL SOBRINHO, 1974. Nutrição mineral e adubação das plantas cultivadas. São Paulo, Ed. Pioneira. 727 .

MALAVOLTA, E.; H.P. HAAG; J.R. SARRUGE e R. VENCOVSKY, 1964 . Influência do nitrogênio, fósforo e potássio no crescimen to e composição química do Pinus elliottii Engelmann culti vado em solução nutritiva. Silvicultura em São Paulo, 3 : $115-128$.

MALAVOLTA, E.; J.R. SARRUGE; H.P. HAAG; R: VENCOVSKY; C.F.o. SANTOS; O. VALSECHI; L.C. SCOTON e R.S.G. COELHO, 1970. The relation of the concentracion of macronutrients in the substrate and in the foliage to cell was thickness and cellulose concentration in the xylem of slash pine (Pinus elliottii). Anais da E.S.A. "Luiz de Queiroz", Piracica ba, 27: 295-333.

MASCARENHAS, H.A.A., 1977. Cálcio, enxofre e ferro no solo e na planta. Fundação Cargill. 95 p.

MASS, E.V.; D.P. MOORE e B.J. MASON, 1969. Influence of calcium and magnesium on manganese absorption. Plant Physiology, Lancaster, 44: 796-800.

MELLO, H.A.; A.A. VEIGA; F.A.F. de MELLO; M.O.C. BRASIL SOBRI NHO; H.P. HAAG e E. MALAVOLTA, 1960. Composição de Pinus elliottii Engelmann. Fertilité, Paris, 9: 11-4, 
MELLO, F.A.F. de; M.O.C. BRASIL SOBRINHO; H.A. MELLO;A.A. VEI GA e S. ARZOLLA, 1961. Efeitos da adubação nitrogenada, fosfatada e potássica sobre o "stand" em Eucalyptus (Eucalyptus alba Reiwn). In: II Conferência Mundial do Eucalipto. São Paulo, v.2, p.933-37.

MENGEL, K. e E.A. KIRKBY, 1978. Principles of pliat mutrition. Berne, International Potash Institute, 593 .

* MEngel, K.; M. VIRO e G. HEHL, 1976. Effect of potassium un uptake and incorporation of ammonium-nitrogen of rice plants. Plant and Soil, 44: 547-558.

MENGEL, K. e T. ASKAI, 1954. The potassium concentrations of the soil solution and its effect on the yields of spring wheat. Soil Science, 77: 419-426.

METRO, A.E. e G. BEAUCORPS, 1958. Influência dos povoamentos de Eucalipto sobre a evolução dos solos arenosos do RHARB. Fertilité, 4: 3-13.

MUHR, G.R., 1942. Plant symptoms of boron deficiency and effects of borax on the yield and chemical several crops. Soil science, 54: 55.

NIELSEN, W.A. e C. PALZER, 1977. Analysis of foliar samples of healthy and dieback. Eucalyptus obliqua. Australian Forestry, $\$ 0(3): 219-222$.

OVERSTREET, R.; L. JACOBSON e R. HANDLEY, 1952. The effects of $\mathrm{Ca}$ on the absorption of $\mathrm{K}$ by barley. Plant Physiology, Lan caster, 27: 583-590. 
OVINGTON, J.D. e H.A.L. MADGWICK, 1959. Distribution of organic matter and plant nutrients in a plantation of scots Pine. Forest science, Washington, 5(4): 344-55.

PIO CORREA, M., 1952. Dicionärios das plantas üteis do Brasil e. das exóticas cultivadas. Rio de Janeiro, Ministério da Agricultura, Serviço de Informação Agrícola. v. III. p. $311-312$.

PIMENTEL GOMES, F., 1973. Curso de estatística experimental. 7 ạ ed. São Paulo, Livraria Nobel S.A. 430 .

POGGIANI, F.; H.T.Z. do COUTO e J.W. SIMÕES, 1979 . Aspectos e co1ógicos das mini-rotações e do aproveitamento dos resíduos florestais. Circular Técnica, IPEF, Piracicaba (74): $1-7$.

POGGIANI, F.; H.T.Z. doCOUTO; L. CORRADINI e E.C.M.FAZZUO, 1983. Exportação de biomassa e ntutrientes através da explotação dos troncos e das copas de um povoamento de Eucalyptus saligna. IPEF, Piracicaba (25): 37-39.

POGGIANI, F.; H.T.Z. doCOUTO e W. SUITER FILHO, 1980. Biomas and nutrient estimates removal in short rotation intensively cultured plantation of Eucalyptus grandis. Āguas de São Pedro, IUfRO. $11 \mathrm{p}$.

PRITCHETT, W.L., 1979. Properties and managemt of forest soils. New York, John Wiley \& Sons. 500 p.

RASMUSSEN, H.P., 1967. Calcium and strenght of leaves. I. Anatomy and histochemistry. Bot. Gaz., 128: 219-223.

REEVE, E. e J.W. SHIVE, 1944. Potassium-boron and calcium relationships in plants nutrition. Soil Science, 57: 1-14. 
RICHARDS, E.J. e E. BERNER, 1954. Physiological studies in plant nutrition. XVII. A general survey of the free aminoacids of barley as affected by mineral nutrition with special reference to potassium supply. Annals of Botany, London, 18: 15-33.

RIZZINI, C.T., 1971. Arvores e Paulo, E. B1Ucher. 292 p.

ROCHA FILHO, J.V. de C.; H.P. HAAG; G.D. de OLIVEIRA e R.A. PITELLI, 1978a. Ciclagem de nutrientes em florestas implantadas de Eucalyptus e Pinus, distribuição no solo e na manta. Anais da E.S.A. "Luiz de Queiroz", Piracicaba, SP., 35: 113-123.

ROCHA EILHO, J.V. de C.; H.P. HAAG e G.D. de OLIVEIRA, 1978 . Deficiência de macronutrientes, boro e ferro em Eucalyptus urophylla. Anais da E.S.A. "Luiz de Queiroz", Piracicaba, SP, 35: 19-34.

RODRIGUES, I.A., 1982. Informações botânicas sobre

Cordia goeldiana, Huber. Belēm, EMBRAPA-CPATU. 4p. (EMBRAPACPATU. Comunicado Técnico, 36).

SARRUGE, J.R., 1968. Estudo sobre as relações cálcio-boro e potássio-boro no cafeeiro (Cofbea arabica L. var. Mundo Novo). Piracicaba, ESALQ/USP (Tese de Doutoramento).

SARRUGE, J.R., 1975. Soluções nutritivas. Summa Phytopatholo gica, Piracicaba, 1: 231-233.

SARRUGE, J.R. e H.P. HAAG, 1974. Análise química em plantas. Piracicaba, ESALQ/USP. $56 \mathrm{p}$. 
SILVA, M.F., 1977. Nomes vulgares de plantas anazônicas. Belém, INPA. $22 \mathrm{p}$. ilust.

SILVA, H.D. da, 1983. Biomassa e aspectos nutricionais de cinco espēcies do gênero Eucalyptus, plantadas em solo de baixa. fertilidade. Piracicaba. 9lp. (Dissertação de Mes trado - ESALQ).

SIMÕES, J.W., 1973. Efeitos da omissão de nutrientes na ali mentação mineral do pinheiro do Parana.. Araucaria angustí 6lia (Bert.) 0. Itze. cultivado em vaso. In: II Congresso Florestal Brasileiro, Curitiba, Anais. Curitiba, FIEP. p. $112-21$.

SINGH, B., 1982. Nutrient content of standing crop and biolo gical cycling in Pinus patula ecosystem. Forest Ecology and Management, 4: 317-32.

SHORROCKS, V.M., 1964. Mineral deficiences in hevea and asso ciated cover plants. Rubber, Res. Inst. Malaya. 76p.

SHORROCKS, V.M., 1965. Mineral nutrition growth and nutrient cycle of Hevea brasiliensis. I. Growth and nutrient content. Journal of the Rubber Research Institute of Malaya, $19: 32-47$.

SHOULDERS, E. , 1981. Concentration and distribution of selec ted elements in above-ground biomass of 8-year-old slashPine. General Technical Report 50-34. New Orleans, Southern Forest Experimental Station: 254-58.

SLOOTEN, H.J. van der; C.D.J. LISBOA; M. SOBRAL FILHO e F. PASTORE JUNIOR, 1976. Espécies florestais da Amazônia características, propriedades e dados de engenharia da ma deira. Brasília, IBDF-PRODEPEF. 90p. (PRODEPEF. Série Técnica,6). 
SUCOFF, E.I., 1961. Potassium, magnesium and calcium deficiency symptoms of Loblolly and Virginia Pine seedlings. Sta. Pap. Ntheast. For. Exp. Sta. No., 164. 18p. In: Forestry Abstracts, 23 no 5325.

SWITZER, G.L. e L.E. NELSON, 1972. Nutrient accumulation and cicling in Loblolly Pine (Pinus taeda L.). Plantations Eco systems: The first twenty years. Soil Science Society American Proce edings, Madison, 36(1): 143-7.

SWItZER, G.L.; L.E. NELSON e W.H. SMIth, 1968. The mineral cycle in forest stands. In: Forest Fertilization: theory and pratice. Knoxville, Tennessee Valley Authority. p.1-9.

TABATABAI, M.A. e J.M. BREMnER, 1970. A simple tubiaimetric method of determining total sulfur in plant materials. Agron. J., 62: 805-806.

TAMM, C.0., 1964. Determinations of nutrient requirements of forest stands. In: ROMBERGER, J.A. and MIKOLA, P. International review of forest research. New York, Academic Press. p.115-59.

TARAS, M.A., 1978. Biomass of Souther Pines and their product yields. In: Complete Tree Utilization of Southern Pine. Wisconsin, Forest Products Research Society. p.15-23.

THOMAZ, M.D.; R.H. HENDRICKS e G.R. HILL, 1950. Sulfur content of vegetation. Soil Science, 70(1): 9-17.

ULRICH, A. e K. OHKI, 1966. Potassium. In: H.D. Chapman (ed.) . Diagnostic criteria for plants and soils. Univ. California, Div. of Agricultural Sciences. p.362-393. 
VILLALOBOS-DOMINGUES, C. e VILLALOBOS, J., 1947. Atlas de los colores. Libréria El Ateneo, Buenos Aires, Argentina. $147 \mathrm{p}$.

WHITACKER, R.H. , 1975. Communities and ecosystems. 2a. ed, New Iork, MacMillan Publishing Company. 385 .

WILL, G.M., 1961a. Some notes on nutrient deficiency Eucalyptus spp. In: II Conferência kundial do Eucalipto, São Paulo, vol. $2.938-941$.

WILL, G.M., 1961b. The mineral requirements of Radiata Pine seedlings. N.Z.J. Agric. Res. 4(3/4), (309-27). In: Forest. Abstracts, 23 No 3738 .

YARED, J.A.G., 1983. Comportamento e variabilidade de procedências de Cordia alliodora (Ruiz \& Pav.) oken, no planal to do Tapajós - Belterra - PA. Piracicaba. 109p. (Disser tação de Mestrado - ESALQ).

YARED, J.A.G. e A.A. CARPANEZZI, 1981. Conversão da capoeira alta da Amazônia em povoamento de produção madeireira: 0 método do "recru" e espécies promissoras. Brasil Florestal, Brasília, $9(45): 57-73$.

YARED, J.A.G.; A.A. CARPANEZZI e A.P. CARVALHO FILHO, 1980. Ensaio de espécies florestais no planalto do Tapajós. Belém, EMBRAPA-CPATU. 22p. (EMBRAPA-CPATU. Boletim de Pesquisa, 11 ).

ZAKIA, M.J.B.; F. POGGIANI e H.T.Z. do COUTO, 1983. Correlação entre a concentração de nutrientes nas copas e a altu ra das ärvores de eucalipto plantadas em povoamentos puros. IPEF, Piracicaba, (25): 29-32. 
ZEN, S.; F. POGGIANI e H.T.Z. do COUTO, 1981. Variação da concentração de nutrientes ao longo do caule de Eucalyptus saligna: implicações na utilização energética dos resíduos florestais. Circular Técnica. IPEF, Piracicaba, (136): 1-7. 